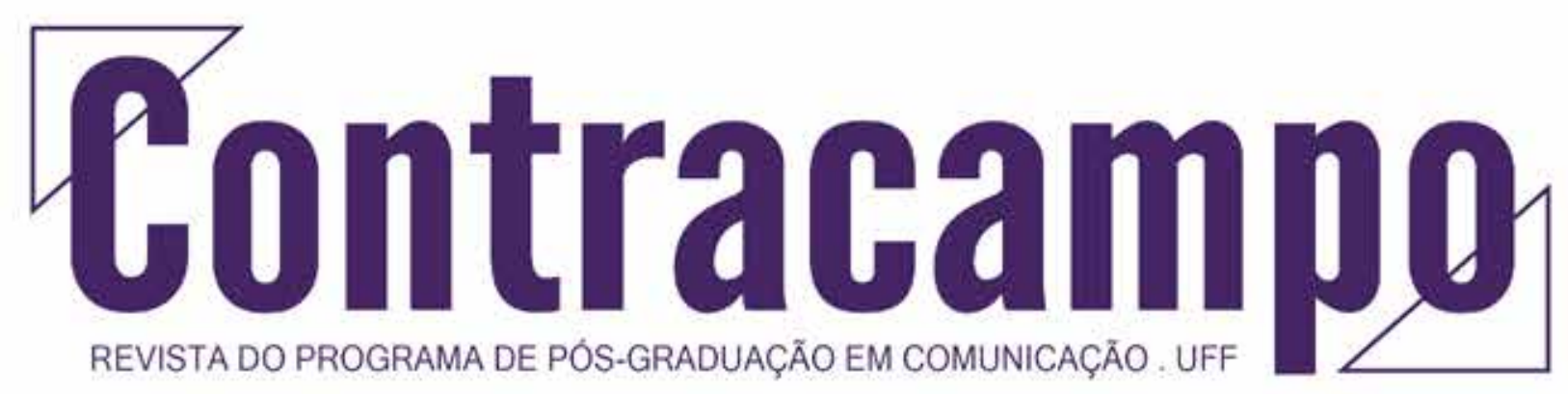

VOLUME 35 - NÚMERO 3 - 2016/17 - E-ISSN 2238-2577 · DEZ-MAR

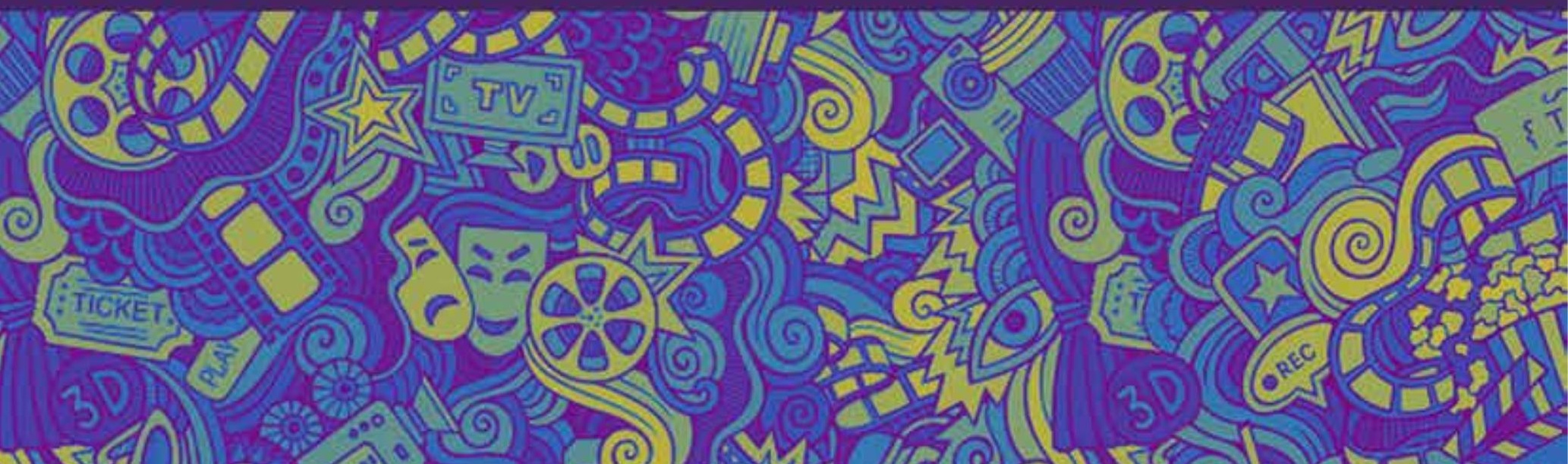

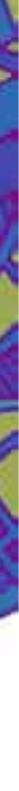
(อ) (9)

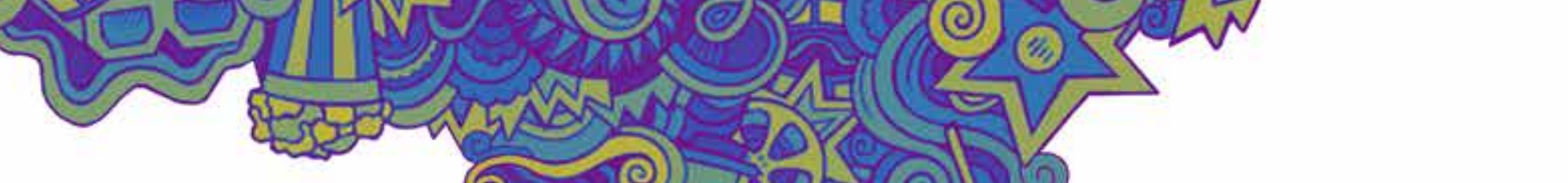

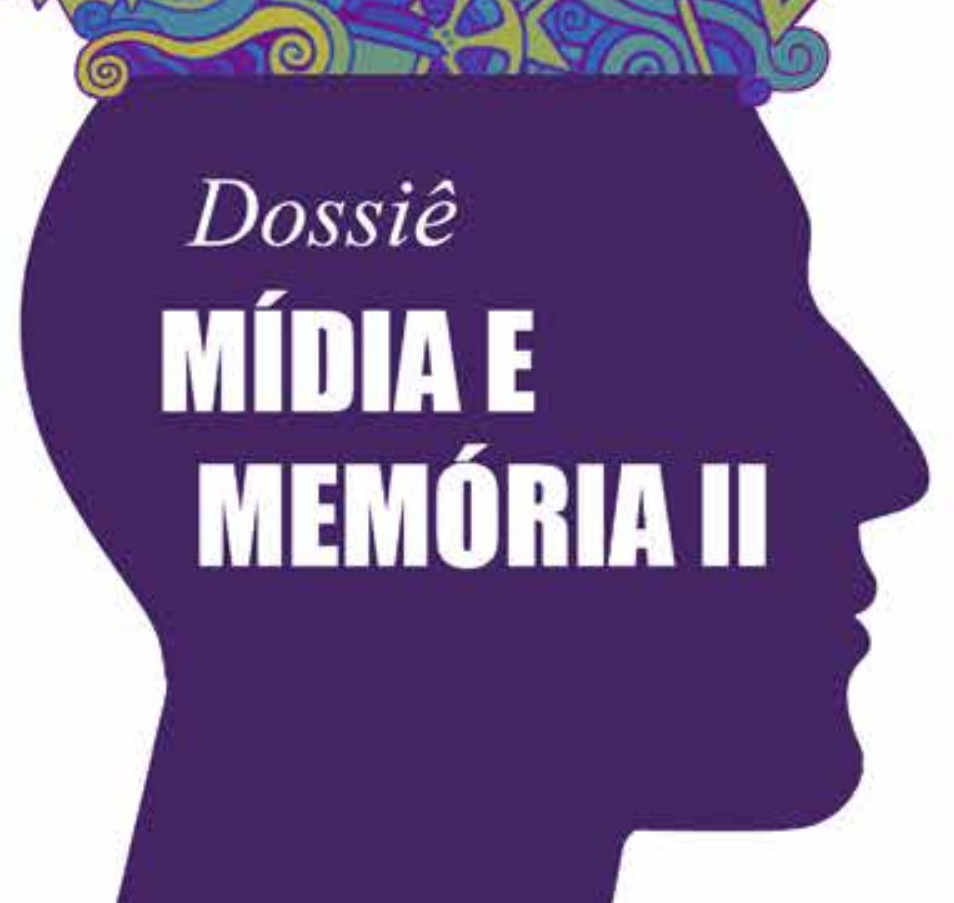




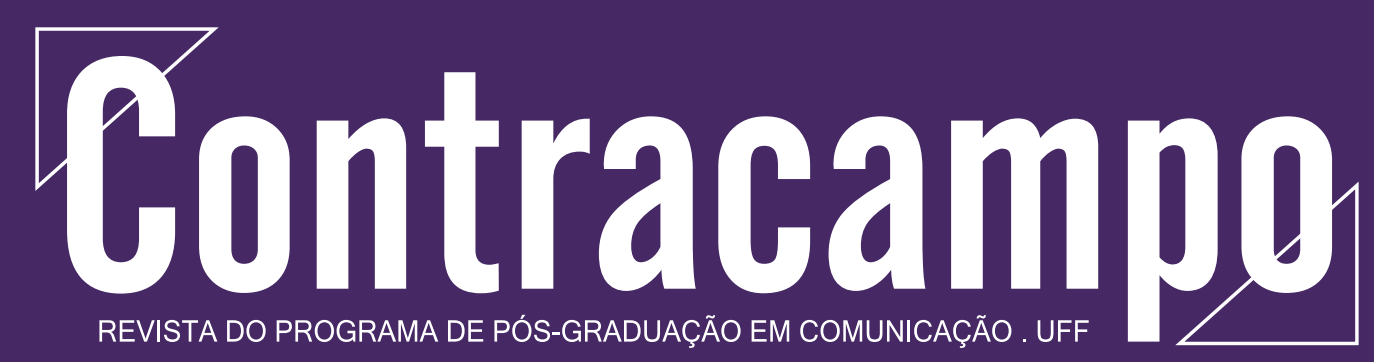

\section{Editorial vol. 35 n.3 Revista Contracampo}

\section{Caros leitores,}

Esta edição da Revista Contracampo traz o segundo volume do dossiê sobre Mídia e Memória, com 11 artigos de pesquisadores de diversas instituições do país dedicados ao tema. Dentre os trabalhos há aproximações com perspectivas históricas, jornalísticas, publicitárias, cinematográficas e artísticas, demonstrando a pluralidade de campos que são atravessados pelos diferentes dispositivos midiáticos e distintas fundamentações teóricas sobre as noções de memória.

Dando início ao dossiê a autora Letícia Matheus (UERJ) investiga, em "A imprensa dos subúrbios (1900-1920)", como certas ideias do que seria o subúrbio carioca foram construídas e narradas pelo jornalismo impresso naqueles anos. Em seguida, Lucia Santa Cruz (ESPMRJ) problematiza, em "Os relevos da memória", como instituições jornalísticas como $O$ Globo e $O$ Estado de São Paulo podem, através de seus projetos memorialísticos, fomentar uma discussão sobre os próprios valores de atualidade e noticiabilidade do jornalismo, para além de funcionarem como marcadores de preservação e resgate histórico.

Ainda no campo do jornalismo, mas passando para ambientes virtuais, Ana Paula Goulart Ribeiro e Rachel Bertol (UFRJ) vão propor, em "Memórias em disputa na cobertura do caso Snowden: A reinvenção da autoridade jornalística na era digital" que a contemporaneidade, a partir principalmente da potência memorialística tida como sem falhas das tecnologias da informação e comunicação, vai proporcionar um jogo de inversão dos valores do jornalismo moderno. Seguindo reflexões relevantes sobre o universo virtual, Maria Clara Aquino (Unisinos) traz uma análise de como a plataforma @BRnasRuas corrobora para uma 
construção de memória coletiva sobre as manifestações de junho de 2013 no país.

Adentrando o universo da ficção televisiva, Robéria Nascimento (UEPB) vai analisar a minissérie Tenda dos Milagres, baseada em obra de Jorge Amado, enquanto possibilidade de construção de uma memória social sobre pessoas negras, instigando reflexões sobre desigualdades raciais e preconceitos religiosos e étnicos.

Voltando-nos para a publicidade, o artigo "Rememorado a Primeira Guerra Mundial: apropriações da memória coletiva pela publicidade britânica no ano do centenário (1914-2014)", de Gisela Castro e Vera Pasqualin (ESPM-SP) apresenta análise de duas peças publicitárias que provocam tensionamentos sobre memória individual, coletiva, afeto e consumo. Também relacionado às relações entre memória, consumo e publicidade, mas com tema, objeto e questões distintos, o artigo de Victor Gomes (UCB) e Renata Andreoni (PUC-RS) se utiliza da Análise do Discurso para compreender sentidos construídos por uma campanha de uma rede de supermercados, que enfatiza certos ideais de felicidade com base em memórias sociais.

Dando continuidade ao dossiê, os três artigos seguintes lidam com o universo cinematográfico e suas relações com a memória. Em "Usos e instrumentalizações da memória em reaberturas de antigos cinemas: De Roma, um caso belga" Thalita Ferraz (ESPM-RJ) argumenta como a reativação de salas de exibição está relacionada a táticas de gestão cultural e memória das audiências, que deve ser foco de atenção e investigação. Em "Memória e potência no cinema de experiência pessoal" Roberta Veiga (UFMG) discute sobre a escrita fílmica de si e sua potência subjetiva de entrelaçamento entre memória e esquecimento, enquanto Cristiane Gutfreind e Rafael Valles (PUCRS), por sua vez, promovem uma reflexão sobre a obra do realizador espanhol José Luis Guerín, investigando como a questão da memória é construída em seus filmes e como as imagens são centrais para tal.

Finalizando o dossiê Grécia Falcão (UERJ) discute sobre questões de veracidade e memória a partir de exposições fotográficas de artistas 
contemporâneos, buscando "romper com a representação histórica que aprisiona os sentidos dos arquivos".

Na seção de temas livres o artigo de João Carrascoza (ESPM-RJ) discute sobre as reconfigurações pelas quais passa o trabalho publicitário no cenário contemporâneo, permeado por tecnologias digitais, enquanto Renata Tomaz (UFRJ), por fim, apresenta levantamento da literatura sobre as relações entre mídia e infância, apontando para a importância de se entender a criança não enquanto "produto da cultura", mas como "problema teórico".

Aproveitamos o ensejo para informar ainda que a partir do ano que vem a Contracampo irá funcionar segundo o modelo Ahead of Print, que permite a publicação dos trabalhos tão logo são aprovados, bem como passará a ser bilíngue, visando a rapidez e expansão do alcance do conhecimento co-construído a partir da mediação da revista.

Gostaríamos de desejar um excelente 2017 a todas e todos!

Com os melhores cumprimentos,

Beatriz Polivanov, Thaiane Oliveira e Marco Roxo.

Editores-chefes da Revista Contracampo 


\section{EQUIPE EDITORIAL}

\section{Editores-chefes}

Beatriz Polivanov (UFF)

Thaiane Oliveira (UFF)

Marco Roxo (UFF)

Simone Pereira de Sá (UFF)

Angela Prysthon (UFPE)

\section{Editores-executivos}

André Bonsanto Dias (UFF)

Camilla Quesada Tavares (UFF)

Clara Câmara (UFF)

Melina Meimaridis (UFF)

Priscila Mana Vaz (UFF)

Tatiana Lima (UFF)

\section{Revisão e Tradução / Versão}

Leandro Aguiar (UFF)

Patrícia Matos (UFF)

Schneider Ferreira Reis de Souza (UFF)

Simone Evangelista (UFF)

\section{Projeto gráfico / Diagramação}

Paulo Alan Deslandes Fragoso (UFF)

\section{Equipe de comunicação}

$$
\begin{gathered}
\text { Beatriz Medeiros (UFF) } \\
\text { Diego Amaral (UFF) } \\
\text { Julia Silveira (UFF) } \\
\text { Natalia Dias (UFF) }
\end{gathered}
$$




\section{Dossiê}

Mídia e

Memória

vol. II 


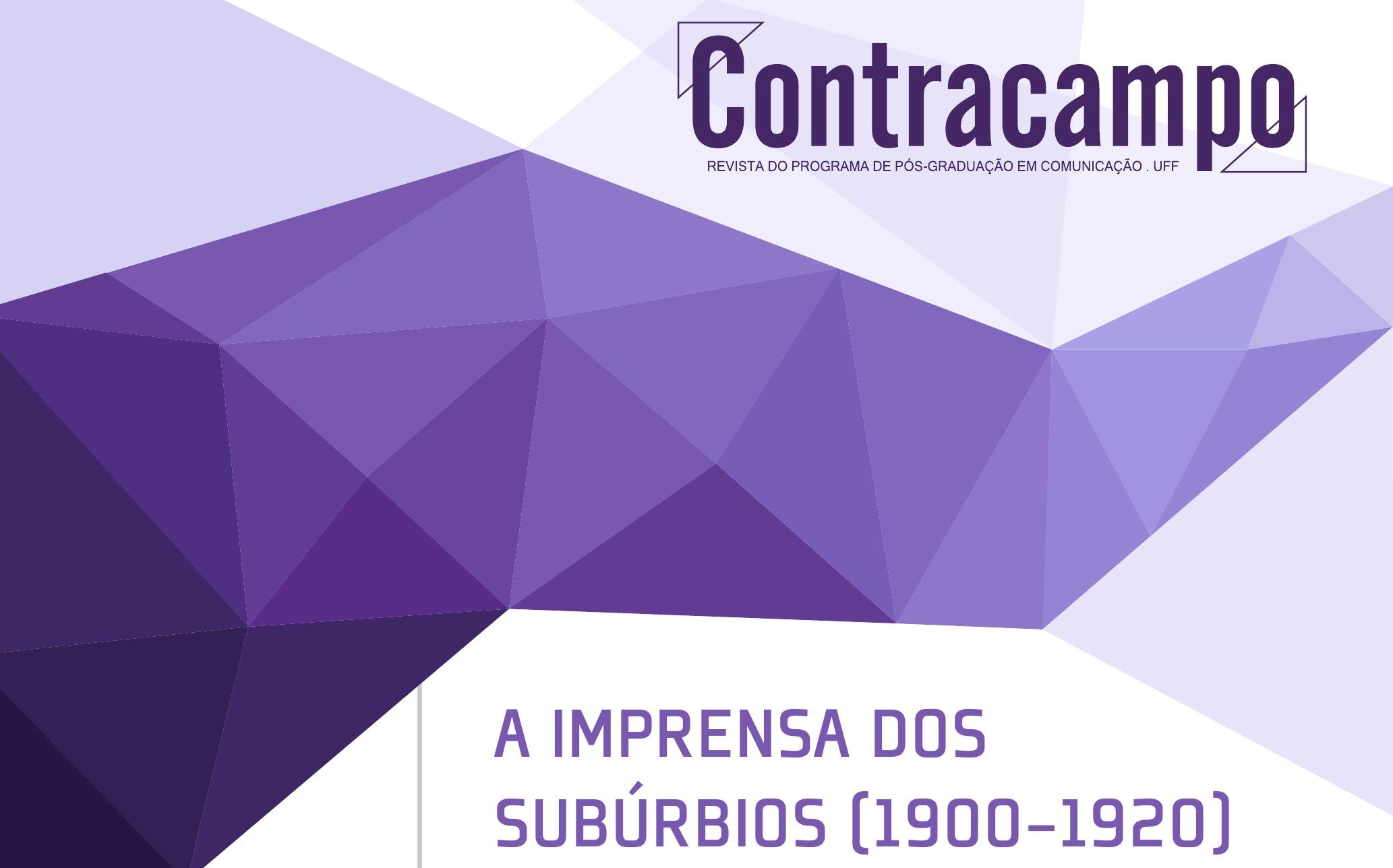

\section{Edição v.35}

número 3 / 2016-17

\section{THE SUBURBAN PRESS [1900-1920]}

Contracampo e-ISSN 2238-2577

Niterói (RJ), v. 35, n. 3

dez/2016-mar/2017

A Revista Contracampo é uma revista eletrônica do Programa de Pós-Graduação em Comunicação da Universidade Federal Fluminense e tem como objetivo contribuir para a reflexão crítica em torno do campo midiático, atuando como espaço de circulação da pesquisa e do pensamento acadêmico.

\section{LETICIA CANTARELA MATHEUS}

Professora de Comunicação Social da UERJ, membro do Programa de PósGraduação em Comunicação na mesma universidade. Doutora em Comunicação pela UFF. Atualmente é coordenadora do GP de História do Jornalismo da Sociedade Brasileira de Estudos Interdisciplinares da Comunicação (Intercom). Brasil.

leticia_matheus@yahoo.com.br.

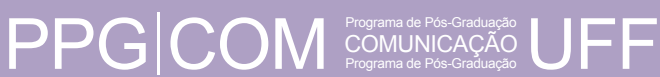

AO CITAR ESTE ARTIGO, UTILIZE A SEGUINTE REFERÊNCIA:

MATHEUS, Leticia Cantarela. A imprensa dos subúrbios (1900-1920). Contracampo, Niterói, v. 35, n. 03 , dez. $2016 /$ mar. 2017.

Enviado em 11 de setembro de 2015 / Aceito em: 29 de março de 2016. 


\section{Resumo}

O artigo apresenta uma pesquisa em andamento sobre como o jornalismo contribuiu para a elaboração de um conceito carioca de subúrbio e como essas regiões foram narradas entre os anos 1900 e 1920 tanto na chamada imprensa suburbana quanto nas colunas dos periódicos de grande circulação que eram dedicadas a notícias sobre aquele espaço social específico. Uma hipótese é que houve disputas em torno das idealizações sobre esses bairros e que algumas delas acabaram por legitimar um processo de permanente produção da diferença, não apenas simbólica, mas efetivamente de investimentos públicos. A pesquisa pretende compreender como os jornais servem como ferramenta para elaboração de uma imaginação histórica sobre a cidade, reforçando ou contestando mecanismos de diferenciação e hierarquização dos espaços.

\section{Palavras-chave}

História do jornalismo; Narrativa; Cidade

\section{Abstract}

This paper presents a research on how journalism has contributed to the development of a concept of suburb in Rio and how these regions were reported between 1900 and 1920 by both so-called suburban press and the columns of leading newspapers that were devoted to news on that particular social space. One hypothesis is that there were disputes over idealizations about these neighborhoods and some of them eventually legitimize a process of continuous production of difference, not only symbolic, but effectively on public investments. The research aims to understand how the newspapers serve as a tool for developing a historical imagination of the city, reinforcing or challenging mechanisms of differentiation and hierarchy of spaces.

\section{Keywords}

History of journalism; Narrative; City 
O significado e a ocupação dos espaços encontram experiências singulares no passado que ajudam a compreender o momento presente não somente por suas diferenças, mas também pelos sentidos que permanecem. Num momento em que a capital do estado do Rio de Janeiro experimenta grandes reformulações, com desapropriações de casas populares, impactantes reformas viárias, como a demolição do Viaduto Perimetral, ou o projeto de revitalização da zona portuária chamado "Porto Maravilha", entre outras, todas a pretexto dos megaeventos esportivos, é inevitável a comparação com a gestão do prefeito Pereira Passos (1902-1906), que promoveu grandes reformas urbanas na área central da cidade. Mas, enquanto esse processo se dava, a urbanização de outro espaço não costuma ser lembrada com a mesma frequência, inclusive em estudos históricos de natureza comunicacional: os subúrbios cariocas, nome que se dá a uma parcela das zonas Norte e Oeste da cidade, caracterizada sobretudo por sua relação com a linha do trem.

A chamada "Zona Sul", como sinônimo de área rica, ainda se encontrava em fase inicial de desenvolvimento, e a expansão habitacional se dava principalmente para outro lado: ela acompanhava as linhas do trem pelo ramal da Leopoldina (costeira) e pelo ramal da Central do Brasil (continental). Cada qual com suas particularidades, essas regiões abandonavam gradativamente sua configuração rural para assumirem, não sem dificuldades e contradições, uma feição urbanizada, ainda que os recursos infraestruturais fossem distribuídos pela cidade de modo desigual. Aos subúrbios restavam poucos investimentos, apesar da sua disparada demográfica. Para se ter uma ideia, os bairros vinculados à Leopoldina cresceram populacionalmente $293 \%$ somente entre 1890 e 1906. (SILVEIRA, s/d, p. 6). Se, inicialmente, ainda no século XIX, os assentamentos nessas freguesias traduziam a lógica da prevalência de moradores com determinadas profissões, com vilas operárias, aos poucos essa população foi se tornando mais heterogênea. Naquele momento, na virada do século, acontece um boom de "jornais de bairro", uma profusão de semanários e de revistas literárias destinadas 
aos ilustrados moradores dos subúrbios.

Este artigo discute, portanto, essa imprensa que estamos chamando de suburbana, dentro de um contexto de expansão da palavra impressa e de alargamento da experiência jornalística no cenário do Rio de Janeiro (Barbosa, 2007 e Mendonça, 2014, p. 41), bem como de integração e de reordenamento da cidade sob parâmetros considerados modernos. Aquele modelo de modernidade encontrava nas reformas das áreas centrais sua referência - segundo o que ficou traçado a posteriori -, mas, nos estudos sobre o período, costuma-se deixar invisíveis processos paralelos de modernização, tais como no subúrbio carioca. O objetivo é, portanto, acrescentar à imaginação histórica a perspectiva dos suburbanos sobre o processo de modernização do Rio de Janeiro, e estudar de que modo eles operaram no espaço público por ações de comunicação, tendo aqui, como objeto privilegiado, esses jornais "de bairro". Como os moradores enxergavam seu lugar de trabalho e de moradia? Como tentavam interferir nos processos de significação daquele ambiente, em diálogo com autoridades e com moradores de outras regiões, através da publicação de seus próprios periódicos? Faziam eles um jornalismo singular?

\section{Demarcação territorial}

Não temos interesse na dimensão profissional do jornalismo mas no seu caráter cultural, como experiência narrativa, dentro de um sistema de comunicação. Essa tem sido a identidade de nosso trabalho desde 2004. É evidente que ele contribui para a compreensão do jornalismo, mas suas práticas são tratadas aqui como parte de processos de comunicação que as atravessam e que são atravessadas por elas. Entendida como mediadora da experiência urbana, graças à sua condição narrativa, essa imprensa suburbana também assume o caráter de vestígio do passado, como um conector possível com os homens e mulheres daquele tempo.

Entendemos que a definição do que fosse o subúrbio carioca não 
se deu exclusivamente pela mediação desses jornais, cuja influência provavelmente foi muito restrita. Eles apontam muito mais para um desejo de comunicação e para a formação de uma imaginação histórica sobre o subúrbio. Para os cariocas, "subúrbio" possuiu um significado muito particular que se confunde tecnicamente com aquilo que se entende em outras capitais brasileiras por periferia. ${ }^{1}$ Tratase de um conceito híbrido que incorpora certa ideia de exclusão, porém não necessariamente por uma questão de classe, associada, paradoxalmente, a um ethos aristocrático. Enquanto "subúrbio" carrega normalmente uma noção de espaço privilegiado, de distinção social pelo seu afastamento dos problemas do centro, como por exemplo, nas áreas ricas com casas de luxo nos Estados Unidos, no Rio, essa distância da área central conota sentido inverso, uma espécie de pertencimento descentralizado à cidade, o que não significa que os agentes dessa imprensa que estudamos possam ser caracterizados como socialmente excluídos ou vulneráveis.

Oriundos das classes médias, muitos desses agentes impressores eram imigrantes portugueses e de outras nacionalidades, habituados à cultura letrada impressa. Alguns deles já trabalhavam na grande imprensa carioca. Além de conteúdo político, era comum que os periódicos por eles publicados trouxessem denúncias e exigência por "melhoramentos" por parte da Prefeitura e da Intendência Municipal. Naquele momento, havia a nítida percepção da desigualdade dos investimentos públicos na cidade. (cf. Moreira, 2013)

Segundo Mendonça (2014), ao tomarem a iniciativa de publicar um jornal, moradores mais abastados dos subúrbios visavam se notabilizar como representantes dessas regiões, com o intuito de melhorar a infraestrutura local, mas também para tentar se integrar, ainda que marginalmente, à vida pública da capital. Outra hipótese é que a proliferação desses jornais também possa ter sido uma tentativa 
de autonomia dos "suburbanos" tanto em relação às representações hegemônicas dos grandes jornais quanto à tendência à relativa invisibilidade daqueles territórios para a administração pública, já que, como dissemos, alguns deles já trabalhavam na grande imprensa local, sendo responsáveis pelas colunas dedicadas às causas dos subúrbios.

Mas, apesar de terem se caracterizado por experiências muito pontuais, é preciso admitir que 1) o sistema midiático da época era mais restrito e não temos condições, pelo menos por enquanto, de imaginar o impacto social desse conjunto de jornais tomando como parâmetro a complexidade do mundo contemporâneo; 2) esses jornais podem sim trazer implicações teóricas para entender a relação entre mídia e cidade.

A definição em torno dos subúrbios cariocas é marcada pela presença da Estrada de Ferro Central do Brasil (antiga Dom Pedro II), inaugurada em 1858, mas esse território cultural varia historicamente e não coincide geograficamente de modo exato com os bairros e os municípios que margeiam os ramais da linha férrea. Sequer os bairros possuíram o mesmo desenho sempre, sendo permanentemente territórios negociados. Em um brilhante estudo sobre a imprensa do interior paulista, Losnak (2011) descreve a contribuição do jornalismo na definição de região, no Oeste paulista, durante a primeira metade do século XX. A Estrada de Ferro Noroeste do Brasil ligava São Paulo ao Mato Grosso do Sul e, no trecho paulista, passava por pelo menos 11 municípios, chegando até a fronteira com a Bolívia e com ramal também para o Paraguai. O trem funcionava como a principal mídia, mas carregava dentro dele outra mídia, num sentido tão concreto que se torna impossível ignorar o princípio mcluhaniano de uma mídia dentro de outra mídia, "gritando" neste caso em sentido literal. O Diário do Noroeste não apenas era distribuído pelos 11 municípios pelo trem como circulava dentro dele. Com sede em Bauru, o periódico cobria toda a região, e ainda tornava a própria ferrovia personagem, com reportagens sobre assaltos nas linhas, e sobre o cotidiano nas estações e nas viagens. Ao potencializar a interação entre essas diferentes 
cidades, numa extensão de 1.250 quilômetros, o Diário do Noroeste ajudava a desenhar uma territorialidade cultural do Oeste paulista. No caso do Rio de Janeiro, não temos evidência de que esses jornais suburbanos circulassem pelo trem. Observando, como propõe Losnak, os títulos dos periódicos, percebe-se que a designação espacial que eles propunham se sobrepõe apenas parcialmente ao recorte ferroviário. O mesmo se pode afirmar ao observarmos seus cabeçalhos, com a indicação da área de circulação, alguns por mais de um bairro, mas não absolutamente coincidentes com os ramais do trem. Por exemplo, havia o jornal O Suburbano, da Ilha do Governador, que não possui linha férrea nem é considerada um bairro do subúrbio.

Essa espécie de designação autorizada sobre o espaço estava em disputa não apenas entre esses semanários dos bairros. Diários de grande circulação mantinham colunas com cobertura exclusiva chamadas, por exemplo, "Subúrbios" (Jornal do Brasil), "Pelos Subúrbios" (Correio da Manhã), que mais tarde se tornou "Correio Suburbano" e depois "Subúrbios e Arrabaldes" (Barbosa, 2007, p. 42). Havia ainda a coluna "Queixas do Povo", que também costumava trazer denúncias sobre os problemas enfrentados pelos moradores dos subúrbios. Esses dois importantes títulos não eram exceção: toda a grande imprensa ${ }^{2}$ da época dedicava espaço àquela nova região que ampliava as fronteiras urbanas da cidade do Rio de Janeiro.

Os primeiros assentamentos naquela região obedeciam a uma forma linear, ao acompanharem as linhas do bonde, primeiro, e depois do trem. Os subúrbios teriam experimentado uma espécie singular de modernidade, diferente daquela propalada pelos grandes jornais acerca da região central reformada, experimentando uma Bélle Èpoque a seu modo. Exatamente as linhas de trem aparecem em profusão como protagonistas nas fotografias realizadas por Augusto

2 O termo "grande imprensa" pode parecer anacrônico, mas estamos assumindo que, de fato, esses jornais representavam, junto com outros, a grande imprensa da época, adotando a conceituação de Barbosa (2007), uma vez que, como descreve a autora, os principais jornais da época, no Rio de Janeiro, já possuíam configuração empresarial e que a soma total das tiragens diárias, bem como o número de títulos disponíveis, permite afirmar que se tratavam de grande imprensa. Deixaremos a análise dessa parte do nosso corpus empírico para outra oportunidade. 
Malta, fotógrafo oficial da Prefeitura na virada do século. Responsável pela produção oficial de imagens do período, especialmente das intervenções da administração pública, Malta se dedicava a registrar as reformas no Centro e na crescente Zona Sul. Quando documentava os chamados "melhoramentos" pelos quais passam os subúrbios, quase invariavelmente aparecia a linha férrea. ${ }^{3}$

O que impressiona de antemão é a quantidade de títulos na época reivindicando essa categorização "suburbana" no título. Mas havia também outros que ostentavam orgulhosamente o nome de cada bairro, além dos casos em que não se pode inferir seu local de publicação e de circulação. Para essa pesquisa em andamento, fazem parte do corpus empírico nove periódicos que circularam entre 1900 e 1920: Tribuna Suburbana e Jornal Suburbano (Madureira), Echo Suburbano (Engenho de Dentro), O Suburbano (Ilha do Governador, Méier, Madureira, Inhaúma), Progresso Suburbano (Piedade) e Revista Suburbana (Méier). Essa imprensa suburbana precisava lidar não apenas com as representações hegemônicas acerca dos subúrbios cariocas, mas também enfrentar o problema de reformular a memória de um passado rural das freguesias.

Figura 1:

3 O acervo está disponível no Portal Augusto Malta (http://portalaugustomalta.rio.rj.gov.br/), ligado ao Arquivo Geral da Cidade do Rio de Janeiro (www.rio.rj.gov.br/arquivo/acervos.html). 


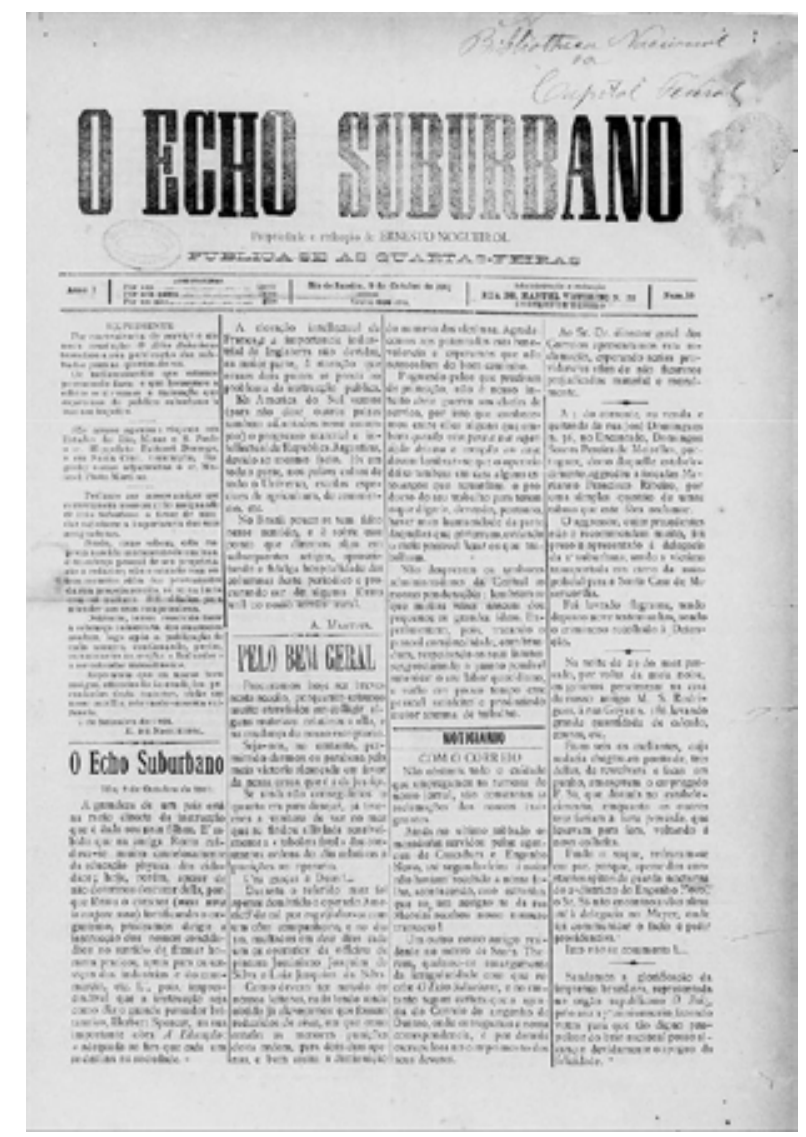

O semanário O Echo Suburbano, de Engenho de Dentro, primeira página de 09/10/1901

Fonte: Hemeroteca Digital da Biblioteca Nacional

\section{Imaginação histórica}

Em outra oportunidade (MATHEUS, 2011), tratamos da contribuição da experiência jornalística, especialmente na sua dimensão noticiosa, para a difusão e sedimentação de uma ideia de história predominantemente linear, factual, direcionada, baseada na lógica do progresso tecnológico. Não estamos negando essa tese, mas, agora, em vez de falar em uma "história midiática", um tipo de percepção histórica construído especialmente pelo jornalismo, adotamos o conceito "imaginação histórica". A inspiração nasce do termo correlato "imaginação sociológica", de Mills (1982 apud Barbosa e Ribeiro, 2011, p. 12), pensado como podendo ser substituído por "imaginação histórica", isto é, como dada possibilidade imaginativa sobre ser no tempo e no espaço. A adoção do substantivo "imaginação", em vez de simplesmente falar em história, serve para tentar reduzir eventuais 
constrangimentos ao a associarmos a uma dimensão não científica, que incorpora tanto o senso comum quanto a ficção. A imaginação histórica seria, portanto,

uma percepção que consiga dar conta do complexo jogo que se processa entre os homens e a sociedade, a biografia e a história, o eu e o mundo; uma sensibilidade capaz de relacionar as micro e macroestruturas, de compreender os cenários mais amplos em termos de seus significados para a vida íntima das pessoas. (BARBOSA e RIBEIRO, 2011, p. 18)

O termo "imaginação histórica" aparece em White (2008) e pretendemos seguir sua linha de raciocínio ao aceitar que a consciência histórica é produzida pelos indivíduos também a partir de uma experiência estética. Enquanto White se preocupa fundamentalmente com a forma narrativa de apresentação do texto historiográfico e com certas formatações idológicas que decorrem desses modos de apreensão da realidade (os tropos da linguagem) - ironia, metáfora, comédia, sátira, tragédia, romance e metonímia -, levamos em conta a contribuição da presença do jornalismo no cotidiano do público, como experiência narrativa e, portanto, como forma de estabelecer certa relação com sua própria história. Assim, do ponto de vista de sua contribuição epistemológica, a pesquisa integra a perspectiva de uma poética do jornalismo como modo de contribuição para uma imaginação histórica, assumindo um lugar de interface entre Comunicação e História.

O compromisso com a verdade une os ofícios dos dois profissionais - o historiador e o jornalista -, ainda que ambos se dediquem majoritariamente ${ }^{4}$ a temporalidades diferentes - presente e passado - e que façam uso de técnicas de trabalho próprias. Por outro lado, a experiência do tempo segundo a qual prevalece excessivamente o presente, o "presentismo" de Hartog (2014), parece tributária em grande parte da imersão do sujeito contemporâneo na lógica noticiosa e de consumo acelerado de narrativas midiáticas. Digamos que 
vivemos historicamente imersos em certas condições comunicacionais, regidas por certas temporalidades, as quais Hartog (2013) chamava de regimes de historicidade. Essas condições comunicacionais incluem não somente os recursos sociopolíticos, culturais e materiais de enunciação, mas também o poder de fazer circular e amplificar os enunciados, bem como as habilidades cognitivas dos sujeitos envolvidos nesses circuitos. Esse processo irá resultar, em última instância, na produção de sentido sobre a própria realidade. Os meios de comunicação são ferramentas que integram esse processo, de maneiras mais ou menos institucionalizadas, e não se pode ignorar que os homens produzem história no mundo contemporâneo por meio de ações altamente mediadas tecnologicamente, culturalmente e economicamente, isto é, por isso que estamos genericamente chamando de mídia. Mas a história, embora se faça apenas no presente, não é feita apenas de presente. Paradoxalmente, ela depende de atos de comunicação com os mortos. Já os comunicólogos não podem fugir do presente, sob pena de perder o próprio posto de trabalho na disputada fábrica do pensamento social. E nenhum agente de comunicação social depende tão integralmente de seu vínculo com o presente imediato do que o profissional de jornalismo.

Servo da atualidade, o jornalista, entretanto, ajuda na elaboração de uma imaginação histórica que permite ao público compreender seu passado e seu presente e também a projetar futuros. Nesse sentido, o jornalista se aproxima do ofício do historiador, sobretudo do historiador de outras épocas, cuja função social já foi muito diferente daquela do cientista moderno. Existem muitas diferenças - e semelhanças entre os dois trabalhos, mas já houve um tempo em que o historiador servia à sociedade como uma espécie de repórter do tempo presente. Essa concepção não foi totalmente apartada do trabalho do historiador, como um analista da realidade, embora ele tenha passado por alguns momentos de abandono dessa função, como quando se agarrou a uma perspectiva positivista, viciado na narração dos fatos. Mas, certamente, o desempenho dessa função passa hoje pela mídia, como apontou Nora 
(1976), tendo o jornalismo um estatuto comunicacional singular nessa tarefa.

A pesquisa adota duas teorias narrativas para tentar compreender o papel do jornalismo na construção de uma imaginação histórica. A primeira, advinda de Ricoeur (1994), serve mais a uma base metodológica, mas existe um fundamento que a antecede que se encontra na teoria da narração de Walter Benjamin (1994). A partir desse autor, pode-se partir em direção ao entendimento da experiência histórica como experiência narrativa, o que aparece de forma exaustiva em Ricoeur. Neste último, a história surge como historicidade (tempo) e representação do tempo (narrativa). Além disso, devido à sua proximidade com a perspectiva hermenêutica, que governa o ofício do historiador, e que marca a epistemologia das ciências sociais como um todo (ALBERTI, 1996), entende-se aqui que os sentidos, esse fruto do trabalho comunicativo, devem ser buscados nos processos sociais nos quais diferentes atores se integram, seja de modo ativo seja sofrendo as ações comunicativas do outro. Essa perspectiva entra em acordo com a compreensão do passado como uma variação imaginativa do presente, uma vez que é impossível acessar um tempo que não mais existe.

Além disso, acreditamos, como Benjamin (1994), que o conhecimento, qualquer conhecimento, seja sobre o passado ou sobre o presente, só pode ser dialético. Isso significa que ele não se esgota numa suposta totalidade, seja sobre o presente ou sobre o passado, mas deve ser uma experiência de se encontrar, de se reconhecer no passado e ao mesmo tempo de distanciar dele. Portanto, devemos tentar realizar uma experiência de conhecimento sobre a construção da imaginação histórica sobre os subúrbios do Rio de Janeiro num tempo histórico diferente. Porém, as marcas da imaginação histórica estão impregnadas no próprio território caracterizado como subúrbio, nas páginas impressas dos jornais da época e em novos circuitos de comunicação que redimensionam os antigos circuitos.

O conceito de experiência em Benjamin está relacionado, e até se 
confunde, ao de história. Para ele, uma história não alienada é aquela que pode ser contada por quem a experimentou, por quem possui de fato conhecimento sobre ela. Assim, pode-se perguntar se existiria alguma contradição entre como os subúrbios apareciam no Jornal do Brasil e no Correio da Manhã, e nos semanários que circulavam nos suburbanos. Para Benjamin, fazer história e contar história são ações simultâneas e, eu acrescentaria, dar sentido à história e ao próprio processo de contar. Por essa razão, ao pensar a introdução dos meios de comunicação de massa, Benjamin enxergava uma ruptura entre o fazer e o contar a história, este último trabalho transferido então para mídia. Assim, segundo seu entendimento, a história contada pela mídia seria uma história alienada do fazer histórico e da própria comunidade, que justamente por isso teria seus laços comunitários enfraquecidos. Por isso, seu paradigma narrativo é a oralidade.

Seu princípio apocalíptico estava baseado na preocupação com a alienação do homem em função de seu isolamento comunicacional. Como a narrativa não era mais construída em conjunto, a partir de uma experiência comunitária comum, então o indivíduo seria obrigado a confiar na mídia. Como se fosse o fim da história, pela impossibilidade de se construir junto a narrativa. Daí o temor pela desorientação do indivíduo no mundo moderno do capitalismo industrial. A lição moral, o conselho, era, para ele, uma espécie de coautoria na vida. Estariam o morador e os comerciantes dos subúrbios melhor capacitados para narrar sua própria história em lugar da grande imprensa? Seria a representação (ou a narrativa) de uma questão de lugar? Sabemos que a imprensa suburbana não era homogênea (MENDONÇA, 2014) e que alguns desses periódicos não traduzem o que imaginávamos inicialmente: uma imprensa engajada na melhoria da qualidade de vida daqueles lugares. Muitos não tinham esse compromisso editorial, preferindo exibir a ilustração do homem suburbano e afirmar sua integração à modernidade do resto da cidade. Por outro lado, também encontramos uma pluralidade de subúrbios possíveis nas colunas do Jornal do Brasil e do Correio da Manhã. 
Segundo Gagnebin, no prefácio de Benjamin no Brasil, Heródoto fala de uma polarização entre dois modos de contar a história. Como Heródoto coletou narrativas dispersas, sem a preocupação em fechar um sentido, como Tucídides faria, teria servido de modelo para Benjamin pensar algo parecido ao que Eco definiria como obra aberta, especialmente pelo fato de o encadeamento narrativo em direção a um sentido fim se dar pela continuidade do relato, por uma "dinâmica ilimitada de memória" (GAGNEBIN in BENJAMIN, 1994, p. 13), mas também pela operação de interpretação. Sob essa perspectiva, Heródoto deveria ser considerado muito mais um cronista do que historiador no sentido do senso comum. Desse modo, ele se assemelharia ao jornalista: um contador do cotidiano.

Ainda segundo Gagnebin, a preocupação de Benjamin era que, quando a experiência coletiva se perdia, isto é, quando a comunicação passava a ser altamente mediada, outras narratividades tomavam forma e ganhavam a cena, entre elas, por exemplo, o romance e o jornalismo. "Os dois têm em comum a necessidade de encontrar uma explicação para o acontecimento, real ou ficcional" (id. ibid., p. 14).

Dentro desse quadro, é possível pensar que tipo de sentido de subúrbio está sendo recuperado e o quanto essas histórias são reelaborações idealizadas. A principal hipótese é que se, muitas vezes, hoje, o subúrbio é contado nos jornais como o lugar da falta, como lugar marginal (às margens das ferrovias), essa representação vem de uma longa construção de desigualdade desde a grande imprensa do início do século XX. Por outro lado, adotamos a hipótese antitética de que encontraremos uma diversidade de modos de representação desses subúrbios na imprensa suburbana.

A construção da metodologia da pesquisa deriva da teoria narrativa de Paul Ricoeur (1994). O primeiro passo é produzir uma análise de conteúdo dos jornais estudados. No caso da imprensa suburbana, como as coleções são pequenas, será possível ler e estudar todos os exemplares que circularam no intervalo entre 1900 e 1920. Sabemos que havia muitas outras publicações pelos subúrbios desde pelo menos 
1880 (MENDONÇA, 2014), mas optamos por enfocar as primeiras duas décadas do século XX pelo fato de o período coincidir com as reformas de Pereira Passos da área central da cidade, circunstância que servirá de baliza e fonte de problematização.

Essas coleções se encontram na Fundação Biblioteca Nacional, parte no Setor de Obras Raras e outra parte digitalizada e disponível na Hemeroteca Digital Brasileira. Algumas não são extensas, uma vez que esses semanários e revistas literárias circularam durante poucos anos, obedecendo talvez ao propósito comum na cultura jornalística ainda remanescente na época de usar a imprensa para fins políticos que, uma vez obtidos, tornavam a atividade impressora obsoleta (BARBOSA, 2007). Também é possível que esses impressores não conseguissem manter financeiramente sua empreitada, já que, de modo geral, contavam apenas com anunciantes de pequeno porte, comerciantes locais. De qualquer modo, eles servem como vestígio (BARBOSA, 2013) de um processo comunicacional no passado. O mesmo será feito por amostragem com as colunas "Subúrbios" e "Queixas do Povo" do Jornal do Brasil e "Pelos Subúrbios" do Correio da Manhã.

O segundo passo é aplicar esse conteúdo selecionado a um quadro metodológico composto a partir de Aristóteles para pensar: quais as principais unidades de ação dessas histórias, quais suas peripécias (acontecimentos que alteram o sentido narrativo), quais os principais personagens que agem e que sofrem as ações, quais as estruturas temporais utilizadas (linear, circular, fragmentada etc.), como o subúrbio é caracterizado e por quem.

Com esse material bruto em mãos, partiremos então para a primeira confrontação, ainda em termos textuais: a comparação entre as linhas gerais dessas histórias nos semanários suburbanos e nas colunas do Jornal do Brasil e do Correio da Manhã. Finalmente, partiremos para a confrontação final com a "realidade", obviamente, entendida como um conjunto de interpretações sobre o passado. Essa última etapa reenvia os resultados da análise textual às narrativas vivas, como propõe Ricoeur (1994). Isto é, tentaremos reconectar a 
linguagem ao mundo concreto, às condições históricas de significação daquele espaço social chamado subúrbio. Isso será feito pela comparação com a literatura historiográfica referente ao período, especialmente usando Mendonça (2014) e outros historiadores que se dedicaram ao tema do subúrbio e de historiadores da imprensa, como Barbosa (passim). Assim, será possível compreender os limites históricos da ação comunicativa daqueles homens e também sua inteligência para reinventar simbolicamente seu mundo.

É nessa última fase de análise que de fato entra Ricoeur (1994) com sua teoria narrativa, que funciona como metáfora para o processo comunicacional. A narrativa, para ele, é a colocação das ações humanas na duração e, por isso, pressupõe a comunicação como processo. $\mathrm{Na}$ sua base está a ideia de tripla presença da mimese nas ações humanas: como mundo prefigurado, isto é, como repertório de conhecimento prévio que permite e aciona certos referenciais a partir dos quais se produzirá a narrativa; como configuração no enredo em si; e como ação de interpretação dessas mensagens, isto é, de conexão do texto com o mundo. Portanto, para Ricoeur (ibid.), o problema da referência da linguagem não se encontra exclusivamente no mundo pressuposto a ser representado, mas no mundo projetado pela ação instaurada a partir do texto. Para ele, o sentido da narrativa está na sua frente, no futuro, não no passado. Essa perspectiva entende o fechamento do ciclo de sentido, ou do arco hermenêutico, pela ação do leitor. Desse modo, essa visão ampla sobre a narrativa, não como um gênero literário, mas como uma teoria comunicacional, privilegia a ideia do circuito posto no tempo, isto é, a ideia de processo. Assim, as marcas da comunicação do passado se tornam vestígios de processos de produção de sentido que se deram no passado, irrecuperáveis na sua integralidade obviamente, e sem garantias, pois se trata de um conhecimento essencialmente interpretativo, mas que também projeta conhecimento sobre nossas ações de significar o presente. 


\section{Os jornais suburbanos}

Moradores dos subúrbios participaram a seu modo do boom do periodismo no início do século XX, quando, segundo Damázio (1996), mais de $60 \%$ da população lia jornais no Rio de Janeiro, e a grande imprensa possuía tiragem relativa impressionante se comparada ao contexto atual. Segundo Mendonça (2014), a experiência de publicação dessa imprensa suburbana encontra três linhas explicativas gerais. Um primeiro grupo se caracterizaria pela necessidade de exibir refinamento e de tentar se aproximar, através da prática impressa, de um ideal de Bélle Ėpoque alardeado pela grande imprensa em relação às regiões mais chics da cidade. Os jornais desse segmento não costumavam evidenciar seu endereço de publicação nos títulos. Não havia referência explícita ao pertencer aos subúrbios, como num jogo de representação às avessas, como se dissessem "Eu me autorrepresento reivindicando similaridade ao outro". Por isso, não importava destacar sua área de circulação. Como não reivindicaram uma identidade suburbana, tinham nomes genéricos como Lux ou $O$ Scenário ou $O$ Condor, o que não significa que não destacassem e promovessem os talentos e a inteligência de seus moradores. Eram fundamentalmente impressos literários.

Um segundo grupo de jornais, mais amplamente estudados, refere-se à luta operária, já que os subúrbios cariocas foram importantes pontos de industrialização no estado do Rio, onde ficavam principalmente as fábricas da indústria têxtil. Nesse caso, a preocupação era com os direitos dos trabalhadores e com seu bem-estar, independentemente do local de moradia, mas seus principais militantes eram oriundos dos subúrbios.

Figura 2: 


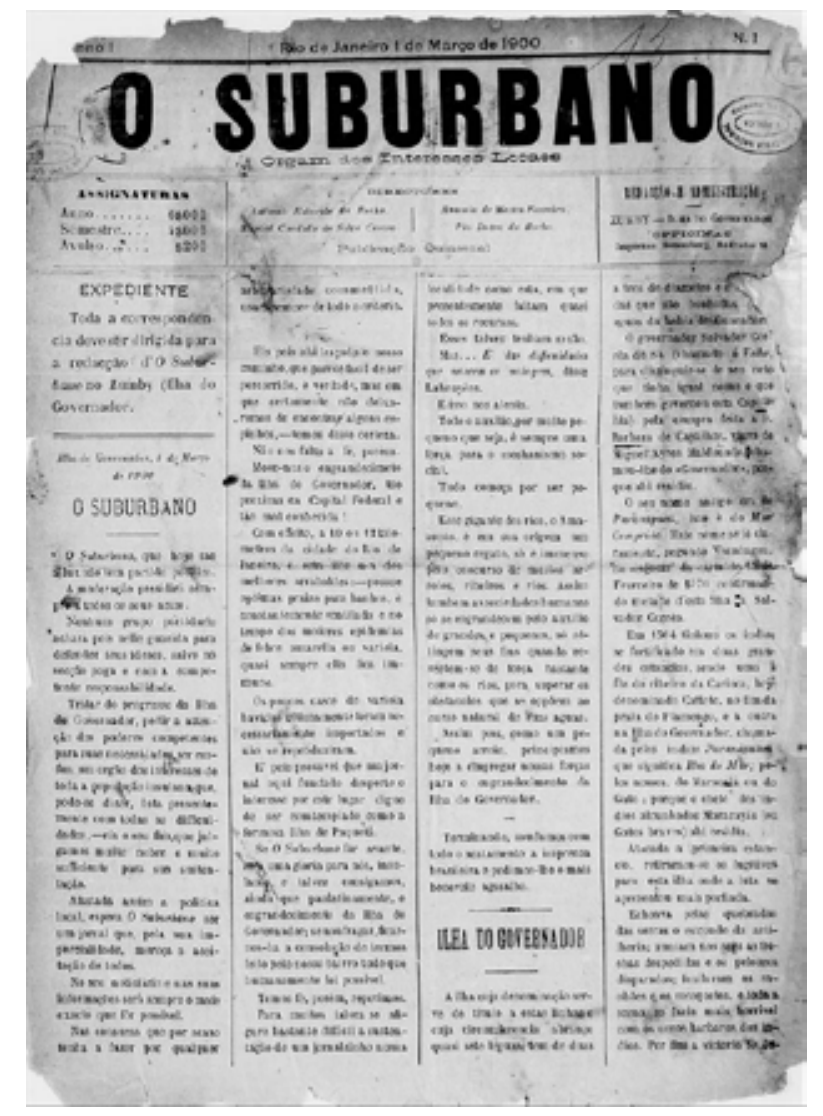

O Suburbano, da Ilha do Governador, primeira página de 1;03;1900

Fonte: Hemeroteca Digital da Biblioteca Nacional

Finalmente, um terceiro conjunto de periódicos, e que constitui o corpus desta pesquisa, tinha como proposta reivindicar melhorias infraestruturais semelhantes às que eram dispensadas à região central. Nesse caso, os jornais acentuavam no título seu pertencimento aos bairros do subúrbio e denunciavam a desigualdade de investimentos entre as diferentes regiões da cidade bem e o que consideravam estado de abandono. Esse grupo defendia o que identificava como interesses locais, demandando um tratamento igualitário em relação ao restante da cidade. Apesar de afirmar estabelecer um diálogo com "todo e qualquer leitor, seja do subúrbio ou não" (MENDONÇA, 2014, p. 51), a produção era resguardada para os moradores dos subúrbios. Entre eles estavam inclusive aqueles que já trabalhavam na grande imprensa, como José Roberto Vieira de Mello, redator do Correio da Noite (proprietário da Gazeta Suburbana e da Revista Suburbana), 
os irmãos Benjamin e Eduardo Magalhães, que assinavam a coluna "Nos Subúrbios" do jornal A Época (proprietários do semanário $O$ Suburbano), Pinto Machado, ligado ao movimento operário, que atuou na seção suburbana do jornal $A$ Tribuna (foi diretor do Echo Suburbano e escrevia para a Revista Suburbana) e Ernesto Nogueirol, que trabalhou no Jornal do Brasil (era colaborador do Echo Suburbano), segundo Mendonça (2014, pp. 56-57). Aparentemente, esses homens entendiam sua inserção na imprensa como uma ação estratégica para a defesa dos seus ideais e tentavam espraiar sua presença o máximo possível, fosse na grande imprensa, fosse nos jornais de bairro, o que às vezes podia causar diferentes conflitos de interesse, conforme vamos investigar. De qualquer modo, fica claro que eles não se contentavam com os grandes jornais e acreditavam na necessidade de abrir outras frentes de diálogo, reproduzindo ou não um modelo jornalístico similar ao da grande imprensa da época.

Para tentar criar e manter vínculo com seu público, eles criaram uma rede de colaboradores, que podiam enviar tanto artigos de fundo quanto "notas informativas, entrevistas e reportagens que valorizassem aspectos cotidianos da cidade" (MENDONÇA, 2014, p. 54). Essa rede de repórteres extrapolava os limites do próprio bairro, privilegiando a circunscrição mais ampla pelos subúrbios. Assim, cobriam desde as ações da Prefeitura naquela região até casamentos, aniversários, formaturas e festas em clubes, dando visibilidade à vida da população local. A colaboração para a sobrevivência dos jornais também se dava pela assinatura e pela aquisição de espaço publicitário pelos comerciantes locais. Do ponto de vista editorial, Mendonça aponta para uma divisão: alguns se assumiam políticos e outros tentavam se mostrar como modernos, vinculados à prática da imparcialidade. Entretanto, não percebemos essas fronteiras tão marcadamente, havendo, de modo geral, forte tom de engajamento político nos periódicos. Apesar de a investigação estar em andamento, também tem se revelada cada vez regular a presença da crítica à grande imprensa.

Em carta aberta ao prefeito, O Suburbano, da Ilha do Governador, 
de 15 de março de 1900, reclamava a construção de mais uma escola pública na Praia das Flecheiras, pois as duas que havia ficavam muito distantes para atender a toda a região - uma na estrada do Galeão, a outra em Itacolomy - e as crianças tinham que caminhar 4 quilômetros até elas. O redator alertava que o Jornal do Brasil já havia feito tal requerimento há pouco mais de uma semana. O jornal também criticava o abandono das igrejas católicas, algumas do século XVIII, destruídas. Desse modo, o jornal estava não apenas fazendo uma reivindicação no presente, mas também projetando uma imaginação sobre o passado da Ilha do Governador. Do mesmo modo, nós, no tempo presente, projetamos o passado, num exercício imaginativo, ao ler esses textos. O Suburbano recebia cartas no Zumby (Praia do Zumbi), onde ficava a redação. Sua oficina gráfica ficava na Rua Andradas, 16.

Echo Suburbano, de Madureira, possuía diagramação mais clean, na década seguinte. O veículo, que tinha tanto a redação quanto a gráfica localizadas na Rua Marechal Rangel, 105, critica, em 13 de agosto de 1911, dois jornalistas de $O$ Paiz e de $A$ Tribuna, que "foram a campo" e relataram em seus artigos de fundo a miséria da cidade. Assinando como "Muzico Allemão", o redator afirma que

si escriptores consagrados, e aos quaes nunca foram
perseguidos pela miséria, se julgam no dever de tractar de
assumpto tão importante às classes proletárias, é justo que
nós, humildes, entidades do povo, nos julguemos no dever
de auxiliar tão benéfica campanha (ECHO SUBURBANO, p. 1 ,
1911 , sic).

Aparentemente vinculado a um sindicato, provavelmente dos gráficos, o Muzico Allemão debocha da hierarquia representacional da grande imprensa. Somente aqueles que vivem na pobreza poderiam falar sobre ela. Na mesma edição, o jornal reclamava da falta de investimento da companhia de luz Light, que expandia sua rede elétrica em outras áreas da cidade mas que esquecida de atender aos subúrbios.

A Tribuna Suburbana, também de Madureira, tinha até uma coluna que recebia telegramas internacionais. O Progresso Suburbano, "órgão noticioso, recreativo e literário", como afirmava o slogan, 
também possuía projeto gráfico arejado, com cabeçalho bem limpo, com o nome do bairro de origem escrito em letras grandes: Piedade. O redator-chefe era Luiz José de Vasconcellos e a redação e a gráfica ficavam na Rua Dona Maria, 15, mas o jornal procurava oferecer notícias relativas a toda a região suburbana, dividindo a área noticiosa por títulos-rótulos: Meier, Madureira, etc. Havia inclusive ilustrações e também notícias internacionais recebidas por telegramas. Na edição de 06 de agosto de 1902, O Progresso Suburbano pedia que a Diretoria Geral dos Correios que conectasse as linhas telefônicas entre os bairros do subúrbio e que a agência dos correios de Piedade pudesse receber malas diretas. Percebe-se, nesses pedidos, uma vontade não apenas de integração local como também com o restante da cidade. O jornal ainda recebia notícias telegráficas de diferentes municípios do estado do Rio. Todos esses periódicos procuravam se manter com assinatura e custavam em torno de 100 reis o exemplar avulso.

Figura 3:

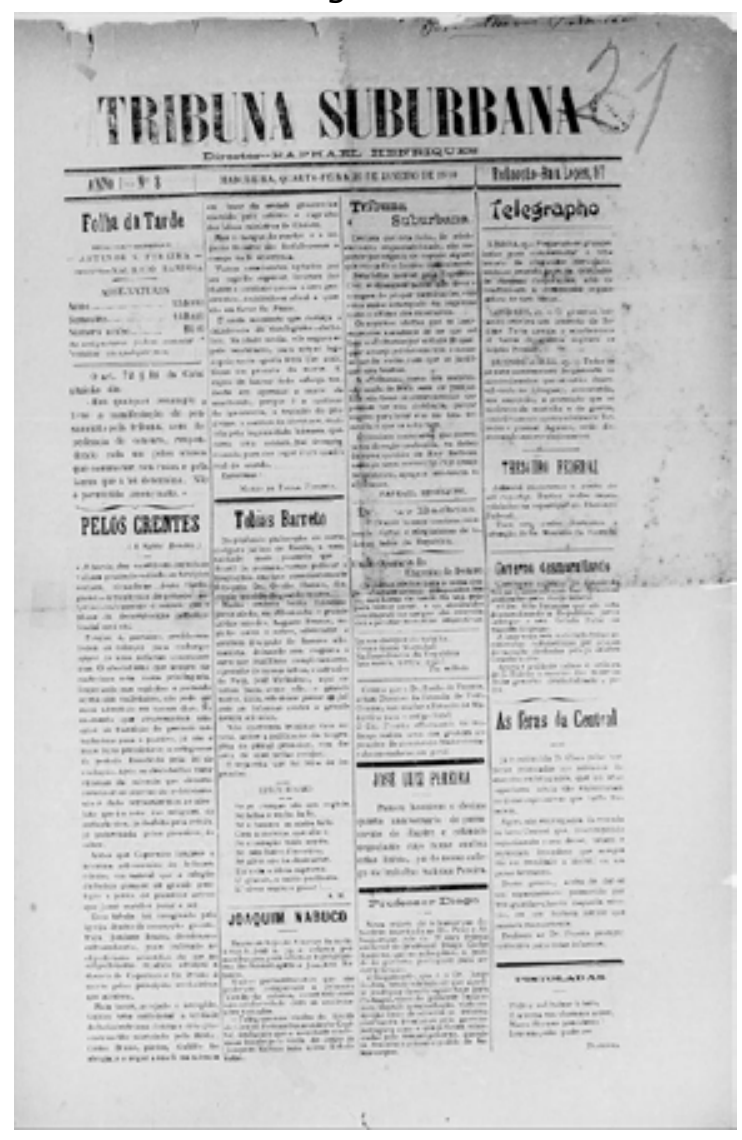


Tribuna Suburbana, de Madureira, exemplar de 26;01;1910

Fonte: Hemeroteca Digital da Biblioteca Nacional

Figura 4:

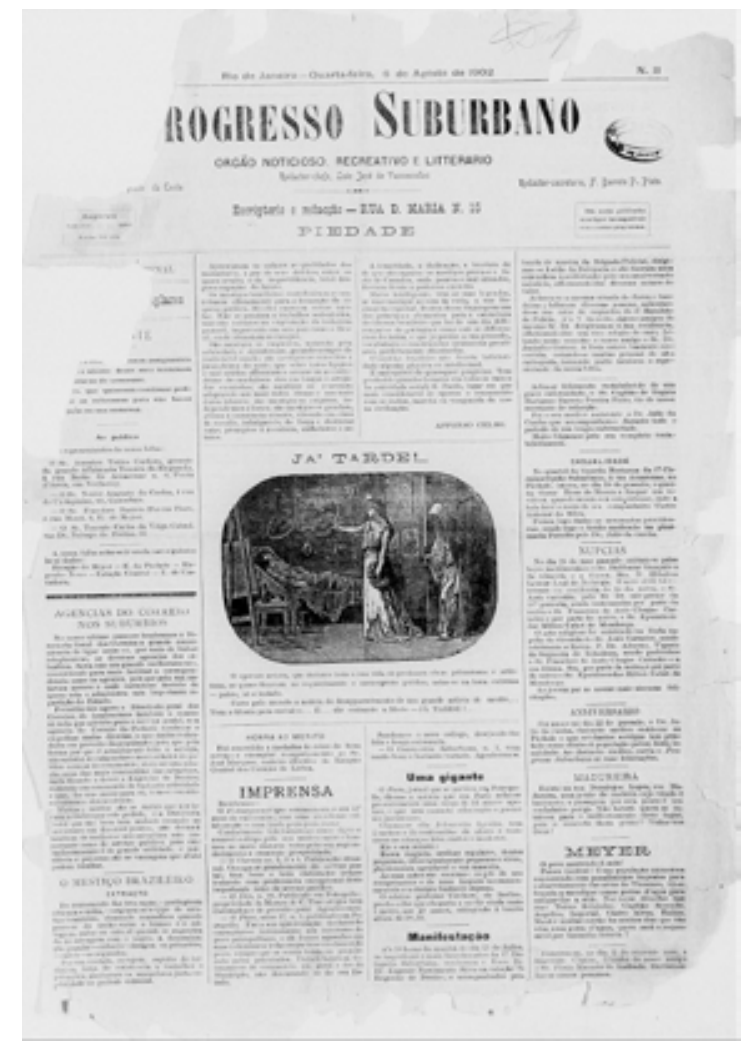

Primeira página de $O$ Progresso Suburbano, da Piedade, de 06;08;1902 Fonte: Hemeroteca Digital da Biblioteca Nacional

\section{Considerações para avançar}

Do ponto de vista da hierarquia dos espaços, esse terceiro grupo de jornais - comprometidos com a promoção dos subúrbios parece mais interessante, pois traz o problema da reivindicação de identidade, da opção estratégica de defesa dos interesses locais por meio da circulação de folhas periódicas, bem como a própria definição em torno do que fossem esses interesses. Esse conjunto de jornais pode ajudar a entender as escolhas estratégicas de comunicação e de ação sobre a própria história por meio de práticas jornalísticas. Num primeiro momento, acreditávamos encontrar nessas iniciativas uma demanda por integrar um processo de modernização em curso na cidade. Assim, a imprensa funcionaria como mais uma ferramenta da modernidade. Mas o contato com as primeiras análises textuais 
mostra que o fenômeno foi mais complexo que isso e talvez a própria ideia de modernidade não fosse um parâmetro consensual sobre viver bem. De qualquer modo, independentemente de esses homens terem ou não obtido sucesso nas suas reivindicações, só o fato de tentarem se colocar como representantes dos subúrbios já significava alguma forma tentar exercer poder sobre aquele território.

\section{Referências}

ALBERTI, Verena. A existência na história: revelações e riscos da hermenêutica. Estudos históricos - Historiografia, Rio de Janeiro, v.9, n. 17, 1996, p.31-57

BARBOSA, Marialva Carlos; RIBEIRO, Ana Paula Goulart. Comunicação e história: um entre-lugar. In: BARBOSA, Marialva; RIBEIRO, Ana Paula Goulart. (Orgs.) Comunicação e história: partilhas teóricas. Florianópolis (SC): Insular, 2011, p. 9-28

BARBOSA, Marialva Carlos. História Cultural da Imprensa. Brasil - 19002000. Rio de Janeiro: Mauad X, 2007.

Vozes, 2013.

História da Comunicação no Brasil. Petrópolis (RJ):

BENJAMIN, Walter. Obras escolhidas. Magia, técnica, arte e política. SP: Editora Brasiliense, vol. I, 1994.

DAMAZIO, Sylvia F. Retrato Social do Rio de Janeiro na virada do século. Rio de Janeiro: EdUerj, 1996.

HARTOG, François. Evidência da História. O que os historiadores veem. Belo Horizonte (MG): Autentica, 2013.

Regimes de Historicidade. Presentismo e experiências do tempo. Belo Horizonte (MG): Autentica, 2014.

LOSNAK, Célio José. Jornais e Ferrovia: uma intervenção social. SP: Anais Confibercom, 2011.

Polifonia Urbana: imagens e representações - Bauru 1950-1980. Bauru; Edusc. 2004.

MATHEUS, Leticia Cantarela. Comunicação, tempo, história: tecendo o cotidiano em fios jornalísticos. Rio de Janeiro: Mauad-X, 2011.

MENDONÇA, Leandro Climaco. Nas margens: experiências de suburbanos com periodismo no Rio de Janeiro 1880-1920. Niterói (RJ): EdUFF, 2014.

MOREIRA, Luciana Verônica Silva. Cidade e subúrbios no Rio de Janeiro do início do século $\mathrm{XX}$ : ordenamento e progresso para o morador suburbano. 
Conhecimento histórico e diálogo social. XXVII Encontro Nacional de História. Anpuh Natal, 2013.

NORA, Pierre. O retorno do fato. In: LE GOFF, Jacques; NORA, Pierre. História: novos problemas. Rio de Janeiro: Francisco Alves, 1976.

RICOEUR, Paul. Tempo e Narrativa. Campinas (SP): Papirus Editora, tomo I., 1994.

SILVEIRA, Marcelo da Rocha. As casas populares e a formação do subúrbio carioca. Mimeo, s/d.

SOTO, William Héctor Gómez. Subúrbio, periferia e vida cotidiana. Estudos Sociedade e Agricultura, vol. 16 no. 1, abri, 2008, p. 109-131

WHITE, Hyden. Meta-história. A imaginação histórica do século XIX. SP: Edusp, 2008. 


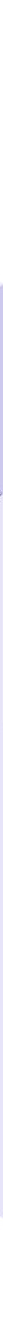




\section{Resumo}

Este artigo aborda projetos memorialísticos desenvolvidos por meios de comunicação. Iniciativas como Memória Globo, Memória O Globo e Acervo Estadão se mostram, simultaneamente, movimentos de valorização da memória e instrumentos de produção de novas versões sobre fatos passados, envolvendo ou não os veículos jornalísticos. Além de funcionarem como resgate e preservação da história dos veículos, reforçando ou estabelecendo uma determinada identidade, são o que Pierre Nora chamou de "lugares de memória" - espaços físicos ou não onde indivíduos e grupos sociais podem ancorar sua memória, face ao fenômeno da aceleração da história que torna o presente cada vez mais volátil. Ao assumirem esta configuração, colocam em questão aspectos constituintes do jornalismo, tais como critérios de atualidade e novidade, além de fomentarem uma rediscussão dos valores de noticiabilidade.

\section{Palavras-chave}

Jornalismo 1; Memória 2; Memória Globo 3; Centros de memória 4; Valor-notícia 5

\section{Abstract}

This article discusses memoirs projects developed by the media. Initiatives such as Memória Globo, Memória O Globo, Acervo Estadão, are shown, simultaneously, as memory enhancement movements and instruments of production of new versions of past events, whether or not involving journalistic vehicles. Besides functioning as rescue and preservation of the history of vehicles, strengthening or establishing a certain identity, they are what Pierre Nora called "places of memory" - physical spaces or not where individuals and social groups can anchor his memory, given the phenomenon of acceleration of history that makes this increasingly volatile. In assuming this setting, they call into question constituent aspects of journalism, such as criteria of relevance and novelty, and foster renewed discussion of one newsworthiness values.

\section{Keywords}

journalism 1., Memory 2; Memória Globo 3; Memory centers 4; Newsworthiness 5 


\section{Introdução}

As comemorações dos 50 anos da Rede Globo, em abril de 2015, indicam uma crescente valorização da memória como uma chave de leitura da contemporaneidade. Entre os produtos desenhados para a celebração de meio século está um especial para o Jornal Nacional, em cinco edições de 20 minutos, produzido a partir de um encontro com 16 jornalistas da emissora mediado pelo editor-chefe do noticioso, William Bonner. Sentados ao redor de uma mesa no formato da logomarca da Tv Globo, os profissionais foram apresentados pela âncora Renata Vasconcellos:

Nesta semana a Globo vai completar 50 anos. E a comemoração aqui no JN vai ser de um jeito inédito. Para relembrar as coberturas jornalísticas mais marcantes deste período, nós vamos provocar a memória dos autores daquelas reportagens. Para representar os milhares de profissionais que construíram o jornalismo da Globo em 5 décadas, nós reunimos 16 repórteres para dividir experiências, lembranças, informações de bastidores. $\mathrm{E}$ a emoção que tudo isso junto pode provocar. (VASCONCELLOS, 2015, 20/4/2015)

Por meio da projeção de reportagens de época, intercaladas pelos relatos dos repórteres que as produziram, lágrimas, brincadeiras, lembrança de apelidos: uma roda de papo de amigos para buscar no baú das recordações os melhores momentos jornalísticos da emissora.

A série especial, que foi ao ar entre os dias 20 e 24 de abril, contou com cinco episódios, sempre ao final do Jornal Nacional. No último dia, uma surpresa: Cid Moreira e Sérgio Chapelin, que durante 18 anos apresentaram o telejornal, voltaram à bancada. A dupla que marcou a história do telejornal entrou no ar para relembrar momentos marcantes de sua trajetória e de outros apresentadores. Cid e Chapelin fizeram a chamada para o último episódio da série e encerraram com o tradicional boa noite. (MEMÓRIA GLOBO, 2015 s/p)

Contar a trajetória do jornalismo da principal emissora de televisão brasileira por meio dos relatos pessoais dos seus profissionais é um recurso que se insere num quadro de valorização da recordação, no que muitos pesquisadores têm considerado uma cultura da memória (HUYSSEN, 2000; 2009; 2014; RIBEIRO e BARBOSA, 2007). Uma das características desta cultura da memória é justamente a expansão 
da categoria do memorável. Alarga-se o espectro do que merece ser recordado. "No mundo atual, marcado pelo terror do esquecimento, a memória emerge quase como um dever ou obsessão" (RIBEIRO, 2014 p. 76). Ao mesmo tempo, se incorporam novos modos de pensar o passado e relatá-lo, assumindo como válido o depoimento, o relato oral, a escrita de si, o relato autobiográfico.

Projetos memorialísticos crescem em diversas dimensões, seja no cenário politico, cultural, social, empresarial. Mais recentemente, identificamos também iniciativas deste tipo no ambiente jornalístico. Os próprios veículos estabelecem projetos de guarda de sua história. Não se está falando aqui de arquivos jornalísticos, a simples manutenção da produção de um órgão da imprensa para consulta por outros profissionais e pesquisadores. São iniciativas de preservação da memória e da história jornalística daquele veículo em específico.

Este artigo apresenta parte dos resultados de pesquisa apoiada pelo Centro de Altos Estudos da ESPM (CAEPM), a qual se debruça sobre projetos memorialísticos desenvolvidos por meios de comunicação, colocados à disposição do público através da internet, e que também produzem conteúdo novo, através da rearticulação de sentidos e da reconstrução do passado.

\section{A linha do tempo}

A questão do tempo é um elemento central no jornalismo, pois condiciona o processo de produção das notícias, marcado pelas horas de fechamento das edições de jornais impressos, sites informativos, telejornais, revistas e programas de rádio. Dentro das linhas mestras sobre as quais o jornalismo foi construído, tudo é momentâneo, tudo é circunstancial. "O jornalista trabalha simultaneamente contra o tempo e a favor do tempo. A velocidade e a rotina são os dois polos quase absurdos em que ele monta seu mecanismo de ação" (DINES, 2009, p. 67).

As notícias, por serem caracterizadas como bens altamente perecíveis, devem ser reportadas o mais rápido possível. "O jornalismo 
é, em certo sentido, uma espécie de 'simulação' da imediaticidade, já que a realidade distante é reconstituída enquanto singularidade" (GENRO FILHO, 2012, p. 135).

O imediatismo, nesse âmbito, é "um conceito temporal que se refere ao estado de tempo que decorre entre o acontecimento e 0 momento em que a notícia é transmitida, dando existência a esse acontecimento" (TRAQUINA, 2005, p. 37).

Otto Groth, um dos primeiros a defender a "necessidade de fundamentar uma ciência autônoma dos jornais" (GROTH, apud MAROCCO e BERGER, 2006), considerava que a atividade jornalística obedece a quatro categorias - periodicidade, universalidade, atualidade e publicidade (no sentido de publicizar). Por atualidade, ele compreendia a característica de o jornal informar sobre o que é atual, presente, momentâneo, novo. Contudo, atual não é o mesmo que novo. Atual significa que algo acontece no tempo presente.

Nesse sentido, o jornalismo fala do agora, do instante, do que está em desenvolvimento neste exato momento, sendo que o tempo dessa fala também está ocorrendo. É uma delimitação quase cirúrgica do real, pretendendo-se extremamente precisa, em busca do aprisionamento do momento em si, da exatidão do acontecimento, quando ele acontece e é imediatamente relatado pelo jornalismo.

Essa dupla contemporaneidade reforça o caráter de atualidade do jornalismo, ao mesmo tempo em que destaca a notícia como o relato verídico (e nunca como uma versão, dentre tantas possíveis, a respeito de um fato). O jornalista é aquele que colhe o fato, registra o acontecimento e o seleciona para se tornar notícia. O que pode nos levar a concluir que os jornais são os diários da humanidade, contendo os registros dos principais acontecimentos de cada dia. (SANTA CRUZ, 2014 p. 34-35)

A associação entre tempo presente e jornalismo está expressa, em diferentes modalidades, pelos próprios profissionais da notícia. Como relata Santa Cruz (2014), Albert Camus, na Segunda Guerra Mundial, cunhou a frase "o jornalista é o historiador do instante". Caco Barcellos, repórter televisivo, se assume como um historiador do tempo presente. Eliane Brum, repórter, se define como historiadora do cotidiano. Estas percepções guardam ligação com a próxima 
concepção de História do Tempo Presente, surgida na França no final da década de 1970 e início da década de 1980, como aponta o historiador Henry Rousso em entrevista à revista Tempo e argumento.

[A história do tempo presente é uma história](...) na qual o historiador investiga um tempo que é o seu próprio tempo com testemunhas vivas e com uma memória que pode ser a sua. A partir de uma compreensão sobre uma época que não é simplesmente a compreensão de um passado distante, mas uma compreensão que vem de uma experiência da qual ele participa como todos os outros indivíduos (AREND, MACEDO, 2009 p. 202)

O jornalista, portanto, produz relatos calcados em sua experiência e enquanto se dá esta experiência. Nesse sentido, se pode considerar que, no jornalismo, a recriação do real é uma forma de ordenar a leitura do mundo, "produzindo conhecimento legitimado acerca dos eventos que marcam e enredam a contemporaneidade" (BERGER, TAVARES, 2014 p.9). Muniz Sodré e Maria Helena Ferrari (1986) ressaltam que o jornalismo se vale de estratégias de presentificação que pretendem dar ao leitor certa reconstituição mental das cenas narradas.

A novidade objetiva do jornalismo teria assim absorvido o lugar reservado anteriormente a outras práticas narrativas, como um valor oposto ao acontecimento antigo. É a visão do jornalismo como organização discursiva do mundo, um sistema de construção de sentidos, como defendido por Muniz Sodré. Ou a ideia da notícia como um produto cultural "cuja magnitude vai além do ato de informar, situando o indivíduo na complexa sociedade contemporânea" (MOTTA, 2002, p.11). As notícias assumem uma forma narrativa, uma narração da história contemporânea.

Por um lado, são informativas (ainda que impregnadas de elementos das ideologias e dos imaginários de quem a produz). Por outro, essas mesmas notícias instigam a imaginação dos leitores-receptores, que trazem para o ato de leitura toda a memória cultural de que são portadores. (...) O consumo de notícias veiculadas através dos jornais ou das emissoras de rádio e de televisão por uma grande parcela da população mundial é hoje um ato ritualístico que se repete diariamente, através do qual os indivíduos retomam regularmente o contato com a realidade caótica. Ler, ver ou ouvir notícias diariamente se incorporou à cotidianidade, se 
agregou ao ciclo cronológico do homem de hoje. (MOTTA, 2002, p.13)

$\mathrm{O}$ ato de consumir notícias de fato se incorporou à rotina diária da contemporaneidade, independentemente dos conteúdos veiculados e consumidos (MOTTA, 2002, p. 14). Ligar a televisão para assistir noticiário e se situar em relação dos acontecimentos do mundo é um hábito rotineiro de milhões de pessoas em todo o mundo, assim como ler jornais impressos, ouvir rádio ou acessar a internet.

O acontecimento é uma singularidade, uma experiência singular na temporalidade. Assim, o poder da narrativa do acontecimento consiste na exposição do fato social - a narrativa jornalística desta maneira "ilumina" o acontecimento, lança luzes sobre ele, o faz, por uma determinada perspectiva, acontecer. A narrativa temporaliza o acontecimento, o que conduz à constatação de que quem dita o ritmo do nosso tempo é o jornalismo. Há uma imensa diferença entre o acontecimento em geral e o acontecimento jornalístico, porque o segundo é narrado, obedece, portanto, as regras da narrativa com a intenção de construir sentidos e situar seus leitores dentro de uma cartografia previamente mapeada. (SANTA CRUZ, 2012 p. 1)

Se as narrativas jornalísticas registram esse acontecimento fugaz, elas também operam no reconhecimento do cotidiano. O cotidiano como tempo possível, como lugar do acontecimento, como referencial da contemporaneidade. Márcia Benetti e Sean Hagen (2008), a partir das concepções de Agnes Heller, Michel de Certeau e Berger e Luckmann sobre a vida cotidiana, ressaltam que o homem permanece na esfera da vida cotidiana.

A vida cotidiana é repleta de significação, pois é onde os atributos humanos se tornam concretos e é onde o homem se relaciona consigo mesmo e com o outro no tempo presente. O tempo vivido é também opressor, carregando as condições históricas que permitem ao homem exercer suas potencialidades de modo pleno ou limitado. É o tempo possível que nos permite aceitar o que nos é ofertado ou criar o inusitado, sempre nos limites socialmente dados como referenciais de contemporaneidade. (BENETTI; HAGEN, 2008 p.5)

Franciscato, em sua obra A fabricação do presente (2005), mostra como o processo de constituição do jornalismo reformulou a experiência do tempo nas sociedades ocidentais, criando as noções 
de atualidade e de presente. Para ele, o jornalismo atua de forma privilegiada como reforço de uma temporalidade social, enquanto produtor de formas específicas de sociabilidade, construindo um tipo específico de vivência social do tempo presente. O tempo presente está, portanto, muito além de uma qualidade particular de um produto, mas se estabelece como um fenômeno social composto por práticas sociais, relações de sentido e atributos inscritos em produtos culturais. Estes elementos, de acordo com Franciscato, é que tornam a vivência do tempo presente uma experiência concreta, compreensível como um objeto social e dotado de um conteúdo com um sentido partilhado.

Alfred Schutz (2003) procurou estabelecer as bases de uma sociologia fenomenológica, a qual influenciou diretamente Berger e Luckmann, os quais, por sua vez, a partir do conceito de construção social da realidade, fornecem a base para as teorias construcionistas do jornalismo. Schutz, como aponta Moretzsohn (2007), assume como fio condutor de sua obra a reflexão sobre a estrutura dotada de sentido do mundo da vida cotidiana. Para ele, é na vida cotidiana que ocorrem as mediações entre os indivíduos, sendo, portanto, essencial para se compreender as estruturas simbólicas constitutivas do social.

O autor ressignifica o "mundo do sentido comum", ou "mundo da vida", que se origina a partir das experiências, pensamentos e ações dos sujeitos. 'É o mundo assumido como pressuposto, de modo que 'aceitamos sem questionar a existência do mundo exterior, o mundo de fatos que nos cerca' (SCHUTZ, 1979, p.58). Nesse mundo, portanto, não temos interesse teórico, mas um interesse eminentemente prático, e por isso o pensamento cotidiano está menos voltado para a antítese verdadeiro-falso do que para a escorregadia transição provável-improvável. (...) Esse processo de naturalização da vida exige a suspensão da dúvida que nos levaria a indagar por que as coisas são como são. $O$ que, por sua vez, implica a hipótese profundamente enraizada no senso comum de que, até segunda ordem, o mundo vai continuar sendo, essencialmente, o mesmo. (MORETZSOHN, 2007 p. 47-48).

Assim, o senso comum se apoia na crença natural em um mundo, na sua realidade, seu aqui e agora, com um passado e um provável futuro que é dado a todos nós de uma maneira muito semelhante. Essa 
percepção constitui o cimento filosófico do mundo do sentido comum. Para Schutz, a realidade iminente se baseia na verdade aparente da atitude natural. Portanto, o senso comum se apoia nessa noção de "atitude natural", entendida como o modo pelo qual o indivíduo percebe o mundo. Para o senso comum, a ocultação da complexidade é uma das características da vida cotidiana.

Se considerarmos que o jornalismo é uma forma de conhecimento vinculada necessariamente à vida cotidiana e associada ao ideal iluminista de esclarecimento, como propõe Moretzsohn (2007 p. 29), teremos que considerar também que as práticas jornalísticas atuam sobre o senso comum, conformando-o e deformando-o.

O jornalismo é, portanto, um domínio discursivo que opera a reconstrução do real. Nesse sentido, os textos jornalísticos não são a própria realidade, mas um modo de reescrevêla baseado em técnicas específicas que prescindem de critérios como atualidade e interesse público. A concepção de jornalismo como forma de conhecimento faz supor que ele tanto transmite, quanto produz e recria os acontecimentos. (CRUZ, 2014 p.4)

A recriação dos acontecimentos implica, portanto, também num trabalho incessante de urdidura ideológica do real, numa constante construção do cotidiano, operando sobre o senso comum, de maneira performativa, disciplinadora e estabelecendo padrões de normalidade.

\footnotetext{
Ao cobrir os acontecimentos da atualidade o jornalismo procede a elaboração de um conhecimento da vida cotidiana reconhecendo o que move a política, a economia, a cultura e, ainda, o que fica na sombra destas grandes temáticas. A mediação da historicidade da vida cotidiana se encontra vinculada ao jornalismo, e é esta condição que alguns cientistas sociais percebem e incorporam em suas tentativas de capturar o tempo presente, incluindo fragmentos jornalísticos para organizar, a partir deles, o argumento que explica que o tempo presente "é assim". (BERGER, TAVARES, 2014 p. 11)
}

Podemos então considerar que os objetivos do jornalismo são informar e oferecer o presente social. A tarefa de decifrar a atualidade e entregar ao leitor o que compreende como contemporâneo é associada aos critérios de relevância do que o jornalista - ou o jornalismo como instituição - percebe como digno de notabilidade.

O jornalismo é um discurso comprometido com o 
contemporâneo - não apenas como lugar do atual, mas também e especialmente como lugar de objetivações sobre o que importa saber agora e como deve agir o sujeito que está de acordo com seu tempo. (BENETTI; HAGEN, 2008, p.1)

Os efeitos sociais da produção rotineira de notícias podem ser analisados pela perspectiva do poder que a mídia tem de determinar quais assuntos a sociedade, num determinando momento, deve entender como importantes. Conhecida como agenda setting, essa teoria considera que existe uma forte correlação entre a ênfase que a mídia coloca em certos assuntos, seja pelo destaque na apresentação do assunto ou pelo volume de cobertura, e a importância atribuída pela população a essas questões. (MCCOMBS \& SHAW, 1972).

\begin{abstract}
em consequência da ação dos jornais, da televisão e dos outros meios de informação, o público sabe ou ignora, presta atenção ou descura, realça ou negligencia elementos específicos dos cenários públicos. As pessoas têm tendência para incluir ou excluir dos seus próprios conhecimentos aquilo que os meios de comunicação de massa incluem ou excluem do seu próprio conteúdo. Além disso, o público tende a atribuir àquilo que esse conteúdo inclui uma importância que reflete de perto a ênfase atribuída pelos mass media aos acontecimentos, aos problemas, às pessoas. (SHAW, 1979)
\end{abstract}

A teoria do agendamento nos diz que as notícias pautam nosso dia a dia, nossas conversas, e isso acontece com o poder da mídia de selecionar o mais importante, dentre um repertório de fatos, e nos fazer enxergar essa relevância, aderindo a ela. Essa adesão implica um impulso à ação, mesmo que a ação seja somente considerar um acontecimento como um assunto relevante. A mídia não apenas fornece o conhecimento que modela a ação, mas também materiais e enquadramentos que modelam as memórias, aquilo que lembraremos no futuro (ou mesmo no presente) daqueles eventos.

Essa perspectiva do jornalismo de tornar presente o acontecimento contém duas dimensões. Uma dá concretude, materialidade, visibilidade a um evento, travestindo-o com a configuração da notícia. Outra permite que este mesmo evento se transforme no tempo atual. É no hoje que as notícias ocorrem, que o noticiário se desenrola.

0 presente se torna, assim, tanto o assunto quanto o tempo 
da descrição deste assunto. (WEAVER, 1993). O fator tempo define o jornalismo como relatos atuais sobre acontecimentos atuais. Não à toa os manuais clássicos de redação jornalística apregoam que os verbos usados nas manchetes das notícias devem sempre estar no presente, sendo que um bom título sempre contém um verbo. Noticiar é uma ação que se desenrola no presente ao mesmo tempo em que o molda.

Alfredo Vizeu usa o sociólogo e jornalista norte-americano Robert Park, um dos primeiros a estudarem o jornalismo, para destacar esse caráter de atualidade e de instância amarrada ao presente dos relatos noticiosos.

como forma de conhecimento, a notícia não cuida essencialmente do passado nem do futuro, senão do presente - e por isso foi descrita pelos psicólogos como o presente precioso por ser uma mercadoria sumamente perecível. Para o autor, na verdade, a notícia realiza, de certo modo, para o público as mesmas funções da percepção. Ele defende que a função da notícia é orientar o homem e a sociedade num mundo real. (VIZEU, 2005 p.85)

Para além de identificar o presente e determinar os temas da agenda social e das agendas individuais dos cidadãos, os meios de comunicação também trabalham com uma seleção do que merece ser lembrado ou esquecido, reconstruindo o passado.

Ao atualizar o fato, a mídia reconstrói o presente, inscrevendo o que deve ser recordado no futuro - e o que não merece constar do repertório histórico. Essa operação, que sem dúvida importa também em mecanismos ideológicos de ocultação/revelamento de fatos e posições políticas, se dá, curiosamente, por um processo de desorganização da realidade, sob a alegação inversa, de classificar os acontecimentos para melhor apresentá-los ao público. (SANTA CRUZ, 2014). Essa operação também produz uma forma específica de conhecimento da realidade, mediada pelo jornalismo, como aponta Ronaldo Henn:

As pessoas elaboram seus conhecimentos sobre o mundo a partir daquilo que a mídia inclui ou exclui de seu próprio conteúdo. Ao mesmo tempo, a capacidade de influência da mídia sobre o conhecimento daquilo que é importante e relevante varia de acordo com os temas tratados, (HENN, 2006 p.179). 
Além de promover o agendamento destes assuntos, ao atualizar os fatos através de projetos de memória, a mídia também desempenharia um enquadramento - framing - isto é, organizando a realidade dentro de determinados eixos, de modo a permitir o entendimento dos temas.

Os acontecimentos, enquanto notícias, são regularmente interpretados dentro de enquadramentos que derivam, em parte, desta noção de consenso enquanto característica básica da vida quotidiana. São elaborados através de uma variedade de "explicações", imagens e discursos que articulam o que o público supõe pensar e saber da sociedade (HALL, 1993 p. 227).

O enquadramento é, na percepção dos jornalistas, uma ferramenta necessária para reduzir a complexidade de um tema, o que se alinha com as condições de produção das notícias e seu tempo de veiculação. Através de procedimentos como seleção, exclusão ou ênfase de determinados aspectos e informações, os jornalistas operam no processo de significação das notícias e organizam o discurso em circulação na sociedade.

Soares (2012) aponta que o conceito tem origem na obra Frame analysis, do sociólogo norte-americano Erving Goffman (1974), na qual os enquadramentos são definidos como marcos interpretativos construídos socialmente, que permitem às pessoas atribuírem sentido aos acontecimentos e às situações sociais, basicamente, respondendo à pergunta: "O que está acontecendo aqui?". Maurice Halbwachs, sociólogo francês, responsável por introduzir o conceito de memória coletiva nos estudos de memória, até então marcados pelo subjetivismo individual de Henri Bergson, apontou a relação entre framings e memória coletiva. A memória coletiva necessitaria do estabelecimento e da circulação de algum tipo de enquadramento social para que possa operar (HALBWACHS, 1990).

Se o jornalismo fomenta "mapas culturais de significado" (HALL, 1993 p. 225), ele é determinado por uma articulação entre as condições de produção das notícias, a cultura profissional dos jornalistas, a organização do trabalho e as condições de produção. Esta é a perspectiva do Newsmaking, teoria que surge na década de 70 entendendo as notícias 
como construção, na esteira de estudos como $\boldsymbol{A}$ construção social da realidade, dos sociólogos Peter Berger e Thomas Luckmann. A obra discute como a ação subjetiva humana é capaz de criar fatos objetivos que, por sua vez, interferirão na subjetividade dos indivíduos. Assim, a realidade social não é dada, não é natural, mas criada e transformada pela ação humana. O que se designa como realidade social é algo instituído pelos processos de significação, num procedimento ancorado na linguagem. (BERGER e LUCKMAN, 2001). Como a comunicação midiática ocupa lugar de destaque para a organização social, pela veiculação de formas simbólicas representativas culturalmente para os indivíduos, o jornalismo é considerado como uma das principais referências na construção social da realidade contemporânea.

Nelson Traquina (2005) aponta que vários estudos identificam as notícias tanto como operadoras deste processo como resultado dele, mas é o livro de 1978 Making News: A study in the Construction of reality, da socióloga norte-americana Gay Tuchman, resultado de uma pesquisa etnográfica em redações de jornais nos Estados Unidos, que formata as características do Newsmaking.

Entre estas características, estão justamente os processos de produção da notícia. De acordo com a teoria, espera-se que os veículos noticiosos sejam capazes de a) tornar possível o reconhecimento de um fato desconhecido como noticiável; b) elaborar relatos capazes de retirar do acontecimento sua particularidade; c) organizar temporal e espacialmente este conjunto de tarefas transformadoras para que possam ser consumidos.

Diante da imprevisibilidade dos acontecimentos, as empresas jornalísticas precisam colocar ordem no tempo e no espaço, para cumprirem o desafio de apresentar produtos noticiosos dentro de prazos cada vez mais enxutos. Para isso, estabelecem determinadas práticas unificadas na produção de notícias. Convenções de organização do trabalho determinam e definem o que seja notícia e legitimam o processo produtivo.

Desta maneira, a noticiabilidade dos fatos - isto é, sua aptidão 
potencial para se tornarem notícias - está diretamente relacionada com os processos de rotinização e estandardização das práticas produtivas. (WOLF, 1994). Para operacionalizar esse processo de controle e seleção de fatos e produção de notícias, as empresas jornalísticas utilizam critérios de relevância, os valores-notícia. Vizeu chama a atenção para o fato de os valores-notícia estarem

\begin{abstract}
espalhados ao longo de todo o processo de produção, isto é, não estão presentes só na seleção de notícias, mas participam de todas as operações anteriores e posteriores à escolha, embora com um relevo diferente em cada situação. Eles são dinâmicos. Ou seja, mudam em função de aspectos culturais, sociológicos e tecnologias (VIZEU, 2007 p. 225).
\end{abstract}

Os jornalistas, portanto, empregam uma variedade de tipificações no seu trabalho diário - hábitos, rotinas, pressupostos e formas de lidar com o novo. Essas tipificações, que vêm da experiência passada, são uma modalidade de memória. $\mathrm{Na}$ atividade jornalística se consolidam como valores-notícia, os quais, por sua vez, se baseiam no que já foi considerado um valor-notícia no passado. Jeffrey Olick (2014) defende que os valores-notícia são moldados pela memória social e coletiva.

Uma vez que Atualidade e Novidade são dois valores-notícia considerados como critérios de noticiabilidade dos fatos, em que medida o passado retorna como memória e, mais precisamente, como notícia através da atuação dos três centros memorialísticos que esse projeto elege como objetos de estudo? Essa produção não estaria em desacordo com o que afirma Charaudeau: "o acontecimento será selecionado e construído em função de seu potencial de atualidade, de socialidade e de imprevisibilidade"? (CHARAUDEAU, 2006 p. 101). Por outro lado, se considerarmos que os projetos de memória institucional desenvolvidos pelos veículos de comunicação também produzem conteúdo noticioso, portanto jornalístico, a partir do passado, somos levados a questionar como se dá esse agenciamento de acontecimentos não-recentes, porém alçados à condição de novidade, de notícia.

A resposta mais imediata é a que considera "o tempo em si como um objeto de representação e um tema de narrativa" (TENEMBOIM- 
WEINBLATT, 2014 p. 97). Se antes a memória estava reservada para lugares de monumentalização, sua expressão encontra atualmente diversas manifestações. Nas sociedades mediatizadas, os meios de comunicação oferecem, também no que diz respeito aos discursos vinculados ao passado, um lugar privilegiado na disputa dos sentidos. A mídia se assemelha, desta forma, ao conjunto de rituais que permitem a rememoração compartilhada, a qual assimila a pertinência pública da recordação individual. (HALBWACHS, 1990).

\section{Dos arquivos aos centros de memória}

A coleta e a guarda de material produzido periodicamente pelos veículos de comunicação - fossem as fotos utilizadas (ou não) nas edições diárias, os áudios nas rádios, os vídeos nas televisões - já eram objeto de arquivamento. Os órgãos acumulavam estas produções, alguns com mais organização, outros ainda como simples depósito. Era o arquivo, onde eventualmente o repórter se embrenhava para encontrar a fotografia daquela fonte específica ou consultar uma reportagem já veiculada. O Jornal do Brasil foi o pioneiro, em 1964, na implantação de um departamento de pesquisa, que produzia novos conteúdos a partir do material guardado em seu acervo, como conta Alberto Dines, que foi editor-chefe do jornal por 12 anos e responsável pela criação do departamento.

A finalidade do departamento de pesquisa não era somente armazenar informações e pô-las a serviço da reportagem, do copidesque e dos editoriais. Essa versão do research department era adotada então nos grandes jornais americanos. Nossa nota original foi a criação de uma equipe de redatores e consultores de alto nível, aptos a produzir, além do levantamento de dados, material extensivo de apoio para melhor circunstanciar o noticiário. (...) A pesquisa, na sua fase mais criativa, sob a direção do jornalista Roberto Quintaes, passou, assim, a adiantar-se aos acontecimentos, produzindo features no campo da filosofia, ciência, política, estratégia, arte e cultura que tornaram a rubrica famosa em todo o país. (DINES, 2009 p. 90-91)

Ao longo da década de 1980, vários órgãos de imprensa criam seus próprios departamentos de pesquisa, com uma característica mais 
ligada à função de guarda documental para posterior reutilização pelo próprio veículo. A atuação do departamento de pesquisa do JB não irá se constituir numa prática generalizada, mas podemos considerá-lo como o embrião de iniciativas de conservação da memória jornalística que virão a se desenvolver no século XXI, como é o caso do Memória Globo, do Memória do Jornal O Globo, do Acervo do jornal O Estado de São Paulo, da História da Rede de Televisão Record, das Pesquisas Históricas do Jornal do Commercio do Rio de Janeiro e do Acervo Digital da Revista Veja.

O mais antigo de todos eles é o Memória Globo, mantido pela Rede Globo de Televisão, que desde 1999 faz um trabalho de história oral, registrando o depoimento de profissionais que trabalharam ou ainda atuam na emissora, "que, ao falarem sobre suas histórias de vida, com ênfase na trajetória profissional, fornecem elementos para traçar um panorama da história da Globo e da televisão no Brasil" (MEMÓRIA GLOBO, s/d). Em 2008, o projeto ganhou um site, onde disponibiliza diversos materiais audiovisuais e textuais para consulta sobre os programas, coberturas e profissionais da emissora. O Memória Globo não está restrito à produção jornalística, mas compreende também conteúdos de entretenimento.

Outra grande novidade são os webdocumentários que podem ser vistos na página de Vídeos. Trechos de depoimentos e de programas são editados para que o espectador possa assistir a cenas de uma novela inesquecível ou à cobertura de um evento jornalístico que tenha marcado um momento de sua vida. (MEMÓRIA GLOBO, s/d).

Assim, o projeto elabora novos conteúdos a partir dos programas originais, recuperados do passado e atualizados, numa permanente presentificação.

O projeto de Memória do jornal O Globo é um exemplo de recuperação da memória por meio da preservação da história do próprio veículo, como se pode ver pela autodescrição presente no site do projeto, sob o título "O que é memória?"

O projeto Memória O Globo foi criado para resgatar e preservar a história do jornal. Dividido em seções, este 
espaço fornece ao leitor ferramentas adequadas para a pesquisa de temas que, reunidos diariamente nas páginas do Globo, dão a dimensão do jornal como um organismo vivo, que se renova registrando fatos determinantes do dia a dia sejam eles manifestações locais da comunidade, nem por isso desimportantes, ou grandes acontecimentos que marcam a sociedade, provocam mudanças no país e no mundo, alteram o curso da Humanidade. (MEMÓRIA O GLOBO, s/d)

Nessa perspectiva, os meios de comunicação de massa se aproximam do que o historiador francês Pierre Nora (1984) chamou de lugares de memória. Nora sinaliza a necessidade de criação de "santuários de memória" na contemporaneidade. O conceito indica que há lugares onde as pessoas, os grupos sociais ou até mesmo uma sociedade inteira podem ancorar sua memória, face ao fenômeno da aceleração da história que faz com que o presente se torne cada vez mais volátil.

Os lugares de memória nascem e vivem do sentimento de que não há memória espontânea, de que é preciso criar arquivos, manter aniversários, organizar celebrações, pronunciar elogios fúnebres, atas, porque essas operações não são naturais (NORA, 1993, p. 13).

Os lugares de memória seriam signos de reconhecimento e de pertencimento do grupo a uma sociedade. Criados especificamente para conservar uma memória, uma tradição, uma experiência vivida coletivamente, podem ser tanto espaços físicos quanto produções abstratas e rituais.

\section{Considerações finais}

Jornalismo como um agente da história, isto é, como uma instituição social que opera na formatação do fato histórico, é uma abordagem frequente, especialmente no Brasil. Barbosa (2004, 2005, 2007, 2008, 2009, 2012), Casadei (2009, 2010, 2011) e Ribeiro (2003, 2007) são exemplos de pesquisadores brasileiros do campo da Comunicação e/ou do Jornalismo que abordam o tema. André Bonsanto Dias apresenta uma vertente nova no âmbito desses estudos, ao discutir, em o Presente da memória (2014), os usos do passado 
que o jornal Folha de S. Paulo fez para configurar sua identidade no período posterior à ditadura militar até os anos 2000. Christa Berger $(2007,2009)$ analisou os discursos midiáticos em torno da memória a partir de notícias envolvendo a ditadura militar, a repressão, a morte do jornalista Vladimir Herzog, o Vlado.

Essa forte associação entre jornalismo e história, entre fato jornalístico como fato histórico, lança uma pergunta sobre o que significam projetos desenvolvidos por veículos de comunicação com o propósito de recordar.

Estas iniciativas se mostram, simultaneamente, movimentos de valorização da memória e instrumentos de produção de novas versões sobre fatos passados, envolvendo ou não os veículos jornalísticos. Além de funcionarem como resgate e preservação da história dos veículos, reforçando ou estabelecendo uma determinada identidade, elas se firmam como "lugares de memória", no sentido que Pierre Nora imprime à expressão - lugares físicos ou não onde as pessoas, os grupos sociais ou até mesmo uma sociedade inteira podem ancorar sua memória, face ao fenômeno da aceleração da história que faz com que o presente se torne cada vez mais volátil. São espaços de articulação de uma memória coletiva, social, cultural. Bergamo (2011) chama a atenção para o fato de a memória da imprensa se equivaler à memória nacional pela indissociação entre a intensidade do esforço empreendido pelo repórter na cobertura e a importância do evento. Se na cobertura do cotidiano já ocorre essa superposição, em centros de memória jornalística criados com o objetivo de resgate e disponibilização de produtos memorialísticos e memoráveis, esta equivalência adquire um caráter intencional.

Desta forma, percebemos que estes espaços também operam na reconstrução do passado, ou seja, recriam a história e estabelecem novos critérios para definição do que é notícia.

Este não será um espaço fechado, estático, pronto e acabado. Por necessariamente dinâmico, em razão dos incessantes movimentos da sociedade que se traduzem em fatos a serem informados, um jornal se renova a cada dia como veículo 
de comunicação, registrando em suas páginas e diversas plataformas digitais aquilo que se transforma em informação, análise e opinião. Isso implica manter o MEMÓRIA em constante atualização, com o propósito de mostrar ao leitor de amanhã como o jornal terá registrado aquilo que hoje é notícia, e daqui a algum tempo será História (O GLOBO, s/d).

A recriação dos acontecimentos implica, portanto, também num trabalho incessante de urdidura ideológica do real, numa constante construção do cotidiano, operando sobre o senso comum, de maneira performativa, disciplinadora e estabelecendo padrões de normalidade.

Ao cobrir os acontecimentos da atualidade, o jornalismo procede a elaboração de um conhecimento da vida cotidiana reconhecendo o que move a política, a economia, a cultura e, ainda, o que fica na sombra destas grandes temáticas. A mediação da historicidade da vida cotidiana se encontra vinculada ao jornalismo, e é esta condição que alguns cientistas sociais percebem e incorporam em suas tentativas de capturar o tempo presente, incluindo fragmentos jornalísticos para organizar, a partir deles, o argumento que explica que o tempo presente "é assim". (BERGER, TAVARES, 2014 p. 11)

A imprensa se avoca o poder de atribuir o que é notícia ou não. Isso leva a só ser verdade o que está na mídia: um recorte do que lembrar. Huyssen (2000) sinaliza que a mídia não transporta a memória pública inocentemente, ela a condiciona na sua própria estrutura e forma. Lugares de memória, espaços da evocação e de recorte do real.

Ao trazermos o jornalismo para a linha de frente dos estudos de memória coletiva, revelamos o significado do jornalismo como um agente de memória e um repositório da memória compartilhada através do tempo e do espaço.

O jornalismo não apenas cobre as comemorações, ele também as celebra, por exemplo, publicando edições especiais de jornais em ocasiões de aniversário. Ele também tem suas próprias comemorações, por exemplo, celebrando aniversários jornalísticos, como o $20^{\circ}$ ano de um programa noticioso de televisão ou reconhecendo o papel dos pais fundadores do jornalismo, como Edward R. Murrow. (OLICK, 2014 p. 17) 


\section{Referências bibliográficas}

ACERVO ESTADÃO. O Estado de São Paulo. Disponível em < http://acervo. estadao.com.br/>, acesso em 05/02/2016.

AREND, Silvia Maria Fávero; MACEDO, Fábio. Entrevista Sobre a História do Tempo Presente: entrevista com o historiador Henry Rousso, Tempo e argumento. Revista do Programa de Pós-Graduação em História. Florianópolis, v. 1, n. 1, p. 201 - 216 jan. / jun. 2009.

BARBOSA, Marialva. Jornalistas, "senhores da memória". Trabalhoapresentando no Núcleo de Pesquisa de Jornalismo, do IV Encontro dos Núcleos de Pesquisa da Intercom. In: ANAIS do XXVII Congresso Brasileiro de Ciências da Comunicação... Porto Alegre: 2004.

BARBOSA, Marialva. Jornalismo impresso e a construção de uma memória para sua história. In: BRAGANÇA, Aníbal \& MOREIRA, Sônia Virgínia (org.). Comunicação, acontecimento e memória. São Paulo: Intercom, 2005, p.102- 111.

BARBOSA, Marialva. O que a história pode legar aos estudos de jornalismo. In: Contracampo. Revista do Programa de Pós-Graduação em Comunicação - UFF, Niterói $1^{0}$ sem. 2005b, n. 12, pp. 51-63.

BENETTI, Márcia; HAGEN, Sean. Jornalismo e vida cotidiana: o comer e o cozinhar contemporâneos nas revistas semanais. Revista da Associação Nacional dos Programas de Pós-Graduação em Comunicação | E-compós, Brasília, v.11, n.2, maio/ago. 2008. Disponível em www.ecompos.org.br. Acesso em 25jul2015.

BERGER, Christa. Jornalismo e ditadura no Cinema Brasileiro. In: Anais do 5 Encontro Nacional de Pesquisadores em Jornalismo. Aracaju, 2007.

BERGER, Christa. Jornalismo e Memória e Ditadura. In: Anais do $6^{\circ}$ Congresso Sopcom $/ 4^{\circ}$ Congresso Ibérico. Lisboa: Universidade Lusófona de Humanidades e Tecnologias, 2009. Disponível em <http:// conferencias.ulusofona.pt/index.php/sopcom_iberico/sopcom_iberico09/ paper/viewFile/395/390>, acesso em 19/06/2015.

BERGER, Christa; CHAVES, Juliana C.. A contribuição do cinema para a memória da ditadura brasileira. Comunicação e Educação (USP), v. 3, p. 29- 36, 2009.

BERGER, Christa; TAVARES, Frederico de Mello Brandão. Leituras do cotidiano e as interseções entre o Jornalismo e as Ciências Sociais. Contemporânea. v.12 - n.01 - jan-abr 2014 - p. 8-26. Disponível em http://www.portalseer. ufba.br/index.php/contemporaneaposcom/issue/view/823, acesso em 27/07/2015.

BERGER, Peter L. \& LUCKMANN, Thomas. A construção social a realidade: tratado de sociologia do conhecimento. Tradução de Floriano de Souza Fernandes. Petrópolis: Vozes, 2001. 
CANDAU, Joel. Mémoire et identité. Paris: PUF, 1998.

CASADEI, Eliza Bachega. Para além do presente: a inserção do passado nas reflexos sobre o jornalismo. Anais do XXXII Congresso Brasileiro de Ciências da Comunicação. Curitiba, 2009.

CASADEI, Eliza Bachega. Jornalismo e reconstrução do passado. Os fatos históricos nas notícias de hoje. 2010. Dissertação de mestrado em Comunicação - USP, São Paulo.

CASADEI, Eliza Bachega. A evocação à História como estratégia de referencialidade no jornalismo. Anais do XVI Congresso de Ciências da Comunicação na Região Sudeste - São Paulo, 2011.

CHARAUDEAU, Patrick. Discurso das mídias. São Paulo: Contexto, 2006.

CRUZ, Patrícia Monteiro. Discursos da vida real: articulações entre jornalismo e cotidiano na imprensa feminina. Anais do XXXII Congresso Brasileiro de Ciências da Comunicação. Curitiba, 2009.

DIAS, André Bonsanto. O presente da memória. Usos do passado e as (re) construções de identidade da Folha de São Paulo, entre o "golpe de 1964" e a "ditabranda". Jundiaí: Paco Editorial, 2014

DINES, Alberto. O papel do jornal e a profissão de jornalista. 9a edição São Paulo: Summus Editorial, 2009.

FRANCISCATO, Carlos Eduardo. A fabricação do presente. São Cristóvão: UFS, 2005.

GENRO FILHO, Adelmo. O segredo da pirâmide. Florianópolis: Insular, 2012.

HALBAWCHS, Maurice. A memória coletiva. São Paulo: Vértice, 1990.

HALL, Stuart et al.. A produção social das notícias: o mugging nos media. In: TRAQUINA, Nelson (org.). Jornalismo: questões, teorias e "estórias". 2. ed. Lisboa: Vega, 1993. p. 224-248.

HENN, R. Direito à memória na semiosfera midiatizada. Revista Fronteiras, São Leopoldo: Unisinos, 2006.

HUYSSEN, Andreas Mídia e discursos da memória. Entrevista de Moreira, Sonia Virgínia e Moreno, Carlos A. de Carvalho Moreno. In Revista Brasileira de Ciências da Comunicação. No 1- 2004: Intercom, p-97-104.

HUYSSEN, Andreas. "Medios y memoria" en Feld, Claudia y Stites Mor, Jessica (comp.) El pasado que miramos, Editorial Paidós, Buenos Aires, 2009.

HUYSSEN, Andreas. Culturas do passado-presente. Modernismos, artes visuais, políticas da memória. Rio de Janeiro: Contraponto/Museu de Arte Moderna, 2014.

HUYSSEN, Andreas. Seduzidos pela Memória. Rio de Janeiro: Aeroplano, 
2000.

MADUELL, Ítala. Revista Brasileira de História da Mídia (RBHM) - v.4, n.1, jan./2015 - jun./2015, p. 31-39.

MAROCCO, Beatriz; BERGER, Crista (Orgs.) A Era Glacial do Jornalismo: teorias sociais da imprensa. Porto Alegre: Sulina. v. 1 (2006).

MCCOMBS, Maxwell e SHAW, Donald. The Agenda-Setting Function of Mass Media. The Public Opinion Quaterly, Vol. 36, no 2 (Summer, 1972), p. 176- 187.

MEMÓRIA GLOBO. Disponível em <http://memoriaglobo.globo.com/>, acesso em 19/03/2015.

MEMÓRIA JORNAL O GLOBO. Disponível em <http://memoria.oglobo.globo.

com/>, acesso em 20/03/2015.

MORETZSOHN, Sylvia. Pensando contra os fatos. Jornalismo e cotidiano: do senso comum ao senso crítico. Rio de Janeiro: Revan, 2007.

MOTTA, Luiz Gonzaga. Para uma antropologia da notícia. In: Revista Brasileira de Ciências da Comunicação. Vol. XXV, $n^{\circ} 2$, julho/dezembro de 2002.

NORA, Pierre. Entre memória e história: a problemática dos lugares. Trad. Yara Khoury. Projeto História, São Paulo: Revista do Programa de Estudos Pós-Graduados em História e do Departamento de História da PUC/ SP, n.10, p.7-28, dez. 1993.

NORA, Pierre. Les lieux de mémoire. Paris, Gallimard, 1984 O GLOBO. Jornal recupera e relata seus 88 anos de história. Rio de Janeiro, 1/9/2013. P.14.

O GLOBO. Apoio ao golpe de 64 foi um erro. Rio de Janeiro, 1/9/2013, p. 15.

OLICK, Jeffrey. Reflections on the underdeveloped relations between Journalism and Memory Studies. In ZELIZER, Barbie \& TENENBOIM-WEINBLATT, Karen. Journalism and Memory. Memory Studies. London: Palgrave Macmillian, 2014.

POLLAK, Michel Memória, esquecimento, silêncio. Estudos Históricos, Rio de Janeiro, v. 2, n. 3, p. 3-25, 1989.

POLLAK, Michel. Memória e identidade social. Estudos Históricos, Rio de Janeiro, v. 5, n. 10, p. 200-212, 1992.

RIBEIRO, Ana Paula Goulart. A mídia e o lugar da história. In: HERSCHMANN, Carlos \& PEREIRA, Carlos Alberto Messeder. Mídia, memória e celebridades - estratégias narrativas em contextos de altas visibilidades. Rio de Janeiro: E-Papers, 2003, p.87-111. 
RIBEIRO, Ana Paula Goulart; BARBOSA, Marialva. Memória, relatos autobiográficos e identidade institucional. Comunicação \& Sociedade, v. 47,p. 99-114, 2007.

RIBEIRO, Ana Paula Goulart. A história oral nos estudos de jornalismo: algumas considerações teórico-metodológicas. In: Revista Contracampo, v. 32, n. 2, ed. abril-julho ano 2015. Niterói: Contracampo, 2015. Págs.: 7390.

RIBEIRO, Beliza. JB Memória. Disponível em <http://www.jbmemoria.com. $\mathrm{br} />$, acesso em 19/03/2015.

SANTA CRUZ, Lucia. Pedagogia do jornalismo: narrativa e responsabilidade social na tela da tv. Revista Latinoamericana de Ciencias de la Comunicación, Ano IX - vol.9 no 2 - Edição 17, p. 216-226, 2012.

SANTA CRUZ, Lucia. O repórter como historiador do tempo presente. In: PEREIRA, Carlos Alberto Messeder, ASSIS, Francisco de e ANTONIOLI, Maria Elisabete. Desafios do Jornalismo: novas demandas e formação profissional. Curitiba: Appris, 2014

SODRÉ, Muniz \& FERRARI, Maria H. Técnica de reportagem. São Paulo: Summus, 1986

SARLO, Beatriz. Tempo passado. São Paulo, Belo Horizonte: Companhia das Letras, UFMG, 2005.

SCHEUFELE, Dietram A. \& TEWKSBURY, David. Framing, Agenda Setting, and Priming: The Evolution of Three Media Effects Models. Journal of Communication 57 (2007) 9-20 a 2007 International Communication Association, 2007.

SHAW, Eugene F. Agenda-Setting and Mass Communication Theory. International Communication Gazette, May 1979, 25:96-105.

SOARES, Murilo Cesar. Análise de enquadramento. In: DUARTE, Jorge e BARROS, Antônio (org.) Métodos e técnicas de pesquisa em Comunicação. $2^{a}$ edição. São Paulo: Atlas, 2012. Material complementar. Disponível no site https://www.editoraatlas.com.br/atlas/webapp/detalhes_produto.aspx?prd_ des_ean13=9788522474400\#ancMaterial

TENEMBOIM-WEINBLATT, Keren. Counting time: journalism and the temporal resource. In ZELIZER, Barbie \& TENENBOIM-WEINBLATT, Karen. Journalism and Memory. Memory Studies. London: Palgrave Macmillian, 2014

TRAQUINA, Nelson. Teorias do jornalismo: porque as notícias são como são. Vol. 1. Florianópolis: Insular, 2005, 2a edição.

VIZEU, Alfredo. O newsmaking e o trabalho de campo. In LAGO, Cláudia e BENETTI, Marcia. Metodologia de pesquisa em jornalismo. $3^{a}$ edição. Petrópolis: Vozes, 2007.

VIZEU, Alfredo. Telejornalismo: o conhecimento do cotidiano. Estudos em Jornalismo e Mídia, vo. II, n² - $2^{\circ}$ semestre de 2005. 
VIZEU, Alfredo. Decidindo o que é notícia: os bastidores do telejornalismo Porto Alegre: Editora da PUC-RS, 2003

WEAVER, Paul. As notícias de jornal e as notícias de televisão. In: TRAQUINA, Nelson (Org.). Jornalismo: questões, teorias e 'estórias'. Lisboa: Vega, 1993. p. 294-305. 


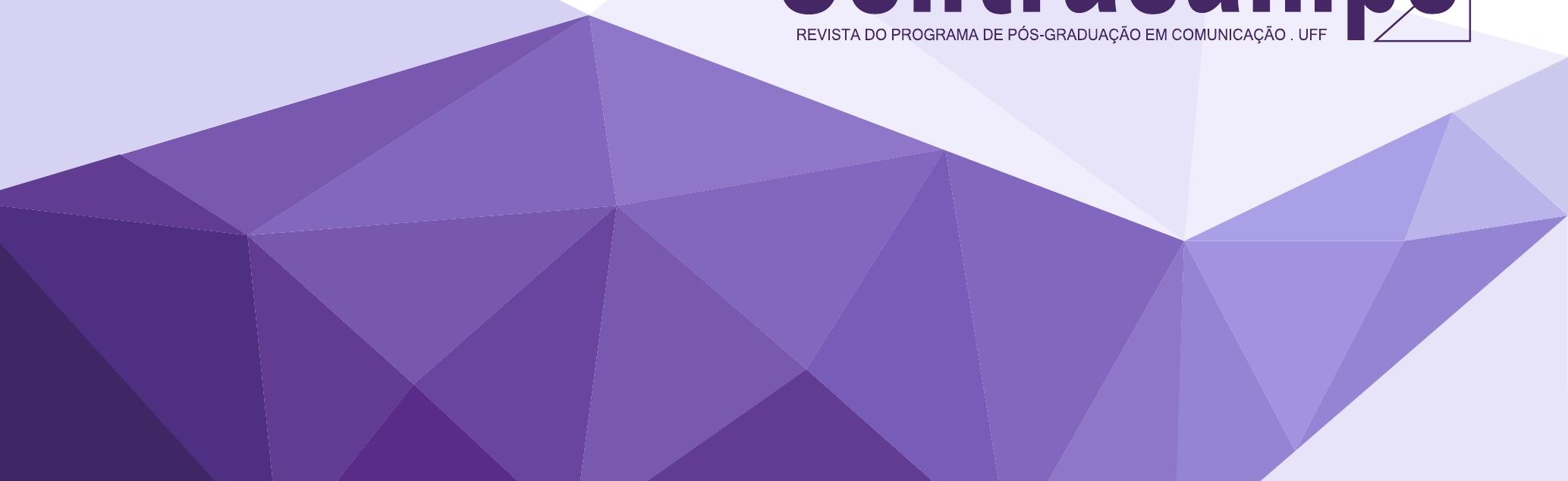

MEMÓRIAS EM DISPUTA NA COBERTURA DO CASO SNOWDEN A REINVENÇÃO DA AUTORIDADE
JORNALÍSTICA NA ERA DIGITAL

DISPUTED MEMORIES IN SNOWDEN CASE COVERAGE REINVENTING JOURNALISTIC
AUTHORITY IN THE DIGITAL AGE

Edição v.35 número 3 / 2016-17

Contracampo e-ISSN 2238-2577 Niterói (RJ), v. 35, n. 3 dez/2016-mar/2017

A Revista Contracampo é uma revista eletrônica do Programa de Pós-Graduação em Comunicação da Universidade Federal Fluminense e tem como objetivo contribuir para a reflexão crítica em torno do campo midiático, atuando como espaço de circulação da pesquisa e do pensamento acadêmico.

\section{ANA PAULA GOULART RIBEIRO}

Formada em jornalismo pela Universidade Federal Fluminense (1990), tendo também cursado história na mesma instituição. Fez mestrado (1995) e doutorado (2000) em Comunicação e Cultura na Universidade Federal do Rio de Janeiro. É professora da Escola de Comunicação da UFRJ e coordenadora do Programa de PósGraduação. Suas áreas de interesse e pesquisa são mídia, memória e história dos meios de comunicação. Atualmente, desenvolve as pesquisas "Imprensa e Mercado no Brasil: de 1945 aos anos 2000" e "História da Mídia e Itinerância das Imagens". Coordena o projeto "Memória do Jornalismo Brasileiro". Brasil.

\section{RACHEL BERTOL}

Doutora em Comunicação e Cultura pela Universidade Federal do Rio de Janeiro (2016). Realizou Doutorado Sanduíche na Universidade de Princeton, nos EUA, entre setembro de 2014 e fevereiro de 2015. Bolsista da Fundação Biblioteca Nacional (2015-2016), integrando o Programa Nacional de Apoio à Pesquisa (Pnap), e pesquisadora do Núcleo de Estudos e Projetos em Comunicação (Nepcom-UFRJ), atuando no projeto Memória do Jornalismo Brasileiro, sob orientação da Professora Doutora Ana Paula Goulart Ribeiro. Possui graduação em Comunicação Social (jornalismo) pela UFRJ (1993) e Mestrado em Comunicação e Cultura pela mesma universidade (2003). Brasil.

\section{PPG|COM compention UFF}

AO CITAR ESTE ARTIGO, UTILIZE A SEGUINTE REFERÊNCIA:

RIBEIRO, Ana Paula Goulart; BERTOL, Rachel. Memórias em disputa na cobertura do caso Snowden. A reinvenção da autoridade jornalística na era digital. Contracampo, Niterói, v. 35, n. 03, dez. 2016/ mar. 2017. 


\section{Resumo}

A cobertura jornalística do caso Snowden, que vazou documentos revelando a espionagem realizada pelo governo americano, é analisada neste trabalho a partir do conceito de incidente crítico (estabelecido por Zelizer), para a reconfiguração da autoridade jornalística. A partir do confronto de narrativas de memória, os jornalistas renegociam sua autoridade e estabelecem visões dominantes da história. O caso propiciou a formação de uma "comunidade interpretativa" que recriou um ideal profissional mesclando antigos paradigmas com elementos novos das práticas nas mídias digitais. A memória, especialmente em sua dimensão coletiva, é analisada a partir de conceitos sobre arquivamento, fragmentação e globalização. $O$ caso mostra que as conexões entre memória e jornalismo adquiriram novos significados em relação ao que se estabeleceu na Modernidade.

\section{Palavras-chave}

autoridade jornalística; memória coletiva; Edward Snowden

\section{Abstract}

The press coverage of Snowden's leaking of classified documents about the done by the US government espionage is analyzed in this work as a "critical incident", a concept (as established by Zelizer) for the reconfiguration of journalistic authority. The event has inspired different retellings by the journalists involved through which they renegotiated their authority and dominant versions of the story itself. The case led to the creation of an "interpretive community" which reinvented a professional ideal mixing old paradigms with new elements belonging to the practices of digital media. Memory, especially in its collective dimension, is analyzed from concepts of archiving, fragmentation and globalization. The case shows that memory connections with journalism have acquired new meanings in relation to what was established in Modernity.

\section{Keywords}

journalistic authority; collective memory; Edward Snowden 


\section{After Snowden: introdução}

O caso Edward Snowden, que vazou para a imprensa em 2013 documentos confidenciais sobre a espionagem realizada pelos Estados Unidos, é analisado neste artigo a partir do conceito de "incidente crítico" desenvolvido pela teórica americana Barbie Zelizer (1992). Trata-se de incidente que propicia aos jornalistas acessar e renegociar o significado de sua atividade, enquanto comunidade interpretativa, na medida em que buscam se afirmar como voz privilegiada sobre o caso. Pelo confronto entre diferentes narrativas de memória, o incidente crítico leva à reconfiguração da autoridade jornalística, redefinindo parâmetros da prática da profissão. Desse modo, observase a performance da mídia na contemporaneidade para a conformação de versões memoráveis do passado.

Dois anos depois de o caso vir à tona - a primeira reportagem foi publicada em 5 de junho de 2013 pelo jornal britânico The Guardian diferentes livros e o documentário Citizenfour, dirigido pela americana Laura Poitras, premiado em 2015 com o Oscar, formam uma ampla coleção de narrativas a respeito. O próprio Snowden, embora radicado em Moscou, costuma participar de debates pela internet, como no lançamento em março de 2015 o Snowden Surveillance Archive $^{1}$ no Canadá. São ocasiões em que relembra o acontecimento e reitera os significados de sua decisão de tornar públicos os documentos da Agência Nacional de Segurança (NSA, na sigla em inglês). A demanda por sua presença, mesmo que virtual, indica o quanto sua versão é valorizada, certamente em detrimento de outras.

O arquivo foi criado pela organização não governamental Canadian Journalists for Free Expression (CJFE). Reúne todos os documentos (cerca de 400) já publicados por veículos de comunicação do conjunto passado por Snowden à imprensa. Também foram postas no site centenas de reportagens sobre as ações de espionagem.

O fato de o Snowden Archive ser realizado por uma organização

1 http://snowdenarchive.cjfe.org e http://cjfe.org/blog/snowden-live-canada-and-security-state 
que trabalha em prol da liberdade de expressão jornalística, e ter o intuito de se tornar uma referência internacional, indica o quanto o episódio se tornou relevante para a causa. Há um duplo significado em associá-lo à ideia da liberdade ou afirmação da expressão jornalística.

Em primeiro lugar, a natureza do seu conteúdo constitui um desafio à liberdade de expressão: como pode o jornalismo se desenvolver plenamente sob permanente vigilância? Em 5 de fevereiro de 2015, o Tow Center for Digital Journalism, da Universidade de Colúmbia, promoveu em Washington o encontro final da série Journalism after Snowden, que vinha desenvolvendo há um ano. O evento reuniu, entre outros, os editores-chefes dos jornais The New York Times, The Washington Post e do site Politico.

Uma das principais conclusões de Colúmbia aponta para a necessidade de os jornalistas e suas organizações se aparelharem cada vez mais para o uso da criptografia. Não por acaso é com referência à necessidade de segurança da informação que o jornalista americano Glenn Greenwald abre seu livro Sem lugar para se esconder (2014), sobre seu trabalho no caso: no fim de 2012, em sua casa no Rio de Janeiro, ele recebeu o pedido insistente de um desconhecido que se apresentava como Cincinnatus, para que instalasse em seu computador programas de segurança a fim de conversarem.

No entanto, mais importante ainda para os jornalistas que o alerta sobre a segurança, por si relevante, foi a maneira como ocorreu a cobertura, enquanto incidente crítico que reconfigura a autoridade jornalística. Esse processo inclui as narrativas memoráveis dos jornalistas ou retellings, nos termos de Zelizer. Foi pelo modo como se deu a cobertura, e como esta se constituiu pelos diferentes relatos posteriores, que o caso se tornou simbólico para organizações como o Canadian Journalists for Free Expression ou para a Universidade de Colúmbia.

Os diferentes sentidos da expressão "after Snowden", presente no estudo da universidade americana no que se refere ao jornalismo e no título do livro do sociólogo David Lyon, Surveillance after Snowden 
(2015), indicam o quanto o episódio se tornou um marco, a ponto de se falar de um antes e um depois. Para Lyon, que pesquisa há cerca de 30 anos questões de vigilância, Snowden também propicia a afirmação de sua linha de pesquisa².

Numa época em que a coleta e a estocagem de dados é cada vez mais praticada por governos, Snowden (e com ele o jornalismo) toca no cerne do poder. Os diferentes prêmios recebidos pelos profissionais envolvidos na cobertura - Gleenwald se tornou o primeiro estrangeiro a ganhar o Prêmio Esso no Brasili, passando a integrar a história do jornalismo brasileiro - são indícios de quais personagens detêm as versões memoráveis. Confrontos de versões, que envolvem especialistas em segurança e jornalistas, novos tipos de profissionais (como Greenwald, advogado de formação e inicialmente blogueiro) e aqueles mais tradicionais, formam a colcha de retalhos que propicia a construção de narrativas dominantes (ZELIZER, 1992, p. 31).

A análise de Zelizer sobre os relatos do assassinato de John F. Kennedy, desde o primeiro impacto até os desdobramentos 30 anos depois, mostra como as versões jornalísticas disputam entre si para se impor como dominantes. Também concorrem com as de outros grupos profissionais, como de pensadores independentes e historiadores. O estudo sobre a morte trágica de Kennedy torna-se, assim, "um exemplo estrategicamente escolhido" (p. 11) para observar a presença da autoridade jornalística. "Os padrões de autoridade pelos quais a história do assassinato foi recontada podem funcionar como protótipo para o estudo de diferentes relatos (retellings) realizados pela mídia a respeito de outros eventos" (idem). Este artigo se desenvolve nesse sentido.

A análise do caso Snowden enquanto incidente crítico toma

2 Na edição de 2015 da conferência da International Association for Media and Communication Research (IAMCR), realizada em Montreal, entre 12 e 16 de julho, Lyon proferiu palestra sobre vigilância. Lembrou seu pioneirismo nas pesquisas na área, sem abordar questões de jornalismo. Questionado sobre como via o jornalismo sob a perspectiva de Snowden, destacou a necessidade de os jornalistas trabalharem cada vez mais em colaboração com os cientistas sociais (de certa forma, sua fala evidencia uma disputa por autoridade no sentido aqui apresentado).

3 A série de reportagens Na mira dos EUA, de José Casado, Roberto Kaz e Glenn Greenwald, publicada entre 7 e 9 de julho de 2013, rendeu ao jornal $O$ Globo o Prêmio Esso de Reportagem daquele ano. 
como base os livros Sem lugar para se esconder (2014), de Glenn Greenwald, e The Snowden Files (2014) ${ }^{4}$, de Luke Harding, publicado na Grã-Bretanha pelo jornal The Guardian, além do filme Citizenfour, de Laura Poitras, e de depoimentos de Barton Gellman, o jornalista do Washington Post que também obteve em primeira mão acesso aos documentos. Gellman e Greenwald ganharam o Pulitzer por sua cobertura do caso.

Há uma quantidade muito maior de material que poderia ser analisada, algo impossível neste espaço. Além disso, muito ainda se escreverá e produzirá a respeito. No fim deste ano, está previsto o lançamento do filme Snowden, de Oliver Stones. Não deixa de ser outro ponto de contato com o trabalho de Zelizer, que dedica em seu estudo muitas páginas a JFK, do mesmo diretor. Lançado quase 30 anos depois do assassinato, a película renovou o debate e as disputas por autoridade interpretativa. A ironia dos tempos é que agora a reconstituição ficcional no cinema chega apenas dois anos depois, sinal de aceleração ainda maior na circulação da cultura.

Antes da análise dos retellings, entretanto, deve-se observar o que se entende por memória, especialmente a função da mídia na composição de tramas do passado. A perspectiva do incidente crítico evidencia o papel do jornalismo na construção do processo histórico.

\section{Mídia e amnésia}

A hipótese (utopia ou metáfora) do arquivo total, sem delete verdadeiramente possível, ganha novas conotações com Snowden. A espionagem seria o motor de construção desse arquivo, e não mais o medo do esquecimento. A ironia, expressa em afirmações como a de Huyssen - "a ideia do arquivo total faz os triunfalistas do ciberespaço abraçar fantasias globais à la McLuhan" (2003, p. 20) -, cede agora mais espaço à desconfiança.

O arquivamento, na lógica digital, é "a tradução do evento em

4 Há uma versão do livro para português, publicada também em 2014, cujos trechos destacamos.

5 Anunciado para o fim de 2015, o filme estreou no Brasil no fim de 2016. 
informação cifrada e localizável dentro de um sistema" (COLOMBO, 1986 , p. 18). A possibilidade da tradução em linguagem binária de cada fragmento de um banco de dados permite que todo aspecto do mundo seja "legível em caracteres alfanuméricos" (idem). Assim, os bancos de dados são "tendencial e essencialmente - arquivo do mundo, porque predispostos a recolher todo o seu devir, a lógica arquivística [...] prescinde de qualquer seleção a priori que não seja a da traduzibilidade" (p. 92). Nos anos 1980, Colombo havia escrito que "o mito da clavis universalis, da linguagem universal única, suscetível de exprimir toda e qualquer realidade, parece encontrar no universo eletrônico um surpreendente renascer, desta vez em função arquivística" (idem). Mas o triunfalismo que associava ao potencial do arquivo digital também cede lugar agora a algo mais sombrio.

A tradução, no arquivo digital, prescinde a função seletiva da memória: tudo pode ser armazenado. De acordo com Colombo, vivese sob uma "obsessão social que detesta o esquecimento e remove o esquecido como uma inquietante prova da impossibilidade de um arquivamento totalizante" (p.103). A compulsão por tudo guardar reforça a ideia de memória arquivística. As formas de obsessão mnemônica se sujeitam à lógica da cultura contemporânea, impregnando não só o processo de culturalização coletiva, mas a vida cotidiana, os modos de pensar, as conviç̧ões pessoais e de grupo.

Para Huyssen, o fim do século XX e início deste é marcado por culturas do "passado presente", com o desejo por narrativas do passado e suas "re-criações, re-leituras, re-produções" (2003, p. 5), o que leva a uma "sedução do arquivo" como local privilegiado de preservação temporal e espacial. O "passado presente" opõe-se ao "futuro presente" do início do século $\mathrm{XX}$, com suas promessas positivistas. Diante do ritmo cada vez mais acelerado de mudanças, que leva à compressão da percepção de tempo-espaço, há um "boom de memória". A mídia torna-se central: "Não podemos discutir a memória pessoal, geracional ou pública de forma separada da enorme influência da nova mídia como portadores de todas as formas de memória" (p. 18). 
Antes que se possa associar tal ideia à noção de "lugar de memória" de Nora (1984), Huyssen estabelece um contraponto. Não seria possível imaginar a existência de lugares que possam funcionar como encarnações de uma memória sobrevivente, com sentido compensatório. Este seria um argumento conservador: em vez da ideia de perda contida no movimento de compensar, o importante seria reconhecer o deslocamento fundamental nas estruturas de sentimento, experiência e percepção que caracteriza o presente e se difunde pelo tecido social.

Se existe um evidente processo que chama de "musealização", este é sugado no "cada vez mais veloz redemoinho de imagens, espetáculos e eventos e, portanto, está sempre em perigo de perder sua capacidade de garantir estabilidade cultural ao longo do tempo" (p. 24). A ideia de um passado seguro, que poderia explicar o presente e fornecer sentidos ao futuro, é assim constantemente posta em xeque. A relação entre memória e esquecimento, que se dá pelas mídias, muitas vezes ocorre por intermédio de memórias imaginadas, não vividas, fáceis de serem descartadas. Huyssen se pergunta se ao boom de memória não haveria um correspondente boom de esquecimento ( $p$. 17).

No entanto, sem querer se associar ao que chama de pessimismo adorniano, contra a lógica da indústria cultural, ou otimismo benjaminiano em relação ao potencial da reprodutibilidade, Huyssen indica que o exercício da memória nem sempre banaliza o passado. Os casos variam de acordo com os contextos e as estratégias específicas de representação acionadas para cada um. Portanto, deve-se "discriminar entre práticas de memória" (p. 10), a fim de não sucumbir ao que chama de "hipertrofia da memória" ou "alegria da amnésia".

Os "discursos de memória" teriam como função tornarem-se plataformas para imaginar futuros. Nessa perspectiva, está em jogo a compreensão sobre como amnésia e memória podem coexistir e se relacionar, ou seja, como a sociedade e os diferentes grupos sociais fazem a gestão da sua memória e do seu esquecimento. Há uma 
indústria da nostalgia e da comemoração alimentada pela mídia, que engloba os meios jornalísticos.

Discriminar, tal como sugere Huyssen, as "práticas de memória" relacionadas ao jornalismo implica observar o sentido das práticas de memórias no grupo (o de jornalistas), que ao compartilharem experiências situam-se no âmbito da memória coletiva - Zelizer, em sua definição clássica para os jornalistas, define tal prática compartilhada pela expressão "comunidade interpretativa". Para Huyssen, as concepções fundadoras de Halbwachs (1990) não seriam mais adequadas para lidar com a memória coletiva, pois apresentam formações relativamente estáveis de memórias sociais ou de grupos, sem dar conta das dinâmicas atuais da mídia e da temporalidade (2003, p. 17).

Hoje, teríamos políticas de memória cada vez mais fragmentadas, entre grupos étnicos ou sociais, a ponto de Huyssen duvidar se ainda seria possível haver formas consensuais de memória coletiva (idem). Diante dessa provável impossibilidade, ele pergunta - e talvez seja seu principal questionamento - se ainda há meios de garantir coesão social. "A memória da mídia sozinha não será suficiente, embora a mídia ocupe fatias cada vez mais maiores das percepções sociais e políticas do mundo" (idem).

Sua crítica ao trabalho pioneiro de Halbwachs se associa também à influência deste para a formulação de conceitos como o de "lugar de memória" de Nora (p. 96), no sentido de que esse lugar surgiria somente quando a memória coletiva perde sua força (para compensá-la, conforme vimos). No entanto, além de sua crítica à ideia de compensação, um segundo ponto de objeção a Nora - e que permite retomá-lo em outra chave - é sua ênfase na ideia de memória nacional. Isso porque Huyssen diz estar interessado nas interseções da dimensão global com aquela nacional ou local em seus movimentos de constituição de espaços de memória. Seu objetivo é a construção de um "campo expandido" (p. 97), que envolve ir além de limites préestabelecidos, tomando como ponto de partida a arte, mas também 
a relação com a geografia, a política e os discursos traumáticos das próprias memórias a partir da perspectiva de Nora: "Nesse sentido, os lugares de memória hoje funcionam não apenas como um campo expandido mas como um campo alterado pela globalização" (idem).

A ideia de campo alterado pela globalização pode ser transposta ao jornalismo. "Numa era de domínios performativos cada vez mais misturados, de narrativas recicladas" (ZELIZER e TENENBOIMWEINBLATT, 2014), em ambientes onde não é possível a localização clara num ponto do tempo e nos quais a informação parece vir de qualquer lugar, o jornalismo obedece a novos parâmetros temporais e espaciais. Há até pouco tempo, a própria atividade se mantinha fechada, "resistindo a ir além do tópico, do novo, do instantâneo" (idem), resistindo à reflexão, como estratégia para se manter distinta, como diz Zelizer, ou autônoma.

Compreender as relações entre jornalismo e memória torna-se importante não apenas para conhecer "as complexas nuanças temporais" que envolvem a produção das notícias, como "o papel central do jornalismo como repositório primário da memória coletiva em toda sociedade na qual ele se encontra" (idem). Dessa forma, questiona-se a função do jornalismo na Modernidade. Para Zelizer, três palavras gravação, armazenamento, recuperação (recording, storage, retrievel) - evidenciam a interconexão de práticas entre os dois campos (o da memória e o do jornalismo).

A invenção da imprensa permitiu à memória se relacionar mais diretamente com a materialidade. De seu lado, o jornalismo integrou na Modernidade "os valores positivistas da imparcialidade, do equilíbrio e da razão, opostos à ideia vigente de memória, como individual, fluida e incerta", destaca Caldeira (2014) em resenha sobre a coletânea Journalism and memory co-organizada por Zelizer. Na Modernidade, segundo esta teórica americana, "onde a memória falhou, o jornalismo prevaleceu".

Outra característica comum aos dois campos é a narratividade, cuja importância Halbwachs já destacava para a memória, 
embora continue a haver poucos estudos cruzados a respeito. Ora, "desde pelo menos os anos 1980, o jornalismo é a instância que trabalha precisamente os objetos dos estudos de memória: testemunho, trauma, guerra, luto" (CALDEIRA, 2014). São objetos que têm a narratividade como matéria.

A respeito das narrativas do caso Snowden será preciso observar em que medida a disputa por autoridade interpretativa que ensejam os jornalistas - e que constitui um trabalho de constituição de memória coletiva - ainda poderia ser vista pelo viés de uma "comunidade interpretativa", conceito utilizado por Zelizer para analisar os retellings da morte de Kennedy.

Lidar com a memória coletiva, destaca a autora, significa ampliar o debate para as instituições envolvidas nessas relações. "Na medida em que a política, o mercado, a educação, a religião começaram a figurar na transformação da lembrança individual para a coletiva, o jornalismo não fez parte disso" (ZELIZER, 2014).

\section{A 'fonte virgem'}

Os retellings do caso Snowden evidenciam que se trata de um momento de disputa por autoridade interpretativa no ambiente de transição do jornalismo impresso para o das novas mídias.

Tecnologia é a palavra-chave em diferentes sentidos: a espionagem em ampla escala dos cidadãos só é possível devido aos recursos do digital. Portanto, a tecnologia, em última instância, forneceu o conteúdo das reportagens. Além disso, os jornalistas e os jornais travaram um duro corpo-a-corpo com a tecnologia. No início, para realizar os primeiros contatos com a fonte, que exigia criptografia; depois para entender os códigos dos documentos; por fim, para proteger os dados ainda não divulgados.

Foi ainda em torno da tecnologia que se deram as disputas de autoridade interpretativa. O caso Snowden reafirma o valor da atividade jornalística num momento em que esta se encontra desacreditada 
diante das novas formas de circulação da informação propiciadas pela tecnologia. Não se trata de separar em lados distintos, preto no branco, diferentes tipos de jornalismo, mas de observar as passagens entre um e outro, suas idas e vindas, presentes nas narrativas de memória (retellings) sobre o caso, e que redefinem a prática.

No caso específico dos EUA, ainda, cumpriu a função de buscar restabelecer, em alguma medida, parâmetros de independência diante do Estado: o governo de Barack Obama vinha promovendo ingerências à ação de jornalistas ${ }^{6}$, numa continuidade e até aprofundamento de práticas iniciadas depois do 11 de Setembro - este outro "incidente crítico" de grande proporção para o jornalismo7 e ao qual as ações de espionagem em larga escala se conectam. O caso Snowden também fez com que se demarcassem linhas de diferenciação entre o jornalismo americano e o britânico.

Em seu estudo clássico, Zelizer destaca que a morte de Kennedy propiciou à televisão, na época um meio de comunicação ainda novo, conquistar espaço diante do público. Os jornalistas televisivos conseguiram sobrepor sua voz, inclusive em detrimento do ideal do repórter investigativo, com destaque para valores como o da "testemunha ocular". Fazer prevalecer sua versão era sinal de autoridade interpretativa, obtida na medida em que se consolidava a autoridade profissional. A tecnologia mostrou-se central nas disputas narrativas. Com Snowden, houve algo semelhante, mas em relação às mídias digitais.

Busca-se analisar o que esteve em jogo nos primeiros momentos da cobertura. Marcar território na disputa de narrativas memoráveis foi algo que os personagens envolvidos viram como urgente. $O$ fato de Laura Poitras ganhar o Oscar de 2015 e outros prêmios por Citizenfour (no qual Greenwald e a própria diretora são personagens destacados)

6 Gleenwald e Harding destacam o momento difícil do jornalismo nos EUA na época em que Snowden deu à imprensa os documentos, como exemplificam os casos dos jornalistas da Associated Press que tiveram sua comunicação interceptada, na tentativa de localizar uma fonte, e do jornalista da Fox News, James Rosen, que “os advogados do governo diziam ser 'cúmplice de conspiração' nos delitos cometidos pela fonte, uma vez que ele obtivera material confidencial" (GREENWALD, 2014, p. 129).

7 Ver Journalism After September 11 (2011), organizado por Zelizer e Stuart Allan. 
fez com que obtivesse ampla atenção da mídia e se tornasse um importante documento sobre o caso.

The Guardian, de seu lado, realizou um trabalho intenso para publicar, em fevereiro de 2014, um alentado livro-reportagem a respeito. Escrita pelo jornalista da casa Luke Harding ${ }^{8}$, a obra, de cerca de 300 páginas, tornou-se uma narrativa importante para o roteiro do filme de Oliver Stone. Greenwald também escreveu sua versão. Diferentemente dos livros de oportunidade feitos a toque de caixa, nesses era preciso contar o quanto antes suas memórias para reforçar a competência e a autoridade.

Barton Gellman, do Washington Post, escreve para a Penguin um livro sobre questões de segurançå ${ }^{9}$. A maneira como a obra poderá ser lançada, por uma editora importante, tem potencial para impacto no conjunto de retellings. $\mathrm{Na}$ internet é possível ter acesso a depoimentos seus sobre a cobertura. Professor visitante em universidades de prestígio nos EUA, Gellman costuma ser requisitado em espaços nobres para a formação da opinião pública americana. São lugares para os quais os jornalistas do Guardian talvez não sejam convidados com a mesma frequência. Sua autoridade é reforçada com o respaldo dessas instituições.

As primeiras tentativas de contato de Snowden com a imprensa começaram no fim de 2012. Greenwald foi o profissional escolhido por ele. Advogado de formação, autor de livros que abordam questões de vigilância pós-11 de Setembro, ele mantinha desde 2005 um blog sobre esses temas. Quando foi procurado por Snowden era colunista do Guardian. O fato de não se tratar de um jornalista tradicional teria sido um fator de confiança, conforme conta, "(...) para não recuar ante a pressões do governo e de seus muitos aliados na mídia e em outras áreas" (2014, p.11). Sua inserção no jornalismo se deu pelo exercício da opinião, e não pelo caminho mais comum da reportagem.

8 Também autor, com David Leigh, de Wikileaks: Inside Julian Assange's War on Secrecy, igualmente editado pelo jornal The Guardian.

9 Dark Mirror: Edward Snowden and the American surveillance state (Penguin), de Barton Gellman, com 400 páginas, tem lançamento previsto para 6 de junho de 2017. 
Em várias ocasiões, Snowden explicou que desde o início desejava o envolvimento de Laura [Poitras] e o meu nas matérias, pois sabia que daríamos as notícias de forma agressiva, sem nos deixar intimidar por ameaças do governo. Citou muitas vezes o New York Times e outros veículos importantes que haviam segurado matérias grandes a pedido do governo. No entanto, embora desejasse uma divulgação agressiva, ele queria também jornalistas meticulosos, que levassem todo o tempo necessário para garantir que os fatos ficassem imunes a qualquer ataque e que todas as matérias fossem conferidas de cima a baixo (p. 125).

No documentário de Laura Poitras, o nome de Barton Gellman não é citado: quem apenas vê o filme sem outras informações a respeito não ficará sabendo dos contatos de Snowden com o jornalista, antes ainda de o Guardian publicar a primeira reportagem a respeito, sobre o acordo do governo com a telefônica Verizon ${ }^{10}$. Não deixa de ser uma forma de apagar sua memória do caso. Gellman entrou na cobertura justamente por intermédio de Poitras, de quem foi colega na Universidade de Nova York (NYU) como conta nos depoimentos.

Diante da dificuldade inicial de contato com Greenwald - que não dera muita atenção à fonte Cincinnatus - , o agente terciarizado da NSA resolveu procurar Poitras, reconhecida por seus documentários críticos em relação à política internacional dos EUA ${ }^{11}$. Os passos da cineasta eram constantemente vigiados pelas autoridades. Snowden pediu sua ajuda para conseguir acesso a Greenwald, o que de fato aconteceu. Mas antes disso - e de viajarem juntos a Hong Kong para encontrá-lo - ela passou o material para Gellman, com quem a fonte começou a se comunicar sob o pseudônimo Verax.

O jornal americano entrou na cobertura do caso no dia 6 de junho, um dia depois do Guardian, com uma reportagem sobre o projeto PRISM, a respeito do acordo do governo dos EUA com empresas como Facebook, Google, Yahoo!, Skype (Microsoft), Apple para ter acesso

\footnotetext{
10 http://www.theguardian.com/world/2013/jun/06/nsa-phone-records-verizon-court-order 
direto aos dados e conteúdos dos usuários ${ }^{12}$. A reportagem, assinada por Gellman e Poitras - embora essa coautoria não seja citada nem por Greenwald nem Harding - foi publicada no site do jornal poucos minutos antes do horário que o Guardian havia estabelecido para pôr online sua segunda reportagem sobre o caso, igualmente a respeito do PRISM. Greenwald escrevia de Hong Kong, com o repórter do Guardian Ewen MacAskill. Harding apenas cita a reportagem do Post, mas Greenwald tece comentários a respeito:

Eu entendi, mas nunca concordei com os motivos que
levaram Laura a envolver o Post. Para mim, a noção de que
precisávamos do envolvimento da Washington oficial era o tipo
de abordagem que eu desejava evitar: um comportamento
excessivamente avesso ao risco, que respeitava as regras
implícitas. Nós éramos tão jornalistas quanto qualquer
profissional do Post, e entregar os documentos a eles para
garantir nossa proteção significava, a meu ver, respaldar as
mesmas premissas que estávamos tentando subverter ( $p$.
134).

O próprio Gellman, nos seus depoimentos, reconhece que Snowden resistia à sua participação por ser ele um profissional da "mídia estabelecida". Há motivos para supor que sem o "furo" do Guardian o Washington Post não teria se envolvido naquele momento. O jornal americano já dispunha de informações a respeito fazia alguns dias e poderia ter publicado antes a reportagem - adiamento que não agradou a Snowden. Além disso, Gellman se recusou a viajar a Hong Kong. Em seus depoimentos, ele chegou a dizer que não iria ajudar Snowden a pedir extradição num território hostil aos EUA, pois isso iria além de sua função de jornalista.

Greenwald, de seu lado, não teria hesitado em proteger a fonte no momento em que ela precisou deixar o hotel apinhado de jornalistas, segundo a versão do documentário. Citizenfour deixa entrever a tensão que envolveu a saída dele do hotel. Inclusive mostra um advogado (ou assessor jurídico) explicando a Snowden, ainda no local, como poderia transcorrer o processo de extradição. $O$ filme também retrata outros

12 http://www.washingtonpost.com/investigations/us-intelligence-mining-data-from-nine-us-internetcompanies-in-broad-secret-program/2013/06/06/3a0c0da8-cebf-11e2-8845-d970ccb04497_story.html 
advogados planejando criar um movimento para apoiá-lo, na medida em que sua ação se respaldaria no interesse público. O documentário seria um exemplo do que se chama em inglês advocacy journalism, em que o profissional, baseando-se em fatos, deixa clara sua perspectiva política e social.

Um dia antes da fuga, o Guardian havia publicado (no domingo, 9 de junho) reportagem revelando a identidade da fonte junto com um filme de 12 minutos editado por Poitras, no qual o jovem se apresentava ${ }^{13}$. Desde o início, ele surpreendeu os jornalistas ao dizer que não iria se esconder - porque não havia feito nada errado, conforme disse, e porque seria inútil, já que o governo o encontraria facilmente. Ele queria assumir sua responsabilidade, tornando-se um modelo para outras pessoas com a intenção de vazar informações, sem repetir erros de antecessores - o caso mais recente era o de Chelsea (Bradley) Manning que passou ao Wikileaks em 2010 milhares de documentos confidenciais do governo americano e foi condenada a 35 anos de prisão. Os documentos tornados públicos em Hong Kong eram ainda mais secretos.

Harding conta que Snowden teria brincado dizendo ser "uma fonte virgem" (2014, p. 189) por nunca ter dado entrevistas - nem no blog de sua namorada ele gostava de mostrar o rosto. Por "virgem", ainda, acrescentamos o sentido de imaculado, uma fonte praticamente perfeita, pois, depois das desconfianças iniciais, os jornalistas chegaram à conclusão de que não era movido por interesses outros além dos que expunha, ou seja, promover o debate público e ficar em paz com sua consciência. Além disso, mostrava-se articulado e psicologicamente equilibrado.

No livro de Harding editado pelo Guardian há três tópicos a destacar no que se refere à afirmação da autoridade jornalística: 1) pela narrativa memorável, o jornal reitera seu compromisso em ter uma 
atuação de vanguarda no novo cenário da mídia digital - a contratação de Greenwald como colunista é relacionada a essa atitude; 2) destacase uma postura mais independente em comparação com a imprensa americana (embora o jornal reconheça que a Primeira Emenda da Constituição americana seja uma importante salvaguarda, por isso optou ao longo da cobertura por fazer um acordo com o New York Times, para divulgarem as informações conjuntamente e protegerem o material das autoridades britânicas ${ }^{14}$ ); 3) valoriza-se a forma de trabalho jornalístico tradicional em detrimento de novas práticas. Sobre o primeiro tópico, vejamos:

Em agosto de 2012, Greenwald deixou o Salon.com e ingressou no Guardian, como colunista freelancer. Foi algo que veio a calhar. Alan Rusbridger, editor do jornal, vê o Guardian ocupando um espaço editorial diferente da maioria dos jornais americanos [...]. Mais do que a maioria dos veículos de mídia, o Guardian abraçou novas tecnologias digitais que mudaram radicalmente a antiga ordem (p. 79)..

Harding afirma que Greenwald "personifica o debate sobre o que significa ser jornalista no século XXI" (p. 87). Mas ele também observa que Greenwald não gosta de ser identificado como integrante do que tem sido chamado de Quinto Estado, o poder que emerge das novas formas de comunicação na internet, como blogs, redes sociais e ferramentas como Wikileaks. Sua resistência a essa ideia, conforme comenta Rusbridger no livro, em parte se deve ao fato de haver uma tendência à falta de proteção jurídica dos profissionais identificados com as novas mídias, que não são vistos como jornalistas genuínos. Inicialmente, no livro, associa-se a independência de Greenwald positivamente face ao sistema da imprensa americana. Mas sua forma de trabalhar foi retratada como oposta à do repórter do Guardian Ewen MacAskill.

MacAskill foi a Hong Kong por imposição do Guardian para se certificarem da idoneidade da fonte - a relação do jornal com

14 Há dois momentos particularmente dramáticos nesse sentido: num deles, agentes do governo britânico vão à redação do Guardian, em Londres, e destroem com martelos o computador onde estariam armazenados os arquivos. Em outro, o brasileiro David Miranda, companheiro de Greenwald, é detido por horas no Aeroporto de Heathrow, sob a acusação de terrorismo. 
Greenwald era recente e ainda não havia plena confiança entre as partes. Sobre este, pode-se ler: "Litigante por profissão, ele passou uma década trabalhando nas cortes federal e estadual. Filho de judeus, truculento, gay, radical e fervoroso quanto à liberdade civil, Greenwald encontrou voz na era Bush" (p. 77). Se pessoalmente é agradável, profissionalmente é uma "criatura diferente": "antagonista, implacável, sarcástico e retórico. É incisivo e impiedoso no que considera hipocrisia oficial americana." (p. 78).

Já o escocês MacAskill, então com 61 anos, repórter político, possuía "experiência e era profissional", conforme destacou Harding. "Era calmo. Era infalivelmente modesto. Todos gostavam dele" (p. 100). O jornalista era um dos profissionais mais respeitados do Guardian: "Em uma carreira altamente considerada, nunca fez nada insidioso $15 "$ (p. 123). Somente no segundo dia em Hong Kong MacAskill conheceu a fonte e teria contribuído com uma apuração profissional:

As perguntas de Greenwald, no dia anterior, haviam sido as de um litigante verbalmente bombardeando uma testemunha duvidosa; o momento de revelação veio quando Snowden falou de quadrinhos e jogos.

MacAskill, em contraste, foi metódico e jornalístico, com seu estilo que complementava o de Greenwald. Ele perguntou a Snowden o básico. Podia mostrar o passaporte, dar o número de seu seguro social e carteira de habilitação? Qual era seu último endereço? Qual era seu salário? (p. 130)

Apesar desse retrato, Greenwald reivindica-se jornalista, tanto quanto qualquer profissional do Washington Post, e ainda mais independente que esses. O fato de Snowden querer jornalistas meticulosos, e ele escolheu Greenwald, explicaria por que o material não foi lançado na internet (como pelo Wikileaks). Se por um lado Greenwald critica padrões que considera viciados na relação da mídia com o poder, por outro, ao afirmar-se jornalista, reitera a importância da atividade a partir de critérios como independência, julgamento editorial e construção de narrativa.

15 Em vez de "insidioso" usada para traduzir "devious", sugerimos "duvidoso", que pode expressar melhor a ideia do original. "Em uma carreira altamente considerada, ele nunca fez nada duvidoso". 
Ele [Snowden] também enfatizou que era vital publicar o material de maneira jornalística, ou seja, trabalhando com a mídia e escrevendo matérias que the proporcionassem contexto, em vez de apenas publicá-lo de uma vez só. Acreditava que essa abordagem fosse proporcionar uma proteção legal maior e, mais importante ainda, permitir ao público processar as revelações de modo muito mais ordenado e racional.

- Se eu quisesse os documentos simplesmente postos na internet todos de uma vez, poderia ter feito isso eu mesmo. Quero que vocês se certifiquem de que essas matérias serão escritas, uma a uma, de forma que as pessoas possam entender o que acontece de fato (GREENWALD, 2014, p. 124-5).

Diante de certa demora do Guardian em pôr no ar a reportagem, Greenwald chegou a aventar a possibilidade de abrir um site com todo o material. Voltou atrás ao ponderar que o peso institucional do jornal seria importante para sua segurança e credibilidade. Essa aliança mesmo que Greenwald seja "uma criatura diferente" - fez com que se integrasse à "comunidade interpretativa" que estabeleceu a visão hegemônica do caso. Os prêmios são o sinal mais evidente.

Se não tivesse sido associado a esses padrões clássicos, e negociado com eles, talvez tivesse sucumbido ao mesmo tipo de tratamento que, na sua visão, a imprensa deu a Julian Assange, o criador do Wikileaks ${ }^{16}$. Greenwald lembra em seu livro que os mesmos jornais que obtiveram prestígio com a divulgação de documentos liberados pelo Wikileaks contribuíram para criar uma imagem negativa de Assange. Por não ser um jornalista tradicional, sem fortes laços com a mídia estabelecida, Greenwald temia ser alvo do mesmo tipo de caracterização negativa. No início, chegou a ser apresentado como blogueiro em vez de jornalista ${ }^{17}$.

Porém, ao contrário do que houve com o Wikileaks, dessa vez

16 O Wikileaks é contraposto negativamente a valores do fazer jornalístico, como no caso em que divulgou o nome de pessoas que poderiam enfrentar riscos com o vazamento de dados sobe ações norte-americanas no Afeganistão e no Iraque, apesar das tentativas dos jornalistas do Guardian de filtrar essas informações (HARDING, 2014, p. 192)

17 O New York Times, embora não único, teria sido particularmente agressivo, mas Greenwald conta que depois os jornalistas envolvidos depois lhe pediram desculpas. 
formou-se uma "comunidade interpretativa" que o incluiu - mesmo com restrições à sua forma de trabalho - e promoveu um processo de reconfiguração. Isso é o que determina o caso como "incidente crítico" para o jornalismo. A ideia de "comunidade interpretativa" se refere ao fato de que, diferentemente de outras categoriais profissionais, os jornalistas não possuem regras rígidas para guiar seu comportamento profissional. A ausência de limites de ação explicitamente definidos sugere um fundo de "autonomia criativa" (ZELIZER, 1992, p. 7).

Há um momento na cobertura possivelmente simbólico desse sentido de "autonomia criativa" que perpassa as instituições. Nos dez dias de intensa cobertura em Hong Kong, os três jornalistas, cada um com um background diferente - Poitras e sua relação controversa com o Washington Post; Greenwald e seu compromisso com a independência; MacAskill com a responsabilidade de profissional respeitado do Guardian - precisaram superar suas diferenças. Longe de seus respectivos ambientes profissionais, criaram um senso comum de urgência e camaradagem ${ }^{18}$ em prol da informação jornalística, precisando improvisar quando necessário para cumprirem a missão diante da qual se viram lançados.

Esse núcleo, embora provisório, estabeleceu os laços a partir dos quais as principais histórias sobre o caso até o momento foram contadas, recriando fronteiras entre práticas profissionais antigas e novas. Destaca-se a instância do fazer profissional, valorizado nos discursos de memória de jornalistas. Ameaçado pela concorrência com o Washington Post, Greenwald pressentiu o que estava em jogo:

Nessa segunda noite em Hong Kong, porém, depois de nos encontrarmos, decidi que não seria o Washington Post, com seu discurso confuso e pró-governo, com seu medo e sua postura em cima do muro, que iria determinar para sempre a forma como a NSA e Snowden seriam compreendidos. Quem quer que desse aquela notícia pela primeira vez iria desempenhar o papel predominante na forma como ela seria debatida e entendida, e eu estava decidido a garantir que fôssemos eu e o Guardian. Para aquilo ter o efeito que deveria ter, as regras implícitas do jornalismo tradicional -

18 Greenwald e Harding descrevem esse ambiente que envolveu os três em Hong Kong. 
criadas para diminuir o impacto das revelações e proteger o governo - precisavam ser quebradas, não obedecidas. O Post as obedeceria; eu, não. (p. 136-7)

\section{Falha da memória: considerações finais}

Em tempos de banalização da informação, o caso Snowden traz novos elementos de consideração sobre as formas contemporâneas de atuação do jornalismo. Huyssen destaca o caráter fragmentário e descartável das memórias na contemporaneidade, a ponto de se perguntar se ainda haveria possibilidade de coesão social. Uma das funções da memória coletiva, compartilhada, seria promover coesão, que, no exemplo estudado, podemos associar à ideia de "comunidade interpretativa".

Por meio de narrativas de memória os jornalistas reconhecemse uns aos outros, privilegiando versões para balizar suas práticas, por sua vez construtoras de tramas de passado. O fato de os jornalistas usufruírem de projeção midiática facilita a circularidade desse processo. Assim se constitui a autoridade interpretativa, e a identidade do grupo.

No que se refere a Snowden, foi possível observar que o jornalismo dito tradicional precisou ampliar fronteiras de autodefinição para abarcar parâmetros de práticas do chamado advocacy journalism em voga nas mídias digitais, embora isso não tenha se dado sem resistência e desconfiança. Houve uma troca de credibilidade: a mídia estabelecida tomou algo emprestado da imagem de independência do profissional do digital, que, de seu lado, contou com o aparato institucional para ser menos vulnerável e ampliar a força das suas denúncias.

Mais do que o ideal do repórter investigativo, os valores da opinião relacionados ao advocacy journalism foram preponderantes no caso Snowden: deixar claro de que lugar se falava, com base nos fatos mostrados, mostrou-se fundamental. Assim, entre os valores jornalísticos da comunidade interpretativa nesse caso, sobressaemse independência, julgamento editorial, construção de narrativa e de contextos de leitura. 
Na perspectiva de Huyssen, entretanto, diante da fragmentação relacionada à aceleração temporal, deve-se observar o valor potencialmente efêmero, precário, dessa comunidade interpretativa. 0 jogo da memória com a mídia na contemporaneidade é marcado pela instabilidade, em processos contínuos de reconfiguração.

O modelo snowdiano mostra que, em última instância, diante da vigília permanente - com aparatos de espionagem funcionando sem cessar, cada vez mais potentes -, desloca-se o sentido do esquecimento diante do arquivamento. Tudo pode ser potencialmente recuperado. Em última instância, não há mais por que temer o esquecimento: as falhas da memória tornam-se acidentes de percurso. A hipertrofia da memória, temida por Huyssen, ganha também um sentido de subversão hacker. Em vez de temido, o esquecimento passa a ser até desejado, e mesmo reivindicado como direito.

Outro aspecto a ser levado em conta, a partir de Huyssen em sua releitura de Nora, é o de lugares de memória que funcionam "não apenas como um campo expandido mas como um campo alterado pela globalização" (p. 97). Se Huyssen se preocupa com a interação da dimensão global com a local - buscando superar a ideia de memória nacional cara a Nora - o caso Snowden evidencia e aprofunda o design desse trajeto: parte do global para o local e, mais ainda, para o individual, e vice-versa. Esse também seria trajeto do jornalismo: a partir do individual, atuando em nível local ou nacional, cada vez menos se pode abrir mão da negociação com o global ${ }^{19}$.

Essas dimensões evidenciam reconfigurações do jornalismo como repositório de memória nas sociedades onde ele se faz presente historicamente, no sentido proposto por Zelizer. Na Modernidade, segundo ela, o jornalismo prevaleceu onde a memória falhou. A memória era tida como incerta e fluida, enquanto o jornalismo era associado à objetividade, à imparcialidade, ao equilíbrio e à razão. Hoje,

19 O próprio caso Snowden é sintomático das formas de trabalho na globalização. A reportagem envolveu lugares como Rio de Janeiro, Hawai (de onde Snowden começou a se comunicar com as fontes), Nova York, Washington, Londres, Berlim (onde Poitras se baseava) e Hong Kong - além de Moscou, onde Snowden obteve asilo político quando estava a caminho do Equador. 
porém, a memória deixa de ser fluida para se tornar técnica, precisa, armazenada em arquivos totais, enquanto o jornalismo, de seu lado, cede à opinião, à instabilidade, à entropia, deixa de ser reconhecível com base em parâmetros fixos. Os termos trocam de significado em relação à maneira como foram classicamente definidos na Modernidade.

Se a memória não é mais a mesma, a "falha da memória" adquire novo significado. Não há falha por esquecimento, mas por problemas técnicos ou erro humano (voluntário ou involuntário). Ao estudar a natureza dos arquivos digitais, Colombo já detectava, há 30 anos, sua natureza imperfeita: apesar da sua promessa de totalidade, os arquivos são inevitavelmente imperfeitos, e a memória técnica revela-se no fim um espelho de enganos. Em que medida, hoje, a falha da memória seria a brecha para a atuação do jornalismo? Snowden representa a falha no sistema. Com ele, novamente se pode dizer, embora com as definições dos termos invertidas: lá onde a memória falhou, o jornalismo prevaleceu.

\section{Referências bibliográficas}

COLOMBO, Fausto. Os arquivos imperfeitos: memória social e cultura eletrônica. Tradução do italiano de Beatriz Borges. - São Paulo: Editora Perspectiva, 1991 [1986].

GREENWALD, Glenn. Sem lugar para se esconder. Tradução do inglês de Fernanda Abreu. Rio de Janeiro, Sextante: 2014.

HUYSSEN, Andrea. Present pasts: Urban palimpsests and the politics of memory. - Stanford, Califórnia: Stanford University Press, 2003.

HALBWACHS, Maurice. A memória coletiva. - São Paulo: Vértice, 1990.

HARDING, Luke. The Snowden Files: The inside story of the world's most wanted man. - Londres: Guardian Books, 2014.

HARDING, Luke. Os arquivos Snowden: a história secreta do homem mais procurado do mundo. Tradução de Alice Klesck e Bruno Correia. Rio de Janeiro: LeYa, 2014.

MCGREGOR, Susan. Digital security and source protection for journalists. Tow Center for Digital Journalism A Tow/ Knight Report. Columbia Journalism Center, 2015.

NORA, Pierre. Les lieux de mémoire. Paris: Gallimard, 1984. 
RIBEIRO, Ana Paula Goulart; FREIRE FILHO, João; HERSCHMANN, Micael. Entretenimento, felicidade e memória: forças moventes do contemporâneo. Guararema, SP: Anadarco, 2012.

RIBEIRO, Ana Paula Goulart; FERREIRA, Lúcia (orgs.). Mídia e memória. Rio de Janeiro, Mauad X, 2007.

ZELIZER, Barbie. Covering the body: The Kennedy Assassination, the Media, and the Shaping of Collective Memory. Chicago: The University of Chicago Press, 1992.

TENENBOIM-WEINBLATT, Keren (orgs.). Journalism and memory [ebook]. Nova York: Palgrave Macmillan, 2014.

ALLAN, Stuart (orgs.). Journalism after 11 September.

- Londres e Nova York: Routledge, 2011, segunda edição [2002].

CALDEIRA, Clara. Resenção: Journalism and memory, de ZELIZER, Barbie e TENENBOIM-WEINBLATT, Keren (orgs.), in Diffractions: Vol 3, 2014.

Depoimentos selecionados de Barton Gellman:

http://www.pbs.org/wgbh/pages/frontline/government-elections-politics/unitedstates-of-secrets/the-frontline-interview-barton-gellman/

http://www.npr.org/2013/09/11/221359323/reporter-had-to-decide-if-snowdenleaks-were-the-real-thing; https://www.youtube.com/watch?v=RzjDraZxLCE

https://www.youtube.com/watch?v=ItHsA8R0JsY 


\section{A PLATAFORMA @BRNASRUAS E A FORMAÇÃO DE MEMÓRIA COLETIVA SOBRE OS PROTESTOS DE JUNHO DE 2013 NO BRASIL}

\section{THE @BRNASRUAS PLATFORM AND THE FORMATION OF COLLECTIVE MEMORY ABOUT JUNE PROTESTS IN
BRAZIL} Edição v.35 número 3 / 2016-17

Contracampo e-ISSN 2238-2577 Niterói (RJ), v. 35, n. 3

dez/2016-mar/2017

A Revista Contracampo é uma revista eletrônica do Programa de Pós-Graduação em Comunicação da Universidade Federal Fluminense e tem como objetivo contribuir para a reflexão crítica em torno do campo midiático, atuando como espaço de circulação da pesquisa e do pensamento acadêmico.

\section{MARIA CLARA AQQUINO BITTENCOURT}

Professora e pesquisadora do Programa de Pós-Graduação em Ciências da Comunicação da Universidade do Vale do Rio dos Sinos. Pós-Doutora em Ciências da Comunicação pelo mesmo programa. Doutora e mestre em Comunicação e Informação pelo Programa de Pós-Graduação em Comunicação e Informação da Universidade Federal do Rio Grande do Sul. Graduada em Comunicação Social, habilitação Jornalismo, pela Universidade Católica de Pelotas. Brasil.

\section{PPG|COM}

AO CITAR ESTE ARTIGO, UTILIZE A SEGUINTE REFERÊNCIA:

BITTENCOURT, Maria Clara Aquino. A Plataforma @BRnasruas e a Formação de Memória Coletiva sobre os Protestos de Junho de 2013 no Brasil. Contracampo, Niterói, v.35, n. 03, dez. 2016/ mar. 2017. 


\section{Resumo}

Este artigo observa a plataforma @BRnasRuas, agregadora de conteúdo sobre os protestos que aconteceram em junho no Brasil. O objetivo é identificar como a plataforma registra e recupera conteúdos espalhados na rede através de hashtags e como tais processos estão relacionados com a formação de memória. A observação da plataforma e uma entrevista com um de seus criadores auxiliou no entendimento sobre o funcionamento do site e na avaliação dos mecanismos de filtragem e colaboração para entender o impacto da produção colaborativa na formação e na manutenção de uma memória coletiva sobre os protestos no país.

\section{Palavras-chave}

memória coletiva; @BRnasruas; hashtags

\section{Abstract}

This paper notes the platform @BRnasRuas, which is an aggregator of content about the protests that happened in June in Brazil. The objective is to identify how the platform records and retrieves contents scattered on the network through hashtags and how these processes are related to memory formation. The observation of the platform and an interview with one of its creators has aided the understanding of the functioning of the site and evaluation of filtering and collaboration to understand the impact of collaborative production in formation and maintenance of a collective memory about the protests in the country. The case study in question contributes to the understanding of changes in the field of journalism from the use of digital communication technologies.

\section{Keywords}

collective hashtags memory; @BRnasruas; 


\section{Introdução}

A incorporação de ferramentas de comunicação no cotidiano de movimentos sociais, que ocorre há muito antes da criação e desenvolvimento da Internet e da $w e b$, vê hoje na conexão sem fio e no uso de dispositivos móveis a ampliação de oportunidades midiáticas antes limitadas. Gohn (2010) relata que essa apropriação fortalece possibilidades de articulação e estratégias de visibilidade aos movimentos, reconfigurando formas de organização e ação. Para Castells (2012), esse suporte técnico ampara a constituição de uma forma de manifestação mais horizontal e menos centralizada, através da qual, fluxos alternativos de informação recebem tanta atenção quanto os da mídia tradicional. De fato, a ocorrência de levantes populares nos últimos anos, como o movimento de Seattle (1999) e as manifestações da Primavera Árabe (2011), torna ainda mais latente a reflexão sobre as práticas comunicacionais orientadas pelo engajamento coletivo na construção e no uso de ferramentas digitais de comunicação para reportar os fatos e divulgar causas de movimentos diversos.

O aproveitamento das possibilidades digitais na narrativa das ruas revela um fluxo de informação paralelo ao estabelecido pela mídia de massa. Retomando a teoria dos campos de Bourdieu (1983), é preciso reconsiderar a composição do campo midiático como representante legítimo de outros campos da sociedade. Este campo já não é mais formado unicamente pela mídia de massa. A apropriação da internet, web e demais ferramentas digitais de comunicação por movimentos, ativistas e cidadãos reflete a inserção de novos atores no campo midiático, os quais interferem no fluxo informacional. A produção e a circulação de conteúdo através das redes retira da mídia de massa o monopólio da narrativa sobre os protestos (MALINI E ANTOUN, 2013) e assim amplia espaços pelos quais a informação fica registrada e pode ser recuperada.

Este artigo observa a plataforma @BRnasRuas ${ }^{1}$, agregadora 
de conteúdos sobre os protestos no Brasil e publicados por contas no Facebook, Twitter, blogs e sites independentes. O mapeamento da informação é feito através de hashtags e filtros que buscam os conteúdos. Entende-se que esse tipo de plataforma faz parte de um fluxo informacional sobre os protestos paralelo ao fluxo da mídia de massa. Assim, o objetivo é identificar como se dá o registro e a recuperação de conteúdos através de hashtags de conteúdos espalhados pela rede e como tais processos estão relacionados com a formação de memória. A observação do funcionamento da plataforma e a interpretação das respostas a uma entrevista com um de seus criadores auxiliaram no entendimento sobre o funcionamento do site e na avaliação dos mecanismos de filtragem e colaboração para entender o impacto da produção colaborativa na formação e na manutenção de uma memória coletiva sobre os protestos no país. O estudo do caso em questão contribui para uma pesquisa que investiga transformações no campo do jornalismo digital a partir de apropriações de tecnologias digitais de comunicação por grupos independentes que visam produzir conteúdo acerca de movimentos sociais e mobilizações em rede.

\section{Recuperação de informação no contexto digital e memória coletiva}

Nos anos 90, Lévy (1996) dizia que a partir do hipertexto da web toda a leitura havia transformado-se em ato de escrita, em função das possibilidades de se criar e modificar links entre documentos. No entanto, a verdade é que o hipertexto do início da web limitava a atividade dos que não sabiam programar a navegação não linear pelas páginas. A disposição dos links e a inserção de conteúdo eram privilégios de poucos, ainda que logo a liberdade de emissão de conteúdo viesse a crescer de forma significativa a partir do desenvolvimento de ferramentas de fácil manuseio, como os blogs, por exemplo. Com o aumento da quantidade de informação na rede ampliou-se ainda mais a discussão em torno da recuperação dos dados e da constituição de 
memória em torno dos acontecimentos.

No campo do jornalismo, Christofoletti e Laux (2008) lembram como a disseminação dos blogs desencadeou transformações em processos de apuração e difusão de informações, ao mesmo tempo em que provocou novas formas de relacionamento entre produtores e consumidores de informação. Os autores apontam diferentes usos dos blogs por parte de veículos jornalísticos, mostrando a pouca influência das páginas nas rotinas da imprensa. Mas a verdade é que os blogs ganharam a web antes de conquistarem o jornalismo. Recuero (2003) lembra a identificação inicial dos blogs como "tendência de diarismo na internet", para só posteriormente representar uma quebra de paradigmas no jornalismo. Ela considera que a Guerra do Iraque tornou clara a influência dos blogs no jornalismo com a proliferação dos warblogs - blogs que narravam os fatos da guerra e eram escritos tanto por pessoas sem formação jornalística quanto por jornalistas da imprensa oficial. ${ }^{2}$ Com a legitimação dos blogs como ferramenta jornalística nascem novas oportunidades de mídia para um fluxo informacional paralelo aos meios de massa.

No início dos anos 2000, Dreyfus (2001) apontava a geração dos links por qualquer indivíduo, conectando um documento a outro, como uma dificuldade de se encontrar informação online. Com a popularização da web, apropriações diversas surgiram para facilitar a recuperação de conteúdo. A colaboração já fazia parte de muitas dessas ferramentas ${ }^{3}$ e a folksonomia ${ }^{4}$ foi uma dessas apropriações que acabou incorporada pelos blogs, jornalísticos ou não, e também por sites e portais noticiosos. As tags (etiquetas) ao final dos posts e textos jornalísticos possibilitaram o mapeamento hipertextual de temas pela rede, facilitando a busca e a recuperação de conteúdos sobre qualquer assunto. Vander Wall (2006), criador do termo folksonomia, explica que "o valor desse etiquetamento externo deriva das pessoas usando

2 Recuero (2003) diz que na época foi criada a Warblogs.cc, plataforma agregadora de blogs de guerra. 3 A rede de fotografias Flickr (http://flickr.com) foi um dos primeiros sites a utilizar as tags para catalogar as imagens.

4 Termo utilizado para definir a prática de organização de arquivos através do uso de tags (etiquetas). 
seu próprio vocabulário e adicionando significado explícito, o que pode vir de um entendimento inferido daquela informação ou objeto" ${ }^{\prime 5}{ }^{6}$

No caso das redes sociais, o Twitter é o exemplo mais forte do uso das hashtags de forma colaborativa na organização e recuperação dos tweets publicados. Para a comunicação de movimentos sociais e coletivos no âmbito de mobilizações sociais em rede, a prática tem sido fundamental na organização de atos e protestos e para o registro e a recuperação dos conteúdos publicados sobre os acontecimentos. 0 mapeamento das hashtags no Twitter tem servido para a investigação científica sobre os movimentos ao redor do mundo, como se pode observar nos estudos de Toret (2012), Recuero (2014) e Bastos, Recuero e Zago (2014). Assim, a possibilidade de qualquer indivíduo etiquetar conteúdo online altera os padrões hipertextuais da rede, já que a colaboração em torno da criação das hashtags permite a organização semântica das informações, ampliando caminhos de busca por informação online. Diante da constituição de um fluxo informacional paralelo ao estabelecido pela mídia de massa, as hashtags são fundamentais para o mapeamento desse conteúdo. Recuperar informações espalhadas pela rede sob inúmeros perfis em redes sociais, sites e blogs independentes é tarefa facilitada através das hashtags e de ferramentas que reúnem conteúdo a partir do mapeamento dessa prática coletiva.

\section{As narrativas dos protestos nas redes}

Observar as formas pelas quais atores diversos vêm construindo e espalhando histórias e informações através das redes é um caminho para identificar como o jornalismo pode e precisa ser reconfigurado diante da pluralidade de usos e apropriações comunicacionais. Nunes (2014), entre outros autores, trabalha com a ideia de sistema-rede para pensar os protestos que vêm ocorrendo não só no Brasil, mas em

\footnotetext{
5 Aquino (2007) aborda a folksonomia como um novo tipo de hipertexto na segunda fase da web. Disponível em: http://goo.gl/WTfhp1

6 "The value in this external tagging is derived from people using their own vocabulary and adding explicit meaning, which may come from inferred understanding of the information/object"
} 
outros países.

O sistema-rede é um sistema com diversas camadas, cada uma das quais é uma rede: a rede de pessoas na rua, de perfis do Facebook, de contas do Twitter, de espaços físicos em que as pessoas se encontram. As camadas não são redutíveis uma a outra. Nem todo mundo está em todas, e a rede no Twitter é diferente daquela do Facebook, que é diferente daquela do mundo físico. Os laços são outros, os nós são outros. Mas elas pertencem todas ao mesmo sistema, ou seja, interagem todo o tempo.

Essa estrutura em camadas também é abordada por Toret (2012) em sua análise sobre o movimento espanhol \#15M. Ele explica que a circulação de informação pela internet através de redes sociais, coletivos de notícias, blogs e até pelos meios estrangeiros ao mesmo tempo em que rompeu o monopólio de agendamento feito pela mídia de massa, obrigou a mesma a noticiar o que acontecia nas ruas. 0 que aconteceu foi a geração de um sistema rede composto por formas organizativas distribuídas pelas camadas física e digital, responsáveis por ampliar e dar sentido ao sistema através de uma narrativa coletiva transmidiática.

É fato que, não apenas na Espanha, as informações sobre os protestos partem de múltiplas origens: mídia de massa, mídia independente, cidadãos e movimentos têm acesso a dispositivos e espaços de publicação de conteúdo. Esse ambiente é cada vez mais mediatizado pela comunicação de massa e pela autocomunicação de massa, explica Nunes (2014). O filósofo lembra que na época das Diretas, com o país ainda sob o controle da ditadura e com a mídia bloqueada, era necessário o aporte de organizações estruturadas nacionalmente e lideranças que se deslocassem pelo país. Hoje, ele chama a atenção sobre como se fortalece, cada vez mais, um fluxo contínuo de informação que trafega por diferentes meios, e destaca oportunidades de participação desse fluxo através da emissão de opiniões, propostas e sentimentos. Malini e Antoun (2013, p. 157) se debruçam sobre esses processos de "narração coletiva dos acontecimentos públicos", e os entendem como o laboratório das disputas entre a velha e a nova mídia, entre o governo e as corporações e os movimentos, ativistas 
e cidadãos. Disso, entendem que devem resultar "novas narrativas multitudinárias", que vão passar de um "modelo informacional baseado na "acumulação quantitativa prioritária de produtos, para o modelo comunicacional das multimídias, que privilegia a coordenação da ação coletiva dos movimentos."

A adoção de ferramentas de comunicação digital tem sido central na condução de narrativas ao vivo sobre atos e manifestações de rua. Zago (2011) comenta que o uso dessas ferramentas por indivíduos sem formação jornalística se traduz tanto como fator de colaboração para a produção de notícias em veículos tradicionais, como para publicação em espaços autônomos. O aproveitamento da velocidade de publicação no Twitter aparece nas coberturas dos mais diversos eventos, e não vem sendo diferente nos protestos ao redor do mundo como, por exemplo, nos casos do Occupy Wall Street, nos Estados Unidos, e Indignados, na Espanha, em 2010 e Primavera Árabe, no Oriente Médio, em 2011.

A apropriação dessas mídias sociais vai além do Twitter e do Facebook, explorando outras plataformas para potencializar a comunicação no âmbito dos protestos e mobilizações de rua, mas são as contas nas redes sociais e os sites e blogs que concentram as informações sobre o que se passa nas ruas. Lotan et al. (2011) analisaram o uso do Twitter nas revoluções no Egito e na Tunísia e verificaram que ainda que mais jornalistas do que blogueiros tenham atuado como fontes de informação, blogueiros e ativistas obtiveram mais alcance na divulgação de informações sobre os acontecimentos nas ruas. Para os autores, os meios de massa adotam o Twitter para ampliar o público e o envolvimento com o mesmo, o que acaba por alterar a forma como dependem de outras fontes e as republicam.

Malini (2013) enxerga um movimento feito por alguns veículos de imprensa para capturar as narrativas das redes sociais para a narrativa jornalística e a partir dessa percepção aborda a relação entre autoridade e centralidade quando a imprensa também atua nas redes sociais. Em 
julho de 2013 a Folha de São Paulo publicou matéria7 afirmando que o conteúdo produzido sobre os protestos de junho por jornais, portais e canais de televisão brasileiros havia dominado o compartilhamento nas redes sociais. Malini (2013) explica que o jornalismo da imprensa formada por grandes e até pequenas empresas alcança altos níveis de compartilhamento pelo fato dessas empresas terem acesso rápido ao poder constituído e a determinados setores da sociedade civil, além de concentrarem recursos financeiros que possibilitam a proximidade e o controle das fontes. A distribuição de informação pela imprensa nas redes sociais gera o compartilhamento, ocasionando a autoridade de perfis noticiosos. No entanto, perfis oficiais de mobilização também podem ter conteúdos compartilhados em grande escala, pois detêm informações exclusivas sobre fatos e estratégias. O autor alerta para o fato de que autoridade não é a mesma coisa que centralidade, que os ativistas detêm. Enquanto perfis da imprensa concentram o uso das redes sociais sob um modelo de distribuição de conteúdos e informações para milhares de seguidores, a densidade das relações é maior e os níveis de interação são mais intensos entre os ativistas, que dialogam, compartilham e republicam uns aos outros através das redes sociais. Assim, Malini (2013) diz que "a centralidade mensura a capacidade de um "nó" (um perfil nas redes sociais) de ser capaz de atrair conexões, distribuir conexões, ser ponte para outras pessoas, articular mundos". Conforme o autor, não adianta um perfil de um veículo de imprensa possuir autoridade e ao mesmo tempo estar isolado dos indivíduos que interagem intensamente em torno de outros perfis.

Enquanto a mídia de massa parece ainda seguir um modelo de comunicação baseado na unilateralidade da produção e na distribuição de conteúdo, a comunicação sobre os acontecimentos nas ruas por movimentos, coletivos e cidadãos é baseada na produção e distribuição coletivas. Enquanto um veículo jornalístico concentra matérias e reportagens em arquivos recuperáveis através de links e hastags

7 Disponível em: $\underline{\text { http://goo.gl/12edx0 }}$ 
internas aos sites e portais, a produção colaborativa dos movimentos se espalha pela rede em diversos espaços online, representados por perfis em redes sociais, hoje principalmente pelo Twitter e Facebook. Toret (2012) defenda o uso do Twitter no contexto das mobilizações - por ser mais aberto que o Facebook -, mas é importante destacar aqui que a ferramenta apresenta dificuldades na recuperação de conteúdo mais antigo. No Twitter, sem contar com outros mecanismos de recuperação de tweets $^{8}$, não é possível recuperar todos os tweets de uma conta. Em ferramentas como Facebook, as publicações não desaparecem com o tempo, podendo ser recuperadas; ainda que a busca deste site de rede social não ofereça mecanismos para pesquisa avançada, fazendo que a procura seja mais demorada, em alguns casos.

Dessa forma, toda a atividade colaborativa em torno de perfis, sites e blogs que publicam sobre protestos e mobilizações de rua, independente da produção de conteúdo distribuída pela mídia de massa, interfere na maneira como as informações são armazenadas e recuperadas posteriormente. Para entender como esse fluxo de informações paralelo à mídia de massa vem atuando na mediação da memória coletiva sobre os protestos de junho de 2013 no Brasil, o próximo item recupera algumas considerações sobre memória.

\section{Memória coletiva}

Construir uma lembrança é vasculhar uma rede de associações na memória, e o mesmo se faz online, através do hipertexto. Para Halbwachs (2004), para pensar a evocação de lembranças é preciso considerar os quadros sociais que servem de referência para a memória. As lembranças dependem desses quadros de referência no qual indivíduos e grupos evoluem. Ele lembra que os seres humanos são sociais, pois sempre contam com a participação de memórias alheias. Essa formação de impressões com base não só na própria memória confere maior confiança na exatidão daquilo que buscam.

8 Mecanismos como o Topsy (http://topsy.com/) auxiliam na recuperação de tweets. 
Gondar (2006) entende a memória como algo construído através de relações sociais, algo que vai além da verdade pura e simples de um ocorrido. Na mesma linha, Sepúlveda (2003, p. 25) afirma que "a memória está presente em tudo e em todos", refletindo a ideia de conexão entre indivíduos e meios que influenciam na construção da memória. A autora apoia-se em Halbwachs para argumentar que a memória é sempre coletiva.

Tais argumentações não abordam o contexto online e a constituição da memória coletiva a partir de usos e apropriações de dispositivos digitais, mas podem ser apropriadas para uma reflexão nesse sentido. A formação da memória dos protestos de junho de 2013, além dos conteúdos veiculados pela mídia tradicional, pode ser amparada na atividade de perfis de redes sociais, sites e blogs independentes que relatam os acontecimentos e mapeiam as informações através de práticas coletivas de produção e circulação de conteúdos. Casalegno (2006, p. 21) entende que a memória coletiva ocorre "quando toda a coletividade pode acessá-la e nutri-la, porque são os indivíduos que participam de sua criação, e não as instituições oficiais". Pautados pela construção de meios e formatos mais democráticos que os instituídos pela mídia de massa, movimentos e coletivos sociais apropriam-se de ferramentas que permitem, além do acesso público, a inserção de conteúdo de forma colaborativa. ${ }^{9}$

Padrões de rede vêm guiando a narrativa independente sobre os acontecimentos nas ruas. Gutierrez (2013) aponta memes, estética, processos e protocolos compartilhados na configuração dos movimentos em rede. O mesmo se aplica aos que trabalham conteúdos sobre os protestos com base na lógica das redes e na exploração de formatos de visualização em conjunto com táticas de ocupação do espaço público como forma de cobertura e ativismo. A ocupação do espaço público transcende as ruas através da conexão e assim identidades coletivas reverberam os conteúdos colaborativos sobre os acontecimentos pelas

9 Em resposta à entrevista, Gutierrez, um dos criadores do @BRnasruas, afirma que o trabalho desenvolvido na plataforma busca se diferenciar do modelo de comunicação da mídia de massa. 
redes, colocando em discussão além das causas, o poder da mídia de massa sobre a narração dos acontecimentos. Nesse cenário, a formação da memória sobre os protestos, que já não dependia unicamente da mídia de massa antes do surgimento da internet e de tecnologias digitais de comunicação, é potencializada em diferentes espaços online. A produção de conteúdo descolada da imprensa tradicional e impulsionada pela circulação nas redes vem cada vez mais fortalecendo seu papel no imaginário coletivo sobre os protestos, contribuindo para o estabelecimento de um fluxo informacional paralelo e guiado pela lógica das redes.

Focado nas tecnologias digitais e na relação entre memória, comunidade e redes, Rösnay (2006) acredita na configuração de memória implícita e memória explícita. A explícita é composta pelas informações armazenadas em bases de dados, podendo ser recuperada por mecanismos de busca. A implícita é autoconstruída como um link na web, que quando criado constitui-se em uma via de acesso, um link implícito de memória. Pelo fato de permitirem a intercomunicabilidade na web, o autor considera que os links, aliados a interação e intercriação, favorecem a memória coletiva na rede. Logo, é através da liberdade de intervenção na construção do hipertexto, das conexões que o formam e do contínuo enriquecimento e gerenciamento dessas conexões que os indivíduos constroem e acessam uma memória coletiva e dinâmica, que está sempre em movimento e aperfeiçoamento a partir da colaboração.

O próximo item apresenta a plataforma @BRnasruas.

\section{5. @BRnasruas}

A ideia de criar o @BRnasruas nasceu no final de junho de 2013, em uma lista de e-mails que reunia pessoas e coletivos atuantes nos protestos que aconteciam naquela época no Brasil. O site foi lançado em fevereiro de 2014. Bernardo Gutierrez, um dos criadores da plataforma, em entrevista para este estudo, explica que inicialmente a lista agregou assembleias, movimentos de ocupação e pessoas 


\section{Contracampo}

especialmente ativas nos protestos. Em seguida surgiram os perfis no Facebook e Twitter. Ele diz que o objetivo principal não era a quantidade de informações nos perfis, mas o estabelecimento de relações através do compartilhamento e da conexão entre pessoas e informações. Cerca de 300 pessoas formaram, através dos diálogos sobre os protestos, segundo Gutierrez, um "ecossistema" que acabou gerando o desenvolvimento da plataforma. Gutierrez descreve o site como "um semi agregador ao serviço do bem comum". O principal trabalho é de curadoria, de escolha de fontes - sempre independentes - e da inserção de filtros que eliminam ruído, como spam e outras mensagens. O funcionamento se dá pelo recolhimento de contas no Twitter, através de uma lista própria da conta do @BRnasruas, fanpages no Facebook e RSS de blogs. Algumas hashtags também são escolhidas como forma de garimpar a informação. Além da página inicial, outras seis seções reúnem conteúdo sobre os protestos: \#ACidadeÉNossa; \#OcupaCopa; ProtestosBR; Vandalismo Policial; Passe Livre e \#OcupeAMídia.

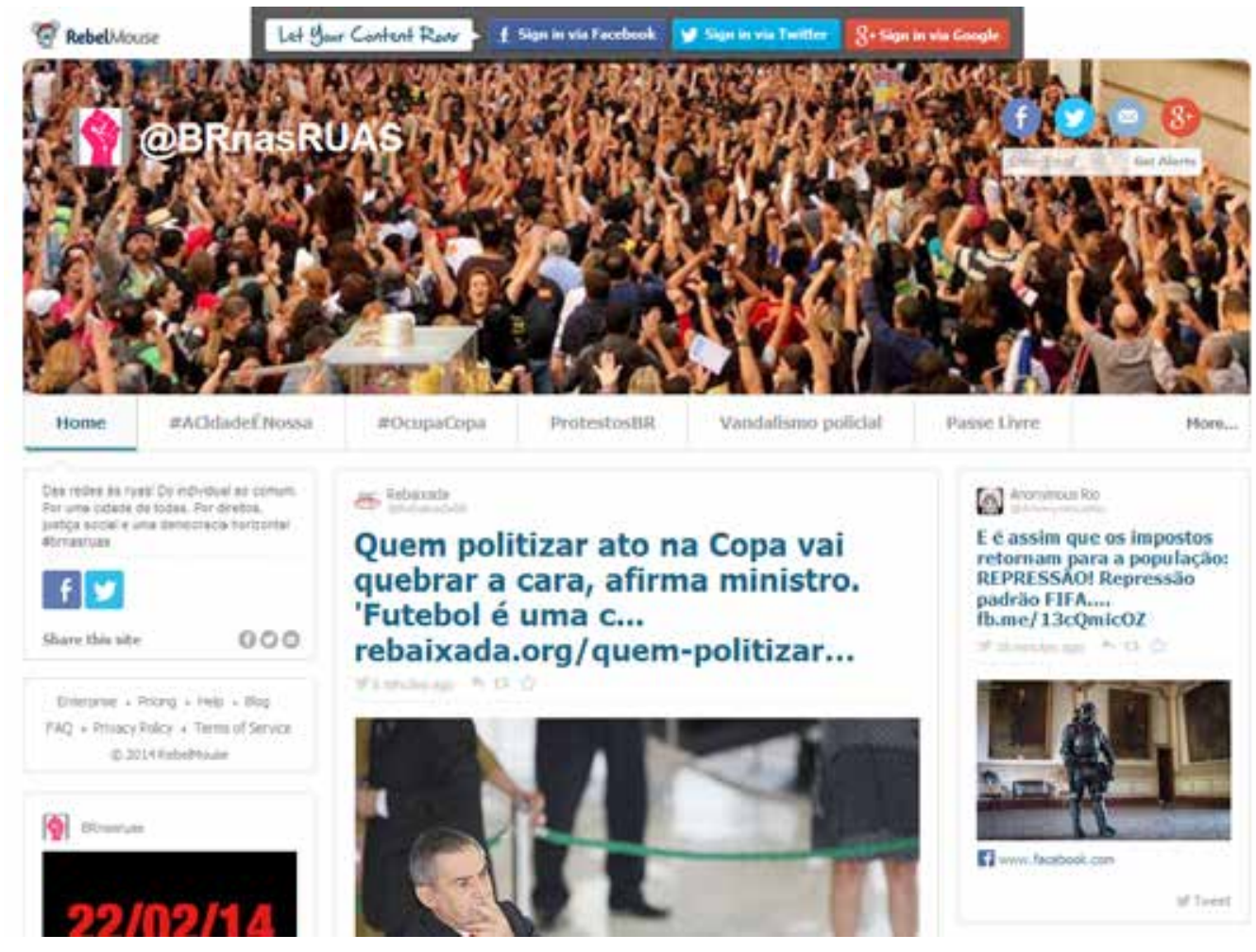

Plataforma @BRnasruas - http://brnasruas.com 
Por ser uma plataforma semi automatizada, a publicação é feita a partir da seleção das contas de redes sociais e blogs. Este filtro é feito pelos administradores da conta do @BRnasruas no Facebook e alguns editores, de forma que não há como especificar quantas pessoas contribuem com o conteúdo disponibilizado na plataforma cada conta selecionada pode ser editada por uma ou mais pessoas. Após a definição de uma hashtag, os conteúdos entram numa fila de rascunhos e precisam ser aprovados por algum dos editores. Se um conteúdo aparece no site e não é "considerado apropriado", nas palavras de Gutierrez, é removido. Ele explica que a filtragem é semi automática, pois precisa ser complementada pela curadoria humana: "@BRnasRuas poderia ser definido como jornalismo ciborg, pessoas e máquinas, algoritmos e sensibilidade humana". Logo, o conteúdo do @ BRnasruas é produto de contas em redes sociais e blogs previamente escolhidos para que suas publicações apareçam no site, através de compilação na lista 'Contas Coletivas'10 no Twitter, e de contas no Facebook. Há conteúdo próprio, inserido pelos editores, mas não existe um mecanismo ou seção através do qual um indivíduo possa enviar conteúdo para que seja publicado no site.

A plataforma de base do @BRnasruas é a RebelMouse. ${ }^{11}$ Gutierrez explica que por ser muito complexa, algumas funções e o código vêm sendo modificados. As hashtags são importantes para a seleção dos conteúdos, mas ele destaca que a matriz do @BRnasruas é a curadoria coletiva ao longo dos meses posteriores aos protestos de junho.

Conteúdos sem link de acesso são deixados de fora, pela impossibilidade de se filtrar o volume de informações, mas não há preferência por formato (textos, fotos, vídeos, áudios ou links). O ideal é que o conteúdo seja independente. Conteúdo da mídia de massa só aparece quando alguma das contas selecionadas compartilha, mas Gutierrez diz que é raro acontecer, "já que a grande mídia brasileira

\footnotetext{
10 https://twitter.com/BRnasRuas/contascoletivas/

11 https://www.rebelmouse.com/ Plataforma que potencializa a publicação de conteúdo independente valorizando a instantaneidade das publicações.
} 
é muito ruim e manipula muito os protestos". Quando questionado sobre o modelo do @BRnasruas, ele diz que o site busca se diferenciar totalmente da mídia de massa em seu modelo de comunicação, atuando como "um filtro na era da abundância" e enfatiza o caráter não comercial do site, pontuando que nunca aceitará publicidade.

O @BRnasruas promove a circulação dos conteúdos agregados via replicação no Twitter e Facebook. Gutierrez aponta que como cada post gera uma url distinta, o SEO ${ }^{12}$ do Google auxilia nessa replicação. No entanto, a plataforma ainda não oferece uma forma definida para a recuperação do conteúdo agregado. Junto com cada conteúdo ficam visíveis botões de compartilhamento no Twitter e no Facebook, além da opção de se favoritar o conteúdo para uma leitura posterior. Qualquer indivíduo pode se cadastrar na plataforma e armazenar o conteúdo para leitura. Também é possível assinar a newsletter do @BRnasruas para receber uma compilação de conteúdos.

\section{Metodologia e análise}

Como metodologia optou-se pelas técnicas de observação e entrevista, com base em Fragoso, Recuero e Amaral (2011) e Duarte e Barros (2008). A observação buscou identificar a estrutura básica de funcionamento da plataforma para identificar o papel das hashtags na constituição da memória. Em função da ausência de informações sobre os critérios de filtragem de conteúdos, considerou-se relevante realizar uma entrevista, que foi feita por e-mail, ${ }^{13}$ com Bernardo Gutierrez, um dos criadores do site.

Inicialmente, é preciso considerar que a criação de uma plataforma agregadora de conteúdo sobre os protestos só é possível a partir das possibilidades de articulação e de estratégias de visibilidade trazidas pela adoção de tecnologias de comunicação no contexto dos movimentos sociais, como aponta Gohn (2010). Sua construção e

\footnotetext{
12 SEO - Search Engine Optimization - processo que afeta a visibilidade de um site dentro de um buscador.

13 As perguntas podem ser visualizadas em: http://goo.gl/kcZHFD
} 
manutenção fazem parte do fluxo alternativo de informação (CASTELLS, 2012). Primeiro pelo fato de agregar apenas conteúdo independente, e depois por práticas como a reunião de contas de identidades coletivas, como menciona Gutierrez ao se referir às contas selecionadas, assim potencialmente retirando o monopólio de narração da mídia de massa (MALINI E ANTOUN, 2013), ao auxiliar na expansão da visibilidade dos conteúdos espalhados pela rede. Porém, não há como ignorar o fato de que a plataforma, por ser agregadora, tem potencial colaborativo limitado, já que existe uma seleção prévia do conteúdo que será agregado.

Ao explicar a motivação do @BRnasruas, Gutierrez menciona a formação de "um novo sujeito político-social", que surgiu nas jornadas de junho. Esse sujeito configura-se nas identidades coletivas em contas de Twitter e Facebook e blogs de movimentos e coletivos independentes que relatam os protestos. Ao afirmar que o objetivo não era a quantidade de informações publicadas nos perfis, mas o estabelecimento de relações através do compartilhamento e da conexão entre pessoas e informações, Gutierrez explicita novas formas de relacionamento entre produtores e consumidores de informação, como quando Christofoletti e Laux (2008) relatam sobre da popularização dos blogs. A seleção e a filtragem de contas tem como base uma rede de compartilhamento e diálogo que nasce em meados de junho e embasa a constituição da plataforma a partir de conversações que não aparecem no site, mas pesam no momento da escolha de quais contas e blogs terão o conteúdo agregado no site. Quando Recuero (2003) menciona a plataforma Warblogs.cc a partir da necessidade de reunir o conteúdo de blogs sobre a Guerra no Iraque, percebe-se um movimento semelhante no @BRnasruas, mas ampliado na medida em que a agregação é feita não apenas de posts de blogs independentes, mas de diversas contas em sites de rede social que muitas vezes geram um volume grande de informação, dependendo da hashtag utilizada ${ }^{14}$. 
A quantidade de conteúdo é também um dos fatores que dificulta o trabalho do @BRnasruas. Como relata Gutierrez, o recolhimento de informações ainda é limitado a conteúdos com links, o que, por um lado facilita o trabalho, mas por outro exclui muita informação espalhada pela rede. Se no início dos anos 2000 Dreyfus (2001) considerava a quantidade de links uma dificuldade para encontrar e recuperar conteúdo online, no caso do @BRnasruas a inexistência de links impede o seu funcionamento. Aqui, o papel da folksonomia é fundamental para o funcionamento do site. As hashtags funcionam como agregadoras de conteúdo e orientam a formação da memória coletiva sobre os protestos, pois partem de fontes diversas. A filtragem feita através das hashtags é o aspecto que mais agrega coletividade ao conteúdo que aparece no @BRnasruas, pois além de serem utilizadas pelas contas coletivas selecionadas previamente, também são por perfis individuais, que podem assim alcançar visibilidade junto aos editores da plataforma. É fato, no entanto, que a escolha prévia das hashtags também limita a informação que circula na plataforma.

A escolha das hashtags é pautada pela popularidade das mesmas, o que indica que a memória coletiva em torno dos protestos, ao mesmo tempo em que é acessada por uma grande quantidade de pessoas, é nutrida por diversos perfis (CASALEGNO, 2006). Aqui a importância das relações sociais na construção de narrativa baseada em colaboração e engajamento coletivo impulsiona a plataforma que, ainda que não seja alimentada por todos, limitada ao poder dos editores, tem o conteúdo produzido por autores diversos. Os quadros sociais que Halbwachs (2004) menciona como referência para a reconstrução da memória são ativados através das hashtags, que reúnem diálogos e compartilhamentos independente da veiculação de informação praticada pela mídia de massa. A coletividade, ao utilizar as hashtags para marcar informações, dinamiza uma rede hipertextual semântica sobre os protestos. As conexões as quais Sepúlveda (2003) confere a responsabilidade pela formação da memória coletiva são resultado das relações sociais estabelecidas em redes sociais e blogs. Os links e as 
hashtags são os elos, o hipertexto que costura essa memória e permite o acesso aos conteúdos espalhados online.

A força que o hipertexto, através de links e hashtags, confere ao @BRnasruas o status de ferramenta capaz de contribuir para a formação de uma memória coletiva sobre os protestos. Segundo a classificação de Rösnay (2006), a memória explícita da plataforma decorre da memória implícita de perfis que atuam como identidades coletivas, e também de indivíduos, que distribuem informações na rede, marcando conteúdos através de links e hashtags e que dessa forma auxiliam a formação de memória coletiva sobre os protestos. Toda a liberdade garantida através da geração de links e hashtags, bem como das conversações geradas em torno dessa rede hipertextual, são fatores que dinamizam constantemente a memória coletiva que reside na plataforma. Ainda persistem obstáculos referentes à recuperação dessa memória. Um sistema de busca avançada auxiliaria no resgate de conteúdos que já apareceram no site, mas não figuram mais nas seções, e até mesmo para os que ainda circulam pelas seções. Gutierrez afirma que há um esforço no sentido de melhorar esse processo. Pode ser que a colaboração guie esse mecanismo, já que a plataforma funciona baseada na hipertextualidade de links e tags gerados por uma quantidade indefinida de indivíduos e identidades coletivas.

O funcionamento do @BRnasruastambém apresenta sobreposição de camadas física e digital que alimentam o site através de uma narrativa coletiva transmidiática, como aborda Toret (2012). A diversidade de conteúdos, ainda que previamente filtrada, fornece informações sob diferentes formatos, sobrepostos com diálogos e compartilhamentos que atestam caráter social ao processo de produção e circulação de informações e movimentam a memória coletiva sobre os protestos. Entende-se, diante desta descrição, que a plataforma @BRnasruas constitui uma ferramenta alternativa de consulta sobre os protestos, por quem quer que seja, jornalista ou não. 


\section{Considerações finais}

Buscou-se aqui abordar como a maneira pela qual a plataforma @BRnasruas contribui para a formação de uma memória coletiva sobre os protestos de junho de 2013 no Brasil. A ferramenta se apresenta como um espaço onde os conteúdos reunidos podem ser recuperados posteriormente, abrindo espaço para a configuração de um processo capaz de gerar memória coletiva em função de uma rede hipertextual movida por atores diversos, entre identidades coletivas e perfis individuais. Para o jornalismo, a ocorrência desse fluxo alternativo de informações acarreta mudanças na produção diária de notícias sobre os protestos. Além de servir como fonte de conteúdo, o @BRnasruas concorre, ou corre em paralelo, com o jornalismo da imprensa tradicional. A reunião de informações publicadas em contas de redes sociais e blogs independentes serve como pauta e modelo de comunicação, enquanto que a organização de conteúdo em sites e portais de notícias da mídia tradicional pode servir de exemplo e indício de soluções para deficiências de recuperação de conteúdo na plataforma. É preciso, no entanto, considerar as limitações do sistema em termos de filtragem e de recuperação das informações. A moderação poda oportunidades de participação tornando o sistema semi colaborativo; e a carência de mecanismos de busca interna prejudica o resgate de conteúdos já agregados.

Como já dito, padrões de rede vêm guiando a narrativa independente sobre os acontecimentos nas ruas do país. O espalhamento de informação por identidades coletivas interfere no fluxo midiático anteriormente controlado pela mídia de massa. A autoridade da narrativa é disputada pela mídia de massa, enquanto que a mídia independente, ao concentrar a centralidade das informações, demonstra por um modelo de comunicação diferente, mais democrático e transparente. A observação do @BRnasruas aponta traços desse esforço, ao mesmo tempo em que identifica ranços de um modelo distributivo moldado pelo controle. $O$ enfrentamento entre as mídias barra o desenvolvimento de 
um novo modelo, e por mais que alguns processos ainda dependam de amarras de moderação e filtro, o jornalismo ganha com a apropriação de ferramentas de comunicação digital orientadas pela colaboração e pelo engajamento.

\section{Referências}

BASTOS, M. T.; RECUERO, R.; ZAGO, G. Taking tweets to the streets. A spatial analysis of the Vinegar Protests in Brazil. In: First Monday, v.9,n.3, 2014. Disponível: http://goo.gl/xQnVVO

BOURDIEU, P. Questões de sociologia: algumas propriedades dos campos. Rio de Janeiro: Marco Zero, 1983.

CASALEGNO, F. Memória cotidiana: comunidades e comunicação da era das redes. Porto Alegre: Editora Sulina, 2006.

CASTELLS, M. Networks of outrage and hope: social movements in the internet age. Politik. Wiley, 2012.

CHRISTOFOLETTI, R.; LAUX, AP. Confiabilidade, credibilidade e reputação: no jornalismo e na blogosfera. In: Intercom - Revista Brasileira de Ciências da Comunicação,v. 31, n. 1, 2008. Disponível: http://goo.gl/2z2Rof

DREYFUS, H.L. On the Internet. Londres: Routledge, 2001.

DUARTE, J.; BARROS, A. (orgs). Métodos e técnicas de pesquisa em comunicação. Editora Atlas: São Paulo, 2008.

FRAGOSO, S.; RECUERO, R.; AMARAL, A. Métodos de pesquisa para Internet. Porto Alegre: Sulina, 2011.

GOHN, MGM. Movimentos sociais e redes de mobilização civis no Brasil contemporâneo. Ed. Vozes: Petrópolis, 2010.

GONDAR, J. Quatro proposições sobre memória social. In: DODEBEI, Vera; GONDAR, J. O que é memória social? Rio de Janeiro: Contra Capa, 2006.

GUTIERREZ, B. Três anos de revoltas conectadas. Disponível: http:// goo.gl/Al10A6

HALBWACHS, M. A memória coletiva. São Paulo: Centauro Editora, 2004.

LÉVY, P. O que é o virtual? Rio de Janeiro: 34, 1996.

LOTAN, G. et al. The Revolutions Were Tweeted: Information Flows during the 2011 Tunisian and Egyptian Revolutions. International Journal of Communications 5, Feature 1375-1405. 2011. Disponível em: http://goo.gl/ Gxrc72

MALINI, F. Imprensa nas redes sociais: autoridade sem centralidade. In: 
Blog do Laboratório de Estudos sobre Imagem e Cibercultura. Disponível em: http://goo.gl/aBknEb

MALINI, F.; ANTOUN, H. @internet e \#rua: ciberativismo e mobilização nas redes sociais. Editora Sulina, Porto Alegre, 2013.

NUNES, R. As manifestações renovarão os mecanismos existentes ou criarão novos? Entrevista especial com Rodrigo Nunes; In: Instituto Humanitas Unisinos. Disponível em: http://goo.gl/RWSeoB

RECUERO, R. Warblogs: os blogs, a Guerra do Iraque e o Jornalismo Online. In: Verso e Reverso, São Leopoldo, n.37, p. 57-76, 2003.

RECUERO, R. Contribuições da Análise de Redes Sociais para o Estudo das Redes Sociais na Internet: $O$ caso da hashtag \#Tamojuntodilma e \#CalabocaDilma. [versão preprint ] (publicada com a autorização da revista) - Revista Fronteiras, v. 16, p. 1, 2014. Disponível em: http://goo.gl/Anq1BE

RÖSNAY, J. Memória em rede e intercriatividade. In: CASALEGNO, Federico. Memória cotidiana: comunidades e comunicação da era das redes. Porto Alegre: Editora Sulina, 2006.

SEPÚLVEDA, M.S. Memória coletiva e teoria social. São Paulo: Annablume, 2003.

TORET, J. Una mirada tecnopolítica sobre los primeros dias del \#15M. In: Comunicación y Sociedad Civil. 2012. http://goo.gl/iR5U6p

VANDER WAL, T. Folksonomy definition and Wikipedia. Disponível em: http://goo.gl/ZQNptx.

ZAGO, G. Considerações sobre a circulação de informações em sites de redes sociais. Fonte (Belo Horizonte), v. 8, p. 70-77, 2011. 


\section{A HISTÓRIA NA TELEFICÇÃO: ECOS DO JORNAL A VOZ DA RAÇA NA CONSTRUÇÃO DA MEMÓRIA SOCIAL}

\section{THE HISTORY TELEFICÇÃO: ECHOES THE OFFICIAL VOICE OF THE RACE IN THE CONSTRUCTION OF SOCIAL MEMORY}

Niterói (RJ), v. 35, n. 3

dez/2016-mar/2017

A Revista Contracampo é uma revista eletrônica do Programa de Pós-Graduação em Comunicação da Universidade Federal Fluminense e tem como objetivo contribuir para a reflexão crítica em torno do campo midiático, atuando como espaço de circulação da pesquisa e do pensamento acadêmico.

\section{ROBÉRIA NÁDIA ARAÚJO NASCIMENTO}

Doutora em Educação pela Universidade Federal da Paraíba (2007). Mestre em Ciência da Informação pela Universidade Federal da Paraíba (2001). Professora Titular do curso de Comunicação Social (UEPB), vinculada aos Grupos de Pesquisa Comunicação, Cultura e Desenvolvimento e Comunicação, Memória e Cultura Popular, e à linha Mídia e Estudos Culturais. Brasil.

rnadia@terra.com.br

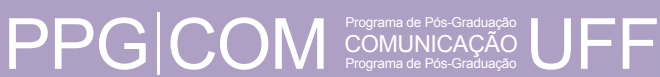

AO CITAR ESTE ARTIGO, UTILIZE A SEGUINTE REFERÊNCIA:

NASCIMENTO, Robéria Nádia Araújo. A história na teleficção: ecos do jornal A Voz da Raça na construção da memória social.

Contracampo, Niterói, v.35, n. 03, dez. 2016/ mar. 2017.

Enviado em: 27 de julho de 2015 / Aceito em: 26 de abril de 2016. 


\section{Resumo}

Este texto deriva de uma pesquisa que analisou a ressonância da ficção televisiva na valorização da religiosidade afro-brasileira e na visibilidade da pessoa negra na minissérie Tenda dos Milagres, inspirada na obra de Jorge Amado. A adaptação televisiva faz referência ao papel social do periódico A Voz da Raça, pertencente à Imprensa Negra, fundado em São Paulo nos anos de 1933. A abordagem busca demonstrar que o gênero ficcional, a partir de reconstituições históricas e dos fragmentos dos diálogos entre os personagens, pode se tornar um relevante espaço de fruição para se pensar as desigualdades raciais, as identidades coletivas (CUCHE, 2002; HALL, 2005) e os preconceitos étnicoreligiosos (GOFFMAN, 1988) contribuindo para a construção da memória social (LE GOFF, 2006; POLLAK, 2000).

\section{Palavras-chave}

Ficção televisiva; memória social; preconceito étnico-religioso

\section{Abstract}

This text comes from a study that examined the resonance of TV fiction in valuing religiosity afro-brazilian and the visibility of the black person in minisserie Tent of Miracles, inspired by the work of Jorge Amado. The television adaptation makes reference to the social role of the journal The Voice of Race, belonging to the Black Press, founded in Sao Paulo in the years to 1933 . The approach seeks to demonstrate that the fictional genre, from historical reconstructions and the fragments of the dialogs between the characters, can become an important area of enjoyment to think racial inequalities, the collective identities (CUCHE, 2002; HALL, 2005) and prejudices ethnic-religious (GOFFMAN, 1988) contributing to the construction of social memory (LE GOFF, 2006; POLLAK, 2000).

\section{Keywords}

TV Fiction; social memory; prejudice ethnic-religious 


\section{Introdução}

Este artigo deriva de uma pesquisa ${ }^{1}$ que analisou os arquétipos místico-religiosos e as contribuições da ficção televisiva para a valorização da religiosidade afro-brasileira e da visibilidade da pessoa negra na minissérie Tenda dos Milagres, baseada no romance homônimo de Jorge Amado, escrito em 1969. Para além da perspectiva do entretenimento, esse produto ficcional nos incita pensar nas condições de desigualdade social do contexto baiano nos anos de 1930. A historicidade dessa conjuntura, que se repetiu no país, foi atravessada pelo combate à miscigenação étnico-cultural e pelo ativismo de denúncia social enquanto mecanismos de superação das expropriações escravocratas, da discriminação de cor e de crença religiosa, causas defendidas pela Imprensa Negra, sobretudo nas páginas do periódico A Voz da Raça, cujos trechos são mencionados na minissérie.

A historiografia brasileira sobre o jornalismo ${ }^{2}$ aponta $A$ Voz da Raça como um dos relevantes veículos produzidos por negros e para negros, em razão de sua longevidade (1933-1937), estrutura e organização político-social, constituindo um eficiente canal por onde circulavam mensagens de liberdade, que ajudaram a escrever a história do movimento negro brasileiro e a imprimir o respeito pela identidade étnica em tempos de preconceitos e estereótipos. Parece-

\footnotetext{
1 Intitulada Os arquétipos místico-religiosos na ficção televisiva: o universo simbólico de Tenda dos Milagres, do Curso de Comunicação Social da UEPB com apoio do CNPq, concluída em 2012, incluindo João Saraiva da Silva Neto e Walquísia Raquelle Freire Gouveia, orientandos de Iniciação Científica. Versões derivadas do estudo foram apresentadas recentemente no I Simpósio Internacional Brasil e Itália, realizado entre 23 e 26 de agosto de 2015, na UEMA, no Maranhão, no Grupo Temático Diversidade Religiosa na Sociedade Secularizada, sob a mediação do Prof. Dr. Reginaldo Prandi. O nome da minissérie se refere à rudimentar tipografia de Lídio Corró (Milton Gonçalves), artesão de madeira, local que funciona como residência e ponto de encontro da boemia baiana. Agrega objetos que representam os milagres dos santos, feitos sob encomenda dos católicos beneficiados pelas graças alcançadas, como também acolhe as máquinas rotativas de impressão dos primeiros folhetos produzidos por Archanjo. Nesse ambiente sincrético entre o sagrado e o profano, o catolicismo e o candomblé, emergem a obstinação e a intelectualidade do protagonista, que se revolta contra as injustiças sociais e elabora os seus escritos, com o apoio da jornalista Ana Mercedes (Tânia Alves). A minissérie possui 30 capítulos e foi dirigida por Aguinaldo Silva e Regina Braga. Hoje, encontra-se reunida num Box de quatro DVDs, lançado pela empresa Globo Marcas.

2 No período colonial, já havia manifestos impressos dos negros. O tipógrafo Francisco de Paula Brito fundou no Rio de Janeiro o jornal "O Homem de Cor", que posteriormente recebeu o nome de "O Mulato", considerado precursor da Imprensa Negra do país. Jornais anteriores à Voz da Raça também exerceram um significativo papel de porta-voz dos direitos dos excluídos no Brasil, ajudando a compor a historiografia do movimento negro. Foram cerca de 30 em São Paulo: os periódicos A Pátria, O Propugnador, A Pérola, O Alfinete, A Liberdade, A Sentinela, O Clarim da Alvorada, Tribuna Negra, que reuniram entre seus colaboradores nomes da literatura e militantes da causa da negritude por justiça social.
} 
nos que a menção a esse periódico na ficção torna-se um registro histórico oportuno para atualizar as questões que perpassam a busca pela cidadania negra.

O periódico tinha formato tabloide, cujo conteúdo era distribuído em quatro páginas, preenchidas com artigos, notícias, notas, chamadas, informes, tendo por cabeçalho a frase, atribuída a Isaltino Veiga dos Santos: "O preconceito de cor, no Brasil, só nós, os negros, o podemos sentir". O jornal, fundado por Francisco Costa, integrante da Frente Negra Brasileira (FNB), publicou 70 edições, com periodicidade semanal no início, posteriormente quinzenal, e em 1937, década do seu encerramento, tornou-se um jornal mensal. Como documento oficial da FNB, derivado do seu teor discursivo-político em prol da emancipação da comunidade negra, foi extinto com a instauração do Estado Novo. Mais do que uma finalidade informativa, A Voz da Raça era um canal simbólico de diálogo e reivindicações dos negros, uma vez que seu maior propósito era instigar a superação do conformismo e da passividade dos marginalizados, combatendo o preconceito racial em suas diversas formas e disseminando uma visão positiva da ancestralidade negra. Na página dedicada às "Notícias e Destaques do Passado" eram discutidas questões relevantes sobre etnicidade. Por essas razões, pode ser considerado um instrumento de preservação da memória social brasileira, ao registrar o período histórico pós-abolição.

Sua proposta editorial tinha como palavras de ordem "Deus, Pátria, Raça e Família", homenageando abolicionistas como José do Patrocínio e Luiz Gama, além de figuras míticas, a exemplo de Zumbi, enaltecido por ter criado no Brasil um "Estado Perfeito", numa referência ao Quilombo dos Palmares. Todavia, o jornal era criticado pelos demais movimentos negros por representar linearmente a postura da FNB, comparando seus membros a "apóstolos modernos", e acusado de reproduzir a ideologia frentenegrina, constituindo uma discussão que não nos deteremos aqui.

Tratava-se de uma publicação inovadora para os padrões socioeconômicos da época, pois contava com sistema de assinaturas, 
distribuição para outros estados, impressão terceirizada, apresentando debates com intelectuais externos à comunidade negra, o que significava prestígio social. Suas páginas tinham espaço para arte, cultura, poesias e colunas escritas por mulheres, entre elas a "Rosas Negras". Temas como religiosidade afro-brasileira, samba, capoeira eram abordados como expressões africanas a serem respeitadas no espaço social.

No entanto, a preocupação do jornal com o nacionalismo sobressaia. Numa edição, lia-se: "Em São Paulo, há uma infinidade de negros desempregada. Os lugares são ocupados por estrangeiros. Há patrões e chefes de obras que não contratam operários brasileiros, sobretudo se são negros." (A VOZ DA RAÇA, n. 44, 1934, p.1). A edição seguinte reiterava "o desejo de construir uma identidade negra distinta da branca. A cultura e a história dos negros devem reerguer sua moral e contribuir para sua educação." (A VOZ DA RAÇA, n.45, 1934, p.2). Combatia as opiniões racistas e pejorativas manifestadas na imprensa regular, incentivando os negros a agir contra as injustiças.

Vale salientar ainda que atuou também na formação das sociabilidades negras. Correia (2004) explica que essa imprensa, de teor alternativo, surgiu de um jornalismo comunitário, que instiga a união e incorpora desejos e cobranças das esferas públicas locais ou ligadas a movimentos de caráter social. "Esses movimentos particularizam as informações dos periódicos, dando voz às expressões populares que não encontravam espaço na imprensa oficial, delineando suas identidades" (CORREIA, 2004, p. 193).

Conforme argumenta Cuche (2002), a identidade de um indivíduo se vincula a um sistema social, a uma classe, a uma nação, demarcando - lugar de onde o indivíduo fala e se percebe enquanto ser de sensibilidades e racionalidades. A ideia de identidade emerge, portanto, das experiências socialmente compartilhadas e das negociações de sentidos que, no período citado, auxiliaram a delinear o ativismo negro na escritura da história do povo brasileiro, nem sempre tecida pela valorização das diferenças. Nessa perspectiva, o autor defende que a afirmação da identidade legítima de um povo esboça o reconhecimento 
das especificidades culturais na luta contra a hegemonia social. No personagem Pedro Archanjo (Nelson Xavier), temos o exemplo do homem negro que luta pela visibilidade dos seus direitos e de seus costumes socioculturais num contexto em que as diferenças sociais e de crença religiosa são vistas como sinônimos de exclusão. Dessa forma, a narrativa da ficção forja o protagonismo da imprensa para dar vez e voz a indivíduos que não encontravam espaços de expressão na sociedade da época.

Pelos aspectos mencionados, Tenda dos Milagres é considerada uma obra sociológico-literária por representar a fase de engajamento de Jorge Amado às questões socioculturais, entrelaçadas com personagens atuantes nas causas da miscigenação e da cidadania dos negros, mediante o enfrentamento dos poderes e da inferioridade atribuída à negritude. Aborda a religiosidade ancestral, a partir do candomblé, articulando seus hibridismos e sincretismos, disseminando suas práticas nos imaginários populares, enquanto meios de enfrentamento dos preconceitos vividos pelos protagonistas. Na linguagem audiovisual, destacam-se os encontros e desencontros com a fé católica, bem como a perseguição da polícia aos cultos e rituais de matriz africana, notabilizados, sobretudo, nas cenas do terreiro de Majé Bassã (Chica Xavier). Na minissérie, há uma dinâmica de entrelaçamento que faz convergir as culturas, as religiões, os saberes, as raças, a luta pela igualdade social delineando questões que formatam a memória social coletiva.

De acordo com esse raciocínio, o universo da teleficção sugere algumas questões que nos parecem pertinentes: como um produto ficcional pode atuar na construção da memória? De que modo problematiza questões sociais, a exemplo do racismo? A complexidade dessas inquietações permeia este texto que, ao focalizar a narrativa amadiana, busca notabilizar o viés de denúncia das desigualdades e injustiças sociais que compõem os escritos do jornal $A$ Voz da Raça. 
Jorge Amado $^{3}$ é o escritor brasileiro mais conhecido no mundo por (re)criar imagens de um país singular e mestiço. Assim, Tenda dos Milagres, que também migrou para a tela do cinema (sob a direção de Nelson Pereira dos Santos, em 1977), é um dos exemplos de fruição mais bem sucedidos da transmutação de uma obra literária para a narrativa televisiva. A dramaturgia amadiana, de caráter atemporal, enfatiza a esperança na cultura popular, denunciando a exclusão social em seus diversos matizes, permitindo, com isso, o debate das interculturalidades, das alteridades humanas e da liberdade de crenças.

A personificação de Pedro Archanjo (cujo nome significa "anjo de ordem superior") reúne uma síntese de qualidades resilientes, ao enfrentar, corajosamente, o seu não saber na busca de fundamentação teórica para se contrapor às teses racistas que vigoravam na sociedade da época, contra-argumentando seu principal opositor o médico, Nilo Argolo (Oswaldo Loureiro). O catedrático da Faculdade de Medicina da Bahia afirmava em seus livros que os mestiços eram "seres indolentes, apáticos, impulsivos - por isso tenderiam ao crime, além de sexualmente perversos". Assim, entre estudos, leituras, rituais de fé e rituais profanos, o carisma e a personalidade solidária de Archanjo o levam a escrever livros, aprender idiomas, até que se torna bedel da Faculdade de Medicina, lugar onde conquista admiradores para a sua luta em prol da cidadania negra. Na minissérie, esse fato é forjado pela tematização místico-religiosa em torno dos poderes do orixá Xangô, que o nomeia "a luz do seu povo", inspirando-o a escrever sobre as injustiças para combatê-las. Desse modo, Jorge Amado fortalece seu herói permeando-o com as fraquezas e desafios humanos, aspectos que asseguram verossimilhança e acentuam reconhecimentos entre as classes sociais por ele representadas.

3 Segundo Goldstein (2003), o escritor nunca se definiu "antropólogo ou sociólogo", mas sempre o foi, mesmo sem querer ou saber. Considerado o livro preferido do autor, Tenda dos Milagres é seu $16^{\circ}$ romance, fundamentado em fatos históricos e traduzido para o alemão, espanhol, francês, húngaro, inglês, italiano. Trata-se de uma narrativa "paradigmática", em razão do cunho sociológico que a perpassa, sobretudo por expor as lutas dos subalternos contra os preconceitos instituídos pelo poder dominante. 
Apropriando-se dessa adaptação televisiva ${ }^{4}$ para pensar interfaces da memória com o universo cultural, este texto apresenta fragmentos do corpus de análise sobre o jornal mencionado e falas dos personagens. Com isso, temos a intenção de demonstrar que a ficção instiga reflexões e informa a sociedade sobre o papel histórico da imprensa nos movimentos populares.

\section{A construção da memória nos fluxos ficcionais: um Nordeste baiano?}

Vislumbrando a concepção de memória nos termos de Le Goff (2006), encontramos a ideia de fiç̧ão televisiva enquanto registro "documental, escrito, ilustrado, transmitido pelo som e imagem" (LE GOFF, 2006, p. 102). Nesse sentido, a produção ficcional se apropria da realidade para engendrar um processo marcado por relações de força que marcam uma determinada trajetória histórica. Portanto, não se trata de produções que buscam retratar apenas o passado, desvinculado dos dias de hoje, mas que estabelecem nexos e conexões do que ocorreu com a conjuntura presente. Desse raciocínio, emerge a possibilidade de que as imagens do cinema e da ficção em geral se coloquem como espaços de tessitura da memória e da história de uma época. Pollak (2000) defende que a narrativa audiovisual produz memória, porque essa categoria envolve uma operação coletiva de acontecimentos e interpretações que se pretende salvaguardar, a fim de reforçar, de uma maneira ou de outra, sentimentos de pertencimento e fronteiras sociais. Assim, falar de memória na sociedade via ficção implica analisar como um lugar ou um povo se define e se situa coletivamente em tempos diversos para inscrever sua história.

O conceito de memória não pode ser formulado de maneira unívoca e redutora, uma vez que é inacabado e se mostra em permanente

\footnotetext{
4 Na categoria "adaptação", segundo Nagamini (2004), estão implícitas as concepções de versão, inspiração, recriação, reatualização, aproveitamento temático, referência à obra, que resultam sempre num trabalho independente daquele que o originou. Nesse sentido, os possíveis diálogos entre a linguagem literária e a televisiva são entendidos neste texto como favoráveis à reconstituição da época retratada. Assim, não nos interessamos aqui em classificar estilo narrativo, apontar analogias, conjunções ou disjunções, mas destacar o caráter de conscientização fomentado pela minissérie.
} 
construção no espaço social, devido à polissemia que o constitui. Sob esse prisma, não se trata de desconsiderar as contribuições teóricas que primeiro traçaram o percurso de análise dessa categoria, mas de entendê-la na sua natureza de mobilidade, dadas as circunstâncias que fragmentam as memórias na vida contemporânea e a fluidez dos relatos. No final do século XX, Maurice Halbwachs a definiu como campo de investigação, buscando analisar como a coesão social se constrói a partir dos laços coletivos. Pelos quadros sociais de memória Halbwachs identificou unificação entre grupos familiares, religiosos, de classe. Entretanto, hoje essas relações sofrem intensas mudanças, então como se pensar em coesão? Mas quando discutiu as memórias coletivas, o teórico admitiu que há tantas memórias quanto os grupos que existem, o que já seria o prenúncio de uma ideia de multiplicidade em torno do conceito.

Pierre Nora é outro nome importante nessa discussão conceitual. Segundo ele, há lugares de memória que cumprem a função de transmitir valores, garantindo que a identidade nacional ou regional seja preservada. Esses lugares têm a função de contar histórias para que elas não se percam no tempo. No entendimento de Gondar (2005), Nora acenou com a possibilidade de tornar a concepção de memória social uma acepção de cunho transversal, uma vez que atravessa vários campos do conhecimento humano e diferentes saberes, não sendo relevante apenas para historiadores. É uma categoria em movimento, aberta a ser recriada, para além das definições estanques e lineares. "O conceito de memória, produzido no presente, é uma maneira de pensar o passado em função do futuro que se almeja" (GONDAR, 2005, p. 17). Trazendo esse pensamento para a nossa reflexão, de que modo Tenda dos Milagres poderia contar esse passado delineando aportes para se pensar o futuro? Argumenta a autora que nenhum documento jamais é inócuo: ele é sempre derivado de uma montagem específica de quem o produziu, como também da sociedade que tem acesso a ele. Nesse sentido, cada narrativa nos diz algo se a interrogarmos, se buscarmos sentido em seus ditos. Assim, a memória é acionada em 
razão de intencionalidades. O que Tenda dos Milagres pode nos dizer?

De acordo com tais posicionamentos, como a obra amadiana poderia ser útil para representar a memória nordestina? A Bahia poderia ser um ícone do Nordeste, segundo a retórica do escritor?

Jorge Amado, no entender de Albuquerque Júnior (2011), utiliza a ficção para "caracterizar o povo brasileiro, sua verdade interna, sua essência; preocupa-se em fazer o país enxergar o seu povo com seus suores, cantigas, macumbas, doenças, lutas, misérias, malandragens, captando as suas singularidades" (ALBUQUERQUE JÚNIOR, 2011, p. 239). Com uma narrativa inspirada no marxismo, a minissérie dá ênfase a um confronto maniqueísta entre as forças do bem (aludindo ao misticismo religioso de Archanjo e seus amigos) e do mal (representadas pela figura da polícia, através de Pedrito Gordo, e dos intelectuais, especialmente o médico Nilo Argolo com suas atitudes racistas). Entretanto, como esclarece o autor, quando se toma o Nordeste como tema de trabalho, existem nas abordagens imagens e enunciados frutos de várias estratégias de discursos que se cruzaram, de convenções que foram dadas, de uma ordenação de pensamentos consagrada historicamente. São, dessa forma, linguagens que reafirmam tipos e estereótipos construídos como essenciais: a seca, a pobreza, a desigualdade, a desesperança como signos da região, que por sua vez originam personagens que vencem seus desafios, mas que estão associados a figuras milagrosas. Temos a imagem de Xangô, atrelada à força de Pedro Archanjo, para quem a transferência de poder torna-se o único caminho para a superação das injustiças. Todavia, quando se reporta ao Nordeste, essa fragilidade humana sobressai e é como se fosse sempre insuficiente para combater o mal, necessitando por isso do arquétipo da coragem que permeia a divindade, de uma entidade mística para lhe salvar das atrocidades do mundo. "Nos discursos dos intelectuais da esquerda, como Jorge Amado, os mitos do Nordeste vão ser tomados a partir da dicotomia: civilização versus barbárie. Para esses discursos, o Nordeste sempre será mostrado como território de revolta" (ALBUQUERQUE JÚNIOR, 2011, p. 219). 
A importância da ancestralidade discutida pela minissérie, através da relação mágica de Pedro Archanjo com seu orixá, na verdade evoca não apenas elementos da memória afetiva do personagem, como também se mostra uma parábola para disseminar experiências factuais do período histórico retratado. A referência ao orixá Xangô tem uma mitologia própria, pois este é saudado nos terreiros como um rei. Suas insígnias são nobres: a coroa, o machado e o trono remetem ao seu poder, que é invocado na minissérie para aludir à luta contra o preconceito racial e a favor da liberdade de crenças, que seria empreendida pela liderança de Pedro Archanjo. Segundo a mitologia africana, o orixá teria sido um bravo guerreiro, sendo divinizado como herói após a sua morte numa batalha na qual defendia seu povo. A cólera conduz seu machado de duas faces para o enfrentamento dos inimigos, tornando-se o guardião das esperanças. Por essas razões, é venerado no Brasil como patrono do candomblé e representante da justiça social.

O desejo de preservar a memória está latente na problematização/ contextualização da obra. Pedro Archanjo foi inspirado na junção de dois ativistas políticos do mundo real: o escritor baiano Manuel Querino (abolicionista) e o Obá Miguel Santana (Babalorixá), defensores importantes da causa da liberdade religiosa na Bahia. O médico e antropólogo Nina Rodrigues, por sua vez, deu origem a Nilo Argolo (Oswaldo Loureiro), que se rebela contra as ideias vanguardistas do protagonista. Na narrativa, o caráter não fictício que perpassa fatos e personagens se dilui entre as criações do imaginário, permitindo a reconstituição histórica. Nesse sentido, Tenda dos Milagres reúne elementos biográficos, à medida que se entrelaça com o contexto da década de 1930, reproduzindo uma correlação perceptível nos diálogos, nos cenários, nos figurinos, nas ambientações dos capítulos. Essa problematização possível do gênero ficcional, segundo Lopes (2004), articula-se às ideias de mobilidade discursiva e plasticidade, pois pensamentos, imagens, símbolos, significados circulam por meio das narrativas ficcionais funcionando como chave de interpretação de 
processos identitários e abordagens sócio-histórico-culturais.

Na década retratada, a cultura do povo, os costumes, as tradições místico-religiosas são vistas como meios de intervenção da realidade, a religiosidade se misturando ao ativismo social como forma de enfrentamento das injustiças, dos preconceitos e da discriminação de crença religiosa. Tais forças populares se agregam e passam a constituir indícios da identidade regional, simbolizando a construção identitária como resultante da luta contra a exploração, a discriminação, o racismo. O Nordeste torna-se, no contexto baiano, um espaço-pretexto para homogeneizar as singularidades, promover generalidades. Tanto que muitos leitores ainda associam a região à espacialidade baiana, justamente pela descrição dos romances de Jorge Amado, que trazem a atmosfera mágica da superação das adversidades, da sensualidade das mulheres, das sociabilidades afetivas, sobretudo impulsionadas pelas imagens míticas do candomblé. Emerge, então, o misticismo como memória popular da luta pela liberdade social, que permanece viva no imaginário do público: a figura de Pedro Archanjo surge análoga a um herói da mestiçagem, defensor da religiosidade de seu povo. "São histórias que pretendem resumir coletividades, que pretendem ser emblemas para a memória de grupos ou classes. Com, isso Amado imprime ao regional uma dimensão universal, restaurando a face lírica da região" (ALBUQUERQUE JÚNIOR, 2011, p. 234).

\section{Nos fragmentos da minissérie, uma memória da história?}

Instaurando uma referencialidade realista, esse produto da ficção parte de traços históricos, fazendo emergir novos sentidos, que por sua vez inventam e reconstroem uma nova realidade pelos olhos dos espectadores. Quando narra a violência física e simbólica sofrida pelos negros e os conflitos religiosos, coloca em perspectiva a questão das identidades e das identificações em torno de um pertencimento social e religioso, fomentando as bases para uma reflexão na esfera pública. 
Do ponto de vista narrativo, Tenda dos Milagres visibiliza o letramento como possibilidade dessa transformação, apresentando um valioso investimento na escritura enquanto registro histórico dos indivíduos e preservação da memória das lutas culturais populares pela cidadania e a superação do racismo. A materialização dessa dinâmica, que mobiliza a solidariedade popular, ocorre através do personagem Pedro Archanjo. No diálogo com sua mãe de santo, que ora transcrevemos, esse foco se notabiliza:

Majé Bassã: Tu foi agraciado com um dom divino, Archanjo!
Do povo daqui, tu é um dos poucos que pode fazer alguma
coisa pela tua raça (...) Xangô tá falando, tá te ordenando
"tudo ver, tudo saber, tudo escrever". Tu foi escolhido para
ser Ojuobá, os "olhos de xangô"! Tu vai ser a luz do teu povo,
nossos olhos de ver, e nossa boca de falar, tu vai ser nossa
coragem e nosso entendimento. Tu vai dizer do nosso amanhã.
É por isso, meu filho, que tu pensa tanto em escrever, vive
anotando as coisas do teu povo, é porque xangô te escolheu.
Pode começar a cumprir tua obrigação, que já tá na hora!

O acréscimo do imaginário se mistura, portanto, a enunciações do mundo real, constituindo uma estratégia que confere verossimilhança às situações vividas pelos personagens, que reproduzem a história vivida pelo país naquele contexto. No capítulo 23, a jornalista Ana Mercedes lê palavras de Archanjo supostamente publicadas no jornal $A$ Voz da Raça: "A liberdade e o respeito às religiões católica e protestante devem ser assegurados também aos cultos afro-brasileiros. Seus adeptos devem ter sua crença respeitada dignamente quanto os milhares de cidadãos das outras correntes religiosas."

No Capítulo 33, Nilo Argolo lê a manchete: O monstro Argolo ensandeceu. "Alguém tem que dar um ponto final nessa história de imprensa negra! Deve haver alguma lei que proíba a circulação dessa nojeira! (...) Mas eu sei me defender dessa corja!". Publica então um artigo, que se inicia pelo seguinte texto: "A casta negra é atraso; a branca é progresso e evolução. Os mestiços são afetados pela demência".

Na mesma edição do jornal, Pedro Archanjo reitera seu discurso, atiçando ainda mais a ira do seu opositor: "Os sangues na Bahia não têm cor e se misturam de cima para baixo na hierarquia social. Portanto, 0 
preconceito de cor é uma ideia fora de lugar. Não são poucos nem fracos os que formam os grupos racistas: acadêmicos, autoridades do governo, proprietários rurais, médicos, intelectuais de diversos saberes. Porém, racismo é uma bandeira que devemos combater! Todos nós temos uma história que não tem cor! Nossos jovens, intelectuais ou não, devem preservar nossa memória, nossas raízes e não se envergonhar delas!". Com esse teor combativo, o periódico denuncia as questões atreladas ao preconceito racial e à liberdade de culto religioso. No contexto da época, esse jornal representou a cultura de resistência dos negros e mestiços, combatendo a premissa de que esses seriam obstáculo ao processo civilizatório brasileiro. Zaluar (1998) defende a cultura da imprensa alternativa como uma dinâmica de interação social contínua em que os símbolos coletivos e seus significados são reinterpretados. "Desse modo, o povo em união transmite seus valores fundados historicamente para as gerações futuras" (ZALUAR, 1998, p.119).

Contudo, a preocupação com a memória social na minissérie não permeia apenas as páginas do jornal, mas também emerge na representação do terreiro de Majé Bassã, palco de violência e perseguição das autoridades policiais. Vinagre Silva (2007) nos esclarece que os terreiros são espaços históricos que guardam as tradições e simbolizam a cultura oral dos afrodescendentes, configurando nichos de sociabilidade para o enfrentamento do preconceito e lugares de preservação da memória sociocultural. A geografia dos terreiros expressa, pois, uma ocupação sociopolítica, uma vez que os Ilês são casas religiosas, mas também espaços étnicos, de moradia, de acolhimento, de prestação de serviços assistenciais à coletividade. Para a autora, as relações afetivas de parentesco - consanguíneo e religioso-, articuladas às relações de gênero, interétnicas e de classe, modelam e regulam relações, não só religiosas, mas econômicas, socioculturais e ético-políticas. Desse modo, "as práticas são ressignificadas cotidianamente nesses territórios, formando elos entre o presente e o passado, entre o mundo contemporâneo real e o mundo mítico, elos entre o território religioso dos terreiros e a vida social" (VINAGRE SILVA, 2007, p. 5). 
A autora assinala que esses espaços valorizam e preservam a identidade cultural dos filhos de santo, uma vez que produzem a reafirmação étnica, incorporando indivíduos discriminados socialmente em outros espaços: negros/não-negros, homens/mulheres/crianças, indivíduos de diferentes orientações sexuais e pertencentes a distintas classes, inclusive os portadores de deficiência e de comprometimento mental, que não aceitos em outras práticas religiosas. "No terreiro de candomblé, os segmentos subalternizados da sociedade podem experimentar a possibilidade de ascensão social, e de desenvolvimento de uma nova sociabilidade, metamorfoseando seus lugares de desvantagem social com posições de prestígio na hierarquia religiosa" (VINAGRE SILVA, 2007, p. 6).

Dessa forma, segundo Albuquerque (2012), o candomblé preserva a herança africana no Brasil, que é repassada pela oralidade como fator de preservação da memória social com suas crenças e tradições. No fim do século XIX, o conhecimento dos velhos africanos, transmitido oralmente de geração a geração, já incorporara influências pagãs (formas de "feitiçaria") e cristãs (principalmente devoções) provindas da Península Ibérica, especialmente de Portugal. Assim, os terreiros funcionam enquanto tentativa de reafricanização das práticas simbólicas, locais onde se pratica o aprendizado dos idiomas, mantendo a memória da tradição e a preservação do patrimônio cultural das religiões de matrizes africanas, além de significarem adesão e pertencimento à crença dos ancestrais e à etnicidade afro.

Nesses ambientes religiosos, as mulheres, principalmente as negras, conforme ilustra a Mãe Majé Bassã, ocupam lugar de respeito na hierarquia, ao contrário do que se verifica em outras religiões. O terreiro ainda se constitui num espaço de permanência e resistência histórica dos afrodescendentes. Nesta territorialidade a matriz africana se perpetua a partir dos rituais, dos costumes, da culinária, da musicalidade dos atabaques, que mantêm viva a memória das crenças afro-brasileiras. A relação de Archanjo com sua mãe de santo, por sua vez, evoca um sentimento de reverência que é explicado com propriedade por Negrão 
(2009): "O candomblé é uma religião de memória, irmandade, de afetos, que valoriza os indivíduos, reforça suas identidades, integrando-os em uma família mística, que Ihes proporciona aconchego, amor e proteção filial" (NEGRÃO, 2009, p. 268).

Assim, Majé Bassã representa o afeto e a autoridade máxima nas questões da tradição religiosa. A ela é atribuído o arquétipo de "conhecimento" disseminador de memória, denominado de axé, bem como a missão de cuidar da vida de seus discípulos; conhecer seus amores, dramas e dificuldades; guiá-los nas mais diversas circunstâncias, trabalhando para curar males físicos e espirituais da comunidade religiosa com sabedoria e dedicação, orientando, enfim, as trajetórias de sua vasta "família de santos", que irão repassar adiante seus ensinamentos.

Medeiros (2012) assinala que não apenas os discursos, mas os figurinos e a reconstituição da época fazem da fiç̧ão veículos de construção da memória. As roupas e os objetos mobilizados são elementos detentores de "um impressionante poder intangível, de absorção de significados simbólicos, nos quais as memórias e as relações sociais são corporificadas, ganhando existência própria" (MEDEIROS, 2012, p. 158). As identidades, nesse processo, são transferidas para esses objetos, que passam a guardar histórias e contextos de determinadas épocas, provocando posterior reconhecimento entre os espectadores.

Essa problematização de símbolos da sociedade e das tradições culturais no gênero ficcional, segundo Lopes (2004), articula-se às ideias de mobilidade discursiva e plasticidade, pois pensamentos, imagens, símbolos, significados circulam por meio das narrativas ficcionais podendo tais questões funcionar como chave de interpretação de processos identitários e abordagens sócio-histórico-culturais. Nesse sentido, a lógica que move a ficção televisiva dá espaço a representações promovendo reflexões junto à esfera coletiva, cuja ressonância alimenta as discussões mostradas na tela da TV.

Nessa ótica, a ficção televisiva, por suas características de 
hibridismo e de preocupação com a identidade nacional, torna-se veículo de interculturalidade, podendo ativar a competência cultural, a socialização das experiências criativas e o reconhecimento das lutas populares, das diferenças e das alteridades (LOPES, 2004). Permite o conhecimento dos que os outros fazem, como pensam, como manifestam sua fé, quais seus pertencimentos étnicos, quais as expectativas e conflitos de diferentes gerações em diversos tempos históricos.

Ressaltando o poder de ressonância da ficção na esfera da audiência, a autora enfatiza que esse gênero adquire valor estratégico na criação e consolidação de novas identidades culturais compartilhadas, consistindo numa narrativa popular sobre a nação. Torna-se, assim, um lugar privilegiado na TV de onde se anuncia uma nação representada e não só "imaginada". "Histórias narradas pela televisão são, antes de tudo, importantes por seu significado cultural, oferecendo material precioso para se entender a cultura e a sociedade de que é expressão" (LOPES, 2004, p. 125). Na mesma direção, Silverstone (2002) reitera que as tramas ficcionais são nossa cultura e reflexo de nossa sociedade, "gostemos disso ou não, expressando as consistências e contradições da fantasia (...) oferecendo textos para que nós, suas audiências, nos posicionemos, nos identifiquemos" (SILVERSTONE, 2002, p. 82).

Nesse sentido, a verossimilhança das tramas é tecida no interior da narrativa, o que permite o fortalecimento das raízes do gênero ficcional em meio à sociedade e à cultura que o produzem. Corroborando essa assertiva, Bulhões (2009) postula: "A ficção não é um invólucro impenetrável, uma cápsula suspensa na imaterialidade: só pode transfigurar o real por tê-lo conhecido, por isso o subverte" (BULHÕES, 2009, p. 22).

Na ótica de Martín-Barbero (2004), a fruição estética do gênero ficcional apresenta ainda um aspecto significativo para além da intenção de verdade, da mobilização da memória e do imaginário do público, uma vez que por seu intermédio entendemos ainda as tradições específicas de um povo e as culturas mestiças dos países que são retratados. Por isso, a televisão se configura hoje como "o dispositivo mais 
sofisticado de modelagem e formação dos gostos populares, numa das mediações mais expressivas das matrizes narrativas do mundo cultural popular" (MARTÍN-BARBERO, 2004, p. 24). Exerce, dessa forma, papel estratégico na cultura cotidiana das maiorias, na transformação de suas sensibilidades, na construção de suas identidades. Nesse sentido, formata uma imagem estratégica de determinados universos do mundo real, possibilitando o reconhecimento entre a audiência, notabilizando "um modo comprometido" de ver, escutar ou ler uma dada historicidade.

Na esfera da identificação e da visibilidade, os gêneros ficcionais ainda se mostram em permanente estado de fluxo e redefinição, despertando novas inteligibilidades, mesclando particularidades, conformando novas sínteses sociais, restituindo e atualizando velhas histórias que são caras à cultura e à memória populares. Segundo Lopes, Borelli e Resende (2002), esses gêneros compreendem mitologias, reposições arquetípicas, matrizes culturais, estruturas narrativas que respondem pela possibilidade de elaboração de grandes totalidades do imaginário coletivo, "partilhando, como universalidades das construções imaginativas, do referencial de qualquer leitor, de qualquer receptor. São assim pontos de intercessão nas relações entre cultura popular, erudita e de massa" (LOPES; BORELLI; RESENDE, 2002, p. 254).

Hall (2005) assegura que a polissemia da TV dissemina uma pluralidade de ideias que podem salvaguardar uma dada historicidade. Motter (2004), em pensamento similar, destaca que os romances, as histórias de amor, correm em paralelo com o desenvolvimento de temáticas sociais, que são pinçadas do cotidiano, como também "questões embrionárias e nebulosas, marginalizadas como tabus, objetos de proscrição e silêncio, ou difusas, como mitos nascentes, objetos de temor, enlevação, encantamento e perplexidade". (MOTTER, 2004, p. 259).

De acordo com Gordillo (2010), a ficção desempenha importantes funções, sobretudo no sentido filogenético: reproduz desdobramentos e hibridações que suscitam reflexões, discussões e ressonâncias. Além disso, ainda permite: fabulização, numa tentativa de atrair as pessoas 
para outros contextos, mediante a ação de personagens, tempos e espaços (por modos de representação popular); socializadora, ao unir grupos sociais em torno de temáticas comuns, gerando adesões, gostos e preferências; função identitária, pois surge como intérprete da vida social, compartilhando os significados coletivos e expressando as mutações culturais; disseminadora de modelos, ao organizar situações e personagens familiares, convertendo os estereótipos em sugestões de comportamento social; função formativa, pois alguns relatos expõem mensagens educativas.

No capítulo 13, o preconceito com a mestiçagem é explícito, pois Pedro Archanjo comenta indignado com sua amiga Rosa de Oxalá (Dhu Moraes), que Nilo Argolo publicou infâmias na sua obra mais recente, intitulada "A degenerescência psíquica e mental dos povos mestiços". Pedro Archanjo [Exaltado, após a leitura]: - "Rosa, nós não somos degenerados em promiscuidade imunda, animais, ou pior, 'criminosos', como escreveu o professor de medicina! Um doutor que deveria se envergonhar desses insultos... Mas é mentira, Rosa, é calúnia desse sabe tudo que não sabe nada!"

Em retaliação a esse discurso, Pedro Archanjo sistematiza o seu primeiro livro, "A vida Popular na Bahia", iniciando a obra com uma frase emblemática, que dita o tom que inspirou a publicação: "É mestiça a face do povo brasileiro e é mestiça a sua cultura". Nesse livro, o protagonista repete um pensamento do poeta Manoel Querino, que inspirou o personagem: "O Brasil possui duas grandezas reais: a uberdade do solo e o talento do mestiço". O jornal A Voz da Raça publica um manifesto de apoio ao livro de Archanjo, convocando os leitores à adesão à causa.

O delegado Pedrito Gordo (Claúdio Mamberti) também expressava publicamente seu pensamento racista nas entrevistas que concedia ao jornal: "Não sou eu. São os mestres da Bahia que afirmam a alta periculosidade da negralhada. Eu apenas trato de cortar o mal pela raiz evitando que ele se propague! Cadeia neles!" Na verdade, as religiões de origem africana no Brasil enfrentaram discriminação e a repressão 
policial embasada na lei, que perdurou até a década de 1970 , do século $X X$, quando então a violência física contra os adeptos foi refreada, resultado de uma luta vitoriosa dos integrantes das religiões afrobrasileiras pela inclusão constitucional (ISAIA; MANOEL, 2012).

Por muitas décadas, foram estigmatizados como grupos de charlatães ou feiticeiros, tendo as suas práticas de religiosidade colocadas no patamar de bruxaria e à margem das religiões oficiais. Na concepção de Goffman (1988), o estigma é a situação do indivíduo que está inabilitado para a aceitação social plena. Trata-se de um termo profundamente depreciativo, que nega a possibilidade de relações e se refere a atributos. Os preconceitos derivam dos estigmas e se atravessam nas diferentes esferas sociais. Na visão do autor, o preconceito se contrapõe às qualidades de caráter, como lealdade, compromisso, honestidade, propósitos que (re)afirmam valores atemporais e regras éticas, produzindo espaço para a exclusão social, a violência e a discriminação. Os estigmas tribais de raça, nação e religião podem ser transmitidos através de uma linhagem e contaminar por igual todos os membros de uma mesma família.

Na minissérie, o candomblé é visto como "magia dos negros" pelas autoridades policiais e acadêmicas, o que os torna discriminados aos olhos da sociedade. "Nos processos de socialização e nas interações sociais e religiosas, surgem, da parte dos excluídos, sentimentos de medo, vergonha, humilhação, impureza, contaminação" (GOFFMAN, 1988 , p. 14), o que gera afastamento social.

No entanto, Capelato (2007) adverte que existem imagens padrões, identificadas como ícones "canônicos", ligadas a conceitoschave cristalizados na vida social. Então, é preciso atenção para que tais imagens, atuando como referências inconscientes, não produzam efeitos subliminares de identificação coletiva, do ponto de vista pejorativo ou negativo. Em outras palavras, as imagens mostradas na minissérie podem ser entendidas enquanto valorização das tradições e lutas dos negros contra o racismo, mas, por outro lado, também podem alimentar estereótipos que associam os negros somente à vitimização, 
esquecendo-se de realçar suas qualidades resilientes. Todavia, esse debate, que atrela a África e seus descendentes a adjetivos inferiores no contexto histórico, é oportuno e relevante, porém ultrapassa os limites e as pretensões deste artigo.

Torna-se válido ressaltar que somente em 1985, período da exibição da minissérie, as mais importantes Ialorixás de Salvador, Mãe Stella do Axé Opô Afonjá, Mãe Menininha do Gantois e Mãe Olga do Alaqueto, divulgaram na imprensa nacional, com efetivo apoio do Movimento Negro da Bahia e dos Grupos de Direitos Humanos, um documento pelo qual afirmavam que o candomblé não é uma manifestação folclórica, uma seita, ou uma religião selvagem e primitiva. Esse pronunciamento a favor da valorização do negro e de suas crenças, que também ocorria em nível internacional, se refletiu em Salvador, o que resultou numa série de medidas oficiais visando à preservação da cultura e da memória africanas em todo o país (NEGRÃO, 2009). Nesses termos, a minissérie contribuiu para visibilizar tais questões no espaço social.

A articulação da memória individual e da memória coletiva tratase, conforme explica Gondar (2005), de uma intervenção cognitiva sistemática, pois ao ligar imagens e fatos com acontecimentos do passado, desenvolvemos três operações: ação intelectual que associa as lembranças por atribuição de significados; ação de rememoração, que liga e identifica experiências passadas a fatos presentes; e ação de compartilhamento, à medida que discutimos e repassamos aos outros fatos vividos, cujas similaridades repetem situações conhecidas. Nesse raciocínio, é o tempo que proporciona o sentido das memórias dos grupos sociais. Cada realidade fornece singularidades simbólicas, discursivas e relacionais que ativam a compreensão de contextos e situações históricas. A memória social, portanto, se inscreve num processo de circulação e ressignificação que ordena e classifica os fatos segundo critérios sociais de mediação de significados. Assim, a memória torna-se elemento essencial da construção da identidade de um grupo, do sentimento de continuidade e coerência que reconstrói 
uma coletividade e escreve sua história ao longo das transformações vividas que permitirão ativação das lembranças e reconhecimento.

\section{Considerações Finais}

A pesquisa apontou que a teledramaturgia pode funcionar como espaço de interlocução para importantes problematizações, expressando as mudanças, tensões, contradições e singularidades próprias de um país multicultural. Apresentando elos com a obra literária que a inspirou, Tenda dos Milagres revela sua intertextualidade, discutindo a prática do candomblé em meio às dificuldades privadas das relações humanas e familiares, atrelando-se aos fatos amorosos, afetivos e políticos do contexto retratado, a exemplo das situações que apontam o preconceito e a perseguição aos negros, noticiadas pelo jornal $A$ Voz da Raça e disseminadas nos livros de Pedro Archanjo.

Compreendida por esse ângulo, a produção visibiliza as referências históricas e humanas dos agentes sociais que escreveram o passado nordestino, com suas expectativas e lutas, a exemplo dos afrodescendentes. Em sua plasticidade e apropriações narrativas, dissemina a valorização da cultura negra e da sociabilidade baiana, instigando uma racionalidade sensível para o universo simbólico do candomblé, ao passo em que forja uma reflexão histórica sobre a discriminação que permeia essa prática religiosa, sobretudo quando retrata os estigmas religiosos do início do século XX.

Engendrado que foi nas entranhas da escravidão, o fenômeno do candomblé encontra-se, desde seus primórdios, ligado à inserção do negro na sociedade brasileira e a sua capacidade de resiliência. Assim, as mensagens de Tenda dos Milagres são verossímeis, transcendendo a temporalidade em que foram escritas, permitindo a circulação, apropriação e interação de novas práticas simbólicas, reelaborando os sentidos da participação popular, da ressonância da história do povo negro e nordestino, emblemático e singular no enfrentamento dos estigmas raciais que o perpassam. Conta uma história, cujos 
ecos e reivindicações permearam a trajetória do jornalismo, enquanto relevante espaço de preservação da memória social e democratização das lutas em prol da cidadania.

\section{REFERÊNCIAS}

ALBUQUERQUE, Paulo Roberto Lopes de. Os símbolos de Xangô. IN: MIELE, Neide (Org). Religiões, múltiplos territórios. João Pessoa: Editora UFPB, 2012.

ALBUQUERQUE JÚNIOR, Durval Muniz de. A invenção do Nordeste e outras artes. 5a ed. São Paulo: Cortez, 2011.

BULHÕES, Marcelo. A ficção nas mídias: um curso sobre a narrativa nos meios audiovisuais. São Paulo: Ática, 2009.

CAPELATO, Maria Helena et al. História e cinema: dimensões históricas do audiovisual. São Paulo: Alameda, 2007.

CORREIA, João Carlos. De que modo a noção de espaço público altera-se e afeta o jornalismo cultural? In: BRASIL, André (Org). Cultura em fluxo: novas mediações em rede. Belo Horizonte: Editora PucMinas, 2004.

CUCHE, Denys. A noção de cultura nas ciências sociais. Tradução: Viviane Ribeiro. $2^{a}$ ed. Bauru: EDUSC, 2002.

GOFFMAN, Erving. Estigma: notas sobre a manipulação da identidade deteriorada. Rio de Janeiro: Guanabara, 1988.

GOLDSTEIN, Ilana. O Brasil best seller de Jorge Amado: literatura e identidade nacional. São Paulo: Editora Senac, 2003.

GONDAR, Jô. Quatro proposições sobre memória social. In: GONDAR, Jô; DODEBEI, Vera (Orgs). O que é memória social? Rio de Janeiro: Contra Capa Livraria, 2005.

GORDILLO, Inmaculada. Manual de narrativa televisiva. Madrid: Editorial Sintesis, 2010.

HALL, Stuart. A identidade cultural na pós-modernidade. Rio de Janeiro: DP\&A, 2005.

ISAIA, Artur Cesar; MANOEL, Ivan Aparecido (orgs.). Espiritismo \& religiões afro-brasileiras: história e ciências sociais. São Paulo: Uniesp, 2012.

LE GOFF, Jacques. História e memória. Campinas: UNICAMP, 2006.

LOPES, Maria Immacolata Vassalo de; BORELLI, Silvia Helena Simões; RESENDE, Vera da Rocha. Vivendo com a telenovela. São Paulo: Summus Editorial, 2002. 
LOPES, Maria Immacolata Vassalo de. Para uma revisão das identidades coletivas em tempos de globalização. In: LOPES, Maria Immacolata Vassalo de (Org). Telenovela: internacionalização e interculturalidade. São Paulo: Edições Loyola, 2004.

MARTÍN-BARBERO, Jesús. Viagens da telenovela: dos muitos modos de viajar em, por, desde e com a telenovela. In: LOPES, Maria Immacolata Vassalo de (Org). Telenovela: internacionalização e interculturalidade. São Paulo: Edições Loyola, 2004.

MEDEIROS, Cléryston Raffael Wanderley de. Memória e esquecimento na pós modernidade. In: BURITI, Iranilson (Org). Identidades e sensibilidades: 0 cinema como espaço de leituras. Campina Grande: EDUEPB, 2012.

MOTTER, Maria Lourdes. Mecanismos de renovação do gênero telenovela: empréstimos e doações. In: LOPES, Maria Immacolata Vassalo de (Org). Telenovela: internacionalização e interculturalidade. São Paulo: Edições Loyola, 2004.

NAGAMINI, Eliana. Literatura, televisão, escola: estratégias para leitura de adaptações. São Paulo: Cortez Editora, 2004.

NEGRÃO, Lísias Nogueira (Org). Novas tramas do sagrado: trajetórias e multiplicidades. São Paulo: Editora FAPESP, 2009.

POLLAK, Michael. Memória e identidade social. Estudos Históricos. São Paulo: PUC, 2000.

SILVERSTONE, Roger. Por que estudar a mídia? São Paulo: Edições Loyola, 2002.

VINAGRE SILVA, Marlise. O exercício do poder feminino na tradição étnico-religiosa iorubá no Brasil: uma estratégia para concretizar direitos em uma sociedade globalizada e desigual. CBASS. Artigo. Foz Do Iguaçu, 2007.

ZALUAR, Alba. Teoria e prática do trabalho de campo. In: CARDOSO, Ruth. A aventura antropológica. Rio de Janeiro: Paz e Terra, 1998. 

MUNDIAL: APROPRIAÇÕES DA MEMÓRIA COLETIVA PELA PUBLICIDADE BRITÂNICA NO ANO DO CENTENÁRIO [1914 - 2014]

\section{REMEMBERING WORLD WAR I: APPROPRIATIONS OF COLLECTIVE \\ MEMORY BY BRITISH ADVERTISEMENT IN THE YEAR OF ITS CENTENARY}

Edição v.35 número 3 / 2016-17

Contracampo e-ISSN 2238-2577 Niterói (RJ), v. 35, n. 3

dez/2016-mar/2017

A Revista Contracampo é uma revista eletrônica do Programa de Pós-Graduação em Comunicação da Universidade Federal Fluminense e tem como objetivo contribuir para a reflexão crítica em torno do campo midiático, atuando como espaço de circulação da pesquisa e do pensamento acadêmico.

\section{GISELA G. S. CASTRO}

Docente Titular do Programa de Pós-Graduação em Comunicação e Práticas de Consumo da ESPM, São Paulo, com pesquisas sobre comunicação, consumo e entretenimento. Brasil.

gcastro@espm.br

\section{VERA DA CUNHA PASQQUALIN}

Mestre em Comunicação e Práticas de Consumo (ESPM, São Paulo), com dissertação sobre comunicação, consumo e memória. Brasil.

vpasqualin@gmail.com

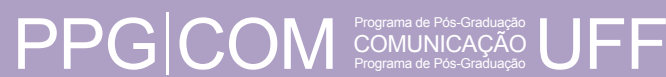

AO CITAR ESTE ARTIGO, UTILIZE A SEGUINTE REFERÊNCIA:

CASTRO, Gisela G. S.; PASQUALIN, Vera da Cunha. Rememorando a Primeira Guerra Mundial: apropriações da memória coletiva pela publicidade britânica no ano do centenário (1914 - 2014) Contracampo, Niterói, v. 35, n. 03, dez. $2016 /$ mar. 2017. 


\section{Resumo}

Este artigo examina duas campanhas publicitárias veiculadas no Reino Unido no ano em que se comemorou os 100 anos da eclosão da Primeira Guerra Mundial. As lembranças dos que lutaram nos campos de batalha fornecem matéria-prima para ambas as produções. Interessa-nos discutir como a memória coletiva é acionada estrategicamente para estabelecer conexões entre 0 anunciante e 0 legado afetivo da efeméride. Em ambos os casos, a própria publicidade se torna produto de consumo, tendo os comerciais sido amplamente comentados e compartilhados nas redes sociais online. Ressaltando a diferença entre memória e arquivo, destaca-se a dimensão propriamente afetiva da memória, a conexão entre memória individual e coletiva, bem como a relevância da memória como patrimônio na manutenção dos vínculos sociais. Por fim, problematiza-se o uso estratégico da memória social nas lógicas de consumo.

\section{Palavras-chave}

Comunicação e consumo; memória; publicidade; Primeira Guerra Mundial

\section{Abstract}

This paper examines two advertising campaigns released in the UK in the centennial of the outbreak of the First World War. Memories from those who fought in the battlegrounds provide raw material for both of these productions. We discuss the ways in which collective memory is strategically triggered in order to establish a connection between advertiser and the affective legacy of the celebration. Both commercials became products of consumption. These ads were widely commented and shared online. We highlight the difference between archive and memory, by stressing the affective dimension of memory, the connection between individual and collective memory and the relevance of memory as heritage in maintaining social bonds. In the end, we problematize the strategic use of social memory in the logics of consumption.

\section{Keywords}

Communication and consumption; memory; advertising; First World War 


\section{Introdução}

No intuito de dialogar com o instigante tema proposto pelos editores deste periódico, este artigo discorre sobre duas marcantes campanhas publicitárias veiculadas no Reino Unido em 2014. O ano foi marcado por grande mobilização das instâncias culturais em Londres, pela passagem dos 70 anos do Dia $\mathrm{D}$, evento relacionado à invasão da Normandia, que culminou no término da Segunda Grande Guerra, em 1945, e os 100 anos da eclosão da Primeira Guerra Mundial, em 1914.

Aproveitando as comemorações que marcaram o centenário, cada uma das campanhas aqui discutidas tematizou, a seu modo, a complexa teia de memórias relacionadas com a efeméride, em um contexto marcado a fundo pelo conflito que, na ocasião, foi imaginado como aquele que iria acabar com todas as guerras. As lembranças dos que efetivamente lutaram nos campos de batalha fornecem matériaprima para ambas as produções.

Parte das comemorações envolveu vultoso investimento na completa reestruturação do Imperial War Museum (IWM), criado em Londres durante a Primeira Grande e conhecido por abrigar o maior acervo de objetos relacionados com este conflito. A primeira peça estudada foi produzida para divulgar a reabertura do IWM, com novas mostras especificamente dedicadas às reminiscências dos combatentes. Em seguida, a atenção se volta para a campanha natalina de um anunciante do setor de varejo. Neste comercial, soldados alemães e britânicos protagonizam um breve momento de trégua no Natal de 1914.

Em cada uma dessas narrativas publicitárias pretendemos analisar as conexões entre o anunciante e o legado afetivo associado à Primeira Grande Guerra. No entanto, como veremos a seguir, há mais contrastes do que semelhanças entre as duas campanhas. Em ambos os casos, a publicidade se oferece, ela própria, como produto de consumo. Os dois comerciais foram amplamente visualizados, comentados e compartilhados nas redes sociais online, tendo se tornado 
peças memoráveis.

Entretanto, enquanto no primeiro caso trata-se de publicidade de cunho social, tendo como anunciante o patrimônio público de um museu em homenagem aos que se sacrificaram em prol da pátria, no segundo caso, a comoção das comemorações serve de mote para a agência AMV BBDO trabalhar a imagem pública de uma rede de supermercados. Interessa-nos, portanto, discutir os modos de apropriação da memória coletiva acionados, de modo estratégico, nestas campanhas e o espraiamento das lógicas de consumo na vida social.

\section{0 voo das narrativas}

Flight of the stories ${ }^{1}$, a comovente campanha promocional que marcou a reinauguração do IWM, foi produzida pelo premiado estúdio Aardman² e alude à nova fase das exposições sobre a Primeira Guerra Mundial. Durante décadas, as visitas a este museu eram guiadas pessoalmente por ex-combatentes que interagiam com os visitantes, oferecendo testemunho em primeira mão. Após a grande reforma, mostras interativas substituem o contato direto. Dentre as atrações das novas galerias dedicadas ao conflito, gravações de relatos da guerra nas trincheiras, escritas por soldados e oficiais britânicos em diários pessoais e cartas enviadas para suas famílias.

O comercial utiliza a técnica de animação com base em aquarelas, que conferem à narrativa uma forma fluida, suave e bela. Em contraste à dura crueldade dos campos de batalha, a escolha dos temas e cores das ilustrações prima pela leveza e evoca a atmosfera lúdica dos contos de fadas. A animação mostra pequenas figuras em forma de aspas que brotam da terra, juntam-se aos pares para se tornarem aladas fazendo lembrar certos modelos de fones de ouvido - e alçam voo até Londres, onde serão eternizadas.

Figura 1: Narrativas em voo sobre Londres

Disponível em: https://www.youtube.com/watch?v=-IZUTMS8uLA. Último acesso: 31/08/ 2016.

Responsável pelo premiadíssimo Fuga das Galinhas (Chicken Run, 2000), dentre outros sucessos. 


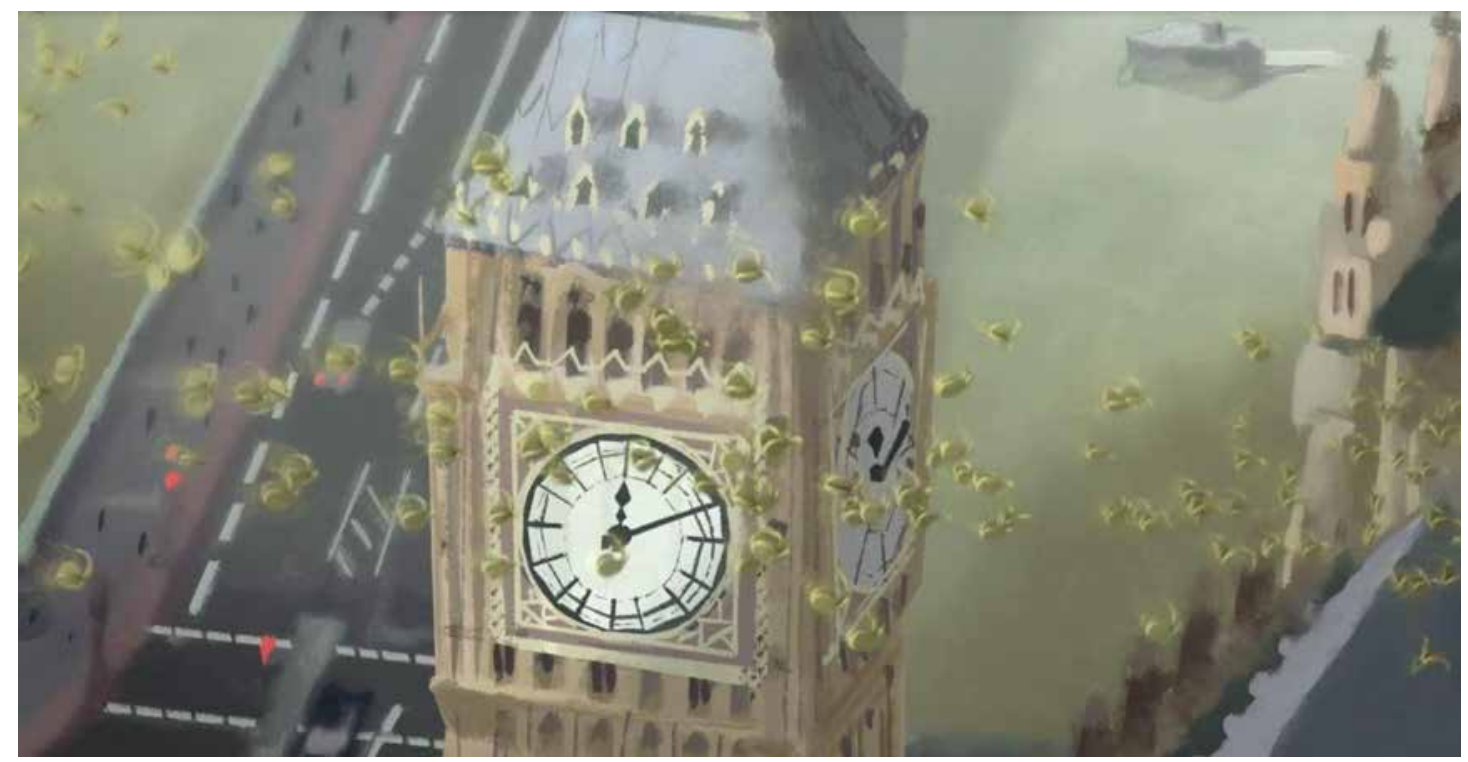

Fonte: www.aardman.com

Na viagem das narrativas que ajudam a remontar a História, diversos relatos dos combatentes da guerra que formam um mosaico de fatos que vêm a se tornar institucionalizados. Aqui entendemos o museu como instituição guardiã desta memória. Publicação desenvolvida pelo ICOM - International Council of Museums, traz a definição de museu como

uma instituição permanente, sem fins lucrativos, a serviço da sociedade e do seu desenvolvimento, aberta ao público, que adquire, conserva, estuda, expõe e transmite o patrimônio material e imaterial da humanidade e do seu meio, com fins de estudo, educação e deleite (DESVALLÉES; MAIRESSE 2013, p. 64).

À luz deste conceito, podemos entender que as memórias adquirem uma dimensão social. Os objetos e as narrativas expostos nas novas galerias do IWM passam pelo que diz Maria Cristina Castilho Costa, quando aborda a transformação dos objetos do cotidiano, que ultrapassam suas funções práticas e adquirem novos significados para a construção da memória histórica.

Assim é que os acervos domésticos são criados por objetos que não sendo retirados do seu ciclo de vida útil para serem preservados, conservados e legados à posteridade. Eles perdem efetivamente sua função prática e funcional, mas adquirem outra, ou seja, a de serem testemunhos da trajetória de vida de uma pessoa ou de uma família, assumindo a função 
histórica (COSTA, 1995, p. 40).

Os objetos expostos neste museu são os mais variados possíveis e vão desde tanques de guerra até singelas peças domésticas que refletem as restrições impostas pelo racionamento de víveres. Cada objeto, portanto, carrega um novo significado para que o visitante do museu compreenda o que foi esta guerra e suas repercussões. Complementando a exposição dos objetos, a coleção digitalizada de relatos narrados por profissionais favorece a imersão do visitante na dimensão humana comumente ofuscada pelo horror das batalhas.

No momento em que o distanciamento cronológico inviabiliza a presença física de veteranos de guerra nas dependências do museu, a iniciativa de produzir esta coleção favorece neste artigo "uma reflexão em torno dos novos sentidos da memória e das tecnologias de memorização na contemporaneidade" (BEIGUELMAN, 2014, p. 31).

Ainda que de modo indireto, talvez se possa dizer que o comercial reforça a importância do museu como local de educação. Atividades educativas se prestam a ensinar o visitante a aprender com a guerra, com o objetivo de promover a paz. Aprender com o passado para se construir o futuro. Novamente recorremos aos conceitos-chave da Museologia:

A educação museal pode ser definida como um conjunto de valores, de conceitos, de saberes e de práticas que têm como fim o desenvolvimento do visitante; como um trabalho de aculturação, ela apoia-se notadamente sobre a pedagogia, 0 desenvolvimento, o florescimento e a aprendizagem de novos saberes (DESVALLÉES; MAIRESSE, 2013, p. 38).

O sítio eletrônico ${ }^{3}$ deste museu informa que são recebidos dois milhões de visitantes por ano, sendo seiscentas mil crianças participando de programas educativos. Para entender o papel educativo deste tipo de instituição, especialmente um museu sobre a guerra, é necessário recorrer à vigorosa originalidade do pensamento sobre o eterno retorno em Nietzsche. Maria Cristina Franco Ferraz explica que o filósofo

indica a via para a superação do peso de um passado irrecorrível, que transforma todo o viver em castigo e

3 Disponível em http://www.iwm.org.uk/visits/iwm-london Acesso em: 15/08/2016. 
punição. Sugere, em contrapartida, um ousado e trágico 'assim eu o quis', acrescido de uma afirmação ainda mais radical, projetando o querer tanto para trás quanto para frente: 'assim eu vou querer' (FERRAZ 2010, p. 109-110).

Nesse sentido, a memória do que houve pode servir de aprendizado sobre os fatos do passado para que possamos projetar nosso futuro como queremos. Construção alicerçada nas lições, boas ou más, do que aconteceu anteriormente

\section{O consumo da memória}

O filme de animação mencionado acima convoca para a visitação do museu, um consumo simbólico, estímulo à reflexão sobre o passado, mas também com uma motivação financeira. O consumo de mostras em museus "é aqui entendido a partir dos conceitos trazidos por teóricos como Néstor García Canclini, que compreende o consumo como uma ação política, como uma prática que transforma consumidores em cidadãos" (PASQUALIN, 2014, p. 204). Especialmente se pensarmos na singularidade do IWM, pode-se considerar que o visitante deve ter a chance de refletir, em maior ou menor grau, sobre o papel dos conflitos e sobre seus impactos até os dias de hoje, de modo a se posicionar em ações e ocasiões futuras.

Como é praxe em todos os museus londrinos, a entrada no IWM é franca, porém existe toda uma lógica de consumo que associa o material e o simbólico ao fluxo de visitantes que ali ingressa. Há no local uma loja com artigos vintage. Quando tomam contato com os conteúdos apresentados nas galerias do museu, os visitantes saem tocados com o estilo vigente à época retratado nas exposições e são estimulados ao consumo de produtos que representem este momento histórico. Podem tirar suas libras da carteira e levar um souvenir para casa. Por sua vez, a lanchonete do museu também ressalta o uso de receitas tradicionais, reforçando que a cultura nacional é importante e que aquele é um local para marcar a identidade cultural da GrãBretanha. 
Além dos estímulos ao consumo cultural e material mencionados acima, é importante também perceber que quanto maior o número de visitantes, maior a chance de recursos de patrocínio e doações. O IWM aceita doações de pessoas físicas, que podem fazer uma contribuição esporádica, periódica ou tornar-se patronos da instituição. O museu oferece ainda uma série de benefícios específicos para o apoio financeiro de empresas, que vão desde filiação até patrocínio de mostras específicas, passando pela locação de espaço para ações corporativas.

Em filme ${ }^{4}$ sobre os bastidores da produção do comercial sobre a reabertura do IWM, ressalta-se que, para o visitante, a História se torna mais marcante quando relacionada a objetos físicos que podem enxergar e, eventualmente, manusear. As exposições interativas sobre os ex-combatentes reforçam essa ideia.

Entende-se que a bela campanha promocional das memórias em voo serve de estímulo à visitação mais numerosa. Por consequência, o grande fluxo de consumidores em potencial facilitaria a conquista de novos parceiros financeiros. Seja a partir do que está exposto nas galerias do museu, ou por meio das "lembrancinhas" compradas na loja da instituição, os objetos associados à guerra evocam a memória cultural coletiva e adquirem a função de promover a reflexão e, ainda, uma certa comunhão com aqueles que lutaram pela nação.

\section{Compartilhe... o chocolate}

O museu é um lugar legitimado como guardião da memória. Em contraste, algo diverso acontece quando a memória da guerra, que atingiu de forma tão veemente nações tão diversas, é apropriada como argumento de vendas em uma rede de supermercados. Embora reconhecida como uma produção primorosa, a apropriação comercial desta memória cultural na publicidade $^{5}$ de uma grande rede de

\footnotetext{
4 Disponível em: https://www.youtube.com/watch?v=QanQE0J0s4Y. Acesso em: 15/08/2016.

5 Disponível em: https://www.theguardian.com/media/2014/nov/13/sainsburys-christmas-advertrecreates-first-world-war-truce Acesso em 15/08/2016.
} 
supermercados britânicos gerou polêmica, que ganhou cobertura na imprensa ${ }^{6}$ local.

Embora tomada emprestada de outro contexto, mais diretamente ligado às redes digitais, a ponderação de Giselle Beiguelman faz sentido nesta discussão:

não se pode deixar de chamar a atenção (...) para o fato de que a memória cultural hoje é também uma questão econômica e um serviço. Deveria, por isso, demandar algum tipo de código ético. Afinal, cada vez mais as memórias, pessoais e coletivas, públicas e privadas, são mediadas por instâncias corporativas (BEIGUELMAN, 2014, p. 20).

Voltando ao comercial, a peça é toda marcada por cenas nas quais se depreende apenas um lado fraternal e esterilizado da história. De certo modo, passa-se ao largo do fato que as guerras representam cicatrizes na memória coletiva e privilegia-se uma narrativa baseada no relato dos que estiveram presentes. A esse respeito, é relevante a associação entre o individual e o coletivo no trecho citado abaixo:

nossas lembranças são coletivas; recordamos em função do(s) outro(s), mesmo quando se trata de eventos que presenciamos sozinhos e objetos que vislumbramos sem testemunhas. Isso ocorre, (...), porque nunca estamos sozinhos: 'carregamos conosco uma quantidade de pessoas que não se misturam" (OLIVEIRA; ORRICO, 2005, p. 82-83).

Por mais que a maior parte do público consumidor atual não tenha vivido diretamente as agruras da Primeira Guerra Mundial, os conflitos, com toda a sua carga negativa, estão impregnados na memória coletiva e fazem parte do modo como cada um se relaciona com a memória social:

A articulação entre memória individual e memória coletiva é racional; trata-se de uma operação de inteligência. Por meio dessa faculdade, localizamos uma lembrança e a ligamos a uma imagem e/ou a um lugar ou acontecimento. Finalmente, a memória individual é social porque: a) seu trabalho é intelectual - para localizar nossas lembranças fazemos uso de nossa inteligência presente, aquela que depende de nossa sociedade; b) a rememoração parte do presente (experiência exterior, social) para o passado (experiência interna, individual); e c) as lembranças são compartilhadas - estão relacionadas a um conjunto de lembranças comuns

6 Para um breve exemplo, vide Fogg (2014). 
ao(s) grupo(s) do qual fazermos, fizemos ou faremos parte. (OLIVEIRA; ORRICO, 2005, p. 83)

Mais comumente, pensar em guerra é pensar no horror do sofrimento desumano e na morte. No afã de prender a atenção e se tornar relevante, esta superprodução dialoga com o centenário e ao mesmo tempo foge ao lugar comum. Surpreende e emociona o público ao focalizar cenas da mais épica humanidade com uma mensagem positiva atrelada ao espírito das festividades natalinas que marcam, de forma contundente, o calendário de vendas do varejo.

De olho no faturamento, é evidente o estímulo ao consumo simbólico associado a esta companha, que promove a venda, ao preço de uma libra esterlina ${ }^{7}$, da barra de chocolate mostrada no filme. Segundo se informa, a renda seria revertida para a Legião de excombatentes, que já teria mais de vinte anos de parceria com esta cadeia de supermercados.

Novamente se apresenta a importância do objeto físico como elemento tangível de memória. Tem-se aqui o consumo material que prolonga o consumo simbólico, ambos indissociáveis. Segundo esta campanha, o espírito natalino toma forma no gesto de compartilhar. Lados opostos compartilharam o improvável momento do cessarfogo, fez-se uma pausa temporária e não oficial da beligerância para a descontração e o congraçamento, com futebol e chocolate, no Natal de 1914.

Figura 2: Chocolate nas trincheiras

7 Valor que corresponde, aproximadamente, a pouco mais de $\mathrm{R} \$ 4,00$. 


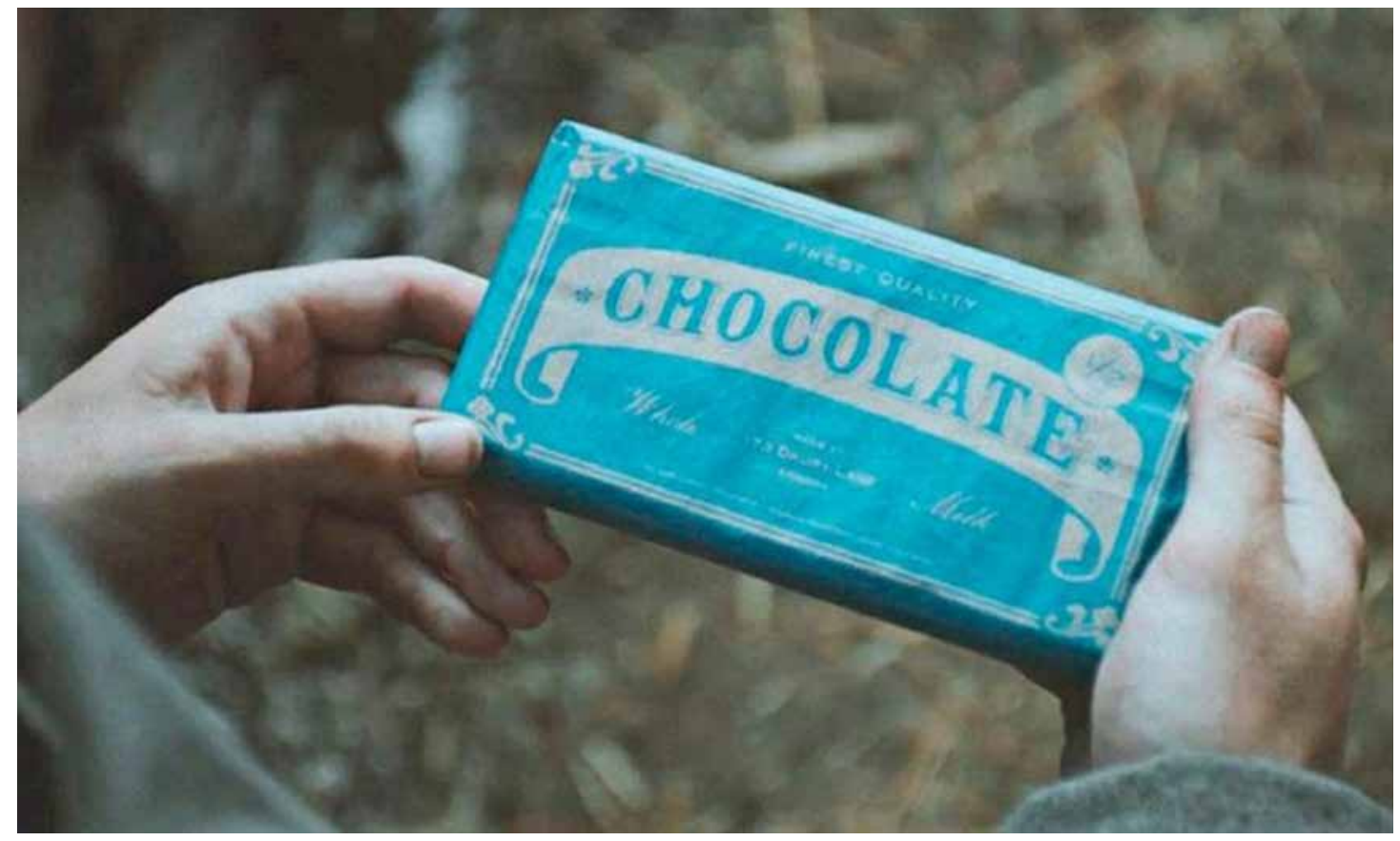

Fonte: www.theguardian.com

Como era de se esperar, o comercial carrega nas tintas ao, ostensivamente, tomar o partido dos soldados britânicos, creditandoIhes não apenas a iniciativa daquela ousadia, como também o gol da vitória e a grandeza do altruísmo. No enlevo do patriotismo e do espírito do Natal, a população britânica é convocada a compartilhar também, adquirindo a emblemática barra de chocolate, doando para a Legião e fazendo suas compras habitualmente neste supermercado.

\section{Palácios da memória}

Ambas as campanhas examinadas neste artigo tomam a memória de fatos ocorridos durante a Primeira Guerra Mundial como ponto de partida para atingirem seus objetivos.

Desde Platão, em que o esforço de rememoração se confunde com a tarefa de buscar a verdade, passando pelas abordagens de Santo Agostinho em seu processo de conhecimento de si para atingir a Deus e a verdade por meio da exploração do 'palácio da memória', e Montaigne e a valorização do esquecimento como dispositivo para o ato criativo, a memória tem tido o foco direcionado sobretudo para o processo individual de rememoração. Trata-se de um fenômeno pensado primordialmente na relação do sujeito com o seu passado ou como processo que, na continuidade, possibilita condições de aprendizado e crescimento (OLIVEIRA; ORRICO, 
2005, p. 81-82).

Como já mencionado anteriormente, este é um período histórico carregado de afetividade e que mobiliza a sociedade de forma veemente, motivo pelo qual o filme da campanha do Sainsbury's em seu canal no YouTube é complementado por dois outros audiovisuais: um sobre os bastidores da produção da campanha e outro sobre a história que a norteou. Parece importante reforçar o respeito à memória coletiva por meio destes complementos, para justificar a peça publicitária. Desse modo, espera-se lograr o objetivo de atrelar, à imagem do supermercado, a ideia de empresa socialmente responsável.

No filme que narra os bastidores do comercial $^{8}$, informa-se que, até dezembro de 1914, a Guerra já durava quase cinco meses e havia dizimado perto de um milhão de vidas. Cartas e diários da Frente Ocidental descrevem como as armas foram silenciadas na véspera de Natal daquele ano. Enquanto se ouve o depoimento do neto de um veterano, em cujo diário a câmera focaliza a página datada do dia de Natal de 1914, pode-se ler a anotação: "um dia único na história do mundo".

Com base no entendimento dos britânicos a respeito do Natal, como uma data marcada por encontros com a família e amigos, desenvolveu-se a campanha publicitária a partir do argumento central "Christmas is for sharing"." De certa forma, ao trazer à tona recordações em gôndolas recheadas de chocolates que remetem à Primeira Guerra Mundial, parece-nos que o supermercado pretendeu adquirir o status, ao menos temporário, de palácio da memória.

Voltando nossa atenção para a campanha da inauguração das novas galerias no IWM, vê-se que, por meio da somatória desses relatos em diários, cartas, depoimentos e objetos pessoais os mais variados, ajuda-se a reconstruir fragmentos da memória pública e a mantê-la viva de modo a esconjurar o fantasma do apagamento da História pelo

\footnotetext{
8 Disponível em: https://www.youtube.com/watch?v=2s1YvnfcFVs\&feature=iv\&src vid=NWF2JBb1bvM\&annotation_id=annotation_148824475. Último acesso em: 15/08/2016.

9 "O Natal é tempo de compartilhar", em tradução livre.
} 
esquecimento. Aqui, a relevância da memória coletiva na manutenção dos vínculos sociais:

A relevância dos estudos que têm a memória como foco é potencializada pela (...) compulsão memorial que afeta as sociedades modernas (...). (...) Por essa compulsão, podemos entender também um medo do esquecimento, que se relaciona à importância da memória para a manutenção do sujeito social. (OLIVEIRA; ORRICO, 2005, p. 84)

Em um museu, trabalha-se nesta lógica de acúmulo de informações que perpetuam a memória, não apenas pelo medo do esquecimento, mas também com o propósito de preservar e educar para o futuro.

De volta ao outro comercial mencionado acima, há indícios, nos depoimentos recolhidos, indicando que o episódio na noite de Natal, no início da Grande Guerra, teria marcado o início do entrelaçamento de histórias entre soldados aliados e inimigos, ressaltando a coragem dos que se arriscaram para viver este momento. Os relatos sugerem que esta cena teria se repetido ao longo da uma vasta extensão de trincheiras.

Figura 3: Joyeux Noël, o filme

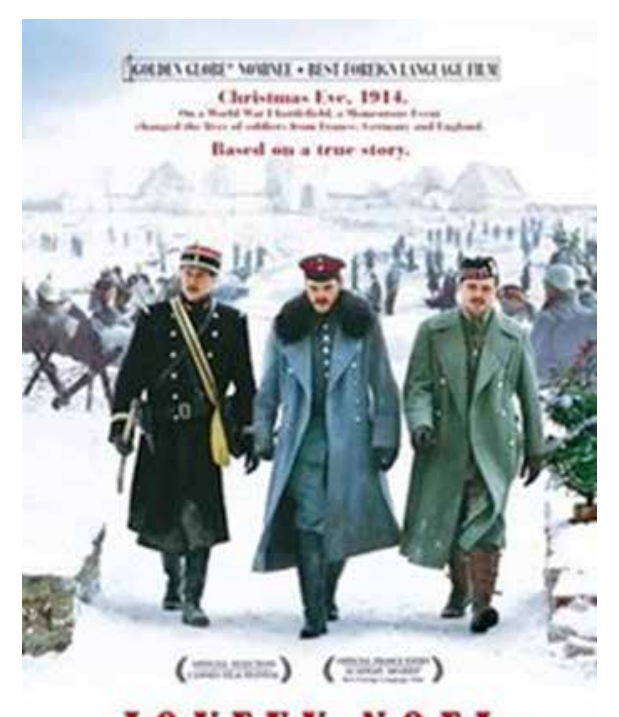

\section{J O Y E UX N O E L}

Fonte: en.wikipedia.org

Em Joyeux Noël, longa-metragem dirigido e roteirizado por 
Christian Carion, com base em depoimentos históricos, a narrativa sobre a trégua nas trincheiras do primeiro conflito de proporções mundiais ganha contornos ainda mais dramáticos com a denúncia de que seus protagonistas teriam sido duramente punidos por oficiais superiores, indignados com o que foi considerado como uma insubordinação das tropas. Nesta coprodução entre França, Alemanha, Bélgica, Romênia e Reino Unido, de 2005, que ganhou o Oscar de melhor filme estrangeiro, o episódio congrega oficiais e soldados franceses, escoceses e alemães.

Evidentemente, não se pode ter cem por cento de certeza de que mesmo nos tempos mais duros, no auge da mais trágica série de batalhas até então vividas, a grandeza da humanidade teria se desenrolado como nas cenas retratadas. "A memória que temos de um evento nunca pode ser a total recuperação do mesmo, tal como tenha ocorrido, pois a memória não é estática, uma vez que está sempre trabalhando sobre estimativas e alterando o passado" (FERREIRA, 1995 , p. 2). Jerusa Pires Ferreira segue seu pensamento sobre o caráter fragmentário da memória e sua relação com o tempo ao dizer que

\footnotetext{
há nas pessoas todo um desejo de guardar e recuperar o que se extravia na vertigem. Mas a memória disso ou daquilo pode ser exercida em plenitude ou em suas incompletudes, recriações e até impedimentos. Assim há também memória como sustentação de identidades, rede de conhecimentos que se projetam ao passado e ao futuro concomitantemente (FERREIRA, 2001, p. 11).
}

Para avaliar a fragmentação do todo e a relevância da questão do ponto de vista ao recontar este episódio histórico, também podemos levar em conta o que diz Ecléa Bosi em obra de referência:

A lembrança é uma imagem construída pelos materiais que estão, agora, à nossa disposição, no conjunto de representações que povoam nossa consciência atual. (...) O simples fato de lembrar o passado, no presente, exclui a identidade entre as imagens de um e de outro, e propõe a sua diferença em termos de ponto de vista (BOSI, 1994, p. 55 , grifos no original).

Ao rememorar, no presente, os fatos do passado, tanto o filme quanto os comerciais aqui enfocados fornecem oportunidades para que o grande público possa perceber o lado humano que vai além e que 
ocorre apesar da destruição da uma Guerra Mundial. São pequenos gestos da vida cotidiana, breves momentos de solidariedade e convívio em meio às agruras da contenda, fragmentos de relatos cuidadosamente recolhidos e ficcionalizados nas duas narrativas publicitárias em questão.

\section{Papoulas}

Na reconstituição deste marco histórico pela publicidade, destacase a relevância da Legião Real Britânica (The Royal British Legion $T R B L$ ), entidade que promove a Centenary Poppy Campaign, para manter viva a memória da Guerra e arrecadar fundos para as famílias dos veteranos. Nesta iniciativa que usa a singela figura da papoula como símbolo ${ }^{10}$, estimula-se as cidades e os cidadãos a plantarem sementes de papoula por todo o território britânico, em homenagem aos combatentes mortos na Primeira Guerra Mundial.

Notamos a presença da papoula também nas ilustrações que retratam os campos de batalha, no filme de animação do IWM. No ano do centenário, milhões de visitantes foram à Torre de Londres para ver a instalação Blood Swept Lands and Seas of Red ${ }^{11}$, cujo título remete a um poema de soldado desconhecido. De modo progressivo, durante o período de julho a novembro de 2014 , um total de 888.246 papoulas $^{12}$ de cerâmica lotaram o fosso, em memória a cada militar britânico, ou das suas colônias, que tombou na Primeira Guerra Mundial. O local foi escolhido pelo fato da Torre de Londres ter sido usada, em 1914, como local de recrutamento e adestramento de voluntários, assim como também serviu de prisão e praça de execução de espiões capturados durante a Guerra.

\footnotetext{
10 Disponível em: http://www.britishlegion.org.uk/remembrance/ww1-centenary/centenary-poppycampaign. Último acesso em: 30/08/2016.

11 Em tradução livre: "Terras varridas com sangue e rubros mares", verso inicial de poema escrito por soldado anônimo morto na Primeira Grande Guerra.

12 É interessante notar que cada uma destas papoulas foi vendida após o desmonte da instalação, tendo sido a quantia arrecadada revertida em doações para as entidades de veteranos. Informações disponíveis em: http://www.hrp.org.uk/tower-of-Iondon/history-and-stories/tower-of-london-remembers/\#gs. OfOR76w Último acesso em: 31/08/2016.
} 


\section{Contracampo}

Figura 4: Papoulas da lembrança na Torre de Londres

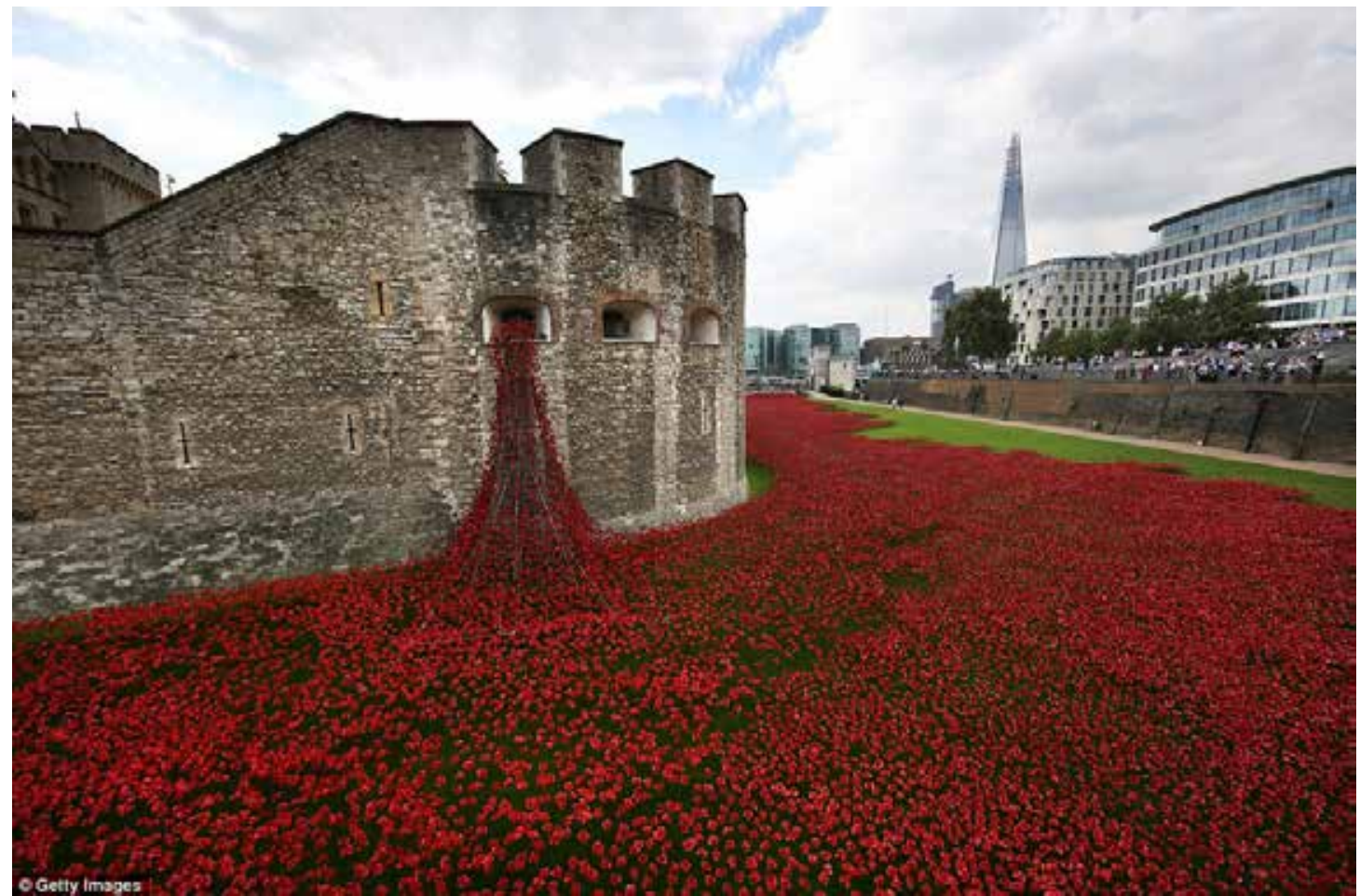

Fonte: www.dailymail.co.uk

A papoula tornou-se símbolo das lembranças deste conflito por conta desta singela flor ser muito presente nos campos de batalha, especialmente na Frente Ocidental. Ela inspirou o célebre poema In Flanders Fields ${ }^{13}$, escrito pelo médico canadense e oficial da artilharia, John McCrae, após enterrar um soldado de seu regimento. Com um broche em forma de papoula na lapela, autoridades e veteranos prestaram tributo às vítimas nas inúmeras cerimônias oficiais que marcaram o centenário.

Oferecer uma homenagem a cada um dos 8 milhões que serviram na Grande Guerra é a ambição do projeto Lives of the First World $W r^{14}$, uma iniciativa da TRBL que se assemelha ao memorial online estabelecido pelo Imperial War Museum. Nestes projetos em andamento, são recolhidas e catalogadas imagens e informações sobre cada homem ou mulher britânicos e membros das colônias que serviram na Grande Guerra.

13 Disponível em: http://www.greatwar.co.uk/poems/john-mccrae-in-flanders-fields.htm Último acesso em; 31/08/2016.

14 Em tradução livre "Vidas da Primeira Guerra Mundial". Página oficial disponível online em: https:// livesofthefirstworldwar.org/ Último acesso em: 30/08/2016. 
Entende-se que a associação entre a Legião e a rede de supermercados na campanha de Natal sobre a qual tratamos neste artigo traria benefícios para ambos os lados, representando para o Sainsbury's o endosso moral que eventualmente atenuaria o caráter comercial do recurso à memória coletiva deste marco histórico.

No tipo de publicidade que caracteriza as campanhas natalinas da marca, as lógicas do consumo são como que subsumidas pelas dinâmicas do entretenimento. Desse modo, a cada ano, oferece-se ao espectador deslumbrantes superproduções nos moldes cinematográficos e de forte apelo emocional, que carregam mensagens edificantes. Mais do que anunciar produtos e serviços, o objetivo estratégico deste tipo de storytelling seria fidelizar o consumidor, ao promover uma vinculação afetiva com o universo da marca. A narrativa açucarada serve como recurso para tornar tangível o ethos corporativo com o qual, esperase, o público possa se identificar. Conforme reflexão desenvolvida em trabalho anterior (CASTRO 2014, p. 66), valoriza-se sobremaneira a vinculação afetiva entre consumidores e marcas:

Do cliente ao fã, do comprador ao colecionador aficionado, do consumidor ao colaborador, do endossante ao divulgador: o competitivo ambiente de negócios enseja forte investimento por parte das corporações na construção afetiva do universo simbólico da marca.

\section{Entretenimento, consumo e a memória social}

Nestes tempos de acesso, aparentemente ilimitado, a conteúdos de todos os tipos nas redes telemáticas da comunicação digital, importa ressaltar a diferença entre memória e arquivo. Diferentemente do arquivo, que a tudo armazena de modo diligente e indiscriminado, o trabalho da memória é matizado pela carga afetiva atrelada a lembranças, recordações, lapsos e esquecimentos. O viés eminentemente afetivo da memória se faz presente, tanto em nível social, quanto individual.

Maria Cristina Franco Ferraz (2010) aborda a ancoragem corporal da memória e remete aos estudos do neurocientista Iván Izquierdo para explicar que a memória libera hormônios no cérebro, deflagrando 
sentimentos e operando na produção de sentidos. Temos aí a ideia de um cérebro funcional como mediador entre as lembranças que se atualizam e a totalidade da memória, suspensa na virtualidade. Nesse sentido, longe de ser local de armazenamento ou arquivo de lembranças, o cérebro pode ser associado à inibição das lembranças, ao esquecimento (FERRAZ, 2010, p. 77) que, como foi dito, desempenha um papel ativo na manutenção do equilíbrio do sistema. Segundo Izquierdo (2006, p. 290), "os mecanismos da memória se saturam". Para o autor:

De fato, é necessário esquecer, ou pelo menos manter longe da evocação muitas memórias. Há muitas que nos perturbam (...). Há outras que nos prejudicam (...) ou nos perseguem (...). Em razão do problema da saturação, existem memórias que impedem de adquirir outras novas ou adquirir outras antigas, mais importantes. (IZQUIERDO, 2006, p. 290)

Por sua vez, Ulpiano Bezerra de Meneses (2007, p. 18) pondera que "o cérebro não trabalha com informação, mas com significados". Nesta perspectiva, o corpo todo está a serviço da percepção das memórias e experimentando sensações e emoções. Porém, como discutimos acima, o individual é sempre profundamente matizado pelo social. Embora sejam modulados pela experiência pessoal, os significados são atribuídos socialmente. Assim sendo, os complexos mecanismos de produção de sentidos ensejam, por vezes, renhidas disputas entre instâncias individuais e sociais, bem como entre atores diversos presentes em nossa cultura midiática.

É importante ressaltar a estreita associação entre mídia e consumo. Emissoras públicas e privadas mantêm-se atentas aos índices de audiência. Enquanto para as últimas, a intenção é tornar financeiramente lucrativo o tempo ou o espaço vendido para a publicidade, para as primeiras, trata-se da sempre delicada questão da relevância social do investimento público nos meios de comunicação em tempos neoliberais. Mesmo em uma sociedade na qual o ideário da comunicação pública ensejou a criação da BBC, nos anos 1920, mudanças de conjuntura ocasionam o desinvestimento e a redução de seu tamanho e alcance. Para não cair no ostracismo, investe-se 
em programações pautadas nas dinâmicas do entretenimento, com o objetivo principal de atrair grandes audiências.

É justamente em virtude do espraiamento das lógicas de consumo, pelas mais diversas esferas da vida social, que a memória, como patrimônio cultural de uma dada sociedade, corre o risco de ser banalizada no jorro incansável de imagens e narrativas feitas para comover e promover produtos, serviços, marcas e corporações.

Como fruto desta lógica, que demonstra predileção por diluir a complexidade da vida nas dinâmicas do entretenimento, o deslocamento da noção de cultura como patrimônio em direção aos interesses de ordem comercial transformaria museus em parques temáticos e supermercados em operadores da memória social.

\section{Referências}

BEIGUELMAN, Giselle. Reinventar a memória é preciso. In: BEIGUELMAN, Giselle; MAGALHÃES, Ana G. (Org.). Futuros possíveis: arte, museus e arquivos digitais $=$ Possible futures: art, museums and digital archives. São Paulo: Petrópolis, Edusp, 2014, p. 12 - 33.

BOSI, Ecléa. Memória e sociedade: lembranças de velhos. $3^{a}$ ed., São Paulo: Cia. das Letras, 1994.

CASTRO, Gisela G. S. Comunicação e consumo nas dinâmicas culturais do mundo globalizado. Pragmatizes - Revista Latino-Americana de Estudos em Cultura, no. 6, 2014, p. $58-71$.

COSTA, Maria Cristina C.. O objeto, o colecionador e o museu. Revista Imaginário. Memória. No 2. São Paulo, USP, jan/1995.

DESVALLÉES, André; MAIRESSE, François. Conceitos-chave de museologia. São Paulo: Comitê Brasileiro do Conselho Internacional de Museus, Conselho Internacional de Museus, Pinacoteca do Estado de São Paulo, Secretaria de Estado da Cultura, 2013.

FERRAZ, Maria Cristina F.. Homo deletabilis: corpo, percepção, esquecimento do século XIX ao XXI. Rio de Janeiro: Garamond, 2010.

FERREIRA, Jerusa P.. De magia, tempo e memória. Revista Imaginário. Memória. No. 2. São Paulo, USP, jan/1995.

Apresentação. In: NUNES, Mônica R. F. A memória na mídia:

a evolução dos memes de afeto. São Paulo: Annablume, FAPESP, 2001.

FOGG, Ally. Sainsbury's Christmas ad is a dangerous and disrespectful 
masterpiece. The Guardian, Opinion, 13/11/2014.

GARCÍA CANCLINI, Néstor. Consumidores e cidadãos. Rio de Janeiro: Editora UFRJ, 2010.

IZQUERDO, Iván; BEVILAQUA, Lia R. M.; CAMMAROTA, Martin. A arte de esquecer. Estudos Avançados, vol. 20, no. 58, 2006, p. 289 - 296.

KENNEDY, Maev. Aardman animates notes from frontline for Imperial War Museum reopening. The Guardian, First World War, 07/07/2014.

MENESES, Ulpiano B. de. Os paradoxos da memória. In: MIRANDA, Danilo Santos de (org.). Memória e cultura: a importância da memória na formação cultural humana. São Paulo: Ed. SESC SP, 2007.

OLIVEIRA, Carmen Irene C. de; ORRICO, Evelyn G. D.. Memória e discurso: um diálogo promissor. In: GONDAR, Jô; DODEBEI, Vera (Orgs.) O que é memória social? Rio de Janeiro: Contra Capa Livraria, Programa de PósGraduação em Memória Social da Universidade Federal do Estado do Rio de Janeiro, 2005.

PASQUALIN, Vera da Cunha. Práticas culturais e as políticas governamentais: um olhar sobre o vale-cultura. In: JORDÃO, Gisele; ALLUCCI, Renata R.. Panorama setorial da cultura brasileira 2013-2014. São Paulo: Allucci \& Associados Comunicações, 2014.

SMITH, Mark. Sainsbury's Christmas advert recreates first world war truce. The Guardian. Advertising. 13/11/2014. 


\section{"O QUUE VOCÊ FAZ PARA SER FELIZ?": REFLEXÕES SOBRE A FELICIDADE E A MEMÓRIA NO DISCURSO PUBLICITÁRIO}

\section{"WHAT DO YOU DO TO BE HAPPY?": REFLECTIONS ON HAPPINESS AND MEMORY IN ADVERTISING DISCOURSE}

\section{VICTOR MÁRCIO LAUS REIS GOMES}

Doutor em Comunicação Social. Professor e pesquisador do Programa de PósGraduação em Comunicação da Universidade Católica de Brasília. Brasil. victorlaus@gmail.com

\section{RENATA ANDREONI}

Doutoranda e Mestre em Comunicação Social pela Pontifícia Universidade Católica do Rio Grande do Sul (PUCRS). Brasil.

andreoni.renata@gmail.com

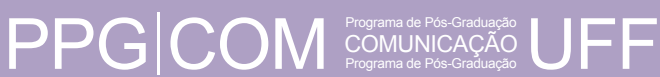

AO CITAR ESTE ARTIGO, UTILIZE A SEGUINTE REFERÊNCIA:

GOMES, Victor Márcio Laus Reis; ANDREONI, Renata. "O que você faz para ser feliz?": reflexões sobre a felicidade e a memória no discurso publicitário. Contracampo, Niterói, v. 35, n. 03, dez. 2016/ mar. 2017.

Enviado em 10 de setembro de 2015 / Aceito em: 09 de março de 2016. 


\section{Resumo}

Este trabalho apresenta um olhar reflexivo sobre o discurso publicitário. Mais especificamente, são explorados os sentidos construídos em torno da felicidade e o lugar da memória no discurso de uma campanha veiculada pela rede de supermercados Pão de Açúcar em 2013. A reflexão é conduzida através da Análise de Discurso, de acordo com os pressupostos de Patrick Charaudeau, e indica que os discursos publicitários podem ter relações com uma base de memórias sociais que despertam cadeias de identificações nos sujeitos consumidores. O estudo ainda explora possibilidades de compreensão de perspectivas conceituais da memória associadas aos processos de comunicação.

Palavras-chave

Discurso; Publicidade; Memória

\section{Abstract}

This paper presents a reflection on the advertising discourse. More specifically, it explores the meaning built around happiness and the place of memory in a campaign discourse from the supermarket chain Pão de Açúcar. The discussion is conducted through Discourse Analysis, according to Patrick Charaudeau assumptions, and it indicates that advertising discourses may be related to a base of social memories which may build identification chains in consumers. The study also explores possibilities of conceptual perspectives on memory associated with the communication processes.

\section{Keywords}

Discourse; Advertising; Memory. 
No presente trabalho propomos uma reflexão sobre o discurso publicitário da marca Pão de Açúcar. Para tanto, trabalhamos com a Análise de Discurso (AD), a partir dos pressupostos de Charaudeau (1997; 2001; 2006; 2010). O corpus de nosso estudo é constituído por um filme veiculado pela rede de supermercados Pão de Açúcar, que tem como mote a felicidade. O material analisado foi produzido e veiculado em 2013 e teve como protagonista a cantora e atriz Clarice Falcão. A campanha em questão baseia-se em aspectos conceituais, deslocando-se das características varejistas. A postura pode ser facilmente identificada no próprio conceito explorado em seu slogan "O que faz você feliz", utilizado desde 2007 (SANTOS, 2013).

Compreendemos a publicidade do Pão de Açúcar como um ato de linguagem, constituído sobre um jogo aberto de relações, variável, em dimensões explícitas e implícitas. Essa abordagem de análise possibilita, conforme Castro (2002), refletir sobre os seus lugares de pertinência. A saber: lugar das condições de produção; lugar das condições de reconhecimento; e lugar de constituição do discurso. É sobre essa organicidade que estruturaremos este trabalho, buscando problematizar as potencialidades da memória no processo comunicacional, ou seja, como a memória pode atuar e (re)significar discursos publicitários.

Nosso objetivo é compreender as estratégias discursivas e os sentidos construídos em torno da felicidade, além de refletir sobre o lugar da memória nesse discurso. A seguir, tecemos algumas considerações sobre o discurso publicitário e sua relação com a felicidade na realidade social contemporânea. Compreendemos este cenário como o lugar das condições de reconhecimento do nosso objeto de análise. Posteriormente, apresentamos as condições de produção e a análise do discurso, refletindo sobre suas possíveis relações com a memória.

\section{Perspectivas sociais - o lugar das condições de reconhecimento}

Consideramos que o discurso publicitário é um espaço ideal para provocar e despertar emoções e sensações com o intuito de 
criar desejos e necessidades sobre os sujeitos espectadores. Essa relação, na contemporaneidade, pode ser contextualizada a partir das características que concernem os pensamentos ${ }^{1}$ da pós-modernidade (MAFFESOLI, 2007) e da Hipermodernidade (LIPOVETSKY, 2007). Ao refletir sobre as especificidades e relações da realidade social na atualidade, esses autores enfatizam que os princípios que orientavam a modernidade, como racionalidade, materialidade, ordem e progresso, foram substituídos por aspectos lúdicos, oníricos, intangíveis, relacionados ao prazer, aos afetos, ao gozo e à fruição. Destacam, ainda, que a esperança, como força motriz sobre um horizonte de expectativas no futuro, não encontra mais eco social, pois vivemos, agora, sobre um constante presenteísmo. Conforme indica Maffesoli (2012), a temporalidade dos modernos é o futuro, baseada no mito do progresso, enquanto a temporalidade pós-moderna é o presente.

Nessa perspectiva, Maffesoli (2012) indica que passamos da ordem da representação à apresentação, na qual não criamos necessidades, mas respondemos expectativas que emergem da/ na vida cotidiana. As características - estruturante, racionalizante e hermética - da modernidade dão lugar às formas orgânicas, às múltiplas identificações, às emoções que vão tecendo uma "razão sensível", na efervescência das socialidades que se (re/des)constituem nas relações e interações prosaicas. Esse olhar sobre a realidade social nos apresenta novas dimensões para refletirmos os atos de linguagem e seus "lugares de pertinência" (CASTRO, 2002). Entre a fluidez, a volatilidade e a efervescência, o hedonismo vai configurando nossas relações individuais e coletivas, na formação de pactos sociais. Nesse cenário, Maffesoli (2003, p. 12) destaca a personagem mitológica Dionísio (representante das atividades prazerosas) que propaga a "[...]

1 Estas definições sobre a sociedade contemporânea, embora compartilhem de características comuns, não se resumem apenas a uma nomenclatura distinta, são elaboradas e apresentadas com nuances e perspectivas singulares, desenvolvidas de acordo com a postura de cada teórico. Nossa intenção, neste momento, não é explorar as concepções de cada autor, refletindo sobre suas análises dissonantes. Nesse sentido, ancoramos nossas concepções sobre o cenário (lugar das condições de reconhecimento) a partir das proposições de ambos, no sentido em que apresentam novas dimensões e configurações sociais, indicando a emergência de novas formas de relacionamentos, apreensões, identificações e experiências; no hedonismo e na força de grupos de pertencimento. 
importância do festivo, a potência da natureza e do entorno, o jogo das aparências, o retorno do cíclico acentuando o destino, coisas que fazem da existência uma sucessão de instantes eternos". Hoff (2015) enfatiza que no capitalismo atual muito se produz de individuação, de múltiplas e/ou fluídicas identidades nas convocações midiáticas para o consumo.

De acordo com os contributos de Lipovetsky e Serroy (2015, p. 223)，

[...] a nova cena publicitária é inseparável da ampla difusão da nova cultura individualista (hedonismo, contracultura, neofeminismo, liberdade sexual, autonomia dos sujeitos), que trabalhou para privilegiar a originalidade, o divertimento, o humor, mas também as atmosferas emocionais que dão aos espectadores a sensação de não serem comandados de fora, de serem capazes de decifrar os códigos, de compreender sugestões e piscar de olhos, de serem livres e adultos. Menos "lições" dadas, mais convites à viagem e ao sentir: esse movimento é sustentado pelo surto da individualização dos comportamentos e da cultura.

Gilles Lipovetsky, filósofo francês, teórico da Hipermodernidade, aborda a felicidade como uma das temáticas centrais de seu pensamento, indicando o surgimento de novas formas de consumo atreladas a emoções, a sensações e a experiências. Em sua obra "A felicidade paradoxal: ensaio sobre a sociedade de hiperconsumo", 0 autor considera que vivemos em uma espécie de império do consumo de "[...] necessidades orquestradas por uma lógica desinstitucionalizada, subjetiva, emocional" (LIPOVETSKY, 2007, p. 41).

No contexto contemporâneo, a grande mídia parece ter uma contribuição definitiva para a difusão, legitimação e até, utilizando as palavras de Freire Filho (2010), para o constrangimento e incitação para a adesão a ideias e padrões de comportamento que são amplamente aceitos e tidos como "verdades" quase absolutas. Conforme o autor, as campanhas publicitárias, através de slogans, imagens e textos, trazem incentivos, recomendações e receitas rápidas de felicidade, contribuindo para que o tema, a busca permanente da felicidade, não seja esquecido em nenhum momento. Parecem funcionar como lembretes. 
Sob esse imaginário, destacamos uma perspectiva de mercado baseada na intangibilidade evocada pela publicidade, em uma natureza simbólica de exaltação de valores sensitivos. Dessa forma, o simbolismo destaca-se em relação à objetividade do produto, quando o discurso publicitário substitui seu enfoque sobre a funcionalidade e eficácia por representações de experiências afetivas, imaginárias e sensoriais. De acordo com Lipovetsky, podemos perceber os possíveis sujeitos receptores (sujeitos em relação) da publicidade contemporânea como hiperconsumidores, que não se concentram tão somente sobre o bem-estar material, pois constroem suas subjetividades em torno de desenvolvimento pessoal, psíquico, emocional. Portanto,

\begin{abstract}
O materialismo da primeira sociedade de consumo passou de moda: assistimos à expansão do mercado da alma e de sua transformação, do equilíbrio e da autoestima, enquanto proliferam as farmácias da felicidade. Numa época em que o sofrimento é desprovido de todo sentido, em que os grandes referenciais tradicionais e históricos estão esgotados, a questão da felicidade interior "volta à tona", tornandose um segmento comercial, um objeto de marketing que o hiperconsumidor quer poder ter em mãos, sem esforço, imediatamente e por todos os meios (LIPOVETSKY, 2004, p. 15 , grifo nosso).
\end{abstract}

É a partir dessa apreensão sobre a apropriação da felicidade pelo discurso publicitário que a identificamos como argumento verbal, sensitivo, iconográfico e simbólico de um discurso carregado de elementos sedutores e emotivos, reunidos em um esforço de cooptação. O tema da felicidade é incorporado como estratégia de captação/ sensibilização dos públicos, na aposta de gerar identificação.

Onde se encontra a felicidade? Ela possui uma territorialidade? Uma temporalidade? Qual a sua natureza? Dogmática? Prosaica? Utópica? Econômica? Cultural? Podemos pensar sobre a procura da felicidade, seu locus. Há respostas para todas essas perguntas? Acreditamos que, possivelmente, tais questões possam ser variantes de uma discussão filosófica que não enfatizaremos neste texto. A intenção com esses questionamentos justifica-se no sentido de evidenciarmos a complexidade dessa temática. Nosso enfoque, ao 
destacar essa dimensão enigmática sobre a felicidade, é sublinhar a postura controversa da publicidade contemporânea de (des)construir um discurso em seu entorno, baseado na simplicidade e na inocência. Princípios, esses, constituídos sob um universo de estereótipos.

A partir dessas considerações sobre a realidade social contemporânea e sobre a (re)significação da felicidade, buscamos apresentar o lugar das condições de reconhecimento do discurso publicitário do Pão de Açúcar. Ou seja, o contexto em que o processo de assimilação e retenção do público consumidor encontra-se para a compreensão da mensagem. Para a continuidade da reflexão, dissertaremos a seguir sobre o lugar das condições de produção, abordando princípios que orientam a formatação, a atuação e o projeto da instituição em questão: o Grupo Pão de Açúcar (GPA).

\section{Grupo Pão de Açúcar - considerações sobre as condições de produção}

Pão de Açúcar é o nome popular da Companhia Brasileira de Distribuição ( $C B D$ ) controlada pelo Grupo Casino, de capital francês. A marca Pão de Açúcar teve a sua origem na fundação de uma doceria, estabelecida em 1948, no Rio de Janeiro, por Valentim Diniz. A primeira loja dos Supermercados Pão de Açúcar foi aberta em 1959. Uma empresa familiar que alcançou, nos anos 70 e 80, o lugar de maior rede varejista do Brasil, buscando sua internacionalização, a partir de Portugal e Angola, no final da década de 1960. Entretanto, o Grupo também passou por inúmeras crises geradas por uma multiplicidade de fatores, que, depois de muitas reestruturações, levaram à abertura de seu capital em Bolsas de Valores nacionais e internacionais, no final dos anos 90. Sua associação ao Grupo Casino ocorreu em 1999. A incorporação à rede francesa permitiu ao Pão de Açúcar um novo processo de expansão. No entanto, sobre outras configurações administrativas, não mais como uma empresa familiar (COSTA, 2004).

O GPA é, no momento da realização deste estudo, a maior rede varejista do Brasil, possuindo mais de 2.100 pontos de venda e mais 
de 151 mil funcionários. Em 2014, o grupo inaugurou 212 lojas e, em 2015, previa investimentos de mais de 1,5 bilhões de reais (GRUPO PÃO DE AÇUCAR, 2015). Essas informações indicam uma atuação em franca expansão. Sobre esse aspecto, destacamos a importância de ações na fidelização e ampliação do público. Dessa forma, o discurso publicitário assume um papel estratégico nesse processo. Ainda de acordo com o site institucional da empresa,

\begin{abstract}
A marca tem como característica oferecer sortimento diferenciado de produtos e serviços como consultores de vinhos e queijos, além de ser referência em inovação, saudabilidade e sustentabilidade. Em linha com a atitude de vanguarda do Grupo, o Pão de Açúcar lançou, em 1995, a primeira loja de comércio eletrônico de alimentos do país: o Pão de Açúcar Delivery. Também foi pioneiro ao criar um programa de relacionamento, o Pão de Açúcar Mais, em 2000; e ao apresentar o modelo de loja verde, em 2008. A marca também é reconhecida pelo consumidor por incentivar a prática do consumo consciente e um estilo de vida saudável (GRUPO PÃO DE AÇUCAR, 2015).
\end{abstract}

Em matéria da Revista Exame, veiculada em 15/03/2013, podemos conferir que o Pão de Açúcar lançou uma nova questão: "O que você faz para ser feliz?" Um questionamento que passa a ser a assinatura da sua campanha institucional do ano: "Ser feliz é só começar". O conceito foi elaborado pela agência de publicidade do Grupo, desenvolvendo a temática da felicidade proposta em 2007.

A ideia era criar uma comunicação emocional com o público e abordar questões simples da vida. A utilização da temática foi inclusa também na promessa de marca da loja: "lugar de gente feliz". Observa-se que toda a comunicação do supermercado foi reformulada para se adequar à temática (SANTOS, 2013, p. 87).

O filme, em análise neste texto, tem como protagonista Clarice Falcão. Cantora e atriz que ficou conhecida, pelo grande público, por suas participações no programa humorístico Porta dos Fundos, veiculado na internet. Além disso, Clarice possui um canal próprio no Youtube onde apresenta seus trabalhos. A cantora é ícone de um estilo musical baseado na simplicidade, inspirado no estilo norte-americano 
da música indie-folk. Sua imagem está associada a essa simplicidade, quase angelical, e à juventude.

O enfoque desse discurso, protagonizado por Clarice Falcão, incita os indivíduos a serem agentes de mudança, em buscar aquilo que Ihes traz felicidade. O Pão de Açúcar, como proponente desse discurso, coloca-se no centro desse processo, sendo um lugar² de experiências, para além da materialidade de seus produtos.

\section{A análise - o lugar de constituição do discurso e seus sujeitos}

Conforme Castro (2002), o lugar de constituição do discurso e seus sujeitos é o espaço em que se configura o produto discursivo, como resultado da relação de co-intencionalidade entre os parceiros, sobre formas verbais e não verbais. Nesse sentido, ancoramos a nossa análise nos pressupostos que compreendem a concepção de ato de linguagem, a partir do contrato de comunicação, desenvolvido por Charaudeau.

Charaudeau (2001) define duas designações para caracterizar os dois principais sujeitos de um ato enunciativo. A saber: O EU, sujeito produtor do ato de linguagem e o TU, sujeito interlocutor desse ato. Entretanto, enfatiza que o papel do TU não concerne apenas à função de recepção da mensagem. O TU é compreendido como sujeito ativo no processo, pois atua na construção de uma interpretação. Esse ato interpretativo está relacionado a um ponto de vista que é suscitado no processo de apurar as intenções do EU. Sob essa perspectiva, o ato de linguagem pressupõe uma relação dialética entre dois processos, de produção e de interpretação.

Nesse jogo, entre explícitos e implícitos, esse processo relacional se estrutura entre dois circuitos, um externo (situacional) e outro interno (discursivo). Essa relação é constituída por quatro sujeitos.

2 Concepção de lugar antropológico (AUGÈ, 2010), no qual há a possibilidade de se constituir processos de inclusão, legitimação e reconhecimento. 
No circuito situacional temos o Sujeito Comunicante (EUc) e o Sujeito Interpretante (TUi). No sentido discursivo/da fala, encontramos o Sujeito Enunciador (EUe) e o Sujeito Destinatário (TUd).

Para esclarecer esses processos, expomos, de acordo com Charaudeau (2001), as representações de cada sujeito. O EUe é um sujeito de fala, assim como o TUd. O sujeito enunciador é uma imagem de fala que oculta o EUc, em maior ou menor grau. O EUe é uma máscara de discurso usada pelo sujeito comunicante. Esse, por sua vez, é o sujeito agente, responsável pela organização do ato de linguagem. O sujeito destinatário (TUd), é um sujeito produzido pelo EU no momento de produção/organização do discurso. Já o TUi, é um sujeito independente da esfera produtiva do EU, é responsável pelo ato de interpretação que produz.

Nesse processo de produção, destacamos que o EUe, o sujeito de fala, tem uma intencionalidade psico-sócio-discursiva que determinará o seu ato de linguagem, a partir da sua construção do TUd. Assim, Charaudeau (2006) propõe seis principais visadas discursivas: prescrição, solicitação, incitação, informação, instrução e demonstração.

No caso da análise do Pão de Açúcar, destacamos a visada da incitação, na qual o consumidor da publicidade é conduzido por um "fazer acreditar". A partir de elementos de sedução, representativos do prazer, da liberdade, da alegria, dos encontros, o sujeito é levado a um dever apreciar e, portanto, se aproximar, se identificar, com o discurso que está sendo proposto. O EU, em verdade, deseja "mandar fazer", mas como não está em posição de autoridade para tanto, recorre à incitação para colocar o TU em posição de "dever acreditar".

O EU (Pão de Açúcar), por meio da incitação, busca, em seu discurso da felicidade, seduzir o TU. Nessa relação, o EUc (Pão de Açúcar), na figura do EUe (Clarice Falcão) considera que o TUd irá acreditar que comprar no Pão de Açúcar é "opção" do agente/consumidor em escolher o mais saudável, o mais atraente. Decisão que o levará à sensação de bem-estar, de felicidade. A seguir, reproduzimos a letra da música interpretada por Clarice Falcão (CLARICE FALCÃO CANTA, 
2015).

\author{
O que faz você feliz? \\ você feliz o que faz? \\ você faz o que te faz feliz? \\ o que faz você feliz, você quem faz? \\ pra ser feliz \\ o que você faz pra ser feliz? \\ se a felicidade voa num balão \\ tão alto onde já não se enxerga mais \\ mas só ela pode the tirar do chão \\ pra ser feliz o que é que você faz? \\ a felicidade está por dentro \\ mas não vai sair no raio $X$ \\ você provoca os próprios sentimentos \\ o que você faz pra ser feliz? \\ pra ser feliz \\ o que você faz pra ser feliz \\ longe, perto ou dentro, tanto faz \\ quem quer felicidade corre atrás \\ e as vezes ela está de baixo do nariz \\ o que você faz pra ser feliz \\ pra ser feliz.
}

"O que você faz pra ser feliz?". O discurso é construído no intuito de despertar o protagonismo no sujeito, buscar o bem-estar, o que é saudável, porque, afinal, "quem quer felicidade corre atrás". O Pão de Açúcar, em seu discurso, anuncia que seus valores e princípios estão comprometidos com essas perspectivas, assim como os seus produtos, suas atitudes e espaços de ambiência/convivência.

A música é trilha sonora de uma construção de cenas prosaicas, representativas da felicidade, baseadas na simplicidade do cotidiano, como um café da manhã, intercaladas com cenas de estúdio da cantora e sua banda. Importa ressaltar que tais cenas podem estar, em certa medida, distantes de nossa realidade ordinária, como a cena que apresenta um casal de idosos em um balanço. Mas, estão baseadas em uma estrutura de simplicidade, pois não envolvem elementos complexos, inacessíveis. Eles podem estar à disposição na praça perto de casa. Além disso, ao mesmo tempo em que verbaliza que a felicidade está acessível a todos, parece vincular tal conceito à juventude. Essa 
questão está implícita em diversos pontos do discurso, associando-o aos hábitos e às práticas dos jovens e das crianças.

O EU incita o sujeito a ir atrás da felicidade, presumindo que o TUd está em busca de experiências, de vivenciar sensações calcadas na simplicidade, nos relacionamentos, no comer bem, naquilo que possa ser saudável para o corpo e para a mente. Mesmo que, em nenhum momento, seja verbalizada no discurso, a prerrogativa - Venha para $o$ Pão de Açúcar, aqui você pode vivenciar isso - se apresenta de maneira implícita.

A fotografia do filme publicitário, atrelada ao jogo de cenas articuladas com a música, busca despertar elementos de identificação no público. Nesse sentido, o propósito do EUc (Pão de Açúcar) é, através do EUe (Clarice Falcão associada aos demais elementos construídos e apresentados no vídeo/discurso), despertar no TUi empatia. Ou seja, o Pão de Açúcar, nesse discurso, de forma implícita, objetiva apresentar que a felicidade - objeto de desejo do TUd - está na simplicidade do cotidiano, nos fazeres do dia a dia. Os produtos ofertados em um supermercado são artigos de necessidade básica, de funcionalidade e consumo diário. Associa-se, portanto, a essa materialidade, princípios relacionados à saúde, à qualidade de vida, à beleza, enfim, todos reunidos em torno de uma experiência maior: sentir-se feliz.

Propomos uma interpretação sobre os sujeitos de fazer (EUc-TUi) e de dizer (EUe-TUd) a partir da articulação com os sujeitos do discurso publicitário do Pão de Açúcar, objeto desta análise. Essa aproximação/ articulação se deu no sentido de refletirmos sobre como os papéis e as relações se estabelecem nesse discurso, para além do produto explícito veiculado. Conforme Charaudeau (2010), o discurso publicitário serve "aos interesses específicos daqueles que o promovem" (CHARAUDEAU, 2010, p. 74). Entretanto, como vimos, essa é uma construção dialética entre produção e interpretação e, portanto, incorpora elementos do âmbito social e as subjetividades dos sujeitos em relação nesse processo. Nesse sentido, buscamos, a seguir, realizar uma aproximação desta análise com as considerações sobre a memória no processo discursivo. 


\section{$A[s]$ memória[s] na comunicação: possíveis olhares}

De acordo com Charaudeau (1997), o sujeito é composto por três tipos de memórias: memória dos discursos, memória das situações de comunicação e memória das formas de signo. Apresentaremos a seguir, resumidamente, os pressupostos que concernem cada uma delas.

A memória dos discursos está relacionada à produção de conhecimento e de crenças $^{3}$ sobre o mundo. Esses discursos são responsáveis pela construção das identidades coletivas dos grupos que formam a sociedade, aos quais podemos estar vinculados, ou não, a partir de um processo de identificação. Para explicitar esse processo de identificação, podemos nos valer do pensamento de Hall, para quem a identidade

[...] permanece sempre incompleta, está sempre "em processo", sempre "sendo formada". [...] Assim, em vez de falar da identidade como uma coisa acabada, deveríamos falar de identificação, e vê-la como um processo em andamento. [...] uma falta de inteireza que é "preenchida" a partir de nosso exterior, pelas formas através das quais nós imaginamos ser vistos por outros (HALL, 2002, p. 38-39, grifos do autor).

A partir do que postula Stuart Hall, consideramos que o discurso da felicidade ordinária do Pão de Açúcar busca estabelecer pontos de identificação com os sujeitos, preenchendo-os com sentidos que significam uma sociedade hedonista. Essa é uma das principais características da sociedade contemporânea, de acordo com os pensadores da pós e da hipermodernidade, aproximados nesta análise reflexiva.

[...] a memória é um elemento constituinte do sentimento de identidade, tanto individual como coletiva, na medida em

\footnotetext{
3 As crenças dão conta do mundo quanto à maneira de proceder à regulação das práticas sociais, ao se criarem normas efetivas de comportamento, e também quanto aos discursos de representação produzidos no âmbito do grupo social, para avaliar esses comportamentos, criando-se, assim, normas ideais. Essas apontam não apenas para os imaginários de referência dos comportamentos (o que se deveria fazer ou não fazer), mas também para os imaginários de justificativa desses comportamentos (se é do bem ou do mal) (CHARAUDEAU, 2006, p. 46, grifos do autor).
} 
que ela é também um fator extremamente importante do sentimento de continuidade e de coerência de uma pessoa ou de um grupo em sua reconstrução de si. (POLLAK, 1992, p. 203).

É através da seleção de determinados elementos que se constitui um discurso midiático, objetivando estimular sentimentos que permanecem na memória, direta ou indiretamente registrados. Tanto as memórias individuais ${ }^{4}$, quanto coletivas ${ }^{5}$, são construções que estão sujeitas a transformações e flutuações. Conforme Pollak (1992), a memória é constituída por três elementos: os acontecimentos vividos pessoalmente; os acontecimentos hereditários, quando se refere a fatos presenciados pelo grupo ao qual a pessoa se sente pertencer, ou seja, que não são vivenciados pessoalmente, mas apropriados por meio do imaginário; e a memória constituída por pessoas e personagens, podendo-se ainda considerar os lugares de memória, aqueles associados a alguma lembrança.

Compreendemos a memória a partir de um processo relacional, em que a formação do eu é inseparável dos valores sociais pré-estabelecidos no grupo em que está situado (CATROGA, 2001). Na interação entre temporalidades distintas e na coexistência da memória privada com a pública, a evocação não é um ato isolado, que se desenvolve apenas no interior dos indivíduos, ela necessita de suportes tangíveis, sociais e simbólicos para o seu despertar. Nesse sentido, apontamos à potencialidade do discurso publicitário do Pão de Açúcar como a tangibilidade na evocação de memórias em seus públicos. 0 despertar dos diferentes elementos que constituem a memória, de acordo com Pollak (1992), podendo conduzir, assim, a processos de

4 De acordo com Catroga (2001), a memória individual é formada pela coexistência tensional de várias memórias (pessoais, familiares, nacionais, organizacionais etc.) em permanente (re)construção devido à constante mudança do presente em passado e as alterações de percepções sobre o pretérito. "Significa isto que a anamnese, enquanto presente-passado, é experiência interior na qual a identidade do eu unifica a complexidade dos tempos sociais em que cada vida individual comparticipa" (CATROGA, 2001, p. 16).

5 Em seus estudos, Halbwachs (1990) busca compreender os quadros sociais que compõem a memória. Para ele a memória aparentemente mais particular remete a um grupo. O indivíduo carrega em si a lembrança, mas está sempre interagindo com a sociedade, seus grupos e instituições. 
identificação.

Inútil esperar que nossas lembranças que afloram no presente sejam cópias fiéis das realidades vividas no tempo que passou. Nossas lembranças do passado são recriadas no instante presente, com o acervo que detemos no momento da recuperação dessas informações (COSTA, 1997, p.136).

A narrativa apresentada pelo Pão de Açúcar não necessariamente remonta momentos já vivenciados pelos seus públicos, mas situações que representam alegria, descontração, beleza e fluidez. Nesse sentido, podemos indicar que esse discurso publicitário atua sobre a (re)criação de lembranças, a partir das sensações e expectativas despertadas no sujeito interpretante no momento presente, ou seja, na observação/interação com o discurso. A memória, dessa forma, se constitui como processo essencial na formação de identificações entre o Pão de Açúcar e seus públicos, uma memória que (re)age a partir de um discurso publicitário.

O segundo tipo de memória, denominado memória das situações de comunicação, faz referência aos elementos que normatizam as trocas comunicativas, constituídos sobre um conjunto de condições psicossociais. Portanto, essa memória é responsável pelas representações dos sujeitos.

A construção/encenação de fragmentos da realidade social, proposta no discurso publicitário do Pão de Açúcar, apresenta um jogo de cenas, articuladas com a música, que reúnem ações e relacionamentos prosaicos. As cenas interligam uma série de elementos, como jovens, crianças, idosos, momentos em família, amizade, esporte, namoro, belas paisagens, animais de estimação, momentos de sociabilidade, turismo, diversão, entre outros. A narrativa, baseada nessa construção iconográfica, pressupõe uma memória comunicacional, na qual os sujeitos poderão lembrar situações vivenciadas e/ou evocar representações desejadas desses momentos que remetem a uma representação maior: a felicidade. Portanto, embora, muitas vezes, seja verbalizada a palavra felicidade na música, as cenas apresentadas 
estão reverberando esse conceito, de forma implícita, baseadas nas referências da(s) memória(s) das situações de comunicação. De acordo com Pierre Nora (1993, p.20), a "memória é intensamente retiniana e poderosamente televisual".

É possível, ainda, destacarmos a memória das formas de signos, sobre as maneiras de dizer que estabelecemos (gestuais, verbais, icônicas etc.). Essa memória está relacionada, portanto, ao "estilo" que orienta as maneiras de falar. No caso do Pão de Açúcar, podemos perceber um "estilo", que estrutura a sua relação publicitária com o público. Como vimos, a temática da felicidade, da sustentabilidade, do bem-estar, são questões que estão incorporadas ao seu "estilo". A forma como apresentam esse discurso faz parte de uma memória de signos, associados à simplicidade, ao dia a dia, à juventude, à qualidade de vida, aos relacionamentos, às escolhas. O fato de ter essa memória já estabelecida não exclui a possibilidade de serem agregados novos elementos, ampliando, dessa forma, essa "base memorialística" associada à marca.

Nesse aspecto, sobre a memória atrelada às maneiras de dizer, chamamos atenção para o "estilo" reverberado pela música escolhida para a campanha. Com um ritmo simples, dançante e envolvente, associado a um refrão marcante, a marca Pão de Açúcar pode acabar fazendo parte das memórias de diferentes sujeitos, inclusive aqueles que nunca estiveram presentes em alguma de suas lojas. Dessa forma, pode-se estabelecer relação, e até mesmo identificação, mesmo antes de um contato presencial, ou seja, de vivência em alguma loja. O discurso publicitário, sob este enfoque, mobiliza memórias no processo comunicacional. A memória, portanto, enquanto substrato para o desenvolvimento de relacionamentos da marca com os públicos.

\section{Considerações finais}

De acordo com Lipovetsky e Serroy (2015), há um novo espírito publicitário, no qual "[...] propagandas evocativas ou emocionais criam 
uma ambiência, uma cumplicidade, uma identificação" (p. 222), dessa forma, "[...] o produto conta uma história, suscita emoções, reaviva as cores da memória" (p. 246). É sob esta perspectiva que enfatizamos a memória enquanto processo de "lugarização" (AUGÉ, 2010) do discurso publicitário.

Hoff (2015), considera a publicidade como promotora de biossociabilidades ${ }^{6}$, revelando as relações de poder implicadas nos modos de divulgação das marcas e na produção de sentidos sobre elas. Nesse sentido, destacamos a memória como processo dessas (re) constituições.

Com relação à felicidade, temática central do filme analisado, é possível entendermos a força dos apelos contemporâneos da mídia quando consideramos que o próprio conceito está no âmago do fenômeno da cultura de massa. Conforme nos fala Morin (1967, p. 135): "[...] a cultura de massa foge do fracasso, essa segunda face da vida, pelo alarde de felicidade mitológica". Parece haver, assim, uma crença e uma busca permanente pela felicidade, que pode contribuir para o estabelecimento de pontos de identificação com o discurso publicitário.

Considerando a relação de consumo em que são produzidos os sentidos do discurso publicitário, é possível, ainda, pensarmos na memória das situações de comunicação como uma memória da situação de consumo. Há uma experiência de consumo desses sujeitos. Percepções e vivências que são constantemente (re)criadas. Satisfações e frustrações que podem ser evocadas pelo sujeito consumidor/ interpretante, constituindo essa memória de consumo, que pode levar a questionamentos como: fui feliz quando comprei no Pão de Açúcar?

Outra dimensão dessa memória de consumo, além da experiência individual, é aquela relacionada a padrões de consumo estabelecidos socialmente (DOUGLAS, 2007). Neste caso, o prazer de comprar, o

6 "[...] biossociabilidade refere-se aos critérios de mérito e reconhecimento; aos valores com base em regras higiênicas, aos regimes de ocupação de tempo, à criação de modelos de sujeitos baseados no desempenho físico. De modo geral, a noção de biossociabilidade permite escrever e analisar as novas formas de sociabilidade, constituídas na interação do capital e do ideário das culturas do consumo com as biotecnologias e a medicina" (HOFF, 2015, p. 172). 
bem-estar criado pelo consumo, como construção coletiva da sociedade contemporânea, de certa forma, justifica a associação entre Pão de Açúcar e felicidade.

Orofino e Nunes (2015, p. 288) enfatizam a importância de considerarmos, na contemporaneidade, a memória em sua interface comunicação-consumo, não só como arquivo, mas a memória como prospecção. As autoras colocam que, dessa forma, "[...] pensamos o consumo de memórias e as memórias consumidas em suas múltiplas materialidades inscritas em complexas dinâmicas de tempo e espaço".

A reflexão desenvolvida neste artigo teve como objetivo evidenciar os implícitos que se encontram na formação de um discurso publicitário. Para tanto, nos valemos da proposta de comunicação contratual desenvolvida por Charaudeau. Um contrato que se estrutura no interior da realidade social e que, portanto, está carregado de seus valores, princípios, estruturas e subjetividades individuais e coletivas. Nesse sentido, buscamos apresentar como a temática da felicidade, apropriada pelo Pão de Açúcar, assume suas significações e representações na sociedade contemporânea. A marca vale-se de uma base de memórias sociais (POLLAK, 1992), buscando despertar cadeias de identificações a partir de um discurso que se sustenta sobre as tangibilidades, relações e subjetividades que regem o nosso "ideal" de cotidiano.

A aproximação sobre a relação da memória nesse processo de produção, apreensão, (re)significação e representação indica possibilidades de compreensão sobre como perspectivas conceituais em torno da memória podem estar associadas aos processos de comunicação. A intenção é provocar caminhos de apreensões sobre a memória enquanto processo do/no discurso comunicacional.

\section{Referências}

AUGÈ, Marc. Por uma antropologia da mobilidade. Maceió: Editora Unesp/ UFAL, 2010.

CASTRO, Marília Dias de. Reflexões sobre o discurso publicitário. In: XI Encontro COMPós. Anais. Rio de Janeiro: Compós, 2002. 
CATROGA, Fernando. Memória, História e Historiografia. Coimbra: Quarteto Editora, 2001.

CHARAUDEAU, Patrick.O discurso propagandista: uma tipologia. In: MACHADO, Ida Lúcia; MELLO, Renato. Análises do discurso hoje, vol. 3. Rio de Janeiro: Nova Fronteira, 2010, p. 57-78.

. Discurso das mídias. São Paulo: Contexto, 2006.

Uma teoria dos sujeitos da linguagem. In: MARI, H.; MACHADO, I.

L; MELLO, R. Análise do Discurso: fundamentos e práticas. Belo Horizonte: NAD/FALE/UFMG, 2001, p. 23-38.

COSTA, Arnaldo João Dalla.O Pão de Açúcar e a passagem do poder nas empresas familiares: um caso de sucesso. In: CIÊNCIA \& OPINIÃo. Curitiba, v. 1, n. 2/4, jul. 2003/dez. 2004, p. 193-221.

COSTA, IcléiaThiesen M. Memória Institucional: a construção conceitual numa abordagem teórico-metodológica. Rio de Janeiro: Tese apresentada ao Curso de Doutoramento em Ciência da Informação (CNPq/IBICT), 1997.

DOUGLAS, Mary. O mundo dos bens, vinte anos depois. Horizontes Antropológicos, Porto Alegre, ano 13, n. 28, p. 17-32, jul./dez. 2007.

FREIRE FILHO, João. Fazendo Pessoas Felizes: o poder moral dos relatos midiáticos. In: XIX Encontro da Compós. Anais...Rio de Janeiro, COMPÓS, 2010.

HALBWACHS, Maurice. A Memória Coletiva. São Paulo: Ed. Vértice, 1990

HALL, Stuart. A identidade cultural na pós-modernidade. 7a ed. Rio de Janeiro: DP\&A, 2002.

HOFF, Tânia Márcia Cezar. Biossociabilidades do consumo: regimes de visibilidade da diferença no discurso publicitário. In: In: ROCHA, Rose de Melo; PERES-NETO, Luíz. Memória, Comunicação e Consumo: vestígios e prospecções. Porto Alegre: Editora Sulina, 2015.

LIPOVETSKY, Gilles; SERROY, Jean. A estetização do mundo: viver na era do capitalismo artista. São Paulo: Companhia da letras, 2015.

LIPOVETSKY, Gilles. A felicidade paradoxal: ensaio sobre a sociedade de hiperconsumo. São Paulo: Companhia das letras, 2007.

MAFFESOLI, Michel. O instante eterno: o retorno do trágico nas sociedades pós-modernas. São Paulo: Zouk, 2003.

MAFFESOLI, Michel. O tempo retorna: formas elementares da pósmodernidade. Rio de Janeiro: Forense Universitária, 2012.

MORIN, Edgar. Cultura de massas no século vinte (o espírito do tempo). Rio de Janeiro: Companhia Editora Forense, 1967.

NORA, Pierre. Entre memória e história: a problemática dos lugares. In: 
Revista Projeto História. São Paulo: Departamento de História de Pontifícia Universidade Católica de São Paulo / PUC-SP, n.10, 1993, p. 07-28.

OROFINO, Maria Isabel; NUNES, Mônica Rebecca Ferrari. Posfácio: memória, comunicação, consumo: vestígios e prospecções. In: ROCHA, Rose de Melo; PERES-NETO, Luíz. Memória, Comunicação e Consumo: vestígios e prospecções. Porto Alegre: Editora Sulina, 2015.

POLLAK, Michael. Memória e identidade social. In: Estudos Históricos. Rio de Janeiro: Vol. 05, n.10, 1992, p. 200-212.

SANTOS, CarolyneMaryane Cardoso. Promessa de marca e a construção do marketing de valores: o caso do supermercado Pão de Açúcar. Monografia apresentada ao curso de Comunicação Social com habilitação em Publicidade e Propaganda da Faculdade de Comunicação Social da Universidade de Brasília. Brasília, 2013.

\section{Sites consultados}

CLARICE FALCÃO CANTA. Grupo Pão de Açucar. Site institucional. Disponível em: <http://exame.abril.com.br/marketing/noticias/clarice-falcao-cantaem-campanha-do-pao-de-acucar> Acesso em: 01 de Jul. de 2015.

GRUPO PÃO DE AÇUCAR. Site institucional. Disponível em: <http://www. gpabr.com/home.htm> Acesso em: 01 de Jul. de 2015. 


\section{USOS E INSTRUMENTALIZAÇÕES DA MEMÓRIA EM REABERTURAS DE ANTIGOS CINEMAS: DE ROMA, UM CASO BELGA}

\section{Edição v.35} número 3 / 2016-17

Contracampo e-ISSN 2238-2577 Niterói (RJ), v. 35, n. 3

dez/2016-mar/2017

A Revista Contracampo é uma revista eletrônica do Programa de Pós-Graduação em Comunicação da Universidade Federal Fluminense e tem como objetivo contribuir para a reflexão crítica em torno do campo midiático, atuando como espaço de circulação da pesquisa e do pensamento acadêmico.

\section{INSTRUMENTAL USES OF MEMORY IN REOPENING PROJECTS OF OLDER} CINEMAS: DE ROMA, A BELGIAN CASE

\section{TALITHA GOMES FERRAZ}

Talitha Ferraz é doutora em Comunicação e Cultura pela ECO-UFRJ e realizou pós-doutorado no Centre For Cinema and Media Studies da Ghent University (CIMS-UGent). É docente na ESPM-Rio, líder do Grupo de Pesquisa Modos de Ver (ESPM/ CNPq), e pesquisadora associada à Coordenação Interdisciplinar de Estudos Contemporâneos da UFRJ (CIEC-UFRJ). Brasil.

talitha.ferraz@gmail.com

\section{PPG $\mid C O M$ andicasio UFF}

FERRAZ, Talitha Gomes. Usos e instrumentalizações da memória em reaberturas de antigos cinemas: De Roma, um caso belga.

Contracampo, Niterói, v. 35, n. 03, dez. 2016/ mar. 2017.

Enviado em 10 de setembro de 2015 / Aceito em: 09 de março de 2016. 


\section{Resumo}

Analisamos os usos estratégicos das memórias ligadas a antigas salas de exibição e práticas de cinemagoing por projetos de reabertura de cinemas. O foco deste trabalho é o caso do cine De Roma, localizado na Antuérpia, Bélgica, reaberto como um teatro popular por meio de um conjunto de ações da sociedade civil e instâncias governamentais locais. Com base nas representações do passado cinematográfico do equipamento e de sua imagem como forte ponto referencial local e exímio "lugar de memória", o processo de reativação do De Roma e as dinâmicas socioculturais e políticas efetivadas ao seu redor envolvem uma série de questões ligadas à gestão da "memória coletiva" das audiências. À luz do paradigma New Cinema History, cremos que o enquadramento estratégico da memória e a legitimação de determinadas versões sobre o passado do De Roma dizem respeito a esferas ligadas à organização social e do lazer locais e a dinâmicas concernentes às políticas culturais belgas. A partir disso, sugerimos que os projetos de reabertura de históricas salas de cinema precisam ser observados como peças de enredadas táticas de gestão da cultura e das memórias das audiências.

\section{Palavras-chave}

ida ao cinema; reabertura de cinemas; memória; New Cinema History

\section{Abstract}

We analyze the strategic uses of the memories related to former movie theatres and cinema-going practices by cinema reopening projects. This paper focuses on the case of the De Roma cinema, located in Antwerp, Belgium, which was reopened as a popular theatre through a series of interactions between civil society and governmental bodies. Based on the representation of the cinematic past of the equipment and its image as a strong urban landmark and a "realm of memory", the reactivation processes of the De Roma and sociocultural dynamics around it involve a range of issues concerning with the management of the audiences' collective memories. In the light of the New Cinema History paradigm, we believe that the strategic "memories framings" as well as the legitimation of particular versions about the De Roma past concern spheres connected to the local social structure and leisure practices in addition to dynamics related to the Belgian cultural policies. Based on this, we suggest the projects of reopening historical cinemas should be observed as parts of tactics to manage culture and audiences' memories.

\section{Keywords}

cinema-going; cinema reopenings; memory; New Cinema History 


\section{Introdução: um cenário de reaberturas}

Nos últimos anos, o tema sala de cinema vem ganhando destaques significantes na Bélgica em meio às dinâmicas socioculturais de algumas esferas da sociedade, às atenções da mídia e às políticas culturais implementadas pelas comunidades linguísticas/ governamentais francesa e flamenga que formam o estado pilarizado belga ${ }^{1}$. A Comunidade Francesa belga, por exemplo, na figura do Centre du Cinéma et de l'Audiovisuel, dedica boa parte de suas atuais preocupações com o cinema nacional, incluindo nesse bojo questões como a criação de novos cinemas de arte e ensaio e a reativação de notáveis salas de exibição atualmente extintas. Em seu relatório anual de 2015, o órgão menciona a retomada dos cinemas Caméo e Le Palace, ambos antigos cinemas de rua das cidades de Namur e Bruxelas, e ressalta que iniciativas em prol da abertura de salas de exibição se ligam diretamente aos esforços para a difusão dos filmes belgas no país:

O primeiro elemento essencial é a abertura de novas salas de cinema. O ano de 2015 será um ano importante nesse aspecto. Três cinemas dedicados a filmes de arte e ensaio deverão abrir as suas portas: Le Caméo ( 5 telas) em Namur, Le Quai 10 (4 telas) em Charleroi e Le Palace (4 telas) em Bruxelas; essas 13 novas telas serão muito importantes para a difusão de nossos filmes porque elas darão a eles novas oportunidades de serem vistos por um grande público. Além disso, não há nenhuma restrição concernente à difusão de filmes belgas em salas de arte e ensaio subvencionadas. Assim, como já se pratica no setor de artes e encenações, os dispositivos contratuais serão implementados em prol dos filmes belgas (CENTRE DU CINÉMA ET DE L'AUDIOVISUEL, 2015, tradução nossa).

Em um nível paralelo a este breve exemplo concernente à esfera governamental, autores belgas ligados aos cinema-going studies, isto

\footnotetext{
1 A Bélgica é um país territorialmente dividido em três comunidades linguísticas, sociopolíticas e culturais: a Comunidade Francesa, a Comunidade Flamenga - que são mais fortes e maiores em número de cidadãos e área de abrangência - e a Comunidade Alemã. Numa segunda linha de divisão do poder estatal, estão as regiões que têm autonomias econômicas e políticas: Valônia, Bruxelas (a capital bipartida entre as comunidades francesa e flamenga) e Flandres. A ideia de pilarização, isto é, de uma sociedade que se divide verticalmente, como em pilares, pode ser aplicada a este tipo de estrutura. Cada uma das comunidades belgas tem orçamentos e instâncias governamentais independentes, que, por sua vez, não invalidam a existência do governo federal, que inclui o Parlamento e a Família Real (PORTAL BELGIUM.BE, 2012).
} 
é, os estudos das práticas de ida ao cinema, têm estruturado uma série de pensamentos e análises historiográficas acerca da proeminência das salas de cinema nos contextos urbanos e do papel que tais equipamentos desempenham/desempenharam na construção de uma memória da espectação cinematográfica. Isso inclui, entre outros aspectos, a verificação de como se dá ao longo do tempo a inserção dos equipamentos de exibição (presentes ou ausentes nas ruas) nos mapas afetivos e modos de lazer dos espectadores em algumas localidades da Bélgica. Essa recente corrente de estudos vinculada à história do cinema segue um caráter transdisciplinar e se inspira por aquilo que seus pesquisadores chamam de cinema culture: um domínio extenso que não desassocia a cultura cinematográfica e as práticas das audiências dos contextos sociais, econômicos, culturais e políticos locais/globais.

Tal panorama de investigação, entretanto, não se restringe ao cenário acadêmico belga e se espalha por departamentos de Cinema e Mídia de universidades de outras regiões da Europa (Holanda, Inglaterra, Escócia, Alemanha, por exemplo), além de Austrália e EUA etc. ${ }^{2}$, as análises desenvolvidas nesse âmbito, em linhas gerais, têm como foco a cultura do cinema e abraçam tudo aquilo que tangencia o equipamento sala de cinema (suas localizações nas cidades, tipos de programação e seus usos cotidianos pelas pessoas, por exemplo). Uma vasta produção de artigos e livros vem sendo produzida dentro do que os pesquisadores dessa linha batizaram como New Cinema History, paradigma que considera os cinemas muito mais do que simples espaços neutros ligados à era das velhas mídias modernas.

Segundo o New Cinema History a triangulação formada pela sala de cinema, filmes exibidos/programação e consumos das audiências foi em alto grau elipsada dentro da ortodoxia da Grande História do Cinema, que, de algum modo, preteriu essa interconexão em favor

2 A rede Homer Project - The History of Moviegoing, Exhibition and Reception, por exemplo, foi criada em 2004 para reunir pesquisadores internacionais que trabalham com estudos multidisciplinares ligados à prática de cinema-going (ida ao cinema), à exibição cinematográfica e à recepção. Disponível em: http:// homernetwork.org/about/ . Acesso em: 9 out. 2015. 
das preferências pelos estudos fílmicos. Simultaneamente, também há certo incômodo desta nova corrente com o habitual dualismo conceitual e metodológico entre "texto" e "contexto" no cinema, que divorcia os estudos fílmicos/análise fílmica de seu pano de fundo industrial, cultural e histórico, e vice-versa (KUHN, 2002, p.4).

Na medida em que os estudos de cinema privilegiam o texto do filme, por exemplo, eles vão minimizar não só a recepção dos filmes pelo público, mas também os contextos social e histórico e as configurações industriais e institucionais em que os filmes são produzidos e consumidos (...). No entanto, se a análise fílmica às vezes é conduzida como se os filmes não fossem produzidos e consumidos por pessoas em determinadas épocas e lugares, os estudos da mídia e audiências baseados nas Ciências Sociais rotineiramente marginalizam os textos midiáticos, tratando-os como meros epifenômenos das suas condições de existência social, cultural ou industriais (KUHN, 2002, p.4, tradução nossa).

Um dos pontos especiais do New Cinema History é a proposta de que os equipamentos sala de cinema são peças inseparáveis de fatores econômicos, políticos, culturais, geográficos e, obviamente, cinematográficos. Além disso, nessas análises não há isolamentos entre os eixos de produção, exibição, distribuição e estruturas do consumo cinematográficos. Deste modo, por meio de variadas metodologias e métodos emprestados da etnografia, história oral, análise do discurso etc., e com apreço pela produção de bases de dados quantitativos e mapeamentos, os autores ligados ao New Cinema History desenvolvem um pensamento vigoroso sobre a sala de exibição e a cultura da ida ao cinema, em vista da vida cotidiana das audiências, da memória dos espectadores, das esferas ideológicas e de poder, do gosto, das afirmações identitárias locais etc. (BILTEREYST E MEERS, 2011; LOTZE e MEERS, 2013; MALTBY, BILTEREYST, MEERS, 2012; KUHN, 2002).

O Cinema se tornou um assunto de interesse histórico para investigadores que não foram educados pela ortodoxia profissional, para a qual o tema adequado aos estudos de cinema são os estudos fílmicos. Do ponto de vista da geografia histórica, história social, economia, estudos de antropologia ou da população, a observação de que os cinemas são espaços de importância social e cultural tem muito a ver com os padrões de emprego, o desenvolvimento urbano, os sistemas de transporte e as práticas de lazer que 
formam a difusão cinematográfica global (...). O New Cinema History oferece uma interpretação que complementa e é informada por vários aspectos da história cinematográfica, particularmente pelas investigações das condições globais de produção, das inovações técnicas e artísticas e das múltiplas e interligadas culturas organizacionais que caracterizam a indústria da produção cinematográfica. $A$ isso acrescenta o conhecimento das operações históricas das redes mundiais dos negócios de distribuição e exibição, e das formas como estas redes interligadas de interesses corporativos globais, franquias locais e outras pequenas empresas têm gerenciado conjuntamente 0 fluxo dos produtos cinematográficos nos cinemas mundiais e outros espaços. Ele [New Cinema History] usa informações quantitativas articuladas através dos aparatos de bases de dados, análise espacial e geovisualização para avançar numa série de hipóteses sobre a relação dos cinemas com agrupamentos sociais, na expectativa de que estas hipóteses sejam testadas de outras formas, qualitativas. Demostrando uma gama de materiais de arquivo próprios aos âmbitos da história operacional e institucional do cinema, o New Cinema History vai fortemente de encontro à adequação a uma história total do cinema baseada no estudo fílmico. Ao mesmo tempo, o New Cinema History oferece uma contraproposta à suposição de que o que importa no estudo sobre a experiência da audiência deve se limitar à "recepção" - isto é, ao que acontece nos momentos em que o público está principalmente focado na tela ou quando os espectadores estão pensando sobre o filme e seus possíveis significados após assisti-lo (MALTBY, 2011, p. 12 , tradução nossa).

Localizamos a nossa análise $^{3}$ justamente no rastro de tais tendências investigativas, conectando-a ao atual conjunto de discussões e ações em torno da importância das salas de cinema/ prédios da exibição para a configuração do espaço urbano. As pesquisas acadêmicas, discussões gerais e ações desenvolvidas nesse domínio têm direcionado o olhar para a intensa participação dos cinemas na produção da "memória dos lugares urbanos" (JODELET, 2010) e das memórias pessoais dos indivíduos. Aliados à consideração de que os cinemas são "espaços de importância social e cultural", cuja história operacional e institucional está articulada à experiência de audiências e

\footnotetext{
3 As discussões lançadas neste artigo vinculam-se diretamente à corrente New Cinema History e fazem parte da pesquisa "Public-Private Partnerships as a reaction to closed movie theaters: A comparative study between the suburban Cinecarioca Méier in Rio de Janeiro and Belgian cases of reopening cinemas", desenvolvida pela autora durante estágio pós-doutoral no Centre for Cinema and Media Studies da Ghent University, Bélgica, entre fevereiro de 2015 e fevereiro de 2016, no âmbito do Programa de Pesquisa Pósdoutoral no Exterior da Capes.
} 
agrupamentos sociais (MALTBY, 2011, p. 12), neste artigo verificaremos como procedem alguns usos e instrumentalizações da memória do cinema e das práticas de cinema-going no âmbito de um episódio bem específico de reativação de antigos cinemas da Bélgica: o caso do cine De Roma, que, após longos 20 anos de abandono, reabriu as portas em 2003 como um teatro popular.

Situado no distrito do Borgerhout, na Antuérpia, uma das regiões flamengas da Bélgica, o caso deste antigo cinema é um destaque entre as reaberturas de cinemas belgas empreendidas na contemporaneidade. A particularidade de seu processo de reativação, conforme veremos mais adiante, se deve a uma série de dinâmicas socioculturais e sociopolíticas e a determinados usos da memória que se apoiam numa rede de narrativas sobre as práticas de cinema-going efetivadas nesse espaço ao longo da segunda metade do século $X X$. Desde o início de sua recuperação, em 2002, é realizado um trabalho constante de renovação das estruturas originais do equipamento, que conta basicamente com os esforços de uma comunidade de antigos frequentadores e entusiastas. O fio condutor desses esforços é a luta pela manutenção dos vínculos do De Roma com a região do Borgerhout, tendo em vista a sustentabilidade do equipamento no presente, os traumas comunitários ligados ao longo período de seu fechamento e o passado de glória da casa onde, acredita-se, há décadas atrás "Todo mundo [do Borgerhout] esteve pelo menos uma vez" (DE ROMA, A UNIQUE... p.2, tradução nossa).

\section{Salas de cinema como lugares de memória}

A instrumentalização da(s) memória(s) dos cinemas e seus frequentadores geralmente aparece infiltrada em projetos de reabertura de salas exibidoras. Cremos que basicamente ela se vale de redes narrativas produzidas em torno das representações de cinemas antigos, tais como: 1) espaços quase perdidos, em busca de salvaguarda ou 
renascimento; 2) enclaves urbanos, dispositivos heterotópicos ${ }^{4}$ por excelência ligados à produção do sonho, a um outro tempo-espaço que se difere do vai-e-vem das calçadas; 3 ) e, sobretudo, local entrelaçado a uma gama variada de fortes reminiscências pessoais e grupais, o que não deixa de provocar manifestações de nostalgia.

Nas conceituações sobre a ideia de sala de cinema, é interessante citarmos o que Anette Kuhn (2002), uma das fundadoras do New Cinema History, diz sobre a íntima relação entre os prédios dos cinemas e os espectadores-transeuntes em seus trajetos diários. Em seu trabalho sobre os hábitos de ida ao cinema na Grã-Bretanha durante a década de 1930, a autora recorre ao pensamento de Michel de Certeau sobre práticas sociais e vida cotidiana para analisar as conversas que realizou com espectadores idosos. Kuhn se detém a observar o discurso produzido por ex-frequentadores de cinema a respeito de suas experimentações do espaço urbano há tempos atrás, quando eles ainda eram jovens e criavam trajetos rumo às salas de exibição das regiões onde moravam. Levando em conta que tais espectadores-transeuntes, nomeados por Kuhn como "cinemagoers" (2002, p. 35), se encaixam na figura de exímios praticantes da cidade/do espaço vivido, a autora destaca a maneira pela qual Certeau acentua as diferenças entre "nãopertencimento" e "pertencimento" a um lugar: o primeiro termo indica a existência de distâncias bem marcadas entre o observador e o objeto observado, onde uma forma de voyeurismo estaria em jogo; enquanto isso, o segundo termo refere-se à ideia de que "(...) pertencer a um lugar implica uma conexão somática, sensual, mesmo tática com ele" (KUHN, 2002, p. 35, tradução nossa).

Kuhn comenta que durante as entrevistas realizadas em seu trabalho de etnografia histórica ("ethno-history") - termo usado pela Antropologia Cultural do qual ela diz se apropriar (KUHN, 2002, p.

4 Aqui nos referimos à noção de espaço heterotópico foucaultiano, isto é, um espaço-outro, "uma espécie de contestação simultaneamente mítica e real do espaço em que vivemos (...)" (FOUCAULT, 1984, p.416). Michel Foucault menciona o cinema entre diversos tipos de heterotopia. Ele fala especificamente da sala de cinema, limitando-se ao arranjo interior do equipamento, dizendo que "o cinema é uma sala retangular muito curiosa, no fundo da qual, sobre uma tela em duas dimensões, vê-se projetar um espaço em três dimensões" (Idem). 
6) -, quando os interlocutores acionavam seus mapas de memórias pessoais, na maioria das vezes, os cinemas eram representados como "pontos de parada dentro do familiar", peças referenciais inseridas em meio a trajetos, feitos na escala do pedestre, entre a casa e a grande tela. Ela enfoca um ponto relevante: tais percursos, beneficiados pela disponibilidade de salas de cinema, imprimiram-se na memória corporal dos espectadores/transeuntes. Para a autora, um sentimento de pertença associado à conexão trajeto-cinema-espectadores/ transeuntes é evidenciado nos relatos dos interlocutores, ainda que o cerne familiar dos trajetos que eles executavam, conforme pondera Kuhn, fosse sempre interrompido por "uma excursão virtual para espaços não familiares, para outros mundos oferecidos pela tela do cinema" (KUHN, 2002, p. 6, tradução nossa).

Como profícuos locais ligados a múltiplos afetos e emoções, os cinemas se foram, mas de alguma maneira continuaram presentes nas impressões que as pessoas guardaram de seus caminhos, práticas e vivências no espaço construído das cidades. Diante disso, ao pensamos acerca dos cinemas reabertos, que parecem se valer das marcas deixadas por uma gama de experiências precedentes, percebemos que eles se apresentam como elementos estratégicos para a preservação de um passado latente, que, por razões diversas, precisará ser lembrado e revelado.

Cremos que a noção de sala de cinema reaberta se aproxima, em algum grau, do conceito de "lugares de memória" de Pierre Nora (1984). Apesar de discordarmos de que o projeto do De Roma exercite uma nostalgia paralisadora, de ode restrita ao passado, e mesmo indo de encontro à opinião de que este equipamento seja hoje um "empreendimento de piedade, patético e glacial", tal como Nora adjetiva alguns "lugares de memória", ainda assim, o conceito é válido para examinarmos o conjunto de fatores que se erguem em torno da recuperação do ex-cinema, um espaço intrinsecamente ligado a situações de apagamento de rituais e hábitos de cinema-going característicos de outras épocas. 
Estes lugares de memória são fundamentalmente vestígios do passado, as últimas encarnações de uma consciência da memória que sobrevive numa época histórica que não recorre à memória, pois a abandonou. Eles aparecem em virtude da desritualização de nosso mundo - produzindo, manifestando, estabelecendo, construindo, decretando e mantendo artificialmente e intencionalmente uma sociedade profundamente absorvida em sua própria transformação e renovação, que invariavelmente valoriza o novo em detrimento do antigo, o jovem em lugar do velho, o futuro em relação ao passado. Museus, arquivos, cemitérios e coleções, festas, aniversários, tratados, processos verbais, monumentos, santuários, associações, são os marcos testemunhas de uma outra era, das ilusões de eternidade. Daí os aspectos nostálgicos desses empreendimentos de piedade, patéticos e glaciais. São os rituais de uma sociedade sem ritual; sacralizações passageiras numa sociedade que dessacraliza; (...) Os lugares de memória nascem e vivem do sentimento que não há memória espontânea, que é preciso criar arquivos, que é preciso manter aniversários, organizar celebrações, pronunciar elogios fúnebres, notariar atas, porque essas operações não são naturais (NORA, 1984, p.12)

Acompanhando esse pensamento, é mister observarmos que os cinemas de rua em geral frequentemente desempenham o papel de marcos visuais, isto é, são elementos urbanos pontuais nas passagens das pessoas nas ruas. Além disso, funcionam como verdadeiras landmarks na elaboração das identidades locais e paisagens urbanas, a despeito do fenômeno transnacional de seu desaparecimento indiscriminado ocorrido em pequenas e grandes cidades durante os últimos 30, 35 anos. A imagem e o valor simbólico dos prédios que abrigaram cinemas se conservam nas histórias e nos afetos pessoais e na carne da cidade como um souvenir.

Embora faça parte de outro contexto de análise, lembramos a observação de Gilles Deleuze sobre o fato de que as cidades mantêm relações com a história das mídias (DELEUZE, 1992). A partir disso, sugerimos que as rupturas e continuidades transcorridas ao longo das épocas no cerne da cultura cinematográfica acompanham o próprio desenvolvimento de determinado local urbano, conectando-se a outras esferas da vida coletiva e das configurações citadinas. Se o equipamento cinema de rua, nos moldes em que se apresentou até o final do século $X X$, não reina mais como um ponto referencial urbano e opção de 
lazer soberana, é porque, claramente, as mídias, seus mercados e o acesso ao audiovisual cinematográfico encontraram outros suportes e caminhos; da mesma forma, os rituais de espectação cinematográfica - que, por sua vez, se conectam às práticas cotidianas efetivadas nos (novos) espaços - ganham outros arranjos. Quiçá por conta do impacto de todas essas transformações, uma onda de apreço pelo resgate de salas de cinema outrora marcantes torna-se, aqui e ali, a tônica de mobilizações da sociedade civil e instâncias governamentais, com ou sem o apoio do capital privado.

É este vigor da sala de cinema, como um dispositivo resistente e um "espaço do sonho" (VIEIRA e PEREIRA, 1982) atado fortemente às lembranças e aos universos afetivos das pessoas, aquilo que anima muitos projetos de reabertura, os quais se valem direta ou indiretamente da figura potente desses extintos/antigos movie theatres. Ao prefaciar o livro Ciné-Journal de Serge Daney, Deleuze (1992) coloca a questão da conservação de um suplemento, um souvenir que o cinema teria condições de criar. Por mais que Deleuze não se dirija neste texto aos equipamentos sala de cinema, mas à imagem cinematográfica, sua noção de souvenir torna-se pertinente para nós porque indica que o cinema, em todos os seus aspectos, tem a capacidade de preservar algo, uma centelha que pode ser ativada ou seguir em latência, a depender das circunstâncias.

Queremos justamente ir ao encontro desta dimensão suplementar que só o cinema seria capaz de preservar. Aliado ao meio urbano, o cinema, enquanto "equipamento coletivo de lazer", e a imagem cinematográfica, este "outro mundo" oferecido pelo ecrã, parecem se conservar de modo muito profundo nas reminiscências dos espectadores (FERRAZ, 2014). Mesmo quando são extirpados da paisagem onde estão incrustados, em algum grau, os cinemas e as ressonâncias dos filmes que exibiram mantêm laços com os indivíduos e comunidades, sustentam-se como pontos referenciais, ainda que imaginados, no sentido de que "Quando uma história, um sinal ou um significado vêm ligar-se a um objeto, aumenta o seu valor enquanto marco" (LYNCH, 
1999, p. 90).

As casas de exibição reabertas são elementos que fazem parte de uma rede mobilizada de memórias ligadas à fase de preponderância dos cinemas de rua entre os meios midiáticos de massa. Em um sentido próximo ao que Michael Pollak dá ao termo "memória enquadrada", como alternativa ao conceito de "memória coletiva", percebemos que a rede de memórias pessoais e grupais concernentes aos antigos cinemas é acionada e organizada segundo imperativos do presente.

A memória, essa operação coletiva dos acontecimentos e das interpretações do passado que se quer salvaguardar, se integra, como vimos, em tentativas mais ou menos conscientes de definir e de reforçar sentimentos de pertencimento e fronteiras sociais entre coletividades de tamanhos diferentes (...). É portanto absolutamente adequado falar, como Henry Rousso, em memória enquadrada, um termo mais específico do que memória coletiva. Quem diz 'enquadrada' diz 'trabalho de enquadramento'. Todo trabalho de enquadramento de uma memória de grupo tem limites, pois ela não pode ser construída arbitrariamente. Esse trabalho deve satisfazer a certas exigências de justificação (POLLAK, 1989, p. 9).

Investidores e entusiastas da reativação de equipamentos de exibição cinematográfica parecem manejar muito bem esse sentido. Remissões às eras de ouro de antigos cinemas, por exemplo, são dados que não deixam de fazer parte de um trabalho de enquadramento da memória. Assim, uma série de medidas são tomadas no tocante à recuperação desses locais segundo formatações e imperativos do presente, embora o passado cinematográfico nem sempre regresse com força entre as atividades dos novos espaços pós-reabertura. Esses são pontos que podem ser notados no caso do cine De Roma, que analisaremos a seguir.

\section{"More than just a cinema": o teatro popular De Roma}

Com base em dados coletados entre maio e novembro de 2015 ao longo de um trabalho de campo que contou com entrevistas e observação participante, além de informações obtidas em pesquisas 
em arquivos, cremos que o caso do cine De Roma, localizado no distrito do Borgerhout, na Antuérpia, região da Comunidade Flamenga belga, revela aspectos peculiares em relação aos usos instrumentais da memória e à intensa mobilização dos afetos de antigos frequentadores em prol da recuperação deste equipamento de lazer.

Inaugurado em 1928 por um imigrante italiano, o De Roma caracterizou-se desde cedo como um cinema de bairro e um centro de encontros para a população do distrito do Borgerhout. A força deste equipamento se deve a alguns fatos passados em relação aos laços criados com a população local, como, por exemplo, a decisão de JeanBaptiste Romeo, o fundador do De Roma, de ceder as instalações do cinema para que a própria comunidade do Borgerhout realizasse atividades culturais livres por lá uma vez por semana. Com espetáculos de palco e tela, o espaço teve uma importância capital para os lazeres locais, chegando a entrar na lista das poucas casas de exibição cinematográfica belgas autorizadas a funcionar durante a ocupação nazista, entre 1940 e 1945, desde que só exibissem produções alemães.

O De Roma foi também um cinema lançador. Apesar de ser distrital, praticamente restrito às dimensões urbanas de um bairro, e estando relativamente distante das zonas comerciais e do centro histórico/ turístico da Antuérpia, sua programação englobava lançamentos de fitas hollywoodianas sem atrasos em relação aos cinemas mais centrais. Isso passou a ocorrer principalmente a partir de 1953, quando a administração da casa ficou a cargo de Georges Heylen, um "barão" do mercado exibidor belga que integrou o De Roma ao seu vasto circuito de salas comerciais, o grupo Rex. Sessões de estreia de filmes estadunidenses como "When the Redskins Rode" (1951) e "The Clown" (1953), por exemplo, aparecem nos registros dos arquivos do De Roma como grandes sucessos da casa de exibição. Produções belgas "arrasaquarteirão" também foram exibidas pelo De Roma: as sessões do filme "De bruid zonder bed" (1955), de Edith Kiel, alcançaram um público de 11 mil pessoas neste cinema (DE ROMA, A UNIQUE..., p.6), cerca de $2 \%$ de toda a população da região da Antuérpia naquela fase. 
Porém, uma fase de baixas de público mudaria os rumos do De Roma. Durante uma densa transformação sociocultural ocorrida no distrito do Borgerhout ${ }^{5}$, a administração do De Roma precisou encontrar alternativas contra uma crise na bilheteria. A partir da década de 1960, o Borgerhout foi ocupado por imigrantes mulçumanos, essencialmente marroquinos, que imigraram para trabalhar na Antuérpia durante o período pós-Segunda Guerra Mundial (MUSLIMS IN ANTWERP, 2011, p. 18). Segundo Rob Gielen, atual assessor de comunicação do De Roma, devido às fortes diferenças dos hábitos culturais e de lazer dos grupos imigrantes, e também por causa da evasão das audiências belgas locais, houve uma expressiva queda na frequentação do equipamento ${ }^{6}$. Sobre isso, ele comenta:

\begin{abstract}
No começo dos anos 70, tivemos a combinação de dois fatores que provocaram o início da queda de visitantes. 0 primeiro foi o aparecimento da TV a cabo. Esse foi um fator importante para as pessoas não virem mais para o cinema e ficarem em casa. Outro fator, talvez mais importante, se deve à grande mudança demográfica do distrito. Ele costumava ser um espaço muito católico e jovem, mas durante os anos de crise, a população jovem migrou para o centro da Antuérpia. Assim, muitas casas foram colocadas à venda e ao mesmo tempo muitos imigrantes do Marrocos e da Turquia vieram morar no Borgerhout, principalmente marroquinos. Agora estamos em 2015, então, há 50 anos atrás o governo belga assinou um tratado com a Turquia e o Marrocos permitindo que os imigrantes viessem trabalhar aqui. Atualmente, 0 Borgerhout é o distrito mais denso em população e mistura de nacionalidades. Eles não têm ou não tinham a cultura de ir ao cinema. Eles não participam de atividades públicas de lazer. Esse tipo de atividade não concerne às suas próprias comunidades. Essa é uma diferença porque nós vamos a atividades coletivas de lazer e eles, não. Esses são os dois fatores, TV e transições demográficas, que contribuíram para o declínio do De Roma.
\end{abstract}

A sangria nas frequências fez com que o grupo Rex modificasse o tipo de atividade central operada no espaço. Contra um fechamento

\footnotetext{
5 O distrito do Borgerhout é composto por dois largos bairros, o Borgerhout Intramuros e o Borgerhout Extramuros, que possuem estruturas populacionais distintas. O primeiro concentra uma população de origem belga menor, sendo ocupado predominantemente por imigrantes mulçumanos, principalmente vindos do Marrocos. Há ainda turcos na composição populacional do bairro. O interessante é que por conta da característica fortemente marroquina do local, o Borgerhout ganhou a alcunha de Borgerocoo em referência ao vasto efetivo de cidadãos com raízes no Marrocos (MUSLIMS IN ANTWERP, 2011, p. 18). 6 Dados coletados durante entrevista com Rob Gielen em maio de 2015.
} 
imediato, o De Roma passou a funcionar como casa de shows e acabou se transformando em um os mais respeitáveis palcos da Bélgica por algum tempo. Artistas como Paul McCartney, James Brown e Iggy Pop chegaram a se apresentar no local. Entretanto, a falência não tardou muito a chegar e o equipamento cerrou definitivamente as portas em 1982. Foram 20 anos de abandono, com uma avassaladora deterioração da fachada e das estruturas internas do cinema, além de atos de vandalismo contra o prédio e itens deixados no seu interior como, por exemplo, os projetores, que foram destruídos ou saqueados.

Após o edifício ter sido comprado por um investidor privado em 1993 - que não teve interesse em reabrir o local para nenhuma atividade e o manteve em estado de degradação -, em 1997 um centro cultural do Borgerhout, o Rataplan, alugou o primeiro andar do prédio para a realização de pequenas atividades culturais em meio aos escombros. Em 2002, uma força-tarefa de voluntários começou a reconstruir o De Roma, retirando entulhos e fazendo os reparos do que ainda podia ser salvo. Em 2003, o cinema foi reinaugurado como um teatro popular, com capacidade para 2.000 pessoas.

A programação hoje é sortida e basicamente focada em shows musicais e peças de teatro, mas há sessões cinematográficas que acontecem pelo menos uma vez ao mês, dando preferência a filmes de arte e ensaio belgas ou estrangeiros. Além disso, o De Roma exerce uma considerável influência na agenda cultural da Antuérpia e se coloca como um equipamento bastante participativo na vida sociocultural e política do distrito do Borgerhout e da cidade como um todo.

Esta participação ativa do De Roma na comunidade se deve muito ao tipo de gestão do equipamento. O De Roma é um espaço gerenciado por uma associação sem fins lucrativos, que fora criada em 2002 justamente para dar suporte à reabertura do equipamento. Com $100 \%$ de controle da parte financeira das operações, a associação De Roma vzw é responsável pela administração dos aportes injetados pelos governos da província da Antuérpia (nível local), da cidade da Antuérpia, da Comunidade Flamenga, do distrito do Borgerhout, 
além das subvenções vindas do Fundo Europeu de Desenvolvimento Regional, que juntos representam $30 \%$ das receitas do equipamento.

Porém, não foram os recursos governamentais que aprovisionaram a fase inicial de reerguimento do De Roma. A retomada cultural do espaço só ocorreu devido à devoção de parte da população local do Borgerhout, admiradores do cinema e antigos frequentadores. Foram eles que, de forma voluntária, fizeram as primeiras restaurações do prédio do extinto cinema e, do mesmo modo, elaboraram o projeto de reativação. Até hoje, o trabalho voluntário no dia-a-dia do De Roma é um aspecto indispensável para a sua sobrevivência. Ao lado de um pequeno corpo de funcionários assalariados, os voluntários atuam em diversas frentes: no bar, na cozinha, na bilheteria, na limpeza, na organização do hall de entrada etc.

A rede de mobilização em prol do De Roma, para além do caso das ações de voluntariado e dos recursos públicos advindos das políticas culturais da região flamenga e administrações locais da Antuérpia, incluem ainda algumas medidas que possibilitam investimentos particulares no equipamento. Existe um menu de esponsorização à disposição de empresas e também de pessoas que admiram o trabalho realizado pelo De Roma. Qualquer indivíduo pode fazer doações diretas para o equipamento via website (nos valores de 5, 15, 25 e 35 euros) ou, por exemplo, adotar cadeiras em processo de restauro. O projeto do De Roma ainda oferece ao público, principalmente aos idosos que frequentavam o cinema no passado, um programa de inclusão do equipamento como beneficiário de testamentos.

A ideia de antigo cinema de bairro é aplicada em favor deste modelo atual do De Roma, que não se caracteriza mais como um cinema convencional. O seu passado como cinema de rua tornouse uma das fontes de recurso e justificativa para a conquista de entusiastas, voluntários e investidores de variados níveis. Baseado em narrativas sobre este passado cinematográfico (e o período como casa de shows), o projeto do De Roma construiu uma série de conceitos ligados aos esforços empregados em prol da recuperação/manutenção 
do espaço. É através do conceito de "Nós somos De Roma" ("We are De Roma") e do uso de palavras-chaves como "acreditar", "ter esperança", "sonhar" ("believe", "hoping" e "dreaming") (DE ROMA, A UNIQUE..., p.4) que se efetivam todas as ações da vida cultural do equipamento, a sensibilização do público e a renovação do prédio e seus elementos, levando em conta a sua inserção na cidade e na comunidade intercultural do Borgerhout:

Nós somos De Roma - Isto é um conceito, um trabalho de vida que nunca terá fim. Continuamos a trabalhar com o mesmo entusiasmo e a mesma devoção. Continuamos a acreditar, a ter esperança, a sonhar. Acreditando numa cidade habitável e agradável, onde as pessoas se encontrem e vivam experiências em comum. Tendo esperança de que o espírito positivo do De Roma encoraje iniciativas similares no Borgerhout. Sonhando que nós podemos estimular as pessoas a saírem de seu isolamento para aproveitarem uma performance no De Roma, no De Roma delas. Desejamos a cada pessoa um futuro cheio de respeito, compreensão e tolerância, mas também cheio de momentos de emoção no De Roma ou em outros de nossos teatros (...). Desejamos que todas as autoridades se disponham a dar uma chance justa a todos os tipos de cultura. Por fim, desejamos para nós mesmos um futuro brilhante com nada mais do que rostos felizes e sem problemas financeiros (DE ROMA, A UNIQUE..., p.4, tradução nossa).

As narrativas oficiais do De Roma engendradas em face de seu passado e de suas vocações contemporâneas vêm em socorro de um sentido preservacionista daquilo que já esteve à beira de um apagamento irremediável. Tzvetan Todorov fala a respeito desta interação entre o apagamento e a luta pela conservação do passado, relacionando essas expressões à noção de memória. "A memória não se opõe absolutamente ao esquecimento. Os dois termos contrastantes são o apagamento (o esquecimento) e a conservação; a memória é, sempre e necessariamente, uma interação entre os dois" (TODOROV, 2004, p.14). Em outro momento, Todorov também destaca que certos pontos de referência são capazes de estruturar a nossa memória, incluindo-a na memória coletiva da qual fazemos parte. Nessa análise, ele cita tanto Pierre Nora quanto Maurice Halbwachs quando descreve os marcos referenciais como monumentos, lugares de memória e 
instrumentos que reforçam a coesão social’ .

Posto isso, não podemos deixar de notar que as falas oficiais do De Roma se dirigem visivelmente a questões vinculadas à inserção do equipamento no Borgerhout e a operações de afirmação identitária fortemente ligadas a um passado de predominância belga/flamenga naquela região. Nesse ponto, é válido recorrermos em linhas gerais ao conceito de "memória manipulada" de Paul Ricoeur, cuja especificidade está situada "no cruzamento entre a problemática da memória e da identidade tanto coletiva como pessoal" (RICOEUR, 2004, p.80).

No seio da ideia de "memória manipulada" - que corresponde ao nível prático dos três tipos de usos e abusos da memória natural classificados pelo autor $^{8}$-, está a previsão de que existe um intenso trabalho das relações de poder em manipular memória e esquecimento. Este campo de forças é o lugar onde são engendrados alguns abusos da memória, criações de versões interessadas e autorizadas, seleções do que deve ser lembrado e do que deve ser esquecido. Nesse âmbito, Ricoeur salienta que é impossível separarmos memória e identidade, pois a mobilização da memória está a serviço dos apelos e demandas da identidade, o que, grosso modo, passa pela legitimação de determinados sistemas de poder e por circunscrições da memória de acordo com os traços identitários que definem determinada comunidade ( $p .85$ ).

Podemos, assim, inferir que a rede discursiva amparada por narrações sobre o passado histórico do De Roma como um antigo cinema de importância fundamental para a vida das pessoas e do Borgerhout participam deste jogo de lembrança-esquecimento e fomentam a produção de uma memória coletiva sobre o espaço. No entorno das

\footnotetext{
7 Pollak destaca a diferença entre a perspectiva de Halbwachs e a consideração que estudos construtivistas fazem acerca da memória coletiva. Para o autor, Halbwachs dá especial atenção à ideia de uma memória coletiva não coercitiva, capaz de unir os indivíduos em comunidades afetivas, apesar de reconhecer que há negociações entre a memória coletiva e as memórias individuais. Por outro lado, a perspectiva construtivista irá se interessar em como se constituem e se formalizam as memórias, quem são os atores e quais são os processos legitimadores que agem nessas construções. Esses trabalhos reconhecerão que há silenciamentos, seletividades e memórias que muitas vezes são apagadas em favor de uma memória hegemônica (POLLAK, 1989).

8 Ricoeur classifica três tipos de usos e abusos da memória natural: "memória impedida" (nível patológicoterapêutico), "memória manipulada" (nível prático) e "esquecimento de reserva" ou "memória obrigada" (nível ético-político) (RICOEUR, 2004, p.68-92).
} 
manifestações em prol de sua manutenção atual como teatro popular, também parece haver seleções estratégicas do que deve ser lembrado e em razão de quê. Por exemplo, a já mencionada questão do De Roma ter sido um dos únicos cinemas belgas a continuar funcionando durante a ocupação nazista, exibindo somente fitas alemães (cujas sessões no De Roma, de acordo com o assessor de comunicação do equipamento, Rob Gielen, obtinham boas audiências) é um dado pouco encontrado em meio ao material oficial organizado pela direção do projeto. Entre os usos estratégicos de sua representação como cinema e, decorrente desta memória como antigo cinema, há nuances e lacunas em relação a outros fatos, tais como a sua transição de cinema de bairro gerido por um grupo familiar para um espaço integrado ao império comercial do barão Georges Heylen.

As hipóteses que lançamos sobre o enquadramento estratégico da memória e a legitimação de determinadas versões do passado do De Roma se conectam ao que os autores ligados ao paradigma New Cinema History propõem sobre a história social da instituição cultural cinema. Segundo essa perspectiva, a história do cinema - pensado como uma instituição atravessada por uma miríade de vetores que não se limitam a questões cinematográficas propriamente ditas - lida com variadas ordens que passam por aspectos econômicos, o mercado de filmes em geral, estratégias corporativas de todos os tipos, mecanismos de censura e ainda com a micro história das práticas de ida ao cinema em níveis locais, o que, por sua vez, incluirá a história sociocultural das próprias audiências, seus padrões de gosto, orientações políticas, gênero, faixa etária, poder aquisitivo etc.

Se há determinadas formas de contar sobre o passado de um cinema em vista de interesses pontuais do presente, não há como negar que tais enquadramentos, manipulações e construções da memória dizem respeito a esferas associadas às formas locais de organização social, lazer, dinâmicas da política cultural, entre outros vetores. Esse argumento corresponde à expectativa da corrente New Cinema History de atrelar o campo do cinema ao que há de mais contextual, ou melhor, 
ao cotidiano e às miudezas que ingressam na experiência densa da ida ao cinema.

\section{Um espaço de exercício da memória: breves notas finais}

Devemos ter em mente que os anos de funcionamento do De Roma como cinema, antes de sua atividade como casa de espetáculos musicais, correspondem à outra estruturação sociocultural do Borgerhout. Conforme vimos, com a entrada das comunidades árabes na região, outros vetores identitários passaram o atravessar o distrito. Por mais que tenha havido um rompimento dos laços entre o cinema e as práticas de lazer locais durante os 20 anos de inatividade do equipamento, esse abismo não apagou definitivamente as reminiscências e os vestígios do De Roma. Ao contrário, foi desta espécie de "luto produtivo", da recusa em esquecer, que os atos pela sua recuperação se efetivaram.

Para Maurice Halbwachs (1992), a memória coletiva estará sempre ancorada em marcos espaciais que nos oferecem uma imagem de permanência e estabilidade. Hoje, o De Roma assume esta postura de lugar de memória em busca de uma estabilidade para as identidades e pertencimentos a ele vinculados, tal como seu projeto parece indicar:

\footnotetext{
Por que o De Roma causa tantas emoções mais do que outros espaços $(. .$.$) ? Porque ele é um 'espaço de memória' (...), um$ espaço que abraça a memória de várias gerações (...). Para as pessoas idosas, o De Roma é uma mera memória viva que de repente ressuscitou. Dezenas e dezenas de voluntários arregaçaram as mangas e alcançaram um sonho impossível. A restauração é um projeto fantástico concretizado pelas pessoas e isso é bastante singular. Após anos de frustração e infelicidade, todas as ruas em torno do De Roma levantaram e contribuíram para a reativação do De Roma. Noções como idealismo, pioneirismo e solidariedade ganharam um novo significado (DE ROMA, A UNIQUE..., p.2, tradução nossa).
}

Acreditamos que o caso do De Roma se vincula à noção de que a memória coletiva corresponde a formas de vida social que no passado marcaram os espaços urbanos e sobreviveram a mudanças, ganhando 
novos contornos e significados no presente (JODELET, 2010). Entre esses novos contornos, encontram-se mobilizações estratégicas em prol da manutenção do De Roma como um marco cultural regional e também aspectos que revelam o forte vínculo entre o equipamento e instâncias estatais.

O De Roma chega a ser considerado por alguns atores sociais como uma importante peça para as táticas de governamentalidade e influência política da Comunidade Flamenga belga e lideranças locais da Antuérpia no território. Recentemente, o equipamento esteve envolvido em embates políticos relativos à configuração das vias expressas que cortam a Antuérpia. Por ter cedido o seu espaço para a realização das reuniões do grupo que é a favor das obras de renovação do trânsito, as lideranças de um partido contrário, o separatista N-VA, acusaram o De Roma de ter se tornado um espaço policizado. Segundo o N-VA, o posicionamento político do De Roma em assuntos gerais da cidade contraria as suas finalidades como espaço cultural, cuja natureza deve ser neutra, já que o equipamento recebe recursos públicos advindos da administração pública (WYCKMANS, 2015). Contrariando este ponto de vista, conforme vimos, todo o processo de reativação do De Roma - que se mostra como um espaço de exercício da memória - envolveu desde o começo a sua acentuada participação no cenário sociopolítico e cultural do Borgerhout e, numa escala mais ampla, da Antuérpia.

Diante de todos esses aspectos, o caso belga do De Roma serve como um largo exemplo para que outros episódios de reabertura de cinemas possam ser examinados à luz do New Cinema History ou simplesmente por pesquisadores interessados em ir ao encalço das performances que tais equipamentos (em nada neutros) desempenham na configuração dos espaços das cidades relacionados às mídias, nos domínios sociocultural, político e econômico urbanos e na produção de sociabilidades, afetos e memórias dos indivíduos. Há de se levar em conta que as bordas do cinema, instituição social, são sempre porosas; mais ainda, é preciso perceber os projetos de reabertura ou reestruturação de históricas salas de cinema em vista das táticas de 
gestão das culturas urbanas locais e memórias das audiências, que, conforme o caso do De Roma demonstra, são suscitadas em prol de interesses e pautas fomentados por uma miríade agentes.

\section{Referências bibliográficas}

BILTEREYST, Daniël; MALTBY, Richard; MEERS, Philippe. Cinema, audiences and modernity: an introduction. In: BILTEREYST, Daniël; MALTBY, Richard; MEERS, Philippe (orgs.). Cinema, audiences and modernity: new perspectives on European cinema history. Oxon, New York: Routledge, 2012.

CENTRE DU CINÉMA ET DE L'AUDIOVISUEL. Bilan de la production 2014, Bélgica, 2015. Disponível em: http://www.audiovisuel.cfwb.be/index. php?id=avm_bilancca. Acesso em: 15 jul. 2015.

DE ROMA WEBSITE. Desenvolvido pelo teatro De Roma. Apresenta informações sobre o teatro. Disponível em: http://www.deroma.be . Acesso em: 15 jul.2015.

DE ROMA, A UNIQUE HISTORY. Antuérpia: De Roma, s/d, 10 p. Relatório técnico.

DELEUZE, Gilles. Conversações. Trad.: Peter Pál Pelbart. São Paulo: Editora 34, 1992.

FERRAZ, Talitha. A segunda Cinelândia carioca. Rio de Janeiro: Mórula, 2012.

- Espectação Cinematográfica no subúrbio carioca da Leopoldina: dos 'cinemas de estação' às experiências contemporâneas de exibição. 2014. 235f. Tese (Doutorado em Comunicação e Cultura) - Escola de Comunicação da UFRJ. Universidade Federal do Rio de Janeiro, Rio de Janeiro.

FOUCAULT, Michel. Space, knowledge and power. In: RABINOW, Paul (Ed.). The Foucault Reader. New York: Pantheon Books, 1984.

HALBWACHS, Maurice. A memória coletiva. São Paulo: Vértice, 1990.

JODELET, Denise. La memoria de los lugares urbanos. Alteridades, vol. 20, n. 39, jan-jun, 2010, pp. 81-89. Universidad Autónoma Metropolitana Iztapalapa, Distrito Federal, México. Disponível em: http://www.redalyc.org/ src/inicio/ArtPdfRed.jsp?iCve=74720828007. Acesso em: 3 out, 2015.

KUHN, Annette. An everyday magic: cinema and cultural memory. London: I.B. Tauris \& Co, 2002.

LYNCH, Kevin. A imagem da cidade. Trad.: Jefferson Luiz Camargo. São Paulo: Martins Fontes, 1999. 
LOTZE, Kathleen e MEERS, Philippe. 'They don't need me in heaven... There are no cinemas there, ye know': cinema culture in Antwerp (Belgium) and the empire of Georges Heylen, 1945-75. In: AVEYARD, K. e MORAN, A. (orgs.). Watching films: new perspectives on movie-going, exhibition and reception. Bristol; Chicago: Intelect, 2013.

MALTBY, Richard. New Cinema Histories. In: MALTBY, Richard; BILTEREYST, Daniël; MEERS, Philippe. Explorations in New Cinema History: approaches and case studies. Oxford: Blackwell Publishing, 2011.

MALTBY, Richard; BILTEREYST, Daniël; MEERS, Philippe. Explorations in new cinema history: approaches and case studies. Oxford: John Wiley \& Sons, 2011.

NORA, Pierre. Les lieux de mémoire. Paris: Gallimard, 1984.

MUSLIMS IN ANTWERP. At Home in Europe Project. London: Open Society Foundation, 2011.

POLLAK, Michael. Memória, esquecimento, silêncio. Estudos Históricos, Rio de Janeiro, v.2, n.3, p.3-15, 1989.

PORTAL BELGIUM.BE. Governo Federal da Bélgica, 2012. Apresenta dados sobre a Bélgica. Disponível em: http://www.belgium.be. Acesso em: 3 out. 2015.

RICOEUR, Paul. Memory, History, Forgetting. Trad.: Kathleen Blamey e David Pellauer. Chicago, London: The University Chicago Press, 2004.

STATISTICS BELGIUM. Cinémas. Bélgica, 2014. Disponível em: http:// statbel.fgov.be/fr/statistiques/chiffres/travailvie/temps/cinema/. Acesso em: 10 jul. 2015.

STEUN DE ROMA WEBSITE. Apresenta informações para os investidores do teatro De Roma. Disponível em: http://www.steunderoma.nu/ . Acesso em: 15 jul. 2015.

TODOROV, Tzvetan. Les abus de la mémoire. Paris: Arléa, 2004.

VIEIRA, João Luiz e PEREIRA, Margareth Campos da Silva. Espaços do sonho: arquitetura dos cinemas no Rio de Janeiro 1920-1950. Rio de Janeiro: Embrafilme, 1982.

WYCKMANS, Ferre. Subsidie Is Geen Zwijggeld - Cultuur Is Niet Neutraal, Ook Niet in De Roma. De Standaard, Antuérpia, 27 mar. 2015. Disponível em: http://www.standaard.be/cnt/dmf20150326_01600810. Acesso em: 30 mar. 2015. 


\title{
POR UMA POLÍTICA DA REMEMORAÇÃO: A POTÊNCIA HISTÓRICA NO CINEMA DE EXPERIÊNCIA PESSOAL
}

\author{
FOR A POLITICS OF MEMORY: \\ HISTORICAL POTENCY IN THE \\ PERSONAL EXPERIENCE CINEMA
}

Edição v.35 número 3 / 2016-17

Contracampo e-ISSN 2238-2577

Niterói (RJ), v. 35, n. 3

dez/2016-mar/2017

A Revista Contracampo é uma revista eletrônica do Programa de Pós-Graduação em Comunicação da Universidade Federal Fluminense e tem como objetivo contribuir para a reflexão crítica em torno do campo midiático, atuando como espaço de circulação da pesquisa e do pensamento acadêmico.

\section{ROBERTA OLIVEIRA VEIGA}

Doutora em Comunicação pela UFMG, professora adjunta do Departamento de Comunicação Social e do PPGCOM na mesma instituição. É editora da revista Devires - Cinema e Humanidades. Pesquisadora junto ao grupo Poéticas da Experiência (UFMG) onde desenvolve a pesquisa "O cinema de escrita pessoal: ensaio e documentário no cinema brasileiro contemporâneo". Membro do comitê consulto do Forumdoc.bh UFMG (Festival do Filme Documentário e Etnográfico). Brasil.

roveigadevolta@gmail.com

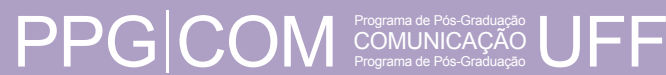

AO CITAR ESTE ARTIGO, UTILIZE A SEGUINTE REFERÊNCIA:

VEIGA, Roberta Oliveira. Por uma política da rememoração: a potência histórica no cinema de experiência pessoal. Contracampo, Niterói, v.35, n. 03, dez. 2016/ mar. 2017. 


\section{Resumo}

Pode o cinema de experiência pessoal cifrar a experiência histórica? Movidos por essa questão, na tentativa de descortinar uma política da rememoração, propomos apontar as potências subjetivas e coletivas do cinema de escrita de si, a partir das estratégias de evocação, constituição e figuração da memória. Um pequeno inventário de cineastas e filmes é proposto no sentido de identificar três figuras do cinema pessoal - o "eu-traço", o "devir-memória" e a "processualidade" - que articulam método e escritura de modo a fazer da obra uma tessitura temporal na qual a memória é tomada em sua relação inventiva com 0 esquecimento, e a história é concebida em suas formas fluídas.

\section{Palavras-chave}

política da cinema; rememoração;

pessoal

\section{Abstract}

How can personal filmmaking capture the historical experience? Having this question in mind, and aiming at revealing a certain politics of remembering, I set off the collective and subjective potency of self-filmmaking that emerges from various strategies for evoking, constituting and depicting memory. A short inventory of Brazilian films and filmmakers is sketched in order to guide the identification of three figures of selffilmmaking - "self-trace", "becomingmemory", and "processuality" - that articulate together a method and a filmic writing that engenders a temporal texture in which memory stands in a creative relation to forgetfulness and history takes a fluid shape.

\section{Keywords}

politics of remembering; cinema; personal experience 


\section{Potência da rememoração}

Aquém da história pensada sobre os grandes fatos, aquém da politica pensada através das grandes questões, é possível dizer que a potência coletiva do cinema de experiência pessoal ${ }^{1}$ - voltado ao espaço do próximo (o íntimo, a casa), e às recordações familiares e subjetivas - reside numa política da rememoração que torna a escrita de si ensejo para religar a memória a sua natureza processual e reinscrevê-la no presente. Em sua recusa em oferecer-se congelado e pronto a ser acessado, o passado só pode surgir na relação com o presente que o ativa no ato mesmo da escritura cinematográfica. Nessa medida, ao contrário de pensar a memória como inerte, apartada do cotidiano, a ser resgatada por um movimento histórico de preservação e reconstrução do passado, o cinema de experiência pessoal permitiria ao sujeito habitar a memória sem consagrar-Ihe um lugar específico, bem à maneira desejada por Pierre Nora (1993, p. 7-28). ${ }^{2}$ A memória, para qual esse cinema é capaz de se por a trabalhar, nasce das múltiplas possibilidades de evocação e invenção que "o estar diante do" esquecimento, no ato do fazer fílmico, gera, portanto é, como queria Benjamin, imanente e infinita. A política da rememoração aparece na medida em que a dimensão subjetiva do cinema pode nos ensinar - a

\footnotetext{
1 A nomeclatura "cinema de experiência pessoal" pretende marcar a diferença desse cinema documental voltado, como diria Michael Renov, a uma "etnografia doméstica" (2004, p. 13) em relação ao enfoque e à forma de escritura, portanto, ao método, do cinema documental que se realiza sobre o outro, em espaços fora do doméstico. Concordamos com Michael Renov (2004) de que ambos documentários - esses que se dedicam ao espaço do próximo e esse que se põe a olhar outros espaços, sujeitos e comunidades podem ser mais ou menos ensaísticos, e se interceptam. Porém, ao apontar a diferença de inscrição ou circunscrição, estamos longe de conceber o cinema de experiência pessoal como subjetivista ou solipsista, ao contrário. Na esteira de Renov, nos interessa pensar a potência desse cinema de si em seus modos de convocação do outro, da alteridade, da diferença e, portanto, do coletivo. Para além dos ensaios cinematográficos, em que, ao olhar a experiência do outro, o sujeito se escreve, como por exemplo, o cinema de Chris Marker, ou Trinh T. Minh-há, no belo Reassemblage, trata-se, antes de tudo, de uma premissa: a impossibilidade de dizer de si fora da teia da linguagem que se constitui no que é exterior ao "si mesmo".

2 Para Pierre Nora vivemos um momento particular na contemporaneidade onde a consciência da ruptura com o passado se confunde com o sentimento de uma memoria esfacelada, porém, no qual, o esfacelamento desperta ainda memória suficiente para que se possa colocar o problema de sua encarnação. Ou seja: há locais de memória porque não há mais meios de memória. É porque não habitamos mais nossa memória que temos necessidade de consagrá-la lugares "os lugares de memória nascem e vivem do sentimento que não há memória espontânea, que é preciso criar arquivos, que é preciso manter aniversários (...), notariar atas, porque essas operações não são naturais. (...) Se vivêssemos verdadeiramente as lembranças que eles envolvem, eles seriam inúteis. E se, em compensação, a história não se apoderasse deles para (...) petrificá-los eles não se tornariam lugares de memória" (NORA, 1993, p. 13). A memória enquanto um evento sempre atual, um elo vivido no eterno presente, é subtraída pela história em seu afã de reconstrução do passado.
} 
partir de sua lida aberta e sempre renovada com o passado (porque cravada no terreno da experiência particular, vivida no corpo e no gesto de escritura que a conforma) -, sobre um inconsciente da história.

\begin{abstract}
Mas é o preço a se pagar pela "revolução copérnica" da história: levar em conta os processos da memória, logo, do inconsciente e da imagem, obriga a um deslocamento radical da razão na história hegeliana. Não é mais o fio do Espirito absoluto, mas às mechas desfiadas de imagens muito relativas que se constrói e se desconstrói a historicidade. Não é mais em nome da eterna presença da Ideia, mas em nome de frágeis sobrevivências - psíquicas ou imateriais que o passado deve ser 'atual'. Não é mais o universal que se realiza no particular, mas o particular que, sem síntese definitiva, dissemina-se por toda parte. (DIDI-HUBERMAN, 2015, p. 130)
\end{abstract}

Para Benjamin, via Didi-Huberman, o historiador "é um arqueólogo do inconsciente da história" (2015: 123), e só pode sê-lo na medida em que, na contramão do historicismo (em sua concepção continuísta da relação passado e presente), reconhece que não existe história sem uma teoria da memória, e que a mesma tem uma dupla inscrição: material e psíquica. A material é essa que nos vm pelos vestígios, está nos objetos do passado que restam no cotidiano, e a psíquica traz o ritmo dos sonhos, dos sintomas ou fantasma, dos recalques e seus retornos, das latências e crises. "Diante disso, o historiador deve renunciar a outras hierarquias - fatos objetivos contra fatos subjetivos - e adotar a escuta flutuante do psicanalista atento às redes de detalhes, as tramas sensíveis formadas pelas relações entre as coisas" (DIDI-HUBERMAN, 2015, p. 117). Como insiste DidiHuberman, não se trata de puro subjetivismo, ou do surrealismo em si, mas atentar para o inconsciente da história é a possibilidade de escrevê-la a contrapelo tanto epistemologicamente falando, no sentido de contrariar a concepção historicista, racional e linear, quanto no sentido de dar a ver a história dos sujeitos ordinários, principalmente, daqueles que foram apagados, vencidos, no processo de hierarquização dos valores históricos. É nessa dimensão, da experiência encarnada no vivido, e elaborada pelo sujeito que viveu, que o cinema de escrita de si reivindicaria para a história não só o lado material, dos vestígios 
inscritos nos arquivos, mas, principalmente, o lado psíquico. Ao lado psíquico cabe ainda atualizar a necessária relação subjetiva com a história ao restituir em seus métodos, recursos e figuras, a porosidade da memória, sua força inventiva e imaginativa, colocando a relação do passado com o presente no processo e na escritura fílmica (montagem) e não numa suposta identificação entre eles.

Porém sabemos que essa politica da rememoração que existe em potência no cinema de experiência pessoal, nada valerá caso o cineasta se renda a autobiografia construída fora do processo mnemônico, fora de sua relação dialética, vital e criadora, entre a lembrança e o esquecimento, e tome o passado como história linear a ser reconstituída, enfim, caso abdique de engajar a expressão da própria vida no fazer presente da escritura cinematográfica. Nesses termos, para pensar a potência da rememoração em ato, precisamos ir aos filmes e indagálos sobre quais recursos, métodos, figuras, a escrita de si lança mão para se lançar ao trabalho da memória, esse que, à maneira de Proust, e contrária à história hegemônica, não descreveria "... uma vida como ela foi, e sim uma vida lembrada por quem a viveu" (BEMJAMIN, 1994, p. 37). São três as figuras de escritura que nos parecem fundante da politica da rememoração no que ela concerne à relação história e memoria: o eu-traço; o devir-memória e a processualidade.

\section{Figuras da escrita de si}

O eu-traço, o devir-memória e a processualidade são figuras que nos permitem olhar para os filmes de pelo menos dois pontos de vista fundantes da experiência com a memória no cinema de escrita de si. Num primeiro ponto de vista, o cinema de experiência pessoal é tomado a partir do dispositivo que conforma o filme, portanto, a atenção se volta às estratégias documentais das quais se vale o cineasta: as formas do antecampo (a posição da câmera e do cineasta em cena bem como suas formas de interação) e a mise-en-scène do mesmo e dos personagens. Nesse campo, está em jogo tanto uma visada reflexiva, a relação com o próprio cinema, quanto coletiva: o modo como o 
cineasta se aproxima de si mesmo e do outro, o modo como se deixar ser ou não atravessado pela alteridade que pode arrastá-lo do centro narrativo revelando à abertura e à multiplicidade do si e o dialogismo da linguagem. O outro aqui é tanto um outrem, um outro em si (sujeitos no mundo e o próprio mundo), quanto o outro de si, o eu-traço que emerge nessa situação "entre" que a escrita pessoal pode evocar ao colocar-se no limiar, entre o esquecer e o lembrar, o outrora e o agora, que seria, segundo Bejamin, o intervalo da dobra dialética, um estado de saber-ainda-não-consciente que, para o autor, caracteriza o tempo do acordar, um tempo entre o sonho e a vigília. ${ }^{3}$ No segundo ponto de vista, o cinema é tomado em sua lógica formal, concernente ao agenciamento das relações entre as imagens, que se manifesta mais enfaticamente no modo como os arquivos enquanto vestígios, restos do vivido, são montados, possibilitando uma perspectiva, digamos, epistemológica, para se pensar, através da escritura que reinventa a memória na relação com as imagens e entre elas, o próprio pensamento histórico e político.

É correto afirmar que quando falamos do cinema de experiência pessoal nos aproximamos da seara dos gêneros de escrita de si (confessionais), como a autobiografia, o memorial, o diário, tão largamente estudados pela teoria literária. Na teoria literária, o gesto autobiográfico tem como premissa a referencialidade do sujeito, a homonímia entre autor, personagem, narrador que conduz ao que Philippe Lejeune chamou de pacto autobiográfico: a confiança do leitor de estar frente a um relato sincero, daquele que viveu, sobre si mesmo. Se esse pacto na literatura já foi bastante complexificado e combatido - entre vários autores de referência, pensemos, por exemplo, em Paul De Man, que defende a inexistência de um ente fora do texto no próprio

\footnotetext{
3 Aqui nos referimos à leitura que Didi-Huberman faz de Benjamin para quem cada época histórica não é só um espaço de tempo, mas o sonho de um tempo que coloca a história além de fatos e ações supostamente ocorridas, pois inclui uma metapsicologia do tempo: "Metapsicologia apoiada em uma leitura atenta da psicanálise freudiana, mas também na exploração constante da Recherche (Em busca do tempo perdido) proustiana. Benjamin, nesse terreno fundamental, deixa para trás certos materialistas que, na esteira de Marx, veriam no conhecimento meramente um ato de despertar (éveil) (somente a recusa do sonho) e certos surrealistas que, na esteira de Yung, veriam no conhecimento meramente ume estado de sonho. O momento de "conhecimentabilidade" histórica surge como uma dobradura dialética: constitui-se na dobra do sonho e do despertar, ou seja, no instante biface do acordar (réveil)", (2013, p. 125).
} 
texto, ou, em Serge Doubrovsky, ${ }^{4}$ que insiste na dimensão artificial da escrita autobiográfica -, no cinema, principalmente no Brasil, essa discussão ainda pode ser revista e aprofundada. No cinema, tendo em vista a inscrição indicial que a imagem implica, o eu referencial ganha um outro estatuto uma vez que o sujeito aparece na cena. Eis a torção que o cinema opera: uma vez que o sujeito está na imagem, a referencialidade parece inconteste. Além disso, o cinema de experiência pessoal também se vale das estratégias e do contrato assegurado pelo gênero documentário, no sentido de asseverar ainda mais a verdade da vida narrada. Nesse sentido, o apelo à narrativa linear e cronológica que, como diria Doubrovsky (2914, p. 123), cria a impressão de desnudamento da lógica interna de uma vida, tem dupla função negativa: fazer crer na ilusão de que o sujeito possui uma identidade fixa e sempre a mesma, da qual tem natural consciência; e fazer crer na ilusão cinematográfica de que o cinema é uma representação fiel da realidade. Tanto sujeito quanto cinema perdem seus atributos de artifício linguageiro, de se forjarem no exercício do mesmo de sua função ética e estética. É essa dimensão da autobiografia pensada como espaço da verdade sobre si que conduz a uma apropriação equivocada da memória. Se o sujeito só escreve porque lembra há de se pensar, junto com Doubrovsky, o lado encoberto dessa rememoração que nunca se oferece inteira, e, portanto, o quanto "as lembranças são histórias que contamos a nós mesmos" (2014, p. 122). O sujeito não pode ser, portanto, como já descaracterizado por Freud, concebido como aquele que tem acesso a seu eu mais profundo, e, por isso, capaz de externalizá-lo na forma de uma narrativa cinematográfica, mas aquele cuja existência, ainda que amparada na referencialidade indicial, só se verifica na relação com outro - seja o outro com quem compartilha a experiência do fazer cinematográfico no documentário em primeira pessoa, seja o outro de si mesmo, o eu-traço, que sobrevém, como já dito, no estado intermitente do acordar que, no processo cinematográfico, reside no

4 Sobre esse debate de Philippe Lejeune, Paul De Man e Serge Doubrovsky em torno autobiografia conferir, NORONHA (org), 2014. 
ato mesmo de transformar-se em imagem e, portanto, de colocar-se em obra. É nessa medida que a figura do eu-traço aponta para a forma como o fazer documentário permite ao sujeito lançar sua memória para fora, ou seja, constitui-la em ato, nas relações que o filme permite travar com o outro, o próximo, o cotidiano, o mundo que ele ao filmar coloca a distancia. ${ }^{5}$

Apesar do estatuto de recriação subjetiva que o ato de transformase em imagem carrega, em sua capacidade de inscrição verdadeira, o cinema ganha um estatuto de prova, de algo que de fato aconteceu e foi filmado, a partir do qual a imagem guardada seria testemunho inquestionável de um passado inacessível, portanto o registro da memória enquanto substância preservada. Nesse sentido, o cinema acrescentaria outra camada de ilusão (fortemente ancorada na ilusão historicista) a partir da qual a memória é novamente apropriada sob o signo do registro fixo e acabado de histórias que se conectam ao longo da vida, as quais o sujeito pode acionar e se fazer valer para escrever sua própria biografia. O cinema viria, desse modo, com seu poder indicial, (re)mitificar o que a teoria da literatura, a filosofia da memória, e o inconsciente histórico de Benjamin, tentou desmistificar. Por outro lado, se a imagem é prova, ela é também ausência, ou seja, uma presença ausente na qual a referencialidade do sujeito na imagem se constitui na mesma medida em que a certeza de que ele não está mais lá (o que para a literatura não é tão simples). Se o sujeito não está lá na imagem, é porque essa como signo só pode apontar para um isso foi. Enfim, ela mesma aponta para uma memória enquanto traço do que já não é mais. Estando o cinema, ele mesmo, no espaço da memória, resta ao cineasta, que ainda pretende responder ao pacto autobiográfico, fazer crer na ilusão cinematográfica buscando as formulas prontas de promover o encadeamento narrativo, ou se

\footnotetext{
5 Aqui, vale a pena lembrar novamente a discussão de Michael Renov que, além de pensar o documentário de experiência pessoal como possibilidade de contradiscurso de uma minoria ou coletivo, no qual o sujeito se inscreve, em sua inspiração lacaniana, enfatiza a dependência da subjetividade ao campo do outro, para alcançar, em seguida uma definição, baseada em Derrida, que nos parece próxima à dimensão da politica da rememoração que nos interessa: a de um cinema que "mobiliza o sentido num limite dinâmico entre o trabalho e a vida, o sistema e o sujeito do sistema" (RENOV, 2004: 105).
} 
instalar na dobra dialética, no estado análogo ao acordar, no qual o mecanismo da memória como esquecimento, e invenção presente no filme, permite que o espectador venha se instalar no entre imagens, no intervalo que recria a existência em sua intermitência e temporalidade complexa, desvelando o mito da história unificadora e hegemônica.

Daí a importância de que a soberania da história (que não deixa de ser uma soberania do sujeito) dê lugar ao cinema como invenção, no sentido de uma práxis que não nega a força de evocação vestigial das imagens (arquivos ou não), mas reconhece sua existência incorporada no filme como um processo. Não há filme de toda uma vida, portanto não há arquivo como repositório capaz de cobrir uma existência. As imagens e os arquivos são sempre incompletos e sempre esperando uma montagem futura, como já disse Didi-Huberman em sua leitura de Benjamin (2015, p. 133). No cinema essa montagem futura está no presente do fazer cinematográfico e no presente das assistências ao filme. Se o arquivo é passado, ele não existe guardado na gaveta, ele existe quando ressurge e ao ressurgir recria o que foi num arranjo possível. Nesse sentido a memória pode surgir como invenção, e o cinema como devir memoria. Se o devir-memória, diz respeito à possibilidade da própria escritura fílmica se dar ela mesma como um tecido mnemônico lacunar, e dessa forma apontar para uma concepção da memória que deveria ser fundante de um modo de pensar histórico, a processualidade está mais próxima ao sujeito que toma o cinema como um modo de se colocar em obra fazendo da relação com o mesmo uma forma de vida. E é nessa relação processual e inacabada do sujeito com a própria vida, no fazer cinema, que o eu-traço surge como já não mais um si, mas um sempre outro, já não mais um passado, mas um sempre tornar-se.

Se as figuras se perpassam e se interceptam, é porque a alteridade do eu-traço, o devir, e o processo, são conceitos que remetem a memoria não como fixa, mas em sua dimensão atual, inventiva, mutante e (re) signifcante da experiência vivida e da elaboração de si, que juntas apontam para a possibilidade de constituição do político no âmbito do 
pessoal.

\section{O eu-traço}

No domínio da escrita de si, muitos filmes se utilizam de uma narrativa tradicional e cronológica que busca resgatar o passado como uma continuidade linear, e assim criar uma identidade coesa, a ilusão da igualdade entre ser, viver e parecer. Em vários deles o eu se inscreve de forma bastante inflacionada. Em perspectiva oposta, há filmes que se encaminham em direção a formas ensaísticas nos quais o passado é percebido como perdido e a memória, feita na aliança entre lembrança e esquecimento, impulso para criação narrativa no presente da obra, assim como o próprio eu, que só pode surgir como experimento das formas cinematográficas e, portanto, como também em obra. Nesses documentários ensaísticos, o cineasta não tem controle sobre o efeito de si que a escritura fílmica gera, portanto, se apresenta em sua condição de sujeito não-inteiro, e assim, bem como a memória, se institui menos como resgate da coisa originária do que como invenção que a rasura e a deforma. Ou, como diria Lucia Castello Branco, o sujeito da autobiografia, assim como o passado que evoca, é feito um fragmento do perdido, isto é, o rastro, ou o traço de uma instância imagética e narrativa.

Enquanto sujeito de memória, este é seu insano ofício, sua absurda tarefa: tecer, com a urdidura do esquecimento, a trama da lembrança; traçar, com os riscos de uma escrita apagada pelo tempo, as letras de uma nova escrita, que o levará a uma outra história, a um outro tempo, a um outro lugar. Inscrito nesse absurdo projeto de captura/invenção do vivido, o sujeito inventará a si próprio como sujeito de linguagem, como sujeito de memória. Também ele se reduzirá a um traço, a um signo virtual (ou um significante vazio, na acepção lacaniana), a ser apenas precária e momentaneamente preenchido na instância discursiva. (CASTELLO BRANCO, 1994, p. 75)

Para pensar as possibilidades do cinema de experiência pessoal de se aproximar do efeito eu-traço e se distanciar do planejamento prévio da narrativa que opera com o passado enquanto dado fixo a se resgatar e com a memória enquanto uma trilha linear de lembranças 
a ser preenchida, tratemos de três filmes brasileiros recentes que aqui denominamos autobiografias não-autorizadas, no qual o relato autobiográfico não é impulso da obra, mas sim a biografia de outro: Diário de uma Busca, de Flávia Castro (2010); Mataram meu irmão, de Cristiano Burlan (2013); Os dias com ele, de Maria Clara Escobar (2012). Nos dois primeiros filmes ${ }^{6}$, os cineastas realizam um trabalho de elaboração da morte de seu parente próximo, de modo que o processo de filmagem seja uma experiência no presente sobre outra, passada. Tais filmes são biografias não autorizadas - uma vez que os parentes mortos não poderiam autorizar o filme de suas vidas - que engendram autobiografias não-autorizadas, na medida em que a história do próprio cineasta surge indiretamente, pela via desse outro (o pai de Flávia e o irmão de Cristiano) e que, portanto, são potencialmente afeitos em ensejar um mecanismo mnemônico que aciona o eu-traço. O quarto filme Os dias com ele, apesar de se tratar da relação com o pai vivo, e por isso não constituir de saída uma biografia não-autorizada, constitui um autobiografia não-autorizada nessa medida em que é feita a partir da história de outro, e que esse outro, o pai da cineasta, resiste também, na própria cena do filme, a autorizar (no sentido de corroborar) com o projeto de filme que a filha procura.

Ao contrário da biografia, a autobiografia não autorizada abre a possibilidade do sujeito - mesmo sendo enunciador e enunciado, diretor e personagem do próprio filme - não ter controle ou plena consciência do eu que está se construindo. Dessa maneira, o autorizarse não se refere ao âmbito legal - o sujeito que autoriza que seja feita sua biografia - mas ao fazer estético e político: aquele que filma potencialmente se inscreve numa narrativa cinematográfica de forma porosa e lacunar, produzindo um eu aberto e plural, por, a princípio, não partir de uma identidade idealizada ou de memórias pré-determinadas, mas do desejo de busca pelo outro, e de construção do outro. Tratase de pensar, junto com Paul De Man (apud CATELLI, 2007, p. 227),

6 Para uma perspectiva mais analítica desses três filmes, cf. VEIGA, 2014. 
que o eu da obra é sempre um intervalo, um vazio deformado, que se instala entre o sujeito que filma e a máscara que ele mesmo constrói ao se inscrever.

Ao contrário do controle de si numa narrativa pré-determinada, em que a memória é tomada como arquivos-lembrança selecionados de forma a limpar a história do sujeito de ambiguidades, incertezas e oscilações, a não- autorização permite essa deformação que o eutraço produz na forma fílmica ela mesma. Assim, o aparato cinema pode se dar a ver em sua fragilidade e limitação, atestando junto com a impossibilidade de resgatar o passado que já se foi, a impossibilidade de se partir de um eu completo e fixo. Se o eu não é uma visada intencional do sujeito que se inscreve mais chances haverá que ele surja como um eu-traço, um efeito do ato de se por em obra no processo de construção fílmica.

Em geral, os documentários (auto)biográficos lançam mão de algumas estratégias comum a fim de lidar com o passado e figurar a memória para reconstruir uma vida: o uso de arquivos domésticos e institucionais (fotos, vídeos, gravações, cartas); as reencenações - a encenação ficcional de situações vividas; as revisitas, ou seja a volta aos lugares - cidades, casas, instituições - onde o relatado viveu ou frequentou; a narração em off, e as entrevistas e testemunhos. Diário de uma busca possui todas essas estratégias dispostas de forma a reconstruir numa ordem cronológica a vida de Celso Castro, o pai de Flávia, um militante de esquerda que foi morto em situação estranha na casa de um nazista. Apesar da linearidade narrativa, do domínio e da orientação da narração em off da cineasta, em primeira pessoa, em Diário de uma busca as revisitas aos lugares onde Celso esteve enseja encontros inusitados e interações que levam Flávia, a sair da personagem que o off institui para se elaborar em ato, deslocando a dimensão mais roteirizada do filme que se abre ao risco do real, e faz do passado um fluxo aberto à atualização presente e da memória uma invenção que o processo fílmico engendra. Em algumas entrevistas, a força do encontro, recoloca a cineasta que, ao aparecer no antecampo 
convocada pelo olhar e a fala de um outro, escapa ao controle narrativo. Além disso, Flávia mesmo com um material de arquivo bastante robusto, imiscui entre imagens-vestígios (fotos em sua maioria) - que remetem a momentos específicos da vida de Celso - imagens-auráticas que se caracterizam pela evocação da memória como esquecimento, operando na presença da ausência, na impossibilidade do rastro reconstituir uma origem, mas apenas evocar o passado pelo vazio que resta ali: no lençol a balançar no varal, nos soldadinhos de chumbo enfileirados na janela, ou na gangorra que balança solitária num parquinho. Por vezes desfocadas, outras paradas, elas duram e se abrem a memória num gesto menos direto que remete ao passado inatingível de uma vida qualquer e comum, e se diferem dos arquivos-lembrança, fotos cuja inscrição indicial remete diretamente a uma vida de experiência qualificada. Por fim, há uma tensão entre Flávia criança e a vida adulta do pai - a política, o exílio - que através desses personagens cria certos atritos, ranhuras, no deslizamento da narrativa.

Já em Mataram meu irmão, diferente de Diário de uma busca, os mecanismos cinematográficos usuais de figuração da memória são evitados e até em certa medida contrariados em sua função. O off em primeira pessoa ocupa apenas uma introdução do filme, quando Cristiano fala de sua dor diante da notícia da morte de seu irmão Rafael a tiros no Capão Redondo, periferia de São Paulo. Praticamente não são usados arquivos domésticos (vídeos ou fotos) que acionem o passado da família, a infância dos irmãos, ou até mesmo a vida de Rafael, seus filhos e esposa. Há apenas uma foto amarelada e rasurada de três crianças (que parecem ser Rafael, Cristiano e outro irmão), e as fotos de identificação do arquivo policial que mostram Rafael já baleado em várias posições. Ao sonegar o acesso à imagem de Rafael vivo, aos vestígios de sua vida em situações alegres ou mesmo comuns, o filme recusa que o tecido mnemônico se construa por imagens indiciais e assim recusa ainda a possibilidade de resgate do passado, como se fosse impossível ao cinema voltar no tempo, como se ele mesmo, o cineasta, não se fiasse nessa possibilidade mágica do aparato: de dar 
vida aos mortos. Mesmo esses poucos arquivos a que se tem acesso - a imagem velha e rasurada e as fotos do irmão já morto - são incapazes de remeter ao tempo de vida e assinalam apenas o tempo de morte que contamina todo o acontecimento do filme que se condensa num presente contínuo. Essa dureza na lida com o cinema revela um importante traço documental - o uso constante das entrevistas, da interação do cineasta com aqueles que constituem um história comum do Capão redondo, aquela da qual Rafael faz parte. Desse modo, a figura de Cristino é acionada apenas através do antecampo de forma indireta, instituindo um eu opaco que surge como um traço no discurso dos parentes e amigos próximos, ou como mais um personagem de uma tragédia familiar quando o antecampo é atravessado pelos sobrinhos do cineasta que chorando num momento de saudade 0 abraçam. Ainda que os testemunhos evoquem imagens de Rafael e da família no passado, em sua maioria, circundam o episódio da morte e a dor da ausência, tornando as lembranças por demais esparsas para refazer um passado comum, e os episódios felizes por demais frágeis para restituir vida ao morto. Rafael paira como um fantasma de forma que a memória se mantém tensionada por todo o filme. Esse confinamento do filme no presente de sua realização faz emergir algo bem mais coletivo, a precariedade dos vestígios e a impossibilidade de ver e saber tudo sobre Rafael cuja imagem só se esboça polifônica e dialogicamente (nos atos de fala das entrevistas), inscrevem os testemunhos num presente trágico comum da periferia de São Paulo, onde, como a memória, vidas são apagadas e o futuro não se coloca. Se o passado só pode se esgueirar aos cacos, a memória só irá surgir em lampejos, na tensão da falta.

Assim como em Mataram meu irmão, no terceiro filme citado, Os Dias com ele, a cineasta também aparece na imagem a partir do antecampo, através da lida com outro, da interação com o pai vivo que se posta diante da filha que o filma. Porém, Maria Clara Escobar aparece com mais frequência e força que Cristiano e Flávia. Nas conversas com o pai, ela está sempre a um passo de atravessar o antecampo e, algumas 
vezes, o faz. Sua voz é uma constante na cena, ainda que fora dela, e, em off , ela recobre poucas imagens de arquivo que surgem na tela. Porém, sabemos que tais fotos não são pessoais, mas perfazem um álbum qualquer de uma família em situações comuns. Por meio dessa estratégia formal, a cineasta não apenas aponta o lugar da falta, do vazio, a ausência de lembranças da infância com pai, a ausência de uma memoria comum a ambos, mas também a dimensão artificial, o engodo do dispositivo cinema, capaz de, ao construir um imaginário simbólico comum (através de momentos alegres de família), forjar uma memória sempre a mesma, rastro que, como tal, nunca reencontra a origem. ${ }^{7} \mathrm{~A}$ memória se faz traço e com ela o sujeito da memória. Mesmo quando reconstituída nos atos de fala que sustentam a longa entrevista nos dias que Maria Clara passa na casa do pai, ela vem em fiapos, permeada de lacunas, de recusa à lembrança, seja pela surdez, pelo silêncio, ou pelos desvios. Nessa conversa infinita, por meio do qual a filha procura saber do pai como foi sua experiência de tortura durante a ditadura, e também pelas pistas de suas relações familiares, principalmente com ela própria, o passado não poderá nunca se oferecer como um dado passível de ser cronologizado pela narrativa. Ele surge como fragmentos de um objeto inalcançável através dos questionamentos descosturados que a filha cineasta lança ao pai, sujeito filmado, e dos quais o pai sempre se esquiva, sempre desvia, e sempre devolve a ela na forma de recusas, de incompreensões, e de outras questões sobre a feitura do filme, o planejamento e o método, criando assim um campo de disputa pela direção do filme e de conflitos, sempre tenso e oscilante. Maria Clara se esboça ao mesmo tempo firme e fragilmente, nessas idas e vindas, nas tentativas de precisar melhor seu projeto de filme para o pai, e de qualificar suas questões, transformando o que seria uma

7 O rastro não e somente a desaparição de origem, ele quer dizer aqui - no discurso que proferimos e segundo o percurso que seguimos - que a origem não desapareceu sequer, que ela jamais foi reconstituída a não ser por uma não-origem, o rastro, que se torna, assim, a origem da origem. Desde então, para arrancar o conceito de rastro do esquema clássico que o faria derivar de um não-rastro originário e que dele faria uma marca empírica, é mais do que necessário falar de rastro originário ou de aqui-rastro. E, no entanto, sabemos que este conceito destrói seu nome e que, se tudo começa pelo rastro acima de tudo não há rastro originário. (DERRIDA, 1973, p. 75) 
autobiografia indireta numa dobra menos sobre si mesma do que sobre o fazer cinematográfico que está em jogo naquele presente duradouro da conversa com o pai. O pai que nunca autoriza completamente 0 relato de si e a filha que se reinventa na necessidade de obter essa autorização. Trata-se, portanto, de um filme que com o pretexto de voltar ao passado, de acessar as memórias do pai pra dizer de sua vida, acaba por se tornar o embate presente apanhando na auto miseen-scène de ambos, onde os personagens se constroem pra obra e na obra.

\section{O devir-memória}

Poderíamos dizer que Diário de uma busca, sem perder a força processual, é mais memorialistas (do ponto de vista de um resgate do passado) e que Mataram meu irmão e Os dias com ele se revelam na força do presente da obra e, portanto, de dar a ver a fragilidade do aparato frente à impermanência do tempo, e as imponderabilidades da memória no ato cinematográfico. Apostar nessa impossibilidade da memória pode ser um modo de empurrar filmes memorialistas (feito eminentemente de arquivos) para assunção do passado como uma ausência e um vazio, e a princípio entender que o filme só pode se fazer nessa lacuna, no esquecimento que é, ele mesmo, constituinte do tecido mnemônico e por isso propulsor da invenção. Como diz Gagnebin, a rememoração salva o passado não porque o conserva, "mas porque Ihe assinala um lugar preciso no chão do presente. (...) Somente esse trabalho de rememoração e de narração, sob a égide da morte e do túmulo, permitirá, como diz Benjamin em Rua de mão única, esculpir uma outra imagem, a do futuro" (2014, p. 248-249).

Assim é Já visto jamais visto (2014), ${ }^{8}$ último filme de Andrea Tonacci, que parece se instaurar no que chamamos de um devirmemória. Ainda que voltado para o passado no sentido de coletar, lidar e figurar as memórias de sua vida como filho, pai e cineasta,

8 Para uma perspectiva mais analítica desse filme, cf. VEIGA, 2015. 
Já visto não torna o memorial uma construção retilínea e unificada do passado. Tonacci entra em um devir-memória quando abandona qualquer preocupação narrativa prévia, e lida com arquivos, por ele mesmo, esquecidos (TONACCI, 2012) - mais de 40 anos de imagens filmadas (filmes acabados e inacabados, filmes de família e filmes de filmes) -, de forma afetiva permitindo que o fazer fílmico, na montagem especificamente, se torne um ato de distanciamento em relação a si e sua biografia, ato esse que propiciará que a memória instaure seu gesto. Aí, a memória se faz mesmo do esquecimento e o processo de amalgamar as imagens é guiado por esses buracos, portanto, lugar de invenção próprio do cinema. Como diria Benjamin, em reflexão sobre Proust, trata-se de um trabalho de rememoração espontânea "em que a recordação é trama e o esquecimento a urdidura" (1994, p. 37). O resultado é um filme ensaio, de relações frágeis entre os fatos que, conjugadas com a trilha sonora, gera uma ambiência nebulosa como a de um sonho, e o passado volta numa marchetaria de ritmos, de texturas, de imagens, de fragmentos de histórias fictícias e pessoais, reminiscências que a partir da história de vida do cineasta que se confunde com a do próprio cinema alcança uma história coletiva, do Brasil.

Sem o uso de um off organizador, mas também abrindo mão de testemunhos e entrevistas, o filme se pretende menos um relato sobre uma vida passada e vivida, do que um ensaio de modos de relação com a imagem, com o cinema, com o tempo, com o que é familiar nesse sentido tanto a lida com o pai, quanto com a ditadura no Brasil, é ao mesmo tempo próxima e distante. Abre-se então uma perspectiva histórica benjaminiana de saída, que opera com os vestígios de forma a não imobiliza-los, mas a fazê-los funcionar como lampejos de um tempo que resistem na sua possibilidade sempre aberta de inscrição. Contrário a um historicismo marcado pela memória como um dever, ${ }^{9}$

9 O dever de memória é esse que, segundo François Hartog (2013, p. 14-15), faz da história o registro, a preservação de um passado que precisa se manter intacto para não se perder frente ao presentismo contemporâneo, um presente onipresente que, em seu imediatismo, ao mesmo tempo em que nada conserva, nada quer esquecer. 
uma obrigação social de preservação, que impõe uma única ordem dos fatos, o cinema de devir-memória permite que a experiência pessoal - de cineasta pai e filho - deixe entrever a história como processo sempre inacabado que se reinstitui no próprio fazer fílmico - na lida com os arquivos, na montagem que aponta para possíveis e que não se esgota nunca. Assim o trabalho da memória é o trabalho do próprio cinema não como um resgate do que foi, mas como a invenção de um possível. Dessa forma, o já visto será sempre jamais visto.

\section{A processualidade}

Essa dimensão processual, fundamental para uma concepção não historicista, mas da história sempre em devir, é também a base para uma concepção do cinema enquanto obra - ato de obrar, de colocar em forma sem se esgotar na mesma - que aparece ainda em outras duas modalidades do cinema de escrita de si - o diário e o documentário de busca. Porém aqui a processualidade é fruto menos do trabalho da montagem como no cinema memorialista que lida com o manuseio de arquivos e mais no método implicado na gênese da imagem. Podemos dizer que no documentário de busca a processualidade está mais na dimensão imprevisível do ato de busca que move o filme, enquanto no filme-diário, embora o processo também guarde a imprevisibilidade, a processualidade é mais forte na natureza cotidiana e, portanto, precária e permanente da produção.

Foi Jean-Claude Bernardet que, em 2005, chamou o movimento da autobiografia fílmica no qual o realizador documenta seu processo de busca por um "objeto" pessoal, "documentário de busca". Na ocasião, Bernardet abordava os filmes Passaporte Húngaro (2003) no qual o projeto da cineasta Sandra Kogut é obter a nacionalidade e o passaporte húngaro -, e 33 (2002) - no qual o cineasta Kiko Goifman pretende encontrar a mãe biológica -, a partir não de uma análise fílmica mas do entendimento dos mecanismos e processos de trabalho dos diretores. A preocupação do autor tinha origem na compreensão de que os dois projetos partiam de um alvo preciso que poderia ou 
não ser atingindo, gerando então uma imprevisibilidade. Contudo, a pergunta do pesquisador era sobre como manter essa imprevisibilidade, que faz da filmagem uma documentação do processo, no momento da montagem, quando as incógnitas e suspenses já teriam se dissolvido. Ora, independente do que a montagem faria com o imprevisível que ocorreu no momento da filmagem - até porque ela (a montagem) pode se insinuar no processo mesmo de realização do filme ${ }^{10}-$, o que parece interessar é a concepção da busca como um ato em si, no qual o fim é menos um ponto de chegada do que de saída, é a partida para que a busca vire processo e se faça filme. Não se trataria, portanto, de um "fim que justifica os meios", porém dos meios eles mesmos, ou de um fim sem fim: uma vez é que o filme só existe enquanto processo de busca. Outra dimensão abordada por Bernardet é a tensão entre ficção e documentário que o gesto implica.

São filmes extremamente ricos justamente por isso, e que, nesse sentido, expressam uma subjetividade tal como muitos de nós a vivenciam atualmente. Não mais uma subjetividade como individualismo, mas uma subjetividade dinâmica, que não sabe em que medida é intima ou em que medida é produto da sociedade (BERNARDET, 2005, p. 151).

A dimensão ativa e processual da busca dificultaria 0 ensimesmamento do filme, o expandiria, ao abri-lo para situações, encontros e descobertas que a trajetória de sua realização, em seu caráter documental, encerra, promovendo então essa passagem de um interior, um eu narrativo, ficcionalizado, para o exterior, o outro. Há nesse movimento necessário de passar pelo outro, uma perda de autonomia, de algo da autoridade de quem fala de si mesmo. Portanto, esse eu, destituído em parte de seu poder, não concederia ao aparato cinematográfico a faculdade da revelação, de tudo ver e tudo mostrar. Ao contrário, com ele compartilharia a fragilidade, a impotência diante do mundo, tomando-o ao mesmo tempo em seus limites e potências:

10 Segundo Eduardo Escorel, "para cada material só existe um filme e que a questão toda é conseguir - e, às vezes não - decifrar qual é o filme que está contido naquele material. O trabalho da montagem é esse trabalho de decifração de uma coisa que, na verdade, já está contida ali, de diferentes formas, e em diferentes filmes" (MOURÃO E LABAKI, 2005, p. 154). 
o risco do fracasso de nada encontrar, mas também a abertura para o mundo, para o encontro, ou seja, a possibilidade de que algo aconteça. Isso só ocorre na medida em que a descentralização do eu, de uma memória individual, pela passagem pelo outro, é condição para que máquina cinema produza algo no mundo: uma experiência.

Ainda nessa passagem do eu ao outro, Bernardet lança luz para o modo como alguns filmes conseguem "inserir a história pessoal numa história muito mais ampla, numa história coletiva; ou abordar essa história coletiva através da história pessoal..." (2006, p. 153). Nesse ponto, retomamos o pensamento de Bernardet para tentar caracterizar o que seria essencial no cinema de busca: uma modalidade de cinema autobiográfico cuja história maior não aparece "como pano de fundo" para a história pessoal (2006, p. 156), mas uma história pessoal que, ao ser buscada, e de certa forma experienciada, evoca e revela uma memória coletiva, portanto histórica.

Já no diário o ensimesmamento parece, a princípio, inevitável, uma vez que ele se faz de notas pessoais, contudo tais notas podem advir da vida intima, mas também das interações que o diarista promove em seu ambiente, muitas vezes dos encontros na rua, no bairro, na cidade, que inserem o eu numa teia de relações perfazendo várias formas de sociabilidade. É possível dizer que o grande cineasta do filme-diário foi o lituano Jonas Mekas, que passou sua vida em Nova York e filmava seu dia-a-dia, a família, os amigos, as ruas da cidade. Entre sua extensa obra, destaca-se Walden: diary, notes e sketches (1969), uma colagem fluída e lírica de cenas do cotidiano vivido em Nova York - entre as quais o cineasta vira a câmera pra si mesmo - pontuada por dizeres poéticos e banais do próprio Mekas sob a forma de off e de cartelas. Em uma de suas frases, o cineasta define com propriedade o cinema diário: "vivo logo filmo". De natureza autobiográfica inconteste, por que uma escrita de si, o diário se afasta da autobiografia nessa medida em que frase dá a ver: trata-se menos de uma narrativa cronológica construída sobre a vida do cineasta, do que de notações diárias em forma de imagem colhidas aqui e ali nas 
situações ordinárias ou em eventos, de tudo aquilo que o cineasta participa. O diário obedece a um calendário, os dias são anotados, e essas anotações são os diários filmados que, como diz David James (2013), se transformam juntas no filme diário. Nesse sentido, o abrigo do "diário" em seu sentido corrente, o cotidiano se opõe aos grandes feitos e a uma ordem narrativa, é um nível no qual nos instalamos automaticamente, feito de repetições e insignificâncias contínuas, por isso inapreensível e escorregadio. Como diz Blanchot, o cotidiano é o que nunca vemos a primeira vista, mas sempre vemos de novo (1987, p. 14). O cotidiano é por si só precário e, por isso, o dispositivo diário ao se aproximar do mundo o encontra pelas lacunas e repetições, construindo um eu já de saída fissurado, incompleto, fracassado. Essa dimensão precária e em constante se fazer, confere ao filme diário sua natureza processual. Trata-se de uma obra sempre inacabada e sempre em constituição, o que permite que o cineasta/personagem também apareça nessa dimensão aberta, no ensejo dos encontros com outros e com situações quaisquer. Apesar do gesto de notações diárias parecer inscrever Walden num presente contínuo, na obra de Mekas há uma expressão nebulosa na forma de exposição, na montagem, na textura do filme, e no lirismo das cenas que evocam um passado ora bem próximo ora remoto. É como se a memória fosse menos os arquivos do passado, as notas em diário que o cineasta retoma e monta, e muito mais uma performance das próprias imagens que sugerem imagensauráticas, que apontam para algo perdido, similar aquilo que Deleuze definiu como objeto virtual "um elemento residual de um passado puro, preexistente ao presente que passa fazendo passar todo o presente" (CASTELLO BRANCO, 1990, p. 55).

Exatamente porque é parcial, porque ele se reduz a um resto um trapo, o objeto virtual jamais será algo resgatável, tangível, mas apenas algo que se vislumbra, que se sabe que existe exatamente porque falta, ou, nas palavras de Deleuze, "que existe como fragmento de si mesmo; só ê encontrado como perdido-só é perdido como reencontrado." Entretanto, em torno desse objeto parcial, fragmentado, incompleto, a memória se constrói, o presente se move e, simultaneamente, configura o tempo. Este termina por se constituir, portanto, 
no movimento de um presente descontínuo em torno desses objetos virtuais, desses trapos de passado que sempre escapam e que, no entanto, estão lá. (CASTELLO BRANCO, 1994 p. 56)

O exemplo brasileiro de um cineasta que transformou sua vida diária em filme é David Perlov. Nascido no Brasil, Perlov passou parte de sua vida em Tel Aviv. Em Diário (1973-1983), uma obra de 30 anos dividida em seis capítulos, que ao todo perfazem 330 minutos de filme, essa dimensão processual do filme diário enseja uma temporalidade outra que apesar de agarrada ao espaço cotidiano, portanto, como Mekas, também ligada a um presente contínuo se adensa ao longo de seis horas de uma obra construída a partir de um material de décadas de filmagem. Trata-se de uma temporalidade que incorpora a memória em oposição à fixidez e ao resgate do passado, mas que sobrevive como constituinte do vivido. A memória assim desligada do passado, por um método cinematográfico que cola vida e filme, ganha um estatuto produtivo, como impulso que move e, muitas vezes, moldura as cenas que virão, as próximas filmagem. O resultado é um cinema aberto aos encontros no presente, mas que reflete o passado e o coloca em perspectiva para o que virá. Ainda que próximo ao filme de família (assim como Mekas) esse produzido despretensiosamente em meio aos acontecimentos domésticos e as celebrações caseiras, a obra de Perlov é mobilizada por um olhar político do judeu que viveu a opressão e a esperança em Israel e que, portanto, questiona a todo o tempo as formas de injustiça que esbarra cotidianamente. Em meio à vida ordinária, bolsões históricos parecem se adensar dando a ver pelos enquadramentos rigorosos de Perlov, muitas vezes da janela de seu apartamento em Tel Aviv, ou do apartamento de amigos no Brasil, ou da própria tevê, conflitos e violências menores muitas vezes invisíveis à história oficial.

$\mathrm{Na}$ intenção de ligar essas várias figuras de escritura do cinema de experiência pessoal, tendo como eixo as formas de trabalho da memória, nossa pretensão foi menos de uma análise sistemática e 
cuidadosa dos filmes aqui evocados do que de inventaria-los de forma a dar a ver suas potências subjetivas e históricas. Buscou-se o quanto o pessoal em sua forma de lidar com a memória de modo a dar vazão a dimensão imaterial, fantasmática, onírica, inconsciente, pode nos ensinar para uma epistemologia da história que, em sua forma hegemônica, foi apartada do saber-ainda-não-consciente. Menos do que pensar essas figuras como uma classificação estanque de modalidades, mas entendendo que os filmes podem de alguma forma abarcar mais de uma delas, o objetivo final foi escapar de um sintoma histórico no qual o eu, o intimo, o pessoal, se ligam à imagem de forma direta e narcísica, apartada do passado, que, por sua vez, perde seu elo vital com o cotidiano e só pode ser acessado por uma operação intelectual e crítica como um dever coletivo de preservação a qualquer custo. O intuito dessa trajetória foi, através do cinema de experiência pessoal em sua dimensão tanto de práxis (a relação com as imagens) quanto formal (a relação entre imagens), descortinar uma política da rememoração na qual a dimensão viva, afetiva e inventiva da memória nos permita pensar não só a força histórica da inscrição subjetiva, mas força da inscrição subjetiva na história ela mesma.

\section{Referências Bibliográficas}

BENJAMIN, W. A imagem de Proust. In: Walter Benjamin - obras escolhidas: magia, técnica, arte e política. São Paulo: Brasiliense, 1994.

BERNARDET, Jean-Claude. Documentários de busca: 33 e Passaporte Húngaro. In: Mourão, M.D.; Labaki, A (orgs). O cinema do real. São Paulo: Cosac Naify, 2005.

BLANCHOT, M.; HANSON, S. Everyday Speech. In: Yale French Studies, n. 73, 1987.

CATELLI, Nora. En la era de la intimidad - seguido de: El espacio autobiográfico. Rosario: Beatriz Viterbo Editora, 2007.

CASTELLO BRANCO, Lucia. A traição de Penélope: uma leitura da escrita feminina na memória. Tese de doutorado. UFMG-FALE, maio de 1990.

COMOLLI, Jean-Louis. Voir et pouvoir. L'Innocence perdue : cinéma, télévision, fiction, documentaire, Paris, Éditions Verdier, 2004. 
DERRIDA, J. Gramatologia. São Paulo: Ed. Perspectiva, 1973.

DIDI-HUBERMAN, Georges. Diante do tempo: história da arte e anacronismo das imagens. Belo Horizonte, Editora UFMG, 2015.

DOUBROVSKY, Serge. O último eu. In: NORONHA, Jovita Maria G. (org). Ensaios sobre a autoficção. Belo Horizonte: Editora UFMG, 2014.

HARTOG, François. Regimes de Historicidade: presentismo e pxperiências do tempo. Belo Horizonte: Editora Autêntica, 2013.

JAMES, David E. "Diário em filme / Filme-diário: prática e produto em Walden, de Jonas Mekas". In: Jonas Mekas. P. Mourão (org.). SP: CCBB; USP, 2013.

NORA, Pierre. Entre memória e história: a problemática dos lugares. Projeto História. São Paulo, n. 10, dez. 1993.

NORONHA, Jovita Maria G. (org). Ensaios sobre a autoficção. Belo Horizonte: Editora UFMG, 2014.

MOURÃO, Maria Dora e LABAKI, Amir (org). O cinema do real. São Paulo: Cosac Naify, 2005.

RENOV, Michael. The subject of documentary. University of Minnesota, 2004.

SIBILIA, Paula. O show do eu: a intimidade como espetáculo. Rio de Janeiro: Nova Fronteira, 2008.

TONACCI, A. Dossiê Tonacci. Revista Devires: Cinema e Humanidades, FAFICH-UFMG, v.9, n.2, jul/dez. 2012. (p. 106-113).

VEIGA, Roberta. O maior e o menor no cinema pessoal: Diário de uma busca, Elena e Mataram meu irmão. E-Compós, Brasília, v.17, n.3, set./dez. 2014.

VEIGA, Roberta. Já visto jamais visto: um filme de filmes ou um devir memória. Crítica Cultural, Critic, Palhoça, SC, v. 10, n.1, p. 87-96, jan./jun. 2015. 


\section{AS DIFERENTES PERSPECTIVAS DA MEMÓRIA NA OBRA DE JOSÉ LUIS GUERÍN}

\section{THE DIFFERENT MEMORY PERSPECTIVES IN THE WORK OF JOSÉ LUIS GUERÍN}

Edição v.35 número 3 / 2016-17

Contracampo e-ISSN 2238-2577 Niterói (RJ), v. 35, n. 3

dez/2016-mar/2017

A Revista Contracampo é uma revista eletrônica do Programa de Pós-Graduação em Comunicação da Universidade Federal Fluminense e tem como objetivo contribuir para a reflexão crítica em torno do campo midiático, atuando como espaço de circulação da pesquisa e do pensamento acadêmico.

\section{CRISTIANE FREITAS GUTFREIND}

Professora do Programa de Pós-graduação em Comunicação da PUCRS. Pesquisadora do CNPq. Brasil.

cristianefreitas@pucrs.br

\section{RAFAEL VALLES}

Doutorando do Programa de Pós-graduação em Comunicação da PUCRS. Bolsista da CAPES. Brasil.

ra.valles@hotmail.com

\section{PPG $\mid C O M$ M}

AO CITAR ESTE ARTIGO, UTILIZE A SEGUINTE REFERÊNCIA:

GUTFREIND, Cristiane Freitas; VALLES, Rafael. As diferentes perspectivas da memória na obra de José Luis Guerín. Contracampo, Niterói, v.35, n. 03, dez. 2016/ mar. 2017. 


\section{Resumo}

Este artigo pretende fazer uma reflexão sobre a obra do realizador espanhol José Luis Guerín, procurando entender como a questão da memória se insere na construção narrativa dos seus filmes. Através de análise fílmica, este artigo parte do pressuposto de que a sua obra não é somente uma fonte importante para o entendimento da memória, mas também um meio que permite identificar a importância que a construção de imagens assume neste processo.

Palavras-chave

comunicação; cinema; memória

\section{Abstract}

This article aims to reflect on the work of spanish director José Luis Guerín, trying to understand how the issue of memory is included in the narrative construction of his films. Through a film analysis, this article assumes that his work is not only an important source for understanding the construction of memory, but also a means to identify the importance that the images take on this process.

\section{Keywords}

communication; cinema; memory 


\section{Introdução}

Para analisar a obra de José Luis Guerín é necessário assumir o desafio de pensar não somente as transitoriedades da representação cinematográfica, mas também a transitoriedade contida na construção da memória. Composta pelo incessante desejo de experimentar distintos suportes técnicos, abordagens narrativas, gêneros cinematográficos, a obra deste cineasta espanhol não se resigna a um método ou a uma classificação categórica. Ainda assim, diante desta diversidade de formas buscada pelo realizador, é possível afirmar que um tema percorre continuamente os seus filmes: materializar em imagens a questão da passagem do tempo e da memória.

Guerín é um entusiasta dos vestígios, dos rastros que testemunham um tempo que se foi ou que está em transformação. Assim iniciou a sua obra com Innisfree (1990) quando decidiu ir à Irlanda quase 40 anos depois das filmagens do filme The quiet man (1952) de John Ford, para ver onde e como se encontravam os habitantes que participaram deste filme. Os vestígios da memória também são o ponto de partida para se pensar Unas fotos en la ciudad de Sylvia (2007), onde o protagonista deste filme, feito a partir de fotografias, decide regressar 22 anos depois a cidade de Estrasburgo para tentar reencontrar uma mulher que havia conhecido. Guerín também flertou com um sentido arqueológico do cinema, ao criar uma história onde supostamente se "encontraram" materiais fílmicos do início do século $X X$ de um personagem intitulado Monsieur Fleury que registrava imagens caseiras da sua família (imagens estas que foram filmadas pelo próprio Guerín). Neste filme de ficção que transita entre um tom documental e poético, o diretor espanhol pensa a materialidade da imagem ao buscar nas ranhuras e deterioração do material em película, fazer uma reflexão sobre o envelhecimento e a corrosão das imagens através do tempo.

A obra de Guerín reflete sobre as limiaridades não somente narrativas entre documentário e ficção, mas também sobre a construção 
da memória, sobre como passado e presente se relacionam entre si. É neste espaço transitório composto por lembranças e esquecimentos, onde a fugacidade do momento presente se mescla com a referência das heranças culturais, que o cineasta espanhol desenvolveu com sensibilidade uma obra que busca compreender as fragilidades es processos limiares pelo qual se constrói a memória.

\section{Os limiares da memória}

Mas afinal, o que pode ser definido como limiar? De que forma é possível utilizar este termo a partir de uma obra cinematográfica como a de Guerín?

Um dos teóricos referentes para se pensar a construção do conceito de limiaridade foi o etnógrafo francês de origem alemã Arnold van Gennep, que procurou analisar este termo através do livro Les rites de passage, publicado em 1909. Com um viés de cunho mais antropológico, Gennep procurou refletir sobre os ritos de passagem que o homem enfrenta no seu processo individual e na sua relação com um meio coletivo. Para isso, dividiu basicamente estes ritos em três categorias: ritos de separação, como por exemplo, as cerimônias relacionadas a funerais; ritos de agregação, como é o caso do matrimônio e ritos de margem, como o processo de gravidez, por exemplo (GENNEP, 2008, p.25).

Dentro deste contexto dos ritos de passagem, Gennep assumiu especial atenção aos casos relacionados aos "ritos de margem", delimitando, assim, o conceito de limiar. Para o autor "passar o limiar, significa agregar-se a um mundo novo" (GENNEP, 2008, p.37). Como parte do processo de margem, Gennep partiu do entendimento de que os "ritos limiares não são ritos de aliança, propriamente dito, mas ritos de preparação para a aliança, precedidos por ritos de preparação à margem" (GENNEP, 2008, p.37-38).

Por último, Gennep dividiu os ritos limiares em três momentos, enquanto "ritos preliminares aos ritos de separação do mundo anterior, 
ritos liminares aos ritos executados durante o estágio de margem e ritos pós-liminares aos ritos de agregação ao mundo novo" (GENNEP, 2008, p.38). Gennep buscou, assim, construir um entendimento sobre o conceito de limiar enquanto pertencente a um rito de passagem, a um momento transitório tendo em vista um processo mais amplo de inserção em determinados grupos e contextos sociais.

No entanto, o que este presente artigo propõe analisar é um entendimento sobre um conceito de limiar que não fique restrito a uma visão de cunho antropológico e a relação que estabelece enquanto rito cerimonial. "O conceito de schwelle, limiar, soleira, umbral, seuil, pertence igualmente ao domínio de metáforas espaciais que designam operações intelectuais e espirituais" (GAGNEBIN, 2014, p.36). Existe um sentido mais subjetivo para se pensar a questão do limiar e que não esteja necessariamente atrelada a um sentido estritamente antropológico. Esse sentido possibilita apenas um ponto de partida para uma reflexão que transcende o entendimento dos ritos de passagem, como um "rito de preparação para uma aliança". O limiar é pensado aqui, também, como a construção de um campo de significações em que o seu sentido transitório e de fluxo o torne algo mais que somente um "caminho de preparação para um outro estágio".

Como afirma Walter Benjamin no seu Projeto Passagens (19271940), livro inacabado, onde o autor procurou realizar uma espécie de collage de citações para refletir, entre outros temas, sobre a significação do limiar, "é necessário distinguir com toda claridade o limiar do limite". O limiar (umbral) é uma zona. O termo "umbralar" implica mudança, transição, marés, e a etimologia não pode deixar passar estes significados (BENJAMIN, 2005, p.495).

Gagnebin realiza, também, uma reflexão que tenta dar sentido a ideia de limiar ponderando diferentes possibilidades:

(O limiar) lembra fluxos e contrafluxos, viagens e desejos. (...) O limiar não significa somente a separação, mas também aponta para um lugar e um tempo intermediários e, nesse sentido, indeterminados, que podem, portanto, ter uma extensão variável, mesmo indefinida. (...) O limiar designa, portanto, essa zona intermediária que a filosofia ocidental - 
bem como o assim chamado senso comum - custa a pensar, pois que é mais afeita às oposições demarcadas e claras (masculino/ feminino, público/privado, sagrado/ profano). (GAGNEBIN, 2014, p.36, 37)

Mas mesmo que Benjamin e Gagnebin procurem distanciar o entendimento do limiar em relação ao limite, classificar o limiar como uma zona inevitavelmente termina estabelecendo uma relação com a esfera dos limites, pelo simples fato de que uma zona em si também se constitui enquanto zona pelos seus limites. É partindo destes questionamentos que nos interessa entender aqui o limiar mais como um estado, um processo, uma dobra, um ponto de inflexão onde os seus movimentos promovem desestabilizações no pensamento, que busque no seus desvios desconstruir uma visão formada por dicotomias. Se a ideia de zona imprime limites ao termo, refletir sobre o limiar enquanto processo contribui para construir um campo de possibilidades para romper limites, atravessar fronteiras, para construir passagens tendo em vista um caminho de descobertas.

Se formos pensar, por exemplo, a questão da memória sobre a perspectiva da sua limiaridade, é possível entender o caráter transitório e frágil que assume um ato de rememoração na busca do indivíduo por lembrar fatos passados.

O limiar é, de maneira mais significativa, o que vacila entre o desaparecimento de algo e sua sobrevida como vestígio. (...) Porque o limiar conecta diversas modalidades de tempo, cujas estratificações se expressam em documentos, monumentos, arquivos, museus, arquitetura, cartazes publicitários. (...) 0 limiar e as passagens contém, ao mesmo tempo, o dentro e o fora, o antes e o depois. Por isso, "articular historicamente o passado não significa conhecê-lo 'como ele de fato foi'. Significa apoderar-se de uma reminiscência, tal qual ela cintila no momento de um perigo" (MATOS, 2015, p.107, 113).

Assumir as instabilidades de um ato de rememoração é começar a entender as limiaridades contidas dentro do âmbito da memória, enquanto um constante meio transitório onde se constroem a lembrança e o esquecimento, o presente e o passado, assim como o nível consciente e inconsciente na evocação de uma lembrança. "A reevocação não é 
algo passivo (...) Voltar a lembrar implica um esforço deliberado da mente; é uma espécie de escavação ou de busca voluntária entre os conteúdos da alma" (ROSSI, 2010, p.16).

$\mathrm{O}$ ato de rememorar encontra no seu exercício de evocação e na sua impossibilidade de tudo recordar, um caminho para construir a sua limiaridade. Podemos lembrar quais atividades realizamos ontem, mas nossas lembranças já se tornam imprecisas em relação ao que fizemos uma semana atrás. Buscar inspiração em Funes, o memorioso ${ }^{1}$ é nada mais do que constatar a impossibilidade de assumirmos total controle das nossas lembranças. Nessas imperfeições que constroem a memória, resgatar lembranças se torna uma atividade que está muito longe de ser objetiva e simples.

O processo de localização de uma lembrança no passado, por exemplo, não consiste de maneira alguma, como já se falou, em penetrar na massa de nossas lembranças como num saco, para retirar daí lembranças cada vez mais aproximadas, entre as quais irá aparecer a lembrança e localizar. (...) O trabalho de localização consiste, em realidade, num esforço crescente de expansão, através do qual a memória, sempre presente por inteira nela mesma, estende suas lembranças sobre uma superfície cada vez mais ampla e acaba por distinguir assim, num amontoado até então confuso, a lembrança que não encontrava seu lugar. (BERGSON, 2010, p.201) O ato de rememoração é transitório e caótico, transforma-se constantemente de acordo como a nossa subjetividade lidando com a passagem do tempo. Diante desta transitoriedade que opera entre o nível consciente e inconsciente do indivíduo, tornam-se necessário à presença de certos vestígios que auxiliem a evocar lembranças. Neste sentido, objetos, documentos, sensações, fragmentos que remetam ao que se busca lembrar são essenciais neste resgate de lembranças passadas.

Vestígios são signos duplos no sentido de que atrelam indissociavelmente a recordação ao esquecimento. É a clarividência quanto a esse esquecimento embutido

Conto do escritor argentino Jorge Luis Borges do livro Ficciones (1944), onde o protagonista possui uma memória prodigiosa que recorda todo tipo de fenômeno ou objeto. 
nos vestígios que rompe a linha contínua da tradição arrancando-a do passado, lançando-a por entre o presente, em direção ao futuro - e, é ela que torna estranho o passado. (ASSMANN, 2011, p.225)

Este fator é importante para entender Unas fotos en la ciudad de Sylvia, filme-diário que Guerín fez como um estudo prévio para realizar o filme En la ciudad de Sylvia. Ao regressar ao bar onde conheceu há 22 anos, Sylvia, o personagem-narrador José Luís, possui duas provas materiais que evocam estas lembranças: o endereço de uma livraria escrita num descansa-copos (Imagem 01) e uma caixa de fósforos do bar. Além desses objetos, somente permaneceram três lembranças: ela estudou alguns meses em Salamanca; ela gostava do som do seu nome em espanhol; ela começou a trabalhar como enfermeira. É através destes vestígios que Guerín estabelece não somente uma busca narrativa, mas também uma forma de encarar o seu ato de rememoração.

Guerín parte desta limiaridade entre lembranças e esquecimentos, entre vestígios e evocações para mostrar a transitoriedade por onde se constrói a memória. Sem estar restrita a conservação do passado, a memória se transforma diante da passagem do tempo. É partindo destas lacunas, que o personagem-narrador decide percorrer sem maiores precisões pelas ruas de Estrasburgo e pelos centros hospitalares da cidade em busca de Sylvia. Durante este processo não existe uma ilusão de encontrá-la, mas a constatação de que as inscrições do tempo neste ato de rememoração tornam esta tarefa ainda mais imprecisa e subjetiva. "Não guardo uma imagem nítida do seu rosto, talvez, ao reencontrá-la agora, não a reconheceria. No entanto, quando os ventos sopram desfavoráveis, regresso a esta cidade com o propósito secreto de encontrá-la" (03min.23seg.), afirma José Luís, o narrador. Diante da impossibilidade de lembrar algo mais, é o momento presente do personagem no seu processo de busca que se torna essencial no filme. 


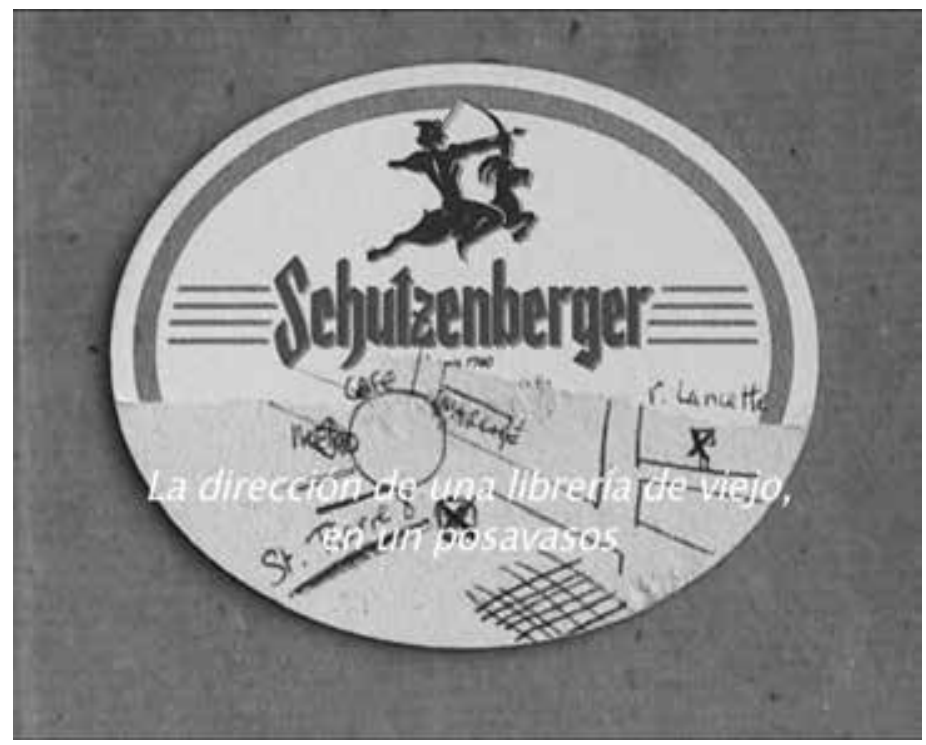

Imagem 01 - Fotograma de Unas fotos en la ciudad de Sylvia

Unas fotos en la ciudad de Sylvia compartilha da premissa construída pelo filósofo Henri Bergson de que "é do presente que parte o apelo ao qual a lembrança responde, e é dos elementos sensóriomotores da ação presente que a lembrança retira o calor que the confere vida" (BERGSON, 2010, p.179). É a ação presente que origina e determina o transcorrer do processo de rememoração, como um ato que está longe de ser passivo ou mecânico, uma vez que confronta diretamente as imperfeições da situação de recordar algo.

Nesse filme-diário, o objetivo vai além de conseguir ou não encontrar Sylvia e termina por despertar um processo de evocações da lembrança que originou o filme. "Em cada esquina a desaparecida é lembrada. Esta busca conduz meus passos. Busco um rosto em uma cidade, uma figura em um entorno" (34min.27seg.). Cada rosto que encontra nas ruas de Estrasburgo tem uma potencial Sylvia, cada retrato fotográfico captado tem uma evocação de Sylvia (Imagem 02). Diante de tamanhas imprecisões que impossibilitam uma busca mais direcionada, o que interessa em Unas fotos en la ciudad de Sylvia é o processo de busca de José Luís Guerín frente a sua própria memória a cada vez que se depara com novos rostos "na cidade de Sylvia". Nesta 


\section{Contracampo}

rememoração errante, vaga, imprecisa, Guerín estabelece passagens, fluxos, abre caminhos entre as suas lembranças precedentes e as lembranças que são geradas por essa busca, pelo registro fotográfico que revela o seu processo.

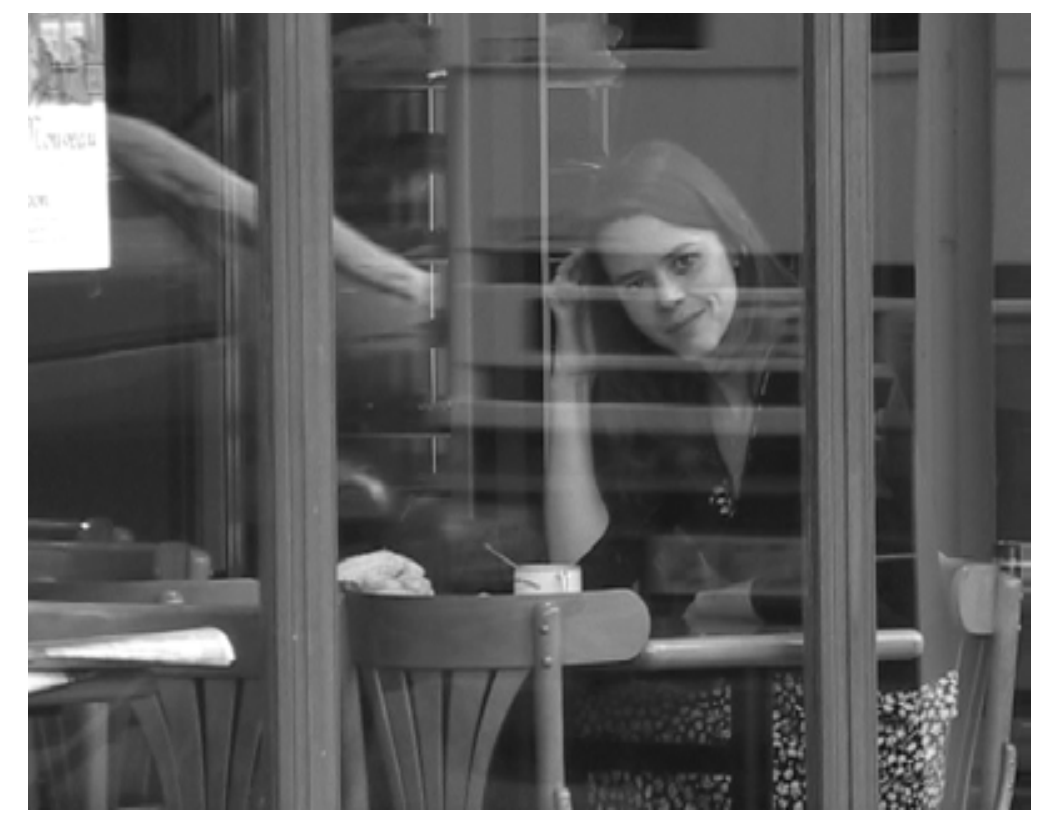

Imagem 02 - Fotograma de Unas fotos en la ciudad de Sylvia

Em Unas fotos en la ciudad de Sylvia "o regresso do passado não é sempre um momento liberador da lembrança, mas um advento, uma captura do presente" (SARLO, 2005, p.09). O fato de não alcançar o seu ponto de chegada, ou seja, de não encontrar Sylvia, fez deste caminho de buscas dentro do filme, um fim em si mesmo. Sylvia é a busca do narrador José Luís pelo seu próprio ato em rememorar algo, o desejo por entender como operam estes mecanismos de escavar as suas próprias lembranças, tendo em vista um passado que se encontra inalcançável e o quanto o momento presente interfere nesta construção.

\section{O filme como escavação de uma memória}

No limiar entre o esquecimento e a conservação, se constroem arquivos, escritas, registros audiovisuais que revelam a construção de suportes de memória. Ciente da fragilidade das recordações frente à 
passagem do tempo, o homem cria meios para manter, armazenar, não esquecer as suas vivências.

(...) a escrita não é só medium de eternização, ela é também um suporte da memória. A escrita é, ao mesmo tempo, medium e metáfora da memória. O procedimento da anotação e da inscrição é a mais antiga e, através da longa história das mídias, ainda hoje a mais atual metáfora da memória. (ASSMANN, 2011, p.199)

O próprio ato de escrever se torna assim um ato de rememorar, de fazer pulsar a memória, sem deixar que ela possa desvanecer no esquecimento. Neste exercício de subjetividade, a escrita se transforma, então, em um lugar de memória, na construção de arquivos que se tornam documentos que podemos recorrer diante de lembranças que fogem ao nosso domínio. "Cada dia anotado é um dia preservado. Dupla e vantajosa operação. Assim, vivemos duas vezes. Assim, protegemo-nos do esquecimento e do desespero de não ter nada a dizer" (BLANCHOT, 2005, p.273).

$\mathrm{Na}$ obra de Guerín, o registro audiovisual se afirma como a construção de uma memória, como testemunho de um processo tanto do realizador, como de um meio coletivo (povoados, grupo de pessoas), em um determinado local. É o que acontece, por exemplo, no documentário En construcción (2001), onde Guerín, em conjunto com seus alunos do curso de mestrado em Documentários de Criação da Universidad Pompeu Fabra, decidiu registrar durante o período de dois anos, a transformação do bairro El Raval, em Barcelona. Conhecido como "barrio chino", o que o filme documenta não é somente as histórias dos personagens que vivem neste local, mas também o processo de transformação urbanística que viveu este tradicional bairro barcelonês, que no final dos anos 90, começou a ceder espaço para a construção de novos edifícios.

Os registros de En construcción testemunham assim um processo de transformações e de embates entre o passado e o presente, entre uma memória coletiva e uma projeção de futuro. Não por acaso, Guerín inicia esse documentário com imagens de arquivo antigas do bairro, 
das suas ruas e de seus cafés. Essas imagens ganham um considerável contraste diante do trabalho das escavadeiras e demolições de prédios antigos nesse mesmo local durante os anos de 1998 a 2000, mostradas no filme. Nesse contexto, as próprias imagens de arquivo passam a serem vestígios de um período que naquele momento estava perdendo os seus referenciais com a modernização urbana que estava por vir. Ao partir da delimitação de um local, Guerín sai em busca dos vestígios de uma memória coletiva deste espaço. Como ele mesmo afirma, em depoimento para Víctor Paz Morandeira:

Um filme que me entusiasma é Nuit et brouillard (Alain Resnais, 1955), que está construído assim: como explicar o que passou nos campos a partir de um olhar sumamente objetivo, que busca signos, vestígios, nas distintas dependências do local, que o encara como um material muito objetivável e palpável. Esses signos são provas evidentes, como os vestígios das unhas que ficaram incrustadas no concreto das câmeras de gás. Para mim, essa tem sido sempre uma orientação: passear e observar. Me estimula outorgar um valor semântico aos vestígios que ficam em uma paisagem. (MORANDEIRA, 2011)

Mas En construcción consegue ir além quando estabelece uma ponte ainda mais ampla sobre os vestígios que começam a ser encontrados com o avanço destas obras. Em meio ao processo de construções e demolições são descobertas ossadas de humanos nos subterrâneos do bairro, identificados por arqueólogos como pertencentes ao Império Romano, do século $V$ d.C. (Imagem 03). Durante uma longa sequência de aproximadamente vinte minutos, Guerín se detém a mostrar tanto o trabalho dos arqueólogos em escavar e limpar os ossos, como também na reação das pessoas que passam pelo local, impressionadas diante de tal descoberta. 


\section{Contracampo}

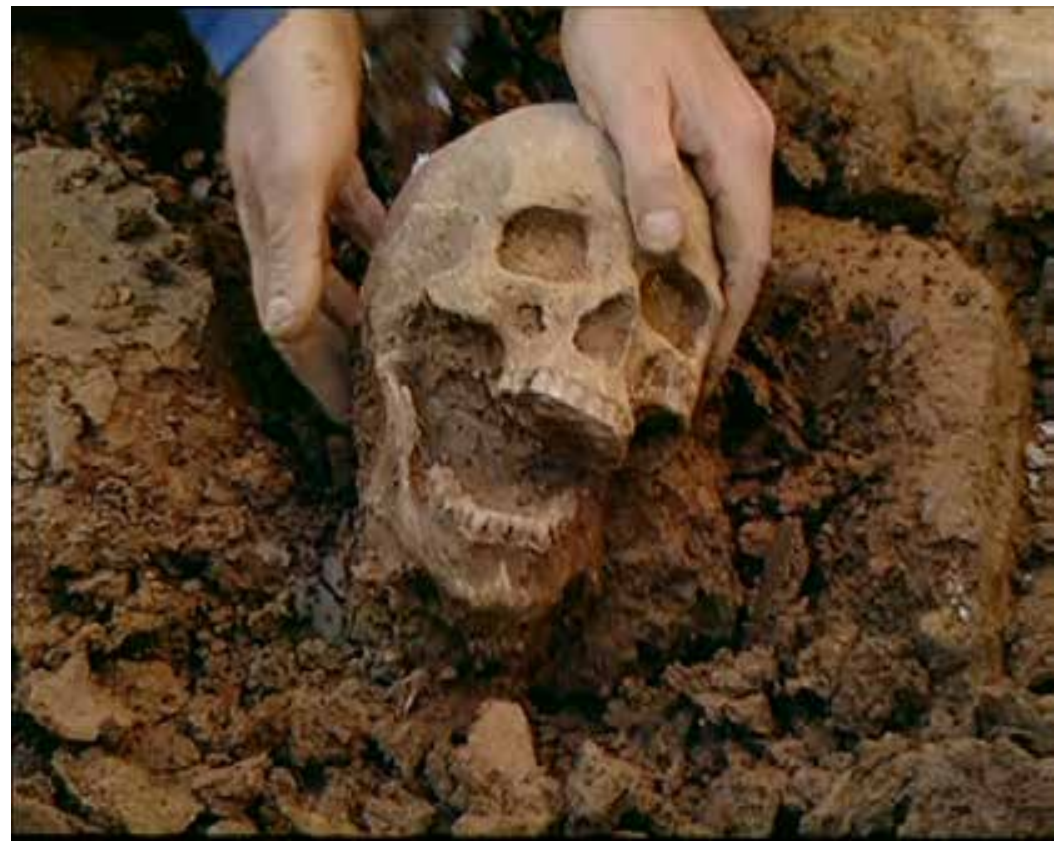

Imagem 03 - Fotograma de En construcción

O documentário possui o mérito de documentar não somente 0 fato em si (a descoberta das ossadas), mas também captar a limiaridade da situação: ao se construir um futuro, descobre-se o passado de forma involuntária. Diante dos olhares surpresos das pessoas sobre as ossadas, é revelada a existência de uma memória coletiva que estava soterrada por uma era moderna que pouco consegue remeter ao período romano ao qual pertencem estes corpos (Imagem 04).

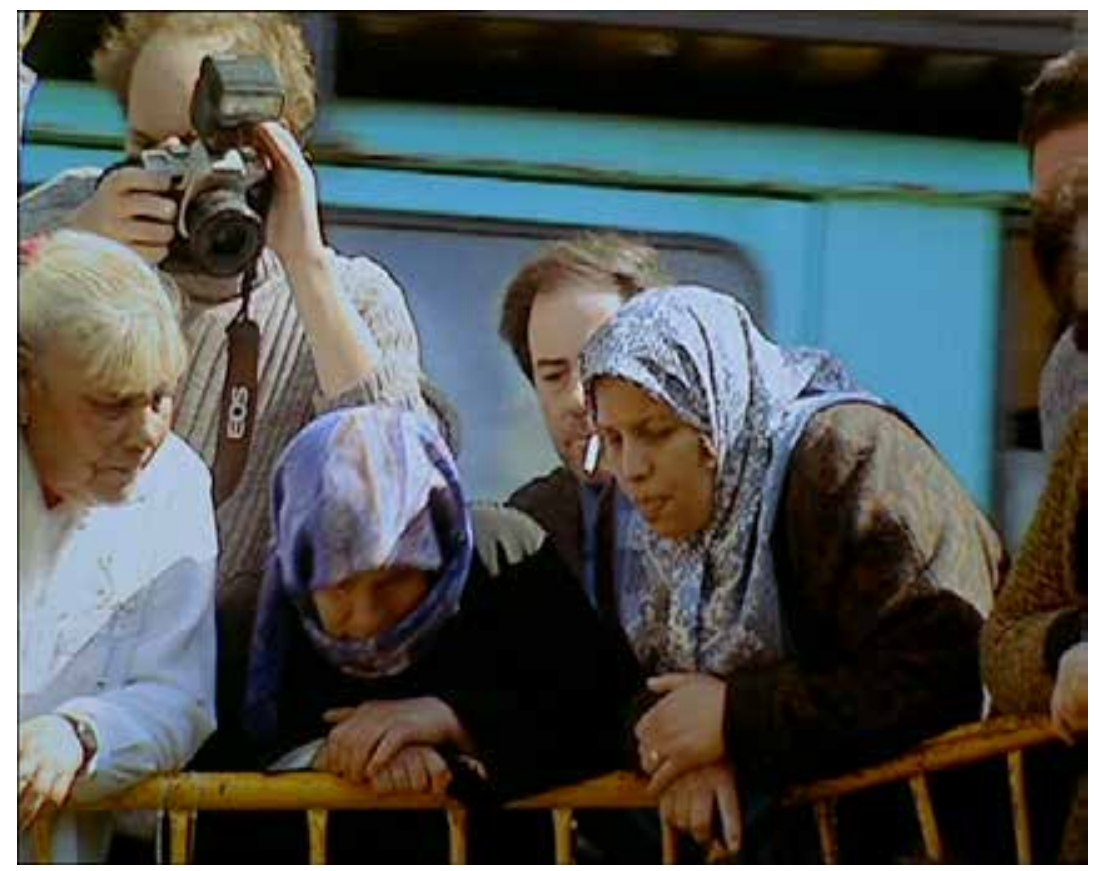


"Esta é uma coisa histórica e não se poderia ter tocado" (23min26seg), diz uma das pessoas que observa o trabalho dos arqueólogos; "incrível que vivemos em cima dos mortos e nem sequer nos inteiramos" (24min23seg), afirma outra senhora, "tomara que encontrem ouro" (25min26seg) diz uma criança. Jovens, crianças, senhores, famílias inteiras projetam suas visões pessoais ao observarem estes vestígios de uma época que desconheciam pertencer a este local. As imagens de En construcción revelam assim um choque temporal entre o presente (a descoberta dos ossos), em relação a uma situação passada (Século $V$ d.C.), tendo-se em vista o futuro (a construção de novos terrenos no "barrio chino").

Não por acaso, essa sequência do filme remete essencialmente a um estado limiar, a uma dobra, a um ponto de inflexão no próprio entendimento sobre a memória do local. Na medida em que este território foi literalmente escavado para além da sua própria superfície, isto também revela algo ainda mais simbólico para o entendimento sobre a relação entre limiaridade e memória. Se tanto Arnold van Gennep como Walter Benjamin buscaram entender a questão do limiar através do simbolismo que uma porta possui no processo de passagem, seja ela como "a porta dos muros do bairro, a porta da casa" (GENNEP, 2008, p.36) ou mesmo "a entrada do trem, da cervejaria, da pista de tênis, dos lugares turísticos" (BENJAMIN, 2005, p.23), o que a sequência de En construcción revela é que o limiar também é construído pelas escavações. Através de um processo, involuntário ou não, de escavar a memória, seja de um local, de um grupo de pessoas ou de um indivíduo, caminhos são abertos para entender determinado contexto a partir de uma nova perspectiva. É neste processo que se revela um estado limiar, um deslocamento de significações que promova um novo entendimento sobre determinada questão.

Norteado por essa ideia, Guerín iniciou sua obra em longa metragem também a partir de um processo de escavação da memória 
coletiva de um povoado no interior irlandês. É o caso do documentário Innisfree, realizado onze anos antes de En construcción. Interessado em saber como se encontram, quase quarenta anos depois, as pessoas e as locações do filme The quiet man (1952), de John Ford, Guerín decidiu ir para o interior da Irlanda para reconstruir este imaginário. A começar pelo contexto que envolve o filme que originou a proposta do documentário, Guerín se encontra novamente em distintas camadas memorialísticas.

A realização de The quiet man, para John Ford, foi a possibilidade não apenas de retornar à terra dos seus antepassados para filmar, como também a concretização de um projeto pensado desde 1937 em que o diretor pretendia resgatar a memória de muitos irlandeses que migraram para os Estados Unidos. The quiet man conta a história de um homem que decide regressar trinta anos depois a sua terra natal depois de partir para os Estados Unidos quando tinha 12 anos de idade. Ao regressar, decide comprar a casa onde viveu na sua infância e os terrenos que a rodeiam, mas para alcançar o seu objetivo terá que enfrentar um fazendeiro local e conquistar o respeito do povoado.

Se por um lado, John Ford fez este filme em busca das suas raízes, da memória dos seus antepassados, José Luís Guerín vai em busca do que a realização deste filme transformou na memória dos habitantes do local. Innisfree é um filme que busca o reencontro de um povoado com a sua própria rememoração, com as lembranças de um momento que transformou a história de seus habitantes. "A filmagem terminou três ou quatro meses antes que eu nasci. É uma lembrança, uma imagem que não somente herdei dos meus pais, mas também dos vizinhos e que transmitirei aos meus filhos" (01h.01min.57seg.), afirma uma das pessoas entrevistadas. "Minha melhor lembrança da filmagem foi ter conhecido essa gente maravilhosa, os bons momentos que passamos juntos e essas noites cantando e dançando. O que mais sinto agora é que eles já não estão vivos" (01h06min.03seg.), afirma outro habitante do povoado.

Décadas depois, permanecem as evocações deste passado. Uma 
das pessoas que participou das filmagens, ainda guarda como relíquia um isqueiro de John Ford (Imagem 05), onde está escrito "Capitan John Ford. Reserva de la Marina en el U.S.S Missouri" (01h.00min.23seg.). Outra pessoa lembra que em uma das festas da equipe, chegou a dançar com a atriz Mauren O'Hara. Em cada depoimento existe um estado de resgate da memória daquelas pessoas que presenciaram as filmagens, assim como um desejo de Guerín em potencializar essa busca.

Mas se já não bastasse encontrar este estado nostálgico, Guerín convoca também as crianças para descrever o argumento de The quiet man e comentarem as partes que acharam mais interessantes do filme. Desprovidas de lembranças, as crianças começam a construir as suas próprias lembranças ao participarem do documentário com seus depoimentos e descobrem as memórias existentes no povoado.

Ao visitar as locações do filme, como a estação de trem de Castletown, o riacho onde os personagens de Sean Thornton (John Wayne) e Mary Kate Danaher (Maureen O'Hara) atravessam felizes por estarem juntos, o bar local onde a equipe do filme se reunia para festejar (e que turistas americanos visitam por terem ainda a referência do filme, como afirma o dono do bar), faz de Innisfree um filme onde os lugares também evocam a reconstrução da memória. Guerín percorre as locações em busca de vestígios do que ainda permanece e do imaginário que se construiu do local através do filme. Mesclando as imagens atuais dos lugares com os sons do filme original, o realizador espanhol também constrói este estado limiar entre o passado e o presente, entre o imaginário do que se construiu e o que permanece no lugar. 


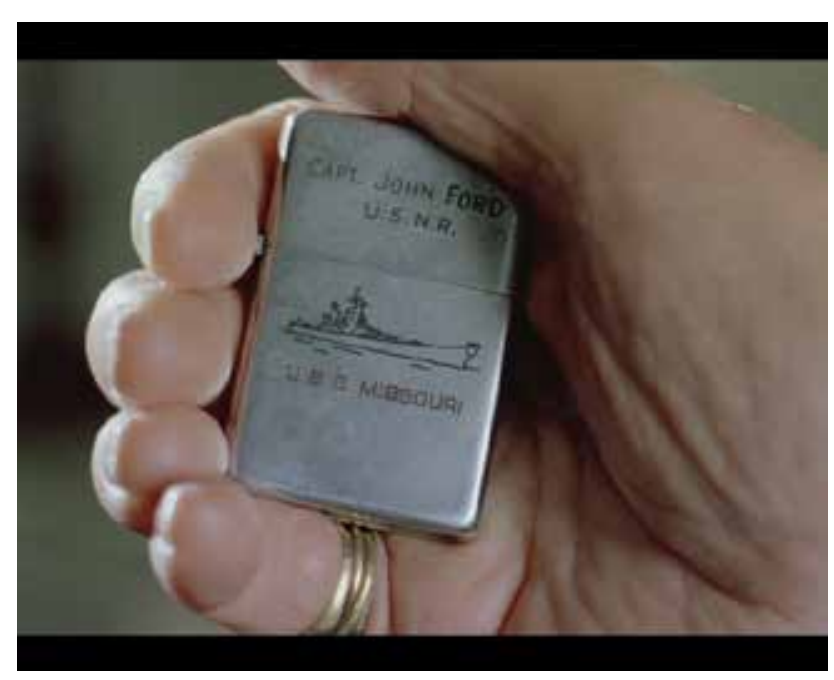

Imagem 05 - Fotograma de Innisfree

O que Guerín consegue evidenciar tanto em Innisfree como En construcción, é o caráter transitório da memória e como essa transitoriedade, através de um processo de escavação, revela limiaridades espaço-temporais. En construcción consegue captar momentos onde um passado até então desconhecido é revelado (como é o caso dos ossos encontrados no bairro El Raval) e termina alterando diretamente o momento presente daquele local (o fato das obras terem sido interrompidas ao descobrirem os restos mortais). Quanto a Innisfree, Guerín faz um filme sobre as lembranças de outro filme e termina revelando como um fato específico (a realização do filme de John Ford) acabou se tornando, desde então, determinante para a construção da própria memória e identidade do lugar.

\section{A imagem como conservação de uma memória}

Os filmes de Guerín revelam um tom fortemente autoral, repletos de deslocamentos estéticos e narrativos, construindo e resgatando memórias. No entanto, no que se refere ao realizador, poucos referenciais autobiográficos são evidenciados. Nesse sentido, assistir a sua obra não é propriamente um desejo em encontrar sua trajetória pessoal, como é possível perceber em autores de filmes-diário, como 
por exemplo, em Jonas Mekas ou David Perlov.

Porém, a partir de 2007, Guerín decidiu aceitar todos os convites de festivais para promover o seu até então último filme, En la ciudad de Sylvia (2007). Deste processo que levou dois anos atravessando territórios como a América do Sul, passando por EUA, Europa e Ásia, nasceu o filme-diário Guest (2010). Com sua câmera de vídeo portátil e sem equipe técnica, Guerín começou a registrar as cidades, as pessoas, os bastidores dos lugares por onde passou. Assumindo uma vez mais o formato de filme-diário que já esteve presente em Unas fotos en la ciudad de Sylvia, Guerín encontrou nos seus registros a construção de uma memória pessoal sobre estes dois anos de viagens.

As imagens de Guest se tornaram, assim, um testemunho do processo de interação de Guerín com outras culturas, de contato com pessoas que ele não conhecia previamente, de incontáveis deslocamentos de um país a outro. Ao mesmo tempo em que buscava conhecer e registrar o outro e desbravar culturas distantes da sua, Guerín também começou a materializar em imagens, a construção da sua memória pessoal sobre esse período. Se o formato diário, seja literário ou cinematográfico, se constitui como o lugar por excelência de retenção da memória contra o esquecimento, da escrita diária de pequenas vivências cotidianas como suporte de lembranças, Guest revela o desejo de Guerín por não deixar escapar as experiências vividas durante os dois anos de viagens.

Deste material registrado, Guerín também aproveitou para utilizar parte dele em outro projeto. Intitulado Correspondências (2011), e patrocinado pelo Centro de Cultura Contemporánea de Barcelona (CCBB), Centro Cultural Universitário Tlatelolco (CCUT-UNAM, México), La Casa Encendida de la Obra Social de la Caja Madrid e Acción Cultural Española $(A C / E)$, este projeto propôs a dez realizadores divididos em cinco duplas ${ }^{2}$, que realizassem ao longo de um ano, trabalhos de correspondência em formato de vídeo-cartas. A Guerín coube se 
corresponder com Jonas Mekas, fator este que resultou em nove vídeocartas, com aproximadamente dez minutos de duração cada. Nestes vídeos, um em especial chama a atenção quanto à questão da memória: a vídeo-carta número três, realizada por Guerín em maio de 2010.

Nessa vídeo-carta, Guerín apresenta uma moça eslovena chamada Nika Bohinc, que conheceu num festival de cinema de Lisboa, através de uma entrevista que ela realizaria com o diretor espanhol. Se era para ele ser o entrevistado, as imagens de Guerín revelam que ele acabou se tornando o entrevistador. Num determinado momento, ele pergunta se ela se lembra da primeira vez que foi ao cinema. Nika logo responde: "Sim, claro que me lembro. O primeiro filme que fui ver com meus pais foi Branca de neve. Não me lembro, mas me contaram que eu chorava tanto que tiveram que me tirar do cinema" (06min.56seg.) Nas imagens transparecem a sintonia entre ambos, além de revelar ternura, sinceridade, inquietações de uma jovem com menos de trinta anos e "com um destes olhares que nos ajudam a fazer filmes, a fazer cinema", como afirma Guerín no vídeo.

Mas ao final desta vídeo-carta, o choque. Guerín informa que Nika e o seu companheiro (Alexis Tioseco), assim que foram viver em Manila (Filipinas), foram assassinados no dia primeiro de setembro de 2009, em decorrência de um delito gerado por um grupo de delinquentes. As imagens de Guerín automaticamente levam o espectador a uma outra reflexão: o impacto da informação que fecha o vídeo, somado ao olhar final de Nika para Guerín (Imagem 06), revelam um sentimento de incomodo. Frente à morte, permanecem vivas as imagens. Frente à impossibilidade de Guerín em reencontrá-la novamente, permanecem os vestígios, a vivacidade de um encontro que já aconteceu e que não se repetirá mais. 


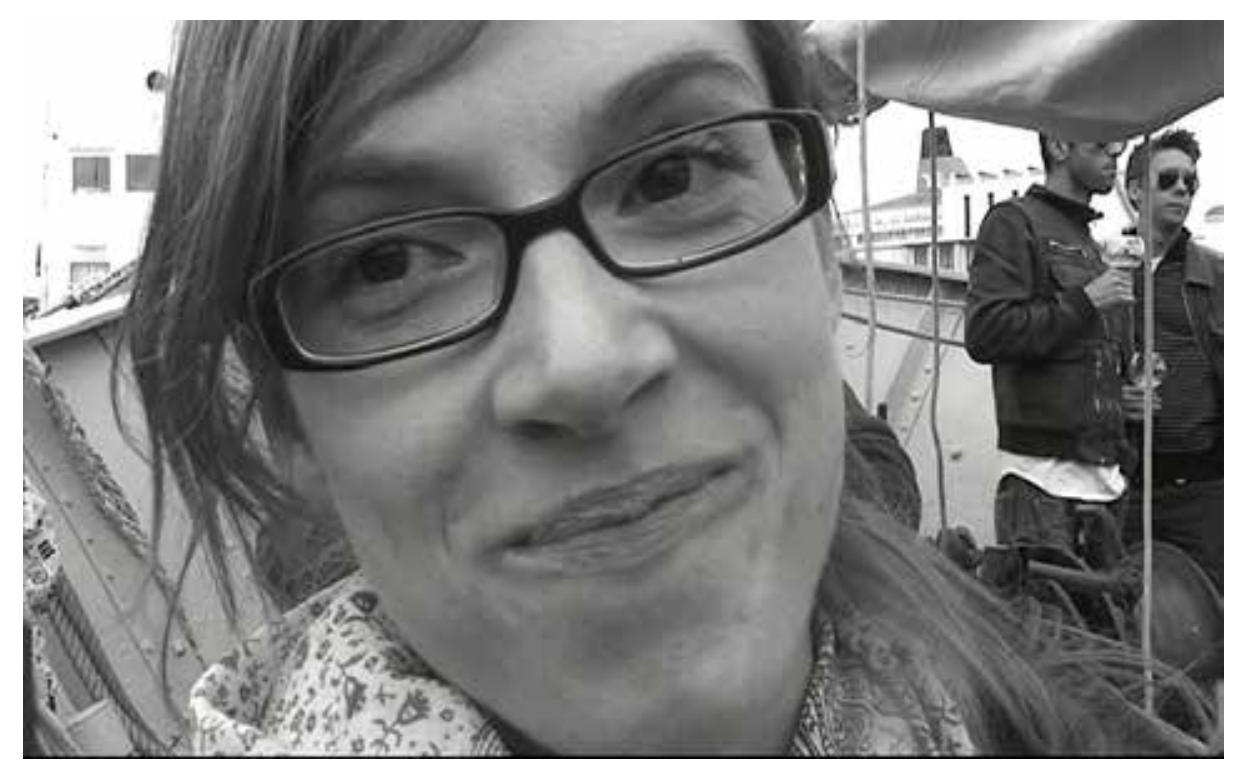

Imagem 06 - Fotograma de Correspondências

O olhar de Nika em direção a câmera se desdobra, vida e morte compartilham um mesmo estado limiar, uma mesma imagem. Frente à finitude da vida, essas imagens se tornam guardiães de uma memória. Ao rememorar esse encontro, Guerín nos confronta com a fugacidade da vida. Sua escolha por trazer a informação trágica ao final do vídeo acaba intimando uma reflexão sobre o sentido da imagem enquanto memória, pois se as imagens permanecem para nos lembrar da passagem do tempo, da fragilidade da nossa existência, também revelam "o embalsamento do tempo" (BAZIN, 1991, p.24), uma materialidade que procura reter a memória diante da ação inevitável do tempo.

\section{Considerações finais}

Realizar um ato de rememoração é desencadear um processo de deslocamentos. Neste caminho se constroem inflexões, escavações, se promovem estados limiares entre a lembrança e o esquecimento, entre a evocação de uma lembrança e os seus vestígios. Pensar o ato de rememoração desde a perspectiva da sua limiaridade contribui assim para se pensar o quanto a passagem do tempo interfere na 
própria construção da memória e no momento presente em que se busca rememorar.

É partindo destes apontamentos e análises feitos ao longo deste artigo, que a obra de José Luís Guerín ganha relevo. Seus filmes revelam a vitalidade contida no ato de rememorar, de encontrar nas nuances dessa situação, um caminho atravessado por fluxos e desvios. Seus personagens são construídos pela memória, se alimentam dela para existirem, como é o caso de Unas fotos en la ciudad de Sylvia. Ou então descobrem com espanto que uma memória coletiva estava logo debaixo dos seus pés, sem nunca antes terem conseguido perceber isto, como expõe En construcción. A memória também pode se tornar algo para ser repassado de geração em geração, como revela Innisfree, ou, então, se afirmar como um simples registro cotidiano na busca pelo outro, como ocorre em Guest.

Os filmes de Guerín revelam assim a um estado limiar contido no ato de rememoração, do seu lugar de evocação até a sua luta contra o esquecimento, passando por um caminho de descobrimentos e/ou reconhecimentos. De Innisfree a Guest, sua obra ganha transcendência para se pensar no estado transitório e frágil da memória, mas também para entender como as imagens são intermediarias e artífices deste processo.

\section{Referências}

ASSMANN, Aleida. Espaços da recordação: formas e transformações da memória cultural. Campinas, SP: Editora da Unicamp, 2011.

BAZIN, André. O cinema - ensaios. São Paulo: Brasiliense, 1991.

BENJAMIN, Walter. Libro de los pasajes. Madrid: Ediciones Akal, 2005.

BERGSON, Henri. Matéria e memória. São Paulo: Martins Fontes, 2010.

BLANCHOT, Maurice. O livro por vir. São Paulo: Martins Fontes, 2005.

GAGNEBIN, Jeanne Marie. Limiar, aura e rememoração. São Paulo: Editora 34, 2014.

GENNEP, Arnold van. Los ritos del paso. Madrid: Alianza Editorial S.A., 2008. 
MATOS, Olgária. "Pórticos e passagens: Walter Benjamin - Contratempo e história". In: MACHADO, Carlos Eduardo Jordão; MACHADO JR., Rubens; VEDDA, Miguel (orgs.). São Paulo: Editora Unesp, 2015. p.99-114.

MORANDEIRA, Víctor Paz. Entrevista a José Luís Guerín (Parte 1), 2011. Disponível em: http://www.acuartaparede.com/entrevista-jose-luis-guerin$1 /$ ?lang $=$ es

ROSSI, Paolo. O passado, a memória, o esquecimento: seis ensaios da história das ideias. São Paulo: Editora UNESP, 2010.

SARLO, Beatriz. Tiempo passado - Cultura de la memoria y giro subjetivo. Una discusión. Buenos Aires: Siglo Veintiuno Editores, 2005. 


\section{+WALKER EVANS +SHERIE LEVINE. CONSIDERAÇÕES SOBRE ARTE, FOTOGRAFIA E MEMÓRIA}

\section{+WALKER EVANS +SHERIE LEVINE. CONSIDERATIONS ON ART, PHOTOGRAPHY AND MEMORY}

Contracampo e-ISSN 2238-2577

Niterói (RJ), v. 35, n. 3

dez/2016-mar/2017

A Revista Contracampo é uma revista eletrônica do Programa de Pós-Graduação em Comunicação da Universidade Federal Fluminense e tem como objetivo contribuir para a reflexão crítica em torno do campo midiático, atuando como espaço de circulação da pesquisa e do pensamento acadêmico.

\section{GRÉCIA FALCÃO}

Doutoranda e bolsista FAPERJ no Programa de Pós-Graduação em Comunicação da UERJ. Possui mestrado em Tecnologias de Comunicação e Cultura pela mesma instituição, título concluído com apoio da CAPES, e graduação em Comunicação Social - Publicidade e Propaganda pela PUC-Rio. Com experiência profissional em fotografia e produção audiovisual para cinema e televisão, hoje é membro do Grupo de Pesquisa TRAMA - Comunicação, Arte e Redes Sócio-técnicas e do Laboratório de Pesquisa LETS - Comunicação, Cultura e Subjetividades, onde atua principalmente entre os temas: arte educação, arte contemporânea, fotografia, tecnologias da comunicação, sociabilidade online, experiência estética e produção de subjetividade. Brasil.

gre.falcao@gmail.com

\section{PPG ICOM conticatiou UFF}

AO CITAR ESTE ARTIGO, UTILIZE A SEGUINTE REFERÊNCIA:

Grécia. +Walker Evans +Sherie Levine: considerações sobre arte, fotografia e memória. Contracampo, Niterói, v. 35, n. 03, dez. 2016/ mar. 2017.

Enviado em 11 de setembro de 2015 / Aceito em: 11 de abril de 2016. 


\section{Resumo}

Seguindo o projeto benjaminiano, este artigo busca romper com a representação histórica que aprisiona os sentidos dos arquivos. Olharemos as obras de artistas contemporâneos que se apropriam de documentos fotográficos para discutir sua veracidade. Expressões artísticas que falam, justamente, da dupla vigência da fotografia - meio que cria aparências em busca de uma verdade histórica permanente e comum, ao passo que denota uma existência múltipla e efêmera, efeito das irregularidades que, no presente, legitimam o que é representado como fato verídico ou não. Com isso, esta análise trata da produção de sentido diante das imagens e da maneira pela qual o discurso histórico da fotografia passou a funcionar como "signo" de uma verdade.

\section{Palavras-chave}

arte contemporânea;

fotografia; experiência estética; tecnologias da comunicação

\section{Abstract}

Following Walter Benjamin's project, this paper seeks to break with the historical representation that imprisons the contemporary image meanings. We look precisely to artistic expressions that speak about the double life of photography - medium that creates appearances in search of a permanent and common historical truth, while denotes a ephemeral existence, effect of irregularities that, at the present, legitimize what is represented as truth or not truth. Thus, this article aims to analyse the production of meanings before the images and the way in which the historical discourse of photography began to function as "sign" of a truth.

Keywords
contemporary art; $\begin{array}{r}\text { photography; } \\ \text { aesthetic; }\end{array}$
communication




\section{Introdução}

Em Walter Benjamin, a imagem se apresenta como um conceito central para pensar arte, política e memória. Carregada de intensidades históricas, a imagem surge como alternativa para criar e redefinir as noções de temporalidade e ultrapassar a concepção científica que formalizou o tempo como unidade linear e cronológica. Numa crítica aos pressupostos da historiografia moderna, que lê o tempo por ordem sucessiva e linear, cadenciado do passado ao futuro, Benjamin trata de reconstruir esta história mediante a potência do que se mostra ao olhar. Imagens, saturadas de tensões, que podem romper com a aparência harmônica e preestabelecida do mundo e, "nos pormenores de seu conteúdo material" (BENJAMIN, 1994, p. 51), reordenar as forças do movimento histórico.

Em suas teses "Sobre o Conceito de História", pensar historicamente não é tornar única e singular a expressão do tempo, mas admitir outras possibilidades subjetivas aos acontecimentos. Fala-se, em suma, de uma autorreflexão sobre o papel do historiador diante da maneira como representamos os fatos históricos. E se há, no discurso historiográfico, uma distância crítica que interpreta o objeto tradicional pela divisão entre passado e presente, numa relação que se desloca e progride, o historiador benjaminiano deve ultrapassar tais fronteiras que distinguem épocas. Deve-se encarar o passado e o futuro como campos circunscritos no presente.

Trata-se do ideal de pesquisa do materialista histórico, termo cunhado por Benjamin para falar de um observador que confronta 0 teor factual dos objetos e o momento histórico ao qual este pertence. Seu papel é romper com as categorias de "real" e com um modelo de temporalidade cujo o princípio de compreensão se dá pelo progresso. Entende-se, portanto, que uma mesma época sustenta uma pluralidade de verdades, de desenvolvimentos heterogêneos, combinados entre si. Afinal, a história não é estável, de validade universal e constante. Ela diz respeito aos jogos que deram visibilidade a certo acontecimento. 
Ela retrata as forças de saber e poder que sustentam a forma pela qual certos relatos se tornaram legítimos enquanto outros se silenciaram, se tornaram invisíveis.

Não há, portanto, uma temporalidade espacialmente dividida que caminha linearmente, pelo contrário. Em Benjamin, a realidade histórica se reestrutura a todo instante, se atualiza no presente. Categorias de verdade, formas de vida, valores e visões de mundo que nascem por conflito, por confronto do passado com as oportunidades concedidas no contemporâneo. Nestes termos, o autor pensa a relação entre o passado e o presente enquanto despertar dialético, visto que só é possível enxergar o movimento temporal quando nos posicionamos em oposição às representações de cada época. Em outras palavras, a tarefa do crítico-historiador é articular passado e presente de forma a encarar a força dialética da história. Postura que nos convida a interromper o encadeamento linear dos fatos históricos, a estranhar os objetos de nosso próprio tempo.

Benjamin faz a crítica ao sujeito moderno, que decifra a realidade sob a pretensa imparcialidade científica e busca pressupostos metodológicos que pré-ordenam os acontecimentos. Atitude que, por consequência, criará um modelo de compreensão que define distâncias entre sujeito e objeto na análise historiográfica. Longe deste propósito, o olhar benjaminiano irá aproximar-se dos arquivos, dos relatos, das imagens, e deixar-se afetar por estas presenças. Sob tal condição, não é fortuita a influência do materialismo histórico de Marx nos escritos de Benjamin, visto que são as formas de expressão dos objetos, da estrutura técnica, que nos levam a resgatar a história em suas multiplicidades e diferenças políticas, estéticas, econômicas e socioculturais. Materialidades que carregam vestígios de outros tempos e, como sintomas, nos fazem romper com os modelos canônicos de temporalidade.

A história, contudo, não conserva, restaura ou representa um passado estagnado cronologicamente no tempo, mas dialoga, de forma anacrônica, com os limites impostos pelo corpo social do 
contemporâneo. Um tempo que se reestrutura a todo momento, seja sob a maneira pela qual o objeto se torna visível e compreensível no mundo, seja pelas instâncias que definem como, quando e onde o sujeito deve relatar certo acontecimento. Em linhas gerais, Benjamin trata das formas de produção, circulação e legitimação que constroem os lugares de verdade e de ficção, de real e irreal, por assim dizer. E resta ao historiador materialista ler, no presente, a construção destes territórios de reconhecimento e verdade.

Seguindo o projeto benjaminiano, este artigo busca romper com a representação histórica que aprisiona os sentidos dos arquivos. Olharemos para fotografias da arte contemporânea que assimilam o teor factual da história, mas mostram, em seu interior, uma série de contradições. Obras que falam justamente da dupla vigência da fotografia. Meio que cria aparências em busca da uniformidade dos códigos, de uma verdade histórica permanente e comum, ao passo que denota, per se, uma existência múltipla e efêmera, efeito das irregularidades que, no presente, legitimam o que é representado como fato verídico ou não.

Questiono a fotografia-documento em suas categorias de real, assim como Benjamin critica a veracidade do discurso historiográfico moderno. A fotografia é herdeira desta vontade científica de representar, catalogar, para oferecer uma explicação coerente e universal da realidade. Entretanto, reconhecer o mundo tal qual ele é, é ultrapassar estas forças que organizam e unificam a representação. Com isso, o problema da pesquisa não se restringe à definição dos fatos no tempo, mas pela maneira como este discurso histórico passa a funcionar como "signo" de uma verdade.

E para ver o que está por trás das imagens documentais, estaremos atentos a expressões artísticas que buscam evidenciar a dimensão lacunar do material de arquivo. Obras que fazem uso do documento para discutir sua veracidade. É o caso da série fotográfica "+Walker Evans +Sherie Levine" do artista americano Hermann Zschiegner. 


\section{A arte que se faz enquanto duplo}

A seguir vemos Allie Mae Burroughs, símbolo da Grande Depressão americana. Adentremos os pormenores desta imagem (figura 1).

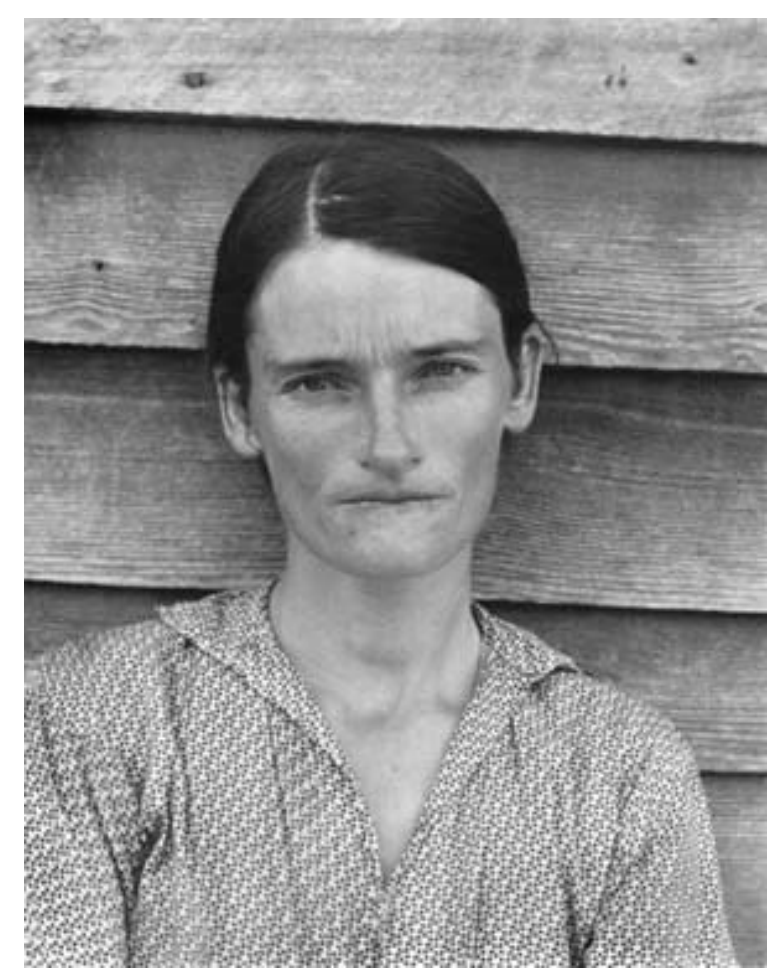

Figura 1 - Allie Mae Burroughs - Walker Evans, 1936.

O fotógrafo Walker Evans (1903 - 1975), um dos precursores da fotojornalismo, registrou, durante anos, os temas comuns da cultura americana. O movimento dos cafés de beira de estrada, o cotidiano das ruas nas pequenas cidades, a arquitetura dos comércios locais, dos cemitérios, das igrejas. Mas foi esta foto, tirada em 1936, que marcou sua obra.

No verão deste ano, Evans foi convidado pelo governo dos Estados Unidos para fotografar uma comunidade de assentamento construída para mineiros de carvão desempregados. O objetivo era compor uma reportagem que demonstrasse como o Estado se esforçava para combater a pobreza rural, uma das principais consequências da Grande Depressão. Evans, ao lado de fotógrafos como Dorothea Lange, foi incumbido de documentar a vida desses moradores. A 
família Burroughs, por exemplo, nada possuía. A casa, as ferramentas, os animais eram todos "emprestados". Eles pagavam os gastos com sementes, fertilizantes, medicamentos e ainda deveriam dar metade de sua safra de algodão e milho para o dono das terras. Walker Evans buscava provas da miséria local. Lá estavam elas. No entanto, suas composições fotográficas acabaram por transmitir algo a mais.

Dentre os vários personagens da comunidade, Evans fez quatro fotografias de Allie Mae Burrougs. Aquela que vimos é a mais emblemática (figura 1). Um olhar sério, neutro, quase indiferente. 0 retrato de um universo psicológico que caminha entre a dignidade e o descaso, da raiva ao conformismo. Esta foto se tornou ícone do período da Grande Depressão, enraizando-se profundamente na memória do povo americano. E desde as primeiras aparições em jornais, revistas e livros, as obras de Evans se tornaram influentes junto a nomes da fotojornalismo americano como Robert Frank. Surgia o desejo de estruturar os quadros fotográficos. De descrever diretamente os personagens, incorporando um mistério que retratava o lado trágico da vida. Uma sensação ambígua, contraditória, inexplicável, onde o espectador não chegava a encontrar uma mensagem na foto. Ele era apenas confrontado. Segundo Roland Barthes, ali estaria o emblemático punctum da fotografia. Algo que aciona um afeto. Uma instância tátil, pouco racional, onde "a luz, embora impalpável, é aqui um meio carnal, uma pele que partilho com aquele ou aquela que foi fotografado" (BARTHES, 1984, p. 121).

No entanto, com os anos, estas obras se tornaram modelos visuais e ditavam as premissas da boa fotografia. Davam conta de um "saber-fazer" que girava em torno da pulsão do instante fotográfico. Alvo de crítica nas obras contemporâneas, no final dos anos setenta, as estratégias de representação da arte passaram a ser questionadas por diversos artistas. É o caso da série "Depois de Walker Evans", de Sherrie Levine. Um de seus trabalhos mais conhecidos é a cópia do retrato de Allie Mae Burroughs. Levine simplesmente fotografou as páginas do catálogo de exposição de Walker Evans. E embora a reprodução do 
livro seja em formato reduzido, a artista imprimiu o registro no mesmo tamanho que o "original", e pôs a foto como de sua autoria (figura 2).

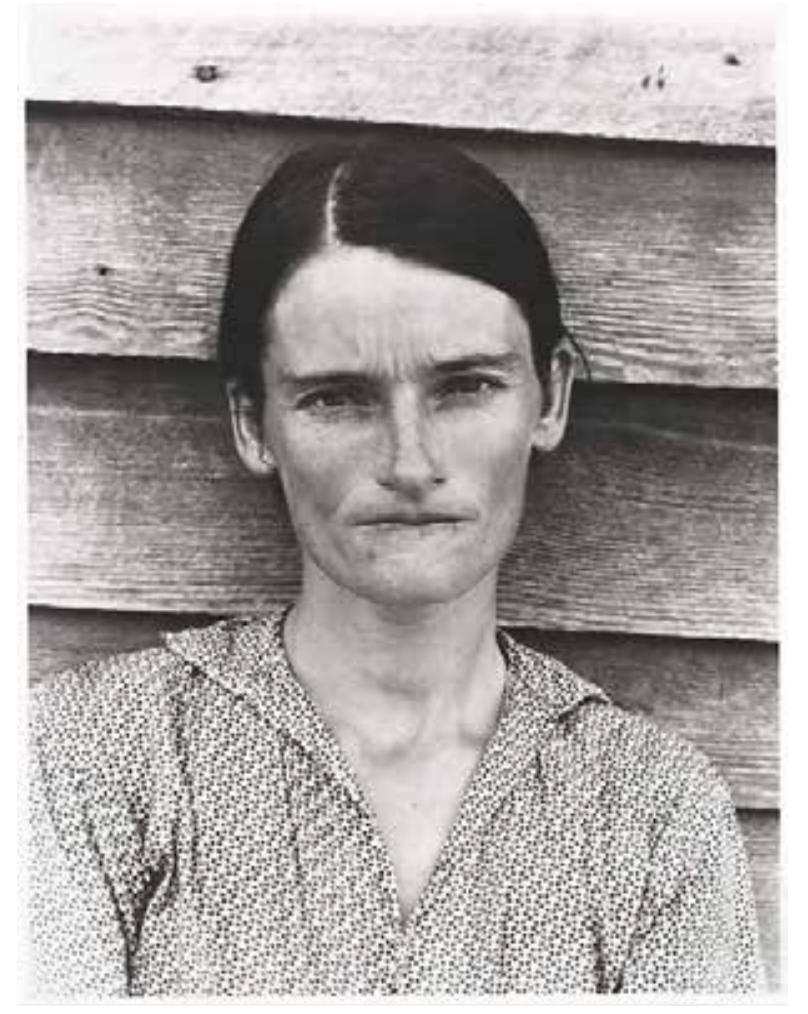

Figura 2 - "After Walker Evans" - Sherrie Levine, 1981.

Mas se fotografar é movimentar no espectador um jogo de fratura sensível, um singular embate entre aquilo que vemos e aquilo que nos olha (DIDI-HUBERMAN, 2010), de quem é esta imagem, senão de todos os elementos que, em última instância, montaram nossa forma de perceber a realidade? Em outras palavras, Evans pode ter sido o fotógrafo dessas obras singulares, mas não é o autor do fenômeno político, social, cultural e técnico que as levaram à evidência. As questões que envolvem os gestos de apropriação no contemporâneo delineiam, justamente, esta provocação nos territórios de legitimação do ver. Os fatores históricos que, desde o Renascimento, por exemplo, contribuíram para afirmação da figura do autor e da suposta singularidade das obras de arte.

Sherrie Levine não adiciona nem subtrai qualquer elemento ao registro de Walker Evans. A artista simplesmente copia sua obra tal 
qual Evans quis decalcar a "realidade" no Alabama. Aqui podemos fazer uma referência ao emblemático texto "A obra de arte na era de sua reprodutibilidade técnica", onde Benjamin disserta sobre a perda do "valor de culto" na arte diante do advento da fotografia. Para o autor, o que fascina o espectador de arte se conserva num conteúdo "aurático" dado pelo caráter singular da obra. Contudo, essa existência única e original da pintura, por exemplo, é substituída por uma existência em série diante das novas tecnologias de reprodução de imagens. As telas e até mesmo as esculturas, registradas pela fotografia, passam a aproximar o espectador dos encontros com a arte, mas acarretam no consumo massificado das obras, associado as novas dinâmicas do capital. Perde-se então o "valor de culto", a aura, que corresponde a experiência do olhar afastado, quase espiritual, onde a obra de arte se mostra como "aparição única de uma coisa distante, por mais perto que ela esteja" (BENJAMIN, 1994, p. 170).

Este aspecto ritualístico da arte, a aura, não deixa de ser um sentido enraizado na tradição, onde o valor da obra se define por seu composto de originalidade e singularidade. A fotografia vem abalar justamente as relações de propriedade e formas de produção e veiculação da arte representativa, rearticulando a distância espaço-temporal entre o sujeito e o objeto artístico. Contudo, até hoje respondemos às mesmas expectativas que, desde de o século XV pelo menos, valoram as artes como fazer único, criativo, dotado de autoridade.

A propriedade autoral da imagem não deixou de ser um fundamento das artes e ainda vigora firmemente no jornalismo e na ciência, se tratamos dos registros de cunho documental, por exemplo. Mesmo a obra de Sherrie Levine, que questiona a propriedade autoral na arte, não deixa de investir num certo gesto de autoria, contido não tanto na fatura do objeto, mas no pensamento crítico empreendido pela artista. Não é por acaso que sua ação de violar os direitos autorais de Evans se tornou uma marca "registrada" da arte contemporânea. Filhos do gesto dumchampiano do ready-made, por assim dizer. 0 famoso urinol (Fonte, 1917), invertido de cabeça para baixo, que saiu 
das fábricas e foi deslocado diretamente para as salas dos museus (DANTO, 2005).

Marcel Duchamp coloca um objeto banal, pré-fabricado, no espaço expositivo da arte. E quem haveria de dizer que aquilo não era arte? Quais são os limites que definem este território? Sua ironia irá desarticular os lugares de valoração dos objetos como um todo, e irá aproximar o fazer da arte dos usos empreendidos no cotidiano. Desde então, a apropriação artística é esse gesto que se nega a ler a obra estritamente pela forma. Extrapola-se, portanto, o entendimento das artes como manufatura, como o "saber-fazer" das vanguardas artísticas modernas que ainda buscavam ressaltar o caráter único e original do feito artístico, brincando no limite da forma e da figuração. Agora, na arte do contemporâneo, não é preciso presar pela artesania, pois o mesmo objeto de uso corriqueiro e valor ordinário é também nobre arte. A aura se rompe, mais uma vez.

Talvez por isso Phillipe Dubois (2011) trate a obra de Marcel Duchamp como fotográfica. Há ali outra ruptura nas formas representativas tal qual empreendida pelo surgimento da fotografia, que deu vigor ao movimento artístico modernista. Mesmo que o readymade não fale nos termos de uma transformação técnica no processo de criação e distribuição da arte, segundo o autor, as criações de Duchamp também estariam baseadas numa relação indiciária. Diante dos pressupostos da semiologia de Charles Peirce, alguns teóricos citam que a fotografia estaria fundamentada pela lógica do índice, visto que o referente, o "real", adere, necessariamente, ao registro técnico. Deixando de lado as discussões sobre as imagens simuladas por meio digital, tratamos deste lugar fotográfico que se preserva como prova da existência de algo. Nestes termos, a obra de Duchamp é também cópia, decalque da "realidade". Seu urinol, por exemplo, é tanto singular obra artística, valorada hoje em três milhões de euros, quando mictório do uso cotidiano. A peça traz, em si, um traço, um indício de "real" que mistura o escatológico e o repulsivo com o belo e o sublime do território artístico. Ela é um duplo e só se faz emblemática 
por estar, eminentemente, na fronteira entre o espaço de valoração da arte e da vida.

Tratamos, em suma, de um contemporâneo que extrapola o purismo visual. A arte se torna, antes de tudo, conceito. E, desde então, o que categoriza a autonomia da arte é a própria ironia de sua condição representativa. É o procedimento que nos permite negar e inverter as relações que construíram os valores perceptivos e separaram o artístico do ordinário; o autor do espectador; o humano e o técnico; o original e a cópia etc. Nestes casos, os artistas de hoje misturam suportes, gêneros e autores para exceder os limites dos usos na arte. Articulam, por exemplo, a fotografia junto à instalação, ao happening, à performance, à body-art, à land-art, ao site-specific. E usam a apropriação para fazer a obra existir por dubiedade. Uma maneira de questionar os objetos em seus significados preconcebidos.

Benjamin já procurou desenvolver uma nova perspectiva para a criação artística na modernidade, levando em conta o surgimento da câmera fotográfica. De maneira geral, a técnica irá registrar o mundo com mais eficácia do que os gênios da pintura em perspectiva, questionando as maneiras de fazer da arte renascentista, baseada na busca pela verossimilhança. Em outro ponto, o uso fotográfico irá "revalorar" a experiência sensível da arte, ampliando a circulação das obras fora de seu contexto original. Pinturas clássicas que foram fotografadas para circular no grande comércio, se tornando visíveis em diversos espaços para além do museu. Retomamos, aqui, a questão da perda da aura em Benjamin diante da reprodução técnica de imagens da arte. Algo que fala da ausência desse lugar de apreciação valorizado diante do único e do autêntico no contexto da tradição, da História da Arte. Hoje, como legitimar qualquer propriedade artística diante da desenfreada produção e circulação de imagens? Como salvaguardar a aura num contemporâneo que anula quaisquer efeitos de significado nas artes tradicionais como um todo?

Mais à frente veremos a interpretação de Georges Didi-Huberman sobre a aura benjaminiana, quando ele reintroduz a compreensão deste 


\section{Contracampo}

termo diante das atuais condições artísticas. Para este historiador da arte, a perda da aura pelo advento da fotografia não trata de um efeito apocalíptico nas artes, mas de um novo alento à experiência estética. Uma interrupção no modo contínuo da história que determinava o caráter único da obra, independentemente dos diferentes sentidos que ela adquirisse e pudesse transformar ao longo do tempo. Um novo regime (RANCIÈRE, 2010) que desfaz o nó da representação enquanto verdade de um passado estático e, sob um uso profanado (AGAMBEN, 2005) dos meios e materiais, modifica os significados do mundo. Falamos de arte enquanto anacronismo, enquanto estado de latência, enquanto objeto que perturba a história e as representações do tempo. Mas, por ora, citemos outra ironia da arte no contemporâneo.

\section{+Walker Evans +Sherrie Levine}

Exibida em 2011 no festival de fotografia "Les Rencontres d'Arles", a fotografia de Allie Mae Burroughs é novamente apropriada pela arte. Desta vez, o americano Hermann Zschiegner encontra a imagem pelo site Google e usa como parâmetro de pesquisa os dizeres "+Walker Evans +Sherrie Levine". Não por acaso, esse é o título da obra que consiste em vinte e seis fotografias de Allie, cada uma exibida junto ao endereço eletrônico da foto, ao tamanho do arquivo e a sua proporção em pixels (figura 3 e figura 4).

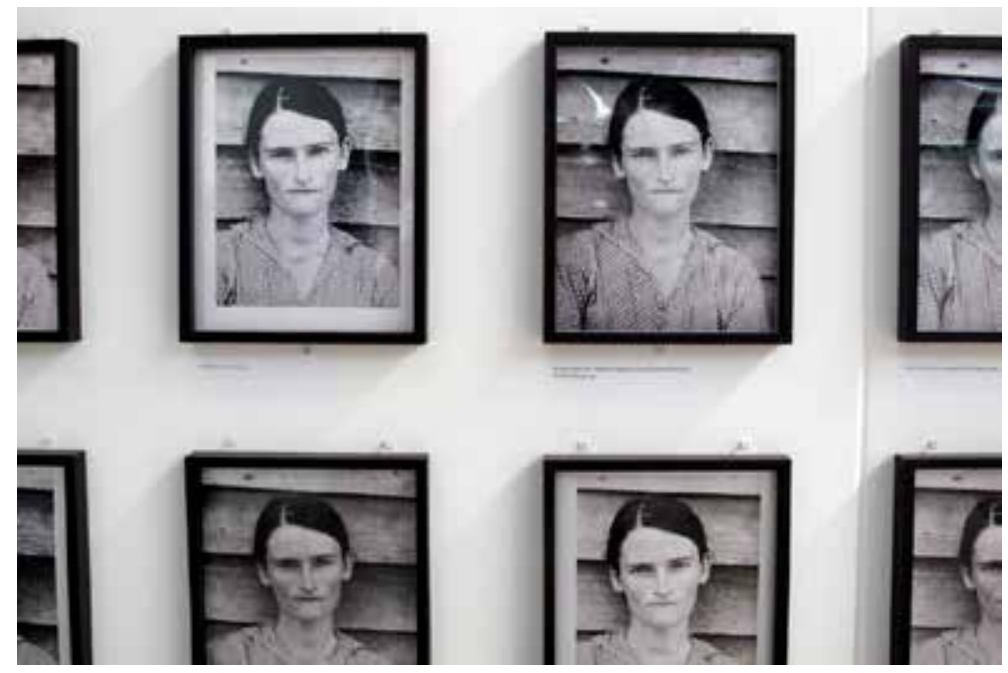




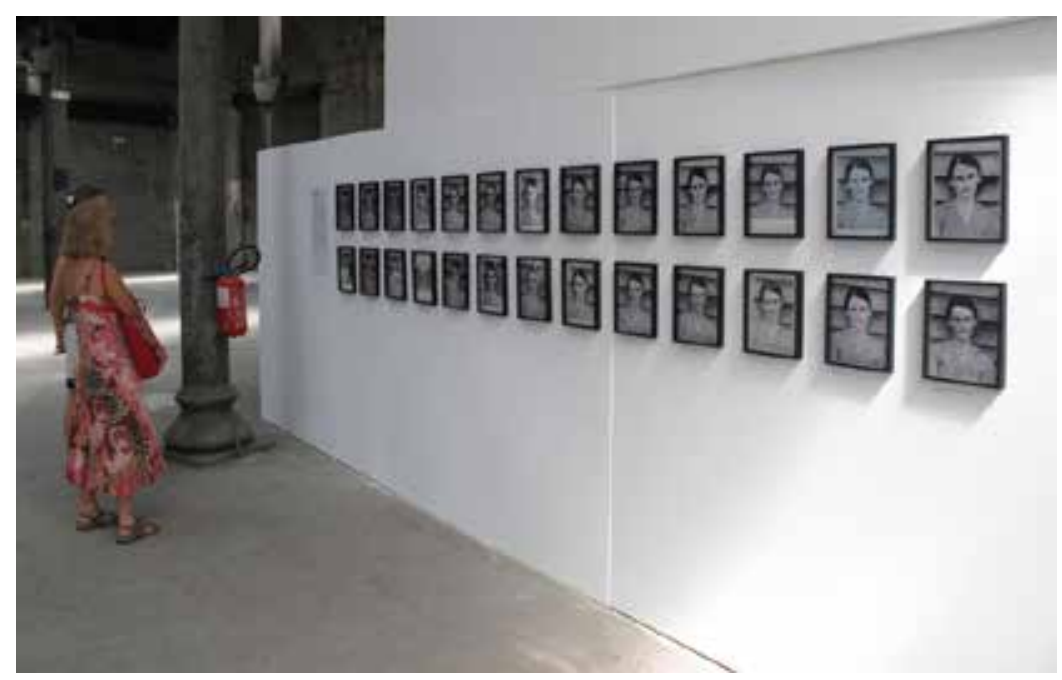

Figura 3 - Reencontres d'Arles, 2011.

Figura 4 - Reencontres d'Arles, 2011.

Como Sherie Levine, o artista também imprime os arquivos nas mesmas dimensões que a obra de Evans, mas ali encontramos divergências visuais. Enquanto algumas fotos são idênticas a "original", outras apresentam uma área em branco, um recorte na imagem, ou estão completamente distorcidas (figura 5). Tratam-se de diferentes versões do mesmo. Criadas, alteradas, manipuladas por diferentes usuários da rede.

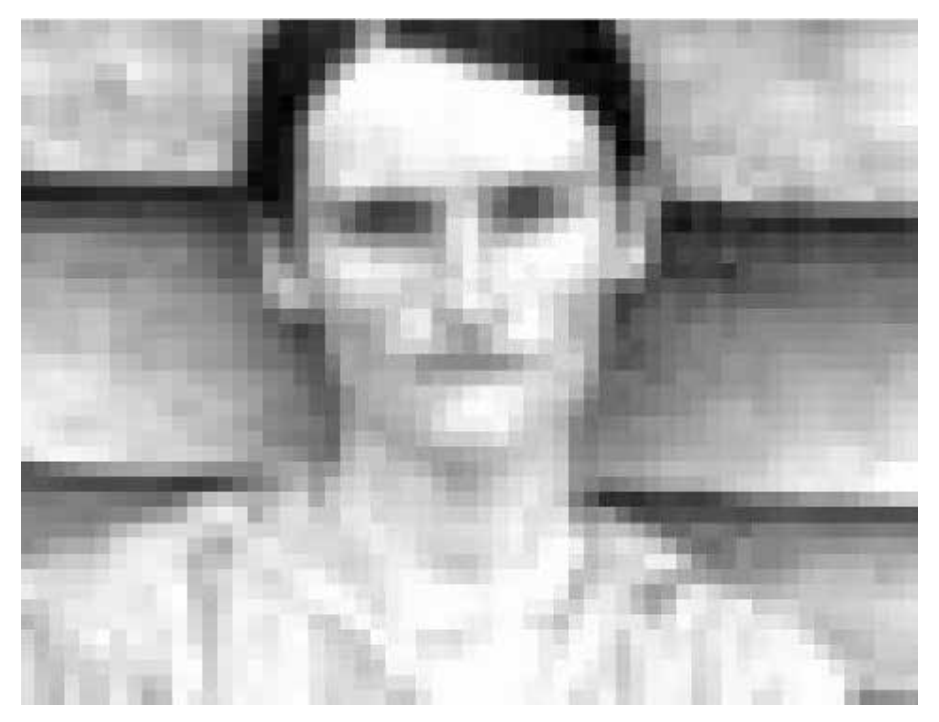

Figura 5 - Capa do catálogo de exposição: +Walker Evans +Sherie Levine Hermann Zschiegner, 2011. 
Surge aí uma nova crítica à relação autoral e ao caráter singular da fotografia, desta vez articulada à circulação das imagens na web. Hermann nos mostra a incoerência de se atribuir um único sentido a obra em questão, uma vez que os elementos que definem sua singularidade - o tamanho da foto, a forma visual, a autoria - se perdem e se modificam diante das mídias digitais. Nestes termos, buscar a foto de Walker Evans e de Sherrie Levine pelas ferramentas de pesquisa do Google é, por si só, ir de encontro a diversas identidades ocultas. Histórias invisíveis que atualizaram e deram notoriedade a este significado no contemporâneo.

Tal qual o historiador materialista, é nossa tarefa adentrar os pormenores das representações. Habitar os objetos da arte. Enxergar a lacuna de sentido contida em cada imagem que hoje circula e, assim, rescrever sua história. Embora inerente a todas as formas de representação, a dimensão lacunar do arquivo fica, de fato, muito evidente no contexto da web. Os links dispostos abaixo destas fotografias, por exemplo, são encontrados pela plataforma do Google por mecanismos de referência, tais como nome do autor, lugar e ano de produção. O link retém certa conexão com a obra de Evans e Levine em seu valor "original", mas também amplia esta identidade singular. Vincula a fotografia de Allie Mae Burroughs a uma trama de dados, em bits, sem que tenhamos a experiência com a totalidade deste percurso. Talvez por isso, Hermann, ao compor o endereço virtual como autor de cada cópia, nos leva a conceber o documento fotográfico por diversos caminhos possíveis. Caminhos que nos falam tanto de sua determinação histórica quanto de sua variabilidade constitutiva (figura 6). 


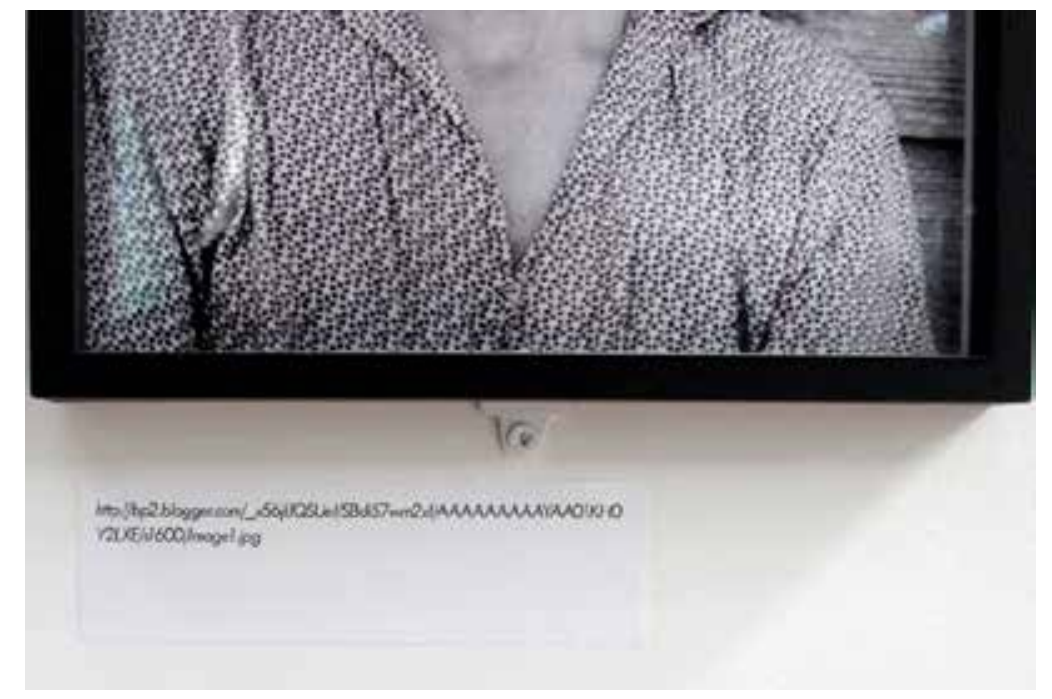

Figura 6 - Reencontres d'Arles, 2011.

Mas falar de um teor variável, de uma irregularidade no que se apresenta ao olhar, é necessariamente abdicar do caráter aurático da arte? Do contrário, no livro "O que vemos, o que nos olha", o filósofo e historiador da arte Georges Didi-Huberman faz uma releitura do conceito benjaminiano de aura. No lugar da arte que fascina pelos critérios estilísticos das Belas Artes, a aura seria uma relação de distância e tempo do sujeito com a obra. É, pois, uma relação espaço-temporal estabelecida entre o que vemos e a imagem que nos olha. Em suas palavras, "a aura seria, portanto, como um espaçamento tramado do olhante e do olhado, do olhante pelo olhado" (DIDI-HUBERMAN, 2010, p. 3). Essa definição nos afasta de encarar a aura pelos fundamentos da arte clássica, onde a obra encanta o espectador exclusivamente porque é feita com maestria, numa época longínqua e não é reproduzível a qualquer custo. Por um lado, não devo negar que a tradição clássica evoque uma concepção ritualística à arte, mas, para Benjamin, a função aurática "pode ser reconhecida, como ritual secularizado, mesmo nas formas mais profanas do culto do Belo" (BENJAMIN; DIDI-HUBERMAN, 2010, p. 4).

Por sua vez, para Didi-Huberman, o que é próprio da aura é o jogo perceptivo entre proximidade e distância, ou seja, aquilo que 
o espectador experimenta pelas proximidades sensoriais e distâncias significantes. É, portanto, uma instância intrinsecamente dialética. E tal qual o punctum de Barthes, que confere uma dimensão tátil à fotografia, a aura benjaminiana é uma distância que aflige, que nos intriga ao passo em que olhamos a imagem. Nesse ponto, as considerações de Benjamin sobre a arte entram nos mesmos moldes de uma crítica a historiografia tradicional. A aura é esse espaço corporal que nos faz reavivar os sentidos, mudar nossa percepção sobre o mundo e sobre as maneiras de se fazer história.

Para tanto, é fundamental que as obras de arte falem das condições perceptivas de seu tempo, usando dos meios e dos materiais para criar novas maneiras de compreender a história. São, por exemplo, os limites da técnica fotográfica que nos falam da construção inteligível do presente, e de outros momentos passados ou futuros. São as contradições nos seus usos comuns que criarão novas memórias, outros mundos possíveis a partir do que se apresenta ao olhar. Como investiga Didi-Huberman, a aura de Benjamin trata de um distanciamento, uma ausência capaz de criar memória. Um choque de sentido que inventa imagens novas, visíveis de repente. E é por isso que as imagens não só pertencem à história, mas perturbam o curso "normal" do tempo.

Não obstante, no livro "Máquina de esperar", Maurício Lissovsky trata da peculiaridade da fotografia clássica e moderna diante da maneira como ela ausentou o tempo. Como o clique fotográfico congelou o mundo e, simultaneamente, trouxe presença nessa ausência. Restanos, contudo, olharmos para as ausências do contemporâneo. Para os significados que se escondem pela profusão de imagens que circulam na atualidade.

\section{Referências Bibliográficas}

AGAMBEN, Giorgio. O que é o contemporâneo? e outros ensaios. Chapecó: Argos Editora, 2009.

BAUMAN, Zygmunt. Amor líquido. Sobre a fragilidade dos laços humanos.

BARTHES, Roland. A Câmara Clara. Nota sobre a fotografia. Rio de Janeiro: 
Nova Fronteira, 1984.

BENJAMIN, Walter. Obras escolhidas; vol.1. Magia, técnica, arte e política: ensaios sobre literatura e história da cultura. Brasiliense, São Paulo, 1994.

DANTO, Arthur C. A transfiguração do lugar-comum: uma filosofia da arte. São Paulo: Cosac \& Naify, 2005.

DERRIDA, J. Mal de Arquivo: uma impressão freudiana. Trad. Cláudia de Moraes Rego. Rio de janeiro: Relume Dumará, 2001.

2001.

La verdad em pintura. Buenos Aires, Barcelona, México: Paidós,

Pensar em não ver: escritos sobre as artes do visível (19742004). Trad. Marcelo Jacques de Moraes. Florianópolis: Editora da UFSC, 2012.

DIDI-HUBERMAN, Georges. "Ante el tiempo, ante el imagen". in: Ante el tiempo. Historia del arte o anacronismo de las imagenes. Buenos Aires: Adriana Hidalgo, 2006.

ATLAS. ¿Cómo llevar el mundo a cuestas? Tf Editores/Museo Reina Sofía, Madrid, 2010.

O que vemos, o que nos olha. Ed. 34, São Paulo, 2010.

Sobrevivência dos Vagalumes. UFMG, Belo Horizonte, 2011.

FLUSSER, Vilém. O Universo das Imagens Técnicas: elogio da superficialidade. São Paulo: Annablume, 2008.

A Filosofia da Caixa Preta: Ensaios Para Uma Futura Filosofia Da Fotografia. Rio de Janeiro: Relume Dumará, 2011.

FOUCAULT, Michel. Nietzsche, a Genealogia e a História. In: Microfísica do Poder. Ed. Graal, Rio de Janeiro. 1994.

HANS, Belting. O fim da história da arte: uma revisão dez anos depois. São Paulo: Cosac Naify, 2006.

LAGES, Suzana kampff. Walter Benjamin: Tradução e Malancolia. Ed. Universidade de São Paulo. São Paulo, 2007.

LISSOVSKY, Maurício. A Máquina de Esperar. Rio de Janeiro: Mauad $X$, 2008.

RANCIÈRE, Jacques. A partilha do Sensível: estética e política. São Paulo: EXO Experimental org.; Ed. 34, 2005.

Negro, 2011.

(2003), O Destino das Imagens, trad. L. Lima, Lisboa, Orfeu

(2008), O Espectador Emancipado, trad. J. M. Justo, Lisboa, 
Orfeu Negro, 2010.

VALADÃO, Claudia Mattos. Winckeman e o meio antiquário de seu tempo.

Revista Unicamp. São Paulo. 


\section{Temas}

Livres 


\section{O TRABALHO PUBLICITÁRIO: UMA JAM SESSION. IMPROVISO NA CRIAÇÃO E COTIDIANO COM POUCAS VARIAÇÕES}

\section{THE WORK OF ADVERTISING: A JAM SESSION. IMPROMPTU IN CREATION AND \\ EVERYDAY LIFE IN FEW VARIATIONS}

Edição v.35 número 3 / 2016-17

Contracampo e-ISSN 2238-2577 Niterói (RJ), v. 35, n. 3

dez/2016-mar/2017

A Revista Contracampo é uma revista eletrônica do Programa de Pós-Graduação em Comunicação da Universidade Federal Fluminense e tem como objetivo contribuir para a reflexão crítica em torno do campo midiático, atuando como espaço de circulação da pesquisa e do pensamento acadêmico.

\section{JOÃO ANZANELLO CARRASCOZA}

Mestre e doutor pela Escola de Comunicações e Artes da USP, onde atua como professor. Também é docente no Programa de Pós-Graduação em Comunicação e Práticas de Consumo da ESPM São Paulo, com pós-doutorado na Universidade Federal do Rio de Janeiro. Investiga as narrativas do consumo e a literatura. Ficcionista, recebeu os prêmios literários Jabuti, Guimarães Rosa, Fundação Biblioteca Nacional e APCA, entre outros. Brasil.

jcarrascoza@espm.br

\section{PPG|COM}

AO CITAR ESTE ARTIGO, UTILIZE A SEGUINTE REFERÊNCIA:

CARRASCOZA, João Anzanello. O trabalho publicitário: uma jam session. Improviso na criação e cotidiano com poucas variações.

Contracampo, Niterói, v. 35, n. 03, dez. 2016/ mar. 2017.

Enviado em 21 de setembro de 2015 / Aceito em: 5 de novembro de 2016.

DOI: http: //dx.doi.org/10.20505/contracampo.v35i3.875

1- Este artigo faz parte da pesquisa "Consumo e o ensino da publicidade por meio de obras literárias", patrocinada pelo CAEPM. 


\section{Resumo}

O trabalho publicitário vem passando por diversas transformações em virtude especialmente da presença de artefatos tecnológicos em seu dia a dia. A rotina dos profissionais de Criação, o seu processo criativo e certas peculiaridades laborais desta atividade, contudo, não se alteraram plenamente - preservam uma estrutura, senão inflexível, ainda rígida. Por meio de uma retextualização (Bettetini) - método que consiste em transpor textos de um domínio (o literário, por exemplo) para outro (o científico, neste caso) -, vamos investigar aspectos do trabalho publicitário por meio do conto $A$ soneca de Gretchen, de F. Scott Fitzgerald. Teorias sobre o processo de criação em geral e artística, crítica genética e elementos da gestão corporativa serão mobilizados em tal percurso.

Palavras-chave

Trabalho; Literatura; Criação Publicitária

\section{Abstract}

The work of advertising has been experiencing diverse transformations especially in virtue of the presence of technological artefacts in its daily life. However the Creation professionals' routine, their creative process and certain working peculiarities of this activity did not fully modify themselves - they preserve a structure, if not inflexible, but still rigid. By means of a recontextualisation (Bettetini) - a method which consists in transposing texts of one domain (the literary one, for example) to another one (the scientific one, in this case) -, we will investigate some aspects of the work of advertising by means of F. Scott Fitzgerald's tale "Gretchen's Forty Winks". Theories on the creation process in general and on the artistic creation, on genetic criticism and on elements of the corporate management will be mobilised in this route.

\section{Keywords}

Work; Literature; Advertising Creation 


\section{Improviso, jam session e criação publicitária}

O discurso publicitário, independentemente dos meios de comunicação nos quais se espraia, expressa valores das marcas anunciantes que, por meio das mais variadas estratégias de produção discursiva, visam sensibilizar o público para seus atributos corporativos e/ou para as qualidades de seus produtos e serviços.

Se, de um lado, nem sempre esse mesmo público consome materialmente aquilo que as marcas lançam no mercado, por outro, em virtude da extensão atual do sistema midiático, ampliado pela ubiquidade do universo digital, é impossível que não esteja consumindo largamente o discurso de tais marcas. Rocha (1990, p.27) afirma que "se compararmos o fenômeno do 'consumo' de anúncios e o de produtos, iremos perceber que o volume de 'consumo' implicado no primeiro é infinitamente superior ao do segundo".

Daí a importância de conhecer o modus operandi dos profissionais que criam os materiais publicitários (e a natureza de seu ofício), posto que são eles quem delimitam o "modo de ver" da publicidade - atividade, conforme Berger (1975), comparável a um "sistema filosófico", por promover uma visão particular do mundo.

Em seu já clássico livro Magia e capitalismo - Um estudo antropológico da publicidade, Rocha (1990, p.50) aponta que, para os próprios publicitários, "o conhecimento em publicidade se aproxima, por um lado, da noção de 'ciência' e, por outro, da noção de 'arte'". E Ramos (1985), um dos primeiros a escrever sobre a história da propaganda no Brasil, lembra-nos que a arte foi uma das matrizes da publicidade: como tal ofício surgiu no âmbito da mídia impressa, poetas e escritores foram os primeiros produtores de textos publicitários, bem como os pintores e artistas plásticos aqueles que cuidaram, inicialmente, da instância visual dos cartazes e anúncios feitos para promover bens de serviço.

Assim, o processo criativo publicitário incorpora, desde sua origem, procedimentos das artes em geral. E o trabalho artístico, 
seja qual for, sempre conta com o improviso, gesto que é capaz de surpreender, no ato da criação, as linhas de forças acenadas em sua prévia preparação. O improviso é, inesperadamente, o que emerge na própria ocasião do fazer, como numa jam session.

De acordo com Carrascoza (2008), o método criativo na publicidade se dá por meio de bricolagem, ou seja, a utilização de materiais que os criadores têm à mão, e o improviso é um dos elementos que entram nessa composição. Apesar do trabalho publicitário ser "guiado" pelas informações do briefing - conjunto de informações que pautam a criação -, o inesperado, o repentino, faz parte de seus passos. Ou, como enunciou o poeta Mallarmé (1991, p.149): "um lance de dados jamais abolirá o acaso".

Em Criatividade e processos de criação, Ostrower (1978) afirma que as matérias escolhidas pelo artista trazem possibilidades e impossibilidades, sendo, a um só tempo, limitadoras e orientadoras do curso criativo. Em outra obra, este autor discute longamente a ação do acaso no processo de criação artística (OSTROWER, 2001). E Cecília Almeida Salles, em Gesto inacabado, nos lembra que

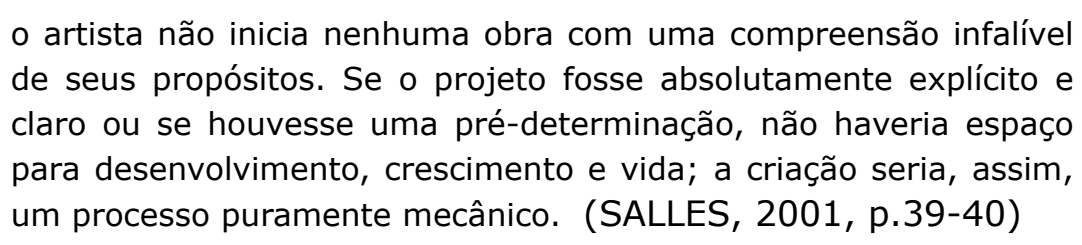

A qualquer momento, ao longo dessa expansão, em parte determinada pelas matérias que o criador põe em jogo, o acaso tem chances de se infiltrar.

O trabalho publicitário, podemos dizer, é regido, igualmente, pelos elementos que vão se definindo durante o processo de bricolagem, no qual o inesperado também é uma variante. Variante contínua, afeita à repetição, como a linha melódica do jazz. A rotina de uma equipe de criação publicitária pode ser comparada, por conta de certa improvisação, a uma jam session. E, assim sendo, buscamos na obra de F. Scott Fitzgerald, o "escritor da Era do Jazz", porta-voz dos fabulous twenties, uma história que nos permitiria abordar alguns aspectos da 
atividade laboral nas agências de publicidade - e, então, chegamos até A soneca de Gretchen.

Com esta história de Fitzgerald, vamos proceder a uma retextualização - método que, segundo Bettetini (1996), ao estudar as interações audiovisuais, permite transpor para um determinado campo de conhecimento (o científico) textos de um outro domínio (o artístico - precisamente, aqui, a literatura).

Noutras palavras, vamos "reler" o conto A soneca de Gretchen com o objetivo de discutir certos aspectos do cotidiano da área de Criação nas agências de propaganda - onde, de fato, o discurso publicitário é "modelado", e como seus profissionais atuam de forma semelhante ao dos artistas. Propomos, portanto, uma abordagem de cunho ensaístico, um extrato similar ao que Paixão (2014), estudando as margens indefinidas do poema em prosa, denomina de "arte da pequena reflexão".

\section{Porque o show publicitário não pode parar}

É noite, o outono havia terminado, as calçadas estavam cobertas de folhas e, certamente, haveria de nevar. Mas Roger Halsey, observando a paisagem lá fora, do alpendre de sua casa, entra logo na sala de estar e acende a luz do hall, pois "não dispunha de tempo para se preocupar com o clima" (FITZGERALD, 2009, p. 255).

Assim se inicia $A$ soneca de Gretchen, e a menção à falta de tempo nos encaminha, sem escalas, para o dia a dia das agências de publicidade, onde há atividades full time e o expediente dos "criativos" costuma ser uma longa jornada noite adentro. Isso porque Roger, logo em seguida, chama Gretchen, com quem está casado há três anos e tem um filho pequeno, para informá-la sobre um fato novo em seu trabalho. Há seis meses ele deixara a Companhia Litográfica de Nova York e começara, por conta própria, a trabalhar em publicidade. Como se não bastasse a mudança, que reduzira a renda da família, Roger anuncia, esperançosamente, para a mulher, que enfrentará um período 
maior e intensivo de trabalho:

...se você apenas acreditar em mim, o máximo possível, durante mais seis semanas, estaremos ricos. Consegui agora uma oportunidade de obter lucros do país. (...) Durante essas seis semanas não sairemos de casa, nem receberemos ninguém aqui. Vou trazer, todas as noites, trabalho aqui para casa. Correrei as cortinas e, se alguém tocar a campainha da porta, não atenderemos (FITZGERALD, 2009, p.258-259).

Três aspectos, estreitamente relacionados ao dia a dia publicitário, avultam dessa situação que abre o conto: 1) o ingresso de jovens nesse mercado profissional, atraídos pela ideia de ganhos rápidos e vultosos ("se você apenas acreditar em mim... durante mais seis semanas, estaremos ricos"); 2) o prolongamento de seu expediente ("vou trazer, todas as noites, trabalho aqui para casa") e 3) o impacto dessa nova rotina na esfera afetiva, daí porque Roger se põe a prevenir a mulher ("não sairemos de casa", "não receberemos ninguém aqui").

Vejamos cada um desses pontos, começando por essa mística, anunciada e reforçada pelos próprios publicitários - talvez como forma de atrair talentos das novas gerações para a sua arena -, de que os publicitários ganham altos salários, mesmo que sejam meros funcionários de agências, e os empresários desse setor, não importa qual for o seu porte, mais dia menos dias se locupletam, até se tornarem milionários.

Rocha (1990), em sua etnografia com um grupo de publicitários, nos mostra que essa não é senão uma "imagem" de si que eles mesmos constroem, discursivamente, para divulgar à sociedade. Contribuem para reforçar essa "crença", como apontado por Carrascoza (2011), os relatos autobiográficos de grandes nomes da publicidade nacional e internacional, como o clássico Confissões de um publicitário, de David Ogilvy, e Algumas coisas que aprendi em propaganda investindo 1 bilhão de dólares de grandes empresas, do brasileiro Julio Ribeiro, entre outros.

O eco dessa percepção distorcida continua a reverberar: criteriosa pesquisa feita com estudantes de publicidade e propaganda de diversas universidades brasileiras (CASAQUI, RIEGEL e BUDAG, 2011) aponta 
que os aspirantes à profissão identificam o publicitário com determinado estilo de vida que demarca suas diferenças em relação a outros, ou, em outras palavras, um estilo de vida que Ihe dá distinção. Ainda na visão desses estudantes, o ofício publicitário está associado ao sucesso profissional e aos prêmios concedidos pelos agentes do mercado. Mas, para ingressar na profissão, e galgar a glória, eles estão predispostos a enfrentar longas horas de trabalho - com retornos financeiros baixos, pelo menos inicialmente.

Esse é outro traço representativo da atividade do publicitário - o início penoso como pré-condição para que ele alcance, invariavelmente, no futuro, os altos-salários "garantidos" pelo campo. O subtítulo de Cartas a um jovem publicitário, obra de um importante advertising man brasileiro, Roberto Duailibi, sintetiza a presença desse binômio: "Nem tudo é festa. Como vencer na vida fazendo muita força!" É preciso muita força para atuar em publicidade, pois nem tudo é festa, mas, por outro lado, não há como não vencer - é uma carreira já, por si só, de sucesso.

A pesquisa de Paulino (2011, p. 85-86), sobre o perfil socioeconômico dos profissionais de uma grande agência de publicidade nacional, demonstra, pelo nível e faixas de salário apurados, que os altos valores são mais uma "lenda" do que uma realidade cotidiana. E que nem sempre os ganhos maiores estão associados a um tempo maior de trabalho na empresa.

O segundo aspecto em questão, que o conto de Fitzgerald nos permite focar, é não apenas a longa, mas também elástica, jornada de trabalho dos publicitários. Não é incomum que esses, como Roger Halsey, levem trabalho para terminar em casa, ou, o que é mais opressivo, se mantenham na empresa até altas horas da noite, quando não atravessam madrugadas elaborando e/ou finalizando campanhas.

Esse antigo "costume", de "obrigar" o funcionário - com a conivência dele -, a permanecer na agência até que os jobs tenham sido plenamente realizados, agravou-se nos últimos tempos com a aceleração do ritmo laboral pelos novos artefatos tecnológicos: 
As tecnologias suprimiram os intervalos, o deadline aumentou ao ocupar os intervalos que propiciavam ao profissional respirar, distanciar-se; estabelecer rotinas mais compassadas. Esse ganho de tempo já foi consumido e perdido pelo acréscimo e volume gigantesco de trabalho que se assumiu a partir de então (PAULINO, 2011, p. 105).

Duailibi (2006, p.100) afirma que "nada faz as agências perderem tantos seus clientes quanto o não-cumprimento de prazos". $E$, obviamente, a pressão recai sobre os funcionários que, se no passado gozavam de alguma pausa para catalisar seu processo criativo, agora enfrentam a naturalização não apenas das horas extras, mas também do tempo reduzido para maturar as suas ideias. Como, então, proceder à "materialização do sensível" diante dessa progressiva escassez temporal? Salles argumenta que

limites internos ou externos à obra oferecem resistência à liberdade do artista. No entanto, essas limitações revelam-se, muitas vezes, como propulsoras da criação. $O$ artista é incitado a vencer os limites estabelecidos por ele mesmo ou por fatores externos, como data de entrega, orçamento ou delimitação de espaço (SALLES, 2001, p.64).

A utilização crescente de ready-mades em peças publicitárias - de textos ou imagens já prontos, deslocados para a moldura da publicidade -, como investigado por Carrascoza (2008), pode ser uma das consequências do estreitamento do "ócio criativo". É outra solução advinda do improviso e, com essa nova "lei", a jam session também muda de ritmo - afinal, o show da publicidade não pode parar.

Assim, com menos tempo para encontrar soluções, os profissionais de Criação apelam para o emprego de enunciados verbais e/ou visuais já conhecidos, que exigem uma adaptação, ainda que criativa, mas não toda uma criação a partir de elementos difusos, como costuma ser o início, o disparo protoplasmástico, do processo. O anúncio da Apple (fig. 1), elaborado com ready-made, exemplifica com precisão esse estratagema, que se tornou um método criativo intensamente utilizado pelos publicitários. 


\section{Contracampo}

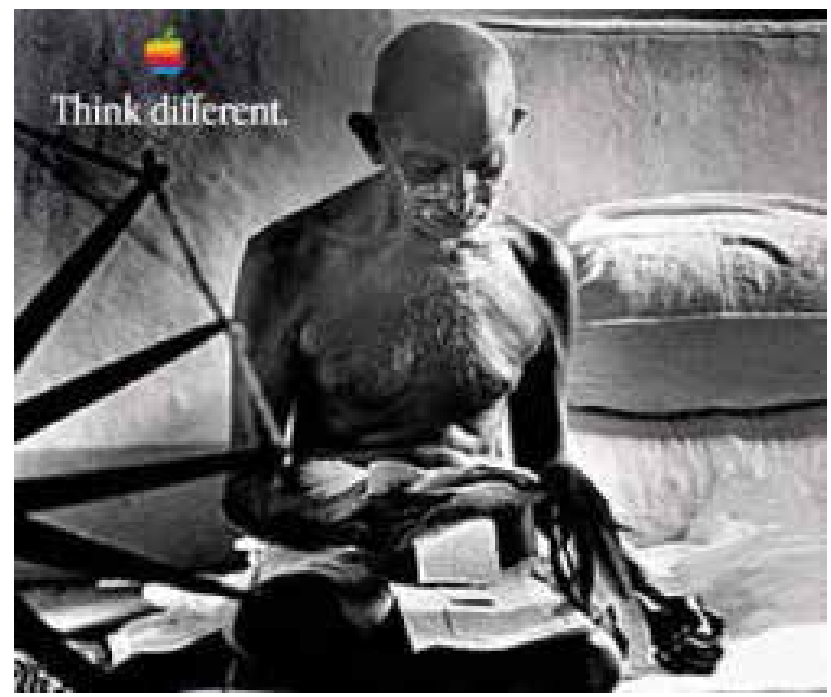

Figura 1: Anúncio Apple. Fonte: http://allthingsd.com/20091002/gandhis-headstarring-as-the-g-in-google/

O mesmo podemos dizer dos anúncios da 3M (fig. 2) e do Delas, canal feminino do IG (fig. 3), que se valem da célebre foto de Che Guevara.

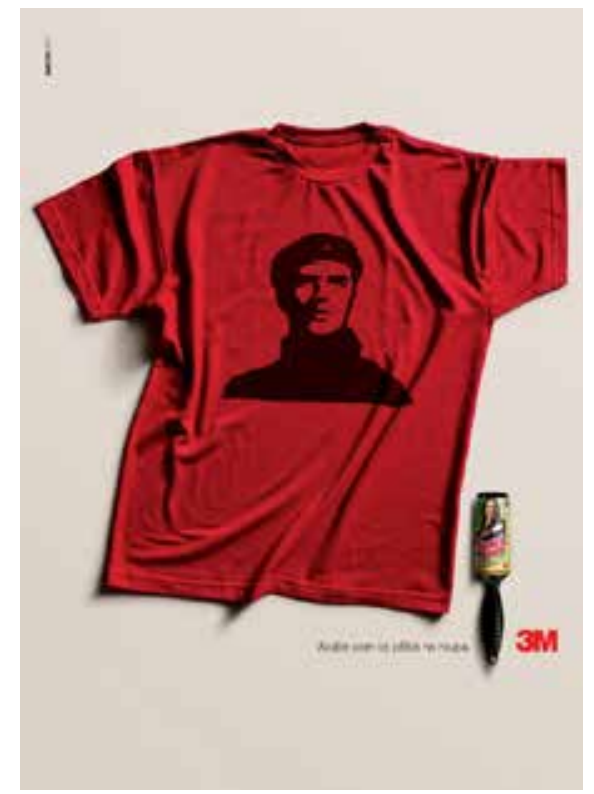

Figura 2: Anúncio 3M. Fonte: http://www.cabecadecuia.com/drops/22969/anunciomostra-che-gevara-sem-barba 


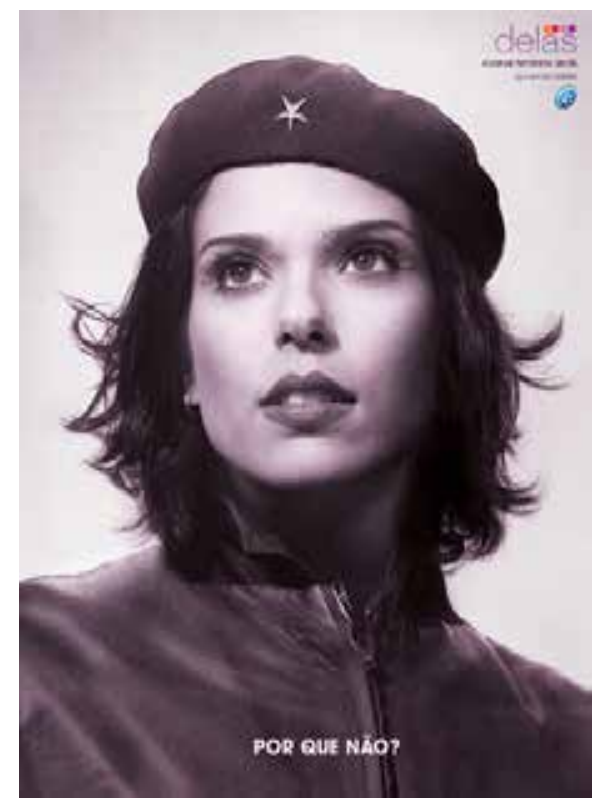

Figura 3: Anúncio Delas IG. Fonte: http://www.designergh.com.br/2013/02/porque-nao.html

Contudo, o ready-made, não obstante seja uma alternativa expressiva para algumas peças de publicidade, não o é para todas. $\mathrm{E}$ o desafio de encontrar saídas criativas em tempo exíguo, somado a outros, resulta, para os profissionais, na submissão a um clima diário - nunca aliviado - de tensão.

Nesse contexto, de ininterrupta tensão, o estresse também é contínuo. Como diagnostica Paulino (2011, p.109) em sua pesquisa, as relações de trabalho contemporâneas na publicidade se tornaram mais competitivas - ampliando a concorrência entre os profissionais e acentuando a falta de camaradagem. Fator que gera comportamentos nem sempre éticos, já relatados por Della Femina (2011) em Mad Men, e que deságua no terceiro aspecto que o conto de Fitzgerald, aqui retextualizado, nos leva a discutir: o esgarçamento geral dos afetos, especialmente no núcleo familiar.

Ainda que a erosão dos laços humanos duradouros, e a ascensão das relações efêmeras em virtude da líquida racionalidade moderna, como argumenta Bauman em Amor líquido (2004), não seja prerrogativa dos vínculos próprios ao mundo publicitário, ela se manifesta de forma vigorosa nas tribos de white collars, executivos de comunicação e 
adverstising men.

Se falta tempo para o publicitário criar, em virtude da volumosa carga de trabalho, dos prazos apertados e das pausas que rarearam, além do prolongamento da jornada, como manter engajamentos afetivos permanentes? Bauman (2004, p. 65) alerta que a razão líquida "nega direito aos vínculos e liames, espaciais ou temporais", sem contar que os relacionamentos de longa data são vistos como opressão ou dependência incapacitante. Para o sociólogo, metaforizando as uniões transitórias e as de laços fortes, o que prevalece é a primazia dos "mantos leves" e a condenação das "caixas de aço".

Podemos notar com clareza o início desse conflito afetivo, que advém da esmagadora rotina laboral, em A soneca de Gretchen, logo depois do publicitário se entregar ao novo ritmo de trabalho:

\footnotetext{
Das oito da manhã até às cinco e meia da tarde, ficava em seu escritório. Depois, meia hora no trem suburbano, onde garatujava anotações no verso de envelopes sob a luz fosca e amarelada. Às sete e trinta, seus creions, tesouras e folhas de cartolina branca eram estendidos sobre a mesa do living, e lá ficava a trabalhar, em meio de muitos resmungos e suspiros, até meia-noite, enquanto Gretchen permanecia deitada no sofá com um livro (...) À meianoite, havia sempre uma discussão sobre se ele iria ou não para a cama (FITZGERALD, 2009, p.263).
}

Em verdade, na mesma noite que Roger anuncia à mulher que vai trazer trabalho para casa nas próximas quarenta noites - "Tire quarenta sonecas e, quando despertar, tudo estará ótimo", ele lhe diz -, e antes de se lançar a esse desafio, o casal já tem uma primeira discussão, pois foram convidados a jantar por um amigo do marido, George Tompkins, e divergem se devem ou não aceitar. Por fim, Roger e Gretchen acabam decidindo ir à casa de George, que, veremos, tentará dinamitar a "caixa de aço", até então, do casamento dos Halseys.

No encontro do casal com o amigo, ficam evidentes as diferenças em relação ao estilo de vida dos dois homens: George faz exercícios físicos pela manhã (mantém em sua própria casa uma espécie de academia), cumpre uma jornada de trabalho apenas até as quatro horas e, invariavelmente, daí em diante, pratica algum esporte, condizente com a estação do ano, para relaxar, e, depois, sempre tem 
um programa ("faço alguma coisa, todas as noites, para ver-me livre de mim"). Já Roger não tem tempo para cuidar de sua forma física, acorda cedo e segue direto para o escritório, onde, ultimamente, vem trabalhando até aos domingos.

Quando George faz a descrição de sua rotina, Roger, cansado, boceja, e Gretchen o repreende, contando ao anfitrião que, nas próximas semanas, o marido continuará o trabalho noite adentro. George alerta o amigo, aquele tempo é suficiente para colocá-lo a caminho do sanatório, e, com um sorriso para Gretchen, diz, a fim de agradá-la: "A mim me parece que é sobre a esposa, mais do que sobre o marido, que recai todo o peso desses períodos malucos de excesso de trabalho" (FITZGERALD, 2009, p.261).

A noite, contudo, termina numa atmosfera de "harmonia" para 0 casal Halsey: Roger se irritou de fato com o amigo, Gretchen ficou ao seu lado, mas não deixou de pensar no convite que George Tompkins Ihe fizera no fim do jantar - passear com ele a cavalo no domingo próximo.

Nas semanas seguintes, conforme anunciara, Roger se lançou àquela nova rotina. Todas as noites, ao subir a escada de casa na ponta dos pés para dormir, encontrava Gretchen já em sono profundo. O Natal chegara e se fora, ele nem percebera o tempo passar, estava enfiado até os ossos no trabalho que, pelos seus cálculos, se metade de suas ideias vingasse, garantiria grandes lucros ao longo do ano novo. Mantinha-se tão concentrado em seu desafio que, para ele, "o mundo se convertera num sonho caótico", mas, ainda assim, não ignorava que

George Tompkins levara Gretchen a passear a cavalo, e que em outra ocasião ela saíra com ele de automóvel e passara a tarde a esquiar na colina do clube de campo. Um retrato de Tompkins, numa moldura cara, apareceu, uma manhã, na parede de seu quarto de dormir. E, certa noite, ele, escandalizado, se entregou a sobressaltado protesto, quando Gretchen saiu para ir ao teatro em companhia de Tompkins (FITZGERALD, 2009, p.263-4).

Com seu tempo monopolizado pelo trabalho, a convivência afetiva de Roger com a mulher se reduz, acelerando o processo de derretimento da "caixa de aço" do casamento dos Halseys, cujo 
fogo abrasivo George acendeu e mantém alto ao "cortejar" a esposa "abandonada" do amigo.

Como se não bastasse, embora Roger já estivesse terminando os jobs, sua saúde pede cuidados, ele é obrigado a renunciar ao café, que está Ihe causando palpitações; e um desentendimento com Gretchen, iniciado por um comentário dela sobre as contas de dezembro que não tinham como pagar, aprofunda-se quando ela anuncia que convidara George Tompkins para visitá-los àquela noite.

Impedido de "fazer sala" para o amigo, Roger, contrariado, o deixa na companhia de Gretchen e sobe para a trabalhar lá em cima. Mas aquela situação o perturba e, depois de uma hora, ele percebe que não produziu nada e retorna à sala, onde encontra a mulher e o amigo conversando sobre a "sua" saúde.

Uma discussão se origina, então, entre ele e George, quando esse busca "desqualificar" o fazer publicitário - assunto que vamos tratar a seguir, já que as tendências de um projeto vão se definindo ao longo do percurso (SALLES, 2001, p.40), assim como as notas numa jam session -, e o conflito se intensifica a ponto de Roger expulsar o amigo dali e continuar a "guerra" com Gretchen, que toma o partido do outro. Ela protesta, com os olhos cheios de lágrimas de ódio: "o único amigo que tenho, a única pessoa no mundo que gosta de mim o bastante para me tratar decentemente, é insultado pelo meu próprio marido, em minha própria casa" (FITZGERALD, 2009, p.268).

\section{Publicitários: artistas da razão ou mad men?}

Antes disso, na noite em que convidara os amigos para jantar em sua casa, George, que é um decorador de interiores de sucesso, já fizera uma crítica ao tipo de trabalho de Roger, precisamente ao seu longo expediente: "você vai acabar por se matar de tanto trabalhar. Por que não estabelece um pouco de equilíbrio em sua vida... um pouco de trabalho, um pouco de distração" (FITZGERALD, 2009, p.259).

Mas, dessa vez, na casa dos Halseys, seu ataque vai direto na essência da atividade publicitária, que consome o tempo (e a vida) dos 
criativos como Roger, e ainda resulta numa obra desprezível. George diz que Roger pensa de forma egoísta, esquecendo-se de dar atenção à mulher:

\begin{abstract}
Se você estivesse trabalhando em algum soneto maravilhoso... ou no retrato de alguma Madona ou coisa que o valha - ajuntou, fitando os cabelos à Ticiano de Gretchen -, então, claro, eu Ihe diria que prosseguisse. Mas não está. Trata-se apenas de um anúncio tolo para aumentar as vendas do tônico de cabelo Nobald, e se todos os tônicos capilares fossem amanhã lançados no oceano, o mundo não perderia coisa alguma com isso (FITZGERALD, 2009, p.266).
\end{abstract}

Roger se enfurece com o amigo, já que, de certa forma, George Tompkins atira no colo do amigo uma questão clássica, nodal, que rege o universo publicitário: a publicidade é ou não arte?

Obviamente, a polêmica divide opiniões há décadas, e não será aqui que vamos resolvê-la, nem é o nosso intuito. Mas convém mencionar três aspectos norteadores dessa discussão: 1) a sua eclosão, em virtude da arte ter sido (e continuar sendo) uma matriz da linguagem publicitária, mantendo com ela "relações promíscuas" como se expressou Chillón (1999) acerca da literatura e do jornalismo; 2 ) os procedimentos artísticos presentes no "fazer publicitário e que nutrem o antagonismo de posições"; e 3) o status do "produto" resultante de seu processo, que, para uns, seria uma manifestação artística do século XX, como sustenta Piratininga (1994) e, para outros, como George Tompkins e Toscani (1995), apenas algo tolo.

A valorização ou o desprezo para com o trabalho publicitário e seu fruto enseja, no fundo, uma representação também dual do homo que o executa: ou ele é um "artista" da razão, quer dizer, um criador consciente de que o seu talento deve lhe garantir a sobrevivência, não obstante esteja a serviço de causas corporativas; ou ele é um mad man, que, apesar das muitas instâncias a que a sua criação está submissa (Hansen, 2013), garante o seu salário, enquanto se dedica à "coisa mais divertida que alguém pode fazer vestido", como afirma Olivetto (2004, p.10).

Essa insinuação de que o trabalho publicitário é fonte de prazer, e não só em si, mas também na diversão sexual que propicia, nos remete à 
série de TV americana Mad Men, inspirada na obra de Della Femina. Em suas sucessivas temporadas, os personagens principais, publicitários de uma agência de propaganda de Nova York nos anos 1960, vivem num estado de relações promíscuas, prefigurando, naqueles tempos de "revolução sexual", o "amor líquido". E essa liquidez amorosa não se restringe aos chefes, como o diretor de criação, Don Draper, ou um dos donos da agência (e homem de atendimento) Roger Sterlling, mas se dissemina, como rizoma, pelos demais escalões.

Se o protagonista Don Draper é o exemplo notável desse comportamento, sua mulher, abandonada em casa, não por acaso começa a pensar em traí-lo nas aulas de equitação que faz para ocupar seu tempo e sua solidão - assim como Gretchen, ao atender o convite de George para passear a cavalo.

Assim, o escasso diálogo entre o casal Halsey prova que "o fracasso no relacionamento é muito frequentemente um fracasso na comunicação" (Bauman, 20104, p.31). E isso se sucede, de forma irônica, na esfera de trabalho daqueles que atuam como comunicadores sociais. Curiosamente, a esposa de Don Draper - que, aos poucos, se revela um alcoólatra -, também fica em casa, solitária, bebendo até altas horas, à sua espera, desenvolvendo estranhos comportamentos, como Zelda, mulher de Fitzgerald.

Mas, no cerne da percepção de George sobre o labor publicitário de Roger, está, indiscutivelmente, o dilema angustiante dos criativos: se, de um lado se conformam com a imagem periférica de seu trabalho na sociedade - daí porque, em seu próprio campo, vivem a se exibir -, por outro, não raro buscam produzir uma obra autoral, dedicando-se, em paralelo, à literatura, às artes plásticas, ao cinema, atividades para as quais, é óbvio, Ihes falta tempo para tirá-las do papel, como no caso de Roger.

Della Femina (2011, p.135) aborda, sem "panos leves", esse problema de reconhecimento que aflige os criativos, focando nos redatores, mas a observação vale também para os diretores de arte: 
Há um monte de redatores que fica achando que é o Faulkner ou o Hemingway. (...) As pessoas não compram a Gourmet para ler o anúncio sobre o Bombay Gin. As pessoas compram a Gourmet por causa das receitas culinárias, os anúncios são apenas um sequestro do tempo do leitor (...) Ninguém compra uma revista para ler um anúncio. Mas um monte de caras age como se fosse isso o que acontecesse.

A falta do reconhecimento artístico de suas criações, ou de certo reconhecimento restrito às medidas e referenciais pragmáticos do campo, é talvez a raiz do famigerado exibicionismo dos publicitários: se estão deslegitimados, à sombra da "alta" cultura, precisam febrilmente, em seu palco, dos mais potentes holofotes.

Na citação acima, de Della Femina, insinuam-se dois outros problemas associados a esse tipo de trabalho: 1) a publicidade opera por meio de uma lógica da interrupção ("As pessoas não compram a Gourmet para ler o anúncio sobre o Bombay Gin") e 2) também por meio de uma lógica (disfarçada) de invasão ("os anúncios são apenas um sequestro do tempo do leitor").

O desprezo de George para com a atividade profissional de Roger - um anúncio do tônico de cabelo Nobald, ou do Bombay Gin, não é nada, do ponto de vista artístico - intensifica o conflito entre a visão de mundo do publicitário e do não-publicitário. E, como mencionamos, Roger acaba por expulsar o amigo de casa. Gretchen, em reação vingativa diz "vou passear a cavalo, amanhã, em companhia de George Tompkins" e ameaça o marido: "gostaria de apanhar todo o trabalho que você fez, rasgá-lo em pedaços e atirá-lo ao fogo" (FITZGERALD, 2009, p.268-9).

Roger, no entanto, continua trabalhando naquela noite até alta madrugada - tem obrigatoriamente de cumprir prazo. E, numa tentativa derradeira de manter ainda inviolável a "caixa de aço" de seu relacionamento conjugal, no dia seguinte, antes de ir ao escritório, coloca um sonífero na xícara de café de Gretchen, corta o fio do telefone da casa e leva numa bolsa todos os sapatos da mulher, para impedi-la de se encontrar com George Tompkins.

Em seu escritório, Roger é cobrado pelo senhorio, o pagamento 
do aluguel está em atraso. O publicitário atravessa o dia "criando" e adormece lá mesmo, num sofá ao lado da mesa. Aguarda, ansiosamente, na manhã seguinte, por uma ligação de Garrod, um dos clientes de que esperava Ihe dar grandes lucros. E, quando Garrod de fato telefona, aprovando o material - e dizendo "é maravilhoso o trabalho que nos enviou. Queremos tudo o que nos mandou e muito mais, à medida que o seu escritório os puder ir produzindo" (FITZGERALD, 2009, p.274) -, Roger quase sofre um ataque cardíaco, tal a intensidade de sua catarse.

A boa notícia é um prêmio pela sua entrega ao trabalho, mas um prêmio que, se resulta em dinheiro, resulta também em mais trabalho, mais noites em claro, perpetuando uma corrente inquebrável de "exploração" que conta com a concordância não só do "senhor", mas também do próprio "escravo". Acordes que se repetem, com alguma variação, como numa jam session.

\section{Notas finais}

Ao chegar em casa para contar a novidade, Roger encontra Gretchen, que acaba de despertar, ainda arrependida da discussão que travara com o marido. Embora feliz com o contrato de quarenta mil dólares que Roger fechou com Garrod, com os vestidos novos que ela poderá comprar, Gretchen se sente confusa, dormiu duas noites seguidas - é o efeito da droga que bebeu misturada ao café -, não encontra seus sapatos, está pálida e amedrontada com seu estado.

Arrependido, Roger, sabe que é o causador do problema, e resolve chamar um médico. Então, o desenlace da história se concretiza de forma "disfórica". O médico recomenda somente repouso à Gretchen. "Se ela ficar em casa durante alguns dias e tirar umas boas sonecas, ficará logo em forma" (FITZGERALD, 2009, p.277), prescreve o doutor, sem imaginar que, nos últimos quarenta dias, ela não fez mais do que tirar sonecas, enquanto Roger trabalhava dia a dia quase sem dormir.

Aliás, por meio desse médico, o casal saberá que George 
Tompkins, com quem Gretchen iria sair para passear, teve uma crise nervosa, apesar de seu "estilo de vida" oposto ao de Roger.

Atingimos, assim, o final de nossa retextualização, ressaltando que os personagens deste conto de Fitzgerald, por analogia, representam forças atuantes, e resistentes, na esfera do trabalho publicitário. Sua presença nos permitiu - e nos permite - pensar no expediente intenso dos profissionais de Criação, cercados na atualidade por muita tecnologia e, não obstante, como revela a pesquisa de Paulino (2011, p.88), cientes de que seu trabalho está essencialmente vinculado às relações interpessoais.

Neste contexto, e seguindo as conclusões de Paulino (2011), notamos que as mudanças no mundo do trabalho publicitário resultaram estruturalmente em poucas variações, uma vez que nele prevalece a forte concorrência entre os colegas (como a de Roger e George, ainda em que de outro gênero), as jornadas de trabalho extensas (iguais as de Roger) e o ritmo acelerado (como o de George), que colaboram inegavelmente para a tensão e o estresse dos profissionais dessa área.

Falta, sobretudo, aos "criativos", nas palavras de Paulino (2011, p. 109), "abertura para o acesso a produções culturais que permitam vislumbrar outros pontos de vista. Visões de mundo diferenciadas". Visões que, para nós, enquanto Gretchen dorme, são negadas aos publicitários pela realidade diária de seu trabalho.

\section{Referências bibliográficas}

BAUMAN, Zygmunt. Amor líquido. Sobre a fragilidade dos laços humanos. Rio de Janeiro: Zahar, 2004.

BERGER, John. Modos de ver. Barcelona: Gustavo Gilli, 1975.

BETTETINI, Gianfranco. La conversación audiovisual. Barcelona: Cátedra, 1996.

CARRASCOZA, João Anzanello. Do caos à criação: processo criativo, plágio e ready-made na publicidade. São Paulo: Saraiva, 2008.

E o vento mudou... As transformações do trabalho 
publicitário. In: CASAQUI, Vander; LIMA, Manolita Correia; RIEGEL, Viviane (orgs.). Trabalho em publicidade e propaganda. História, formação profissional, comunicação e imaginário. São Paulo: Atlas, 2011.

CASAQUI, Vander; LIMA, Manolita Correia; RIEGEL, Viviane (orgs.). Trabalho em publicidade e propaganda. História, formação profissional, comunicação e imaginário. São Paulo: Atlas, 2011.

CHILLÓN, Albert. Literatura y periodismo - Una tradición de relaciones promiscuas. Barcelona: Universitst Autònoma de Barcelona, 1999.

DUAILIBI, Roberto. Cartas a um jovem publicitário. Nem tudo é festa. Como vencer na vida fazendo muita força! Rio de Janeiro: Elsevier, 2006.

FEMINA, Jerry Della. Mad Men. Comunicados do front publicitário. Rio de Janeiro: Record, 2011.

FITZGERALD, F. Scott. Seis contos da era do jazz e outras histórias. Rio de Janeiro: José Olympio, 2009.

FUENTES, Carlos. Eu e os outros - Ensaios escolhidos. Rio de Janeiro: Rocco, 1989.

HANSEN, Fabio. (In)verdades sobre os profissionais de criação: poder, desejo, imaginação e autoria. Porto Alegre: Entremeio, 2013.

KLEE, Paul. Diários. São Paulo: Martins Fontes, 1990.

MALLARMÉ, Stéphane. Um lance de dados jamais abolirá o acaso. In: Campos, Augusto de, Pignatari, Décio e Campos, Haroldo de. Mallarmé. $3^{a}$ ed., São Paulo: Perspectiva, 1991.

OLIVETTO, Washington. Com alguma razão e certa sensibilidade. In: CARRASCOZA, João Anzanello. Razão e sensibilidade no texto publicitário. São Paulo: Saraiva, 2004.

OSTROWER, FAYGA. Criatividade e processos de criação. Petrópolis: Vozes, 1978.

Campus, 1990.

Acasos e criação artística. Rio de Janeiro:

PAIXÃO, Fernando. Arte da pequena reflexão - Poema em prosa contemporâneo. São Paulo: Iluminuras, 2014.

PAULINO, Roseli Aparecida Fígaro. Perfil sociocultural dos comunicadores: conhecendo quem produz a informação publicitária. In: CASAQUI, Vander; LIMA, Manolita Correia; RIEGEL, Viviane (orgs.). Trabalho em publicidade e propaganda. História, formação profissional, comunicação e imaginário. São Paulo: Atlas, 2011.

PIRATININGA, Luiz Celso de. Publicidade: arte ou artifício? São Paulo: T.A.Queiroz, 1994. 
RAMOS, Ricardo. Do reclame à comunicação - Pequena história da propaganda no Brasil. São Paulo: Atual, 1985.

ROCHA, Everardo P. Guimarães. Magia e capitalismo - Um estudo antropológico da publicidade. 2a . ed. São Paulo: Brasiliense, 1990.

SALLES, Cecilia Almeida. Gesto inacabado: processo de criação artística. $2^{a}$. ed., São Paulo: FAPESP/Annablume: 2001.

TOSCANI, Oliviero. A publicidade é um cadáver que nos sorri. Rio de Janeiro: Ediouro, 1995. 


\section{INFÂNCIA E MÍDIA: BREVE REVISÃO DE UM CAMPO EM DISPUTA}

\section{CHILDHOOD AND MEDIA: A}

Edição v.35 número 3 / 2016-17

Contracampo e-ISSN 2238-2577 Niterói (RJ), v. 35, n. 3

dez/2016-mar/2017

A Revista Contracampo é uma revista eletrônica do Programa de Pós-Graduação em Comunicação da Universidade Federal Fluminense e tem como objetivo contribuir para a reflexão crítica em torno do campo midiático, atuando como espaço de circulação da pesquisa e do pensamento acadêmico.

\section{BRIEF REVIEW OF A FIELD IN DISPUTE}

\section{RENATA OLIVEIRA FERRAZ}

Doutoranda em Comunicação e Cultura, na linha de pesquisa Mídia e Mediações Socioculturais, com Bolsa Faperj Aluno Nota 10, pela Universidade Federal do Rio de Janeiro, onde concluiu o mestrado (2011) e a graduação em Jornalismo (2004). Membro do corpo de colaboradores da revista ECO-Pós e estagiária docente na Escola de Comunicação da UFRJ. Tem experiência profissional na área de Comunicação, em mídia impressa, online e eletrônica. Os interesses de pesquisa se concentram nas áreas de infância, juventude, subjetividades contemporâneas, culturas urbanas, maternidade e mídia. Brasil.

renatactomaz@gmail.com

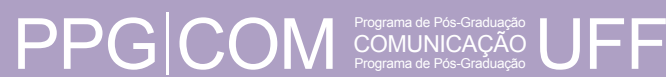

AO CITAR ESTE ARTIGO, UTILIZE A SEGUINTE REFERÊNCIA:

TOMAZ, Renata Oliveira. Infância e mídia: breve revisão de um campo em disputa. Contracampo, Niterói, v. 35, n. 03, dez. 2016/ mar. 2017.

Enviado em 21 de março de 2016 / Aceito em: 05 de novembro de 2016. 


\section{Resumo}

O objetivo deste artigo é identificar as principais perspectivas a partir das quais a infância vem sendo compreendida enquanto construção social na sua relação direta com a mídia. O trabalho consiste no levantamento da produção acadêmica, nos últimos dez anos, através de consultas no Portal de Periódicos da Capes e na Plataforma Scielo. De acordo com o levantamento realizado, as análises que investigam a relação entre mídia e infância indicam que os elementos constituintes da infância são fabricados pelas sociedades por meio de verdades que não são desveladas e sim produzidas nas disputas simbólicas.

\section{Palavras-chave}

Revisão de literatura; infância e mídia; estudos da infância

\section{Abstract}

The purpose of this article is to identify the main perspectives from which childhood has been understood as a social construction in its direct relationship with the media. The work consists of a survey of academic production in the last ten years, through search in the Portal de Periódicos da Capes (Capes Periodics Portal) and Plataforma Scielo (Platform Scielo). According to the survey, the analysis that investigate the relationship between media and childhood indicate that constituent elements of childhood are built by the societies through truths that are not unveiled, but produced in the symbolic disputes.

\section{Keywords}

Literature review; childhood and media; childhood studies 


\section{Introdução}

As imagens das crianças famosas, consumidoras, cidadãs, em situação vulnerável, trabalhadoras ou empreendedoras se multiplicam. E suas vozes, carregando seus desejos e vontades, necessidades e demandas, ecoam cada vez mais em diferentes instâncias das sociedades. Um dos indicadores dessa presença das crianças é a produção de saberes sobre os primeiros anos da vida, constituídos em narrativas que as situam em determinadas posições de sujeito (HALL, 2009), produzindo subjetividades. Disciplinas provenientes de campos distintos de conhecimento se inserem paulatinamente nos estudos da infância e produzem chaves teóricas e explicativas que nos ajudam a compreender os sentidos historicamente atribuídos e socialmente construídos nas concepções de infância.

Entender essa crescente visibilidade e audibilidade das crianças passa necessariamente por considerar os usos que elas fazem dos meios de comunicação. Nesse sentido, o objetivo deste trabalho é identificar as principais perspectivas a partir das quais a infância vem sendo compreendida, particularmente na sua relação direta com a mídia. A multiplicidade de áreas do conhecimento pesquisando tal relação sinaliza a onipresença da mídia, a qual Sodré (2012, p. 21-28) chamou de quarto bios, indicando como as mais distintas experiências da vida, incluindo a da criança, têm sido mediatizadas. Nesse sentido, este trabalho também busca entender como os processos comunicacionais atravessam a produção contemporânea da infância, e, assim, averiguar se esta construção pode ser considerada um problema teórico para o campo da comunicação. O trabalho consiste no levantamento da produção acadêmica registrada, nos últimos dez anos, através de consulta no Portal de Periódicos da Capes $^{1}$ e na Plataforma Scielo². O texto aborda, no primeiro tópico, a construção da amostra utilizada

1 A consulta foi feita por meio do acesso remoto disponibilizado pela UFRJ para o corpo docente e discente. Disponível em: http://www.periodicos.capes.gov.br/. Último acesso em 29 de julho de 2015.

2 Consulta realizada no site http://www.scielo.org/php/index.php. Último acesso em 28 de julho de 2015. 
para a análise; em seguida, faz uma breve recuperação da formação histórica dos principais paradigmas da infância; e, só então, apresenta os principais eixos temáticos sobre os quais os estudos sobre infância e mídia têm sido realizados.

\section{Coleta de dados}

A primeira opção para fazer essa pesquisa seria o Banco de Teses e Dissertações da Capes, mas o fato de o acervo, na época da coleta, estar limitado à produção de 2011 em diante dificultou o levantamento ${ }^{3}$. Primeiro porque a consulta abarcaria um período inferior a quatro anos, que considero pequeno para avaliar as continuidades e rupturas na construção discursiva da infância. Segundo porque é importante entender como essa produção acontece no campo da comunicação e, nesse breve período, de um total de cinquenta teses e dissertações cuja temática era infância e mídia, foram encontrados apenas cinco trabalhos provenientes de programas de pós-graduação em comunicação. A segunda opção foi, então, o Portal de Periódicos da Capes. A busca com as palavras "mídia e infância", no campo assunto, nos últimos dez anos, encontrou onze textos. Embora o escopo fosse maior do que o do banco, a dificuldade em mapear as principais temáticas e abordagens continuou. Por essa razão, optei por fazer a busca no campo assunto com as palavras "childhood e media", usando alguns filtros para refinála. Sendo assim, o levantamento deixou de ser no campo brasileiro e se tornou mais amplo.

Na primeira tentativa, sem intervalo de tempo, a pesquisa listou 1.170 textos, publicados entre 1960 e 2015. Ao diminuir o intervalo para os últimos dez anos (2005 a 2015), o número de trabalhos caiu para 920, o que mostra a concentração da produção sobre mídia e infância nos anos 2000. Em seguida, utilizei um filtro que privilegiou as temáticas "Internet, mass media effects", "Television advertising", 
"Mass media e media"4. O número de trabalhos caiu, então, para 143 - com uma maior concentração entre os anos de 2010 e 2012. Foram descartados os textos de mídia impressa como artigos de jornais e arquivos de áudio provenientes de conferências, os quais também compunham o resultado da busca. Esses cortes representaram cerca de $30 \%$ do total. Os textos eram maiormente artigos, mas também havia teses e dissertações. Em seguida, foram identificados os trabalhos em português. Uma consulta com as palavras "mídia e infância", "media e childhood", na Plataforma Scielo, permitiu identificar trabalhos brasileiros que não haviam aparecido na busca do Portal de Periódicos. Os resultados de ambas pesquisas somaram quatorze trabalhos publicados por brasileiros, em português, nos últimos dez anos, com a temática infância e mídia. Utilizei esse recorte, feito dentro da amostra maior, para averiguar se a produção brasileira refletia de modo geral a produção mais ampla ou se apresentava alguma tendência específica.

A análise começou com a organização dos trabalhos, dispostos dos mais recentes para os menos recentes nas seguintes categorias: autores, título, temática/problema central, natureza da publicação (artigo, tese etc.) e campo disciplinar. A descrição da temática central foi feita a partir da leitura de títulos, resumos e palavras-chave, por meio da qual foi possível elencar as principais abordagens do assunto infância e mídia, bem como suas matrizes teórico-metodológicas. Os dados relacionados ao campo disciplinar revelaram como a produção de saberes relativos à infância não é de uma área do conhecimento, mas se vale cada vez mais de diferentes perspectivas que deem conta de sua inquestionável complexidade. Conforme defende Castro (1998, p. 12), "faz-se necessário reconhecer a impossibilidade de descrever e analisar tal experiência do ponto de vista de uma única área disciplinar do conhecimento" e empreender "um esforço de se pensar a questão da infância fora dos limites estritos de uma única área de conhecimento"

4 A fim de otimizar os resultados, privilegiei no meu filtro temáticas que indicavam estudos cuja discussão central passava pelas mídias massivas e digitais e dispensei aquelas que concentravam artigos com outra ênfase, tais como "Strategies", "Preeschool children", "Foreing countries", "Early adolescence" e "Early childhood education". 
(idem). Desse levantamento, realizei uma análise para entender a que matrizes teórico-metodológicas a produção da temática infância e mídia está ligada. Que regimes de verdade estão operando nas definições de infância? É possível entender a infância como um problema teórico da comunicação? Antes de chegar a essas especificidades, segue uma breve recuperação histórica das teorias que, ao longo da Modernidade, têm sido construídas para narrar a infância e, assim, produzir sentidos que estão em constante disputa nas arenas contemporâneas, principalmente a midiática.

\section{Infâncias: discursos constituídos em relações de poder}

Stearns (2006) considera a infância uma narrativa do papel social da criança em determinado contexto. Para ele, os diferentes papeis produzem diferentes narrativas e, portanto, diferentes infâncias. Gómez-Mendonza e Alzate-Piedrahíta (2014, p. 79) afirmam que a infância tem seu início quando "seus narradores" começam a narrá-la. Eles citam filósofos do século XVIII, como Locke, que se referia à criança como "tábua rasa" ou "página em branco", indicando a necessidade de ela ser "preenchida", ou ainda produzida, pelos adultos. Com uma produção mais densa, Rousseau ([1762]2014, p. 119-121) acreditava que as crianças podiam raciocinar, mas não racionalizar, motivo pelo qual chamou a infância de "sono da razão".

É importante entender, entretanto, que a produção das narrativas que constroem a ideia de infância responde a uma articulação de forças, a relações de poder que perpassam as instituições (FOUCAULT, 1979). A compreensão do que é a infância nos dois últimos séculos não reside na descoberta de verdades sobre a criança, mas na produção dessas verdades em um contexto social, histórico, cultural e político. Nessa perspectiva, este tópico vai mostrar como o paradigma desenvolvimentista da infância se tornou hegemônico na virada do século XX e como está deixando de sê-lo. Ambos movimentos estão 
ligados, respectivamente, à ascensão e enfraquecimento da psicologia como saber dominante do indivíduo. Suas origens remontam ao final do século XIX, quando, segundo Warde (2014), o psicólogo estadunidense G. Stanley Hall (1846-1924) se torna o fundador do child study.

Diferente dos childhood studies, os quais serão abordados mais à frente, o child study era fruto de um empreendimento teórico, social e político de Hall para cientifizar os saberes da infância a partir da reunião de diferentes disciplinas, as quais dariam embasamento à pedagogia e esta, por sua vez, seria a definidora das práticas escolares. Com base em uma perspectiva teórica evolucionista, ele defendia que a criança era uma espécie de elo da cadeia evolutiva, repositório biológico de elementos valiosos para o desenvolvimento humano.

Dentre os esforços dele, estava a publicação do Pedagogical Seminary, criado por Hall na época em que presidia a Clark University, onde os debates surgiram. O periódico também se tornou um campo de embates nas disputas por legitimar as vozes que falariam em nome da criança e da infância, evidenciando os pilares do child study. Warde acrescenta a estes elementos teóricos e acadêmicos uma estratégia política: o uso da National Education Association (NEA) como arena de discussão para as questões da infância e da educação, onde nasceram, no início dos anos 1880 , as reivindicações de uma base científica para a pedagogia.

Uma das formas de pressionar a comunidade acadêmica em relação a isso foi publicar artigos (cerca de 30, entre os anos de 1883 e 1893) com relatos de experimentos. Um número cada vez maior de profissionais envolvidos com a infância, as crianças e a educação articulava-se, publicando ou militando "em favor de reformas educacionais pautadas em estudos da criança, ao mesmo tempo em que outros psicologistas estavam sendo cativados para pesquisas empíricoexperimentais em torno do desenvolvimento e da aprendizagem da criança" (WARDE, 2014, p. 253). Em 1893, Hall publicou Child Study as a basis for psychology and psychological teaching e Child study: the basis of exact education. Até então, ele se referia ao campo como 
"study of children". A mudança de nome para child study, embora pareça sutil, faz importantes marcações:

\begin{abstract}
substituiu a referência empírica pré-conceitual - crianças: indivíduos particulares e, por isso, variáveis - pela referência conceitual a um objeto determinado - a criança: sujeito universal e, por isso, igual a si mesmo. Com essa aparentemente simples troca de nome, Hall inscreveu um novo campo de conhecimentos nos marcos do saber especializado, científico: 1) demarcou o território que separaria a nova produção disciplinada da produção prédisciplinar ou não ainda disciplinada; 2) estabeleceu a base da 'correta educação' e 3) definiu, para ele mesmo ocupar, o lugar de pai fundador daquele novo saber (WARDEN, 2014, p. 253).
\end{abstract}

Apesar de Hall ter se empenhado para reunir diferentes disciplinas, amparado em uma perspectiva evolutiva de desenvolvimento, o que ele acabou por fazer foi contribuir para que a psicologia se tornasse a base do child study. Segundo Warde, o campo em si não teve vida longa, mas o entendimento da psicologia como lugar de produção de verdades sobre a infância se firmou e prevaleceu ao longo do século $X X$, nutrindo um paradigma desenvolvimentista da infância cujo objetivo final era ser adulto. Nessa compreensão, a criança é vista a partir de sua falta em relação ao adulto, como alguém que ainda não é, inacabada.

Na segunda metade do século XX, as ciências cognitivas começam a minar essa compreensão por meio de estudos que comprovam a inexistência de diferença entre o cérebro da criança e do adulto. E, mais recentemente, na virada do século XXI, os procedimentos que possibilitam o mapeamento do cérebro permitiram explorar as múltiplas possibilidades não só dos adultos, mas especialmente das crianças (GÓMEZ-MENDOZA; ALZATE-PIEDRAHÍTA, 2014, p. 80). Entretanto, foram as ciências sociais, particularmente a antropologia e a sociologia, que empreenderam uma crítica contundente à psicologia do desenvolvimento enquanto lançavam as bases para o surgimento de uma nova sociologia da infância, que se tornou central na formação de um campo específico: os childhood and children studies.

Para Sarmento (2008, 2009), a formação desse campo só foi possível graças a algumas condições de possibilidade, dentre as quais 
ele destaca: 1) a desconstrução da "produção pericial da infância pelas ciências do indivíduo" (campo psicológico), ancorada sobretudo na visão desenvolvimentista da criança; 2) uma crítica à própria sociologia, do ponto de vista do conceito de socialização, o qual contribui para a ocultação da criança (BOLLO-BOUVIER, 2005; CORSARO, 2011); 3) a virada subjetiva da sociologia que acabou por contemplar assuntos antes mais pertinentes a disciplinas como a psicologia; 4) a importância das crianças frente à diminuição das taxas de natalidade, ocasionando isso talvez a valorização de sua presença/ausência. Sirota (2001) defende que o ponto de partida da sociologia da infância é a oposição a uma tradição durkheimiana de conceber a infância, em que a criança é vista como socializada passivamente pelo adulto. Entretanto, a socióloga francesa acredita que os embates teórico-metodológicos, acadêmicos e, em certa medida, políticos foram fundamentais para solidificar uma nova perspectiva de estudos da infância.

Segundo a autora, no final dos anos 1980 as associações americana e internacional de sociologia criaram departamentos e núcleos específicos de sociologia da infância. Pouco mais tarde, na própria GrãBretanha, realizaram-se, a partir de 1986, workshops sobre etnografia da infância, seguidos da criação da rede "Criança e Sociedade", em Londres e Kele. Também neste ano, pesquisadores ingleses lançaram a revista, Sociological Studies of Child Development, mais tarde chamada de Sociological Studies of Children. Ainda no final dos anos 1980 e início dos anos 1990, surgem dois programas de pesquisa: "A infância como fenômeno social", em Viena, e o "Programa de Pesquisa sobre a criança de 5 a 16 anos", em Londres. Ambos se preocupavam em desenvolver teorias e métodos de pesquisa que enxergassem a criança como um ator social e a infância como uma construção da sociedade.

Embora aparentem mudanças de termos disciplinares, as palavras sociedade, fenômeno social, crianças (plural) demonstram a reivindicação de uma mudança radical no modo de investigar a infância. O uso plural, de child study para childhood studies, por exemplo, indica a compreensão de que os saberes relativos à infância 
não pertencem à psicologia, mas circulam em diferentes campos disciplinares. A criança passa a ser tomada em suas especificidades sociais (raça, etnia, gênero, classe, escolaridade etc.). A multiplicidade de experiências produzidas por essas condições, entende-se, resulta em uma multiplicidade de infâncias, razão pela qual esse período da vida não deve ser compreendido como natural ${ }^{5}$, mas como uma construção social.

As ciências sociais, então, desde o final do século passado, têm minado a perspectiva desenvolvimentista da infância e promovido uma perspectiva das competências (CASTRO, 2013), uma concepção que não vê a criança por meio daquilo que ela não tem em relação ao adulto, mas a partir das diferenças que permeiam as alteridades, inclusive entre adultos. A criança não precisa crescer para ser alguém. Ela está sendo, tornando-se, agindo no mundo, produzindo formas de estar e ser, produzindo cultura e sendo produto dela. O objetivo desse tópico, então, foi mostrar que as narrativas da infância não correspondem a uma verdade da infância, mas a regimes de verdade que definem, mediante relações de força e poder, a experiência dos primeiros anos de vida.

\section{Infância, mídia e produção de sentido}

Embora todos os continentes estejam de certa forma representados no corpus analisado, há uma predominância de trabalhos provenientes de países de língua inglesa como Estados Unidos e Austrália. A maior parte dos trabalhos vem da grande área das ciências humanas, principalmente da psicologia e da educação. Em seguida, apareceram trabalhos de disciplinas como medicina, nutrição e enfermagem; e, por fim, aqueles originários da área de ciências sociais e sociais aplicadas. A recuperação histórica feita acima foi necessária

5 Isso não significa negar o caráter biológico da infância que é, de fato, um tempo em que a criança está crescendo - aprende a falar, troca a dentição, engatinha para andar, corre etc. A questão reside no fato de esses processos serem avaliados e geridos de formas distintas em diferentes culturas, o que demonstra um caráter social e cultural da infância. 
para que a produção dos últimos dez anos pudesse ser identificada em suas matrizes teórico-metodológicas e, assim, compreendida em seu contexto. Os trabalhos analisados foram organizados em torno de dois eixos temático-teóricos: 1) o que a mídia faz com as crianças e 2) o que as crianças fazem com a mídia. Apesar de eles serem insuficientes para contemplar a diversidade e as nuances das produções, ajudam a vislumbrar os modos mais recorrentes de conceber a infância em sua relação direta com a mídia.

\subsection{0 que a mídia faz com as crianças: as representações e os efeitos}

Esse conjunto de trabalhos pode ser dividido em dois grupos. No primeiro, em menor quantidade, estão aqueles que tratam das representações, indicando como a mídia retrata as crianças e como constrói a realidade da infância. Dentre eles, há os que questionam estereótipos (DENOV, 2012; HOFFMAN, 2012; WELLS, 2007), apontam a produção de subjetividade (FISCHER, 2008; TOMAZ, 2014), indicam como os diferentes discursos interpelam as crianças (VERGARA, VERGARA, 2012; MONTGOMERY et al., 2012) e sinalizam a normatização da infância (MAHER et al., 2010; ZIVKOVIC et al., 2010). Os trabalhos mostram que a mídia produz determinadas imagens da criança e da infância que são utilizadas para construir realidades e, portanto, verdades.

O segundo grupo é formado por trabalhos que se preocupam em mensurar os efeitos da mídia sobre as crianças e avaliar a sua vulnerabilidade diante dos meios de comunicação. Dentre as questões tratadas e consideradas diretamente vinculadas ao impacto da exposição das crianças à mídia estão o aumento de peso e a obesidade infantil (HARVEY, 2013; YU, 2012), o consumismo irrefletido (HILL, 2011) e o comportamento violento (MARTÍNZES et al., 2011; ERWIN, MORTON, 2008). Essa perspectiva se aproxima, como vimos, de uma tradição norte-americana de pesquisa voltada para a psicologia do 
desenvolvimento, com ênfase na criança individual, nos estudos de efeito e nas metodologias quantitativas (LEMISH, 2015). Percebidas de um ponto de vista da falta, as crianças são pensadas como passivas, inocentes e vulneráveis.

De acordo com Lemish (2015, p. 4), a visão desenvolvimentista permitiu que, em relação à mídia, as crianças fossem consideradas "incapazes de entender o conteúdo midiático como o adulto; não eram imunizadas contra seu efeito negativo; e, diferente dos adultos, eram ingênuas e facilmente persuadidas". A ideia, então, de que a criança está em um processo evolutivo de desenvolvimento, que poderá ser gravemente atingido pelos efeitos danosos da mídia, estabelece uma relação desigual de forças, produzindo uma infância vulnerável e carente da intervenção adulta (BAIOCCO et al., 2009) e da regulação da mídia pelo Estado (HARVEY, 2013). Isso não significa dizer que as tecnologias e a mídia em si produzem subjetividade, mas que compõem o conjunto de condições de possibilidade para a criança ser.

Desse modo, os pesquisadores voltados para essa temática remetem à matriz desenvolvimentista da infância. A crítica a essa perspectiva, entretanto, não pode anular a importância dos assuntos debatidos. Ou seja, deixar de pensar a criança como passiva não significa deixar de pensar a sua exposição à mídia e os modos como isso a afeta. Nesse sentido, surgem trabalhos que retomam temáticas caras aos estudos de efeito e propõem uma nova leitura. É o caso da erotização da infância, creditada em muito aos produtos midiáticos. Ao investigála, Thompson (2010) defende a necessidade de superar a relação quase automática entre sexualização da criança e mídia, ouvindo as crianças e deixando de basear questões e respostas no que chama de visão adultocêntrica. Ainda sobre o assunto, Bragg et al. (2011) afirmam que é preciso haver uma discussão mais complexa, uma vez que as respostas comumente encontradas aparentam simplificar a discussão. A compreensão da criança como um ator social, portanto, interfere diretamente nos modos de pesquisar a infância na sua relação com a mídia, reconfigurando as abordagens, até então, predominantes. 


\subsection{0 que as crianças fazem com a mídia: as produções simbólicas e materiais}

A maior parte dos trabalhos da última década, entretanto, é fruto de pesquisas preocupadas com a ação da criança a partir da sua relação com a mídia. Eles podem ser divididos também em dois grupos, sendo o primeiro composto por estudos que discutem os sentidos produzidos pelas crianças a partir do consumo que fazem de produtos da indústria cultural. Há uma predominância de tomar a criança na sua condição de consumidora, dotada de agência, na medida em que consome com uma intenção (TRICE, 2010). Por meio de estudos de recepção em boa parte dos casos, essas pesquisas avaliam, por exemplo, como as crianças, a partir de sua relação com a mídia, constroem realidade (DE LA ROCHE, 2012), ressignificam identidades ofertadas (SIMPSON, 2013; WOHLWEND, 2012), promovem usos distintos da produção audiovisual e musical (CHACÓN, MORALES, 2014; FERNÁNDEZ, 2010; PEREIRA, 2006), bem como dos desenhos animados (ROCHA, 2012; SALGADO, 2012).

O segundo grupo é formado por investigações que procuram enxergar as crianças para além de sua condição de consumidoras, entendendo-as como produtoras de cultura, não apenas na sua compreensão simbólica, mas também material. Dentre as temáticas exploradas estão o uso das novas tecnologias pelas crianças para a produção de textos escritos, filmes e ficção (DEFAUW, 2013; LENTERS, WINTERS, 2013; SCHNEIDER et al., 2014; YOUNG, RASINSKI, 2013), a formulação de novas maneiras para brincadeiras conhecidas (BRENT, 2011; SIQUEIRA et al. , 2012) e de novos modos de letramento (O'MARA, LAIDLAW, 2011). O que se pode depreender desses dois grupos de trabalhos é que a relação entre infância e mídia é tratada em uma articulação, de modo que a produção de sentidos é mediada, não dada (HALL, 1980). Há uma intencionalidade de ambas as partes, as quais se manifestam em sucessivos processos de negociação simbólica.

Para alguns desses pesquisadores, uma vez sabendo como 
as crianças produzem sentido, pode ser possível torná-las uma audiência mais crítica (CHACÓN, MORALES, 2014; SÁNCHEZCARRERO, SANDOVAL-ROMERO, 2012) e, assim, avançar da condição de consumidora para a de produtora. Essas pesquisas apontam para duas dimensões em que a criança se constitui como sujeito da ação e não apenas objeto de cuidados. Nos dois grupos ela é consumidora da cultura midiática, mas no segundo, além dessa condição, ela também é produtora de uma cultura participativa e, nesse sentido, concebida na condição de cidadã (POYNTZ, HOECHSMANN, 2011). Sendo assim, esses trabalhos procuram entender os processos pelos quais as crianças se relacionam com os produtos midiáticos e atribuem sentidos novos ao mundo, às relações, aos ideais, interferindo nos modos de pensar, produzindo, portanto, cultura - ao mesmo tempo em que são produzidas por ela. As narrativas que resultam desses saberes desafiam uma concepção moderna de infância, segundo a qual as crianças são incompletas em relação aos adultos, sofrem uma socialização passiva e realizam um consumo irrefletido. Elas sinalizam uma compreensão da ação das crianças no mundo como atores sociais.

\subsection{Infância e mídia: um recorte da produção brasileira}

De todo o material analisado, quatorze foram produzidos no Brasil. São artigos, dissertações e teses que indicam quem está pesquisando infância e mídia, em que campos e a partir de que perspectivas teórico-metodológicas. O levantamento (GRÁFICO 1) mostrou também que a educação é o campo que mais trata a temática, enquanto na comunicação havia apenas um trabalho (TOMAZ, 2014)6. A maior parte dessa produção está no Sudeste (GRÁFICO 2), onde de fato se

6 O fato de os trabalhos sobre mídia e infância produzidos nos programas de pós-graduação em comunicação no Brasil não estarem aparecendo em bases como o Portal de Periódicos e o Scielo não significa que não haja pesquisadores estudando o assunto. Acompanho uma produção crescente na área, composta por coletâneas, dissertações e teses, especialmente no período analisado (ALCÂNTARA, GUEDES, 2014; BARBOSA, 2012; DORETTO, 2013; FURTADO, 2013; ORLANDI, 2012; PEREIRA, 2016; SAMPAIO, CAVALVANTE 2006; SOBRAL, 2014; VIVARTA, 2009; TOMAZ, 2011). Entretanto, esses trabalhos não apareceram nas bases pesquisadas, o que pode estar indicando uma necessidade não só de produção, mas especialmente de publicação. 
concentra o maior contingente docente e discente de pós-graduação do País.

Gráficos 1 e 2: distribuição da produção brasileira na temática infância e mídia

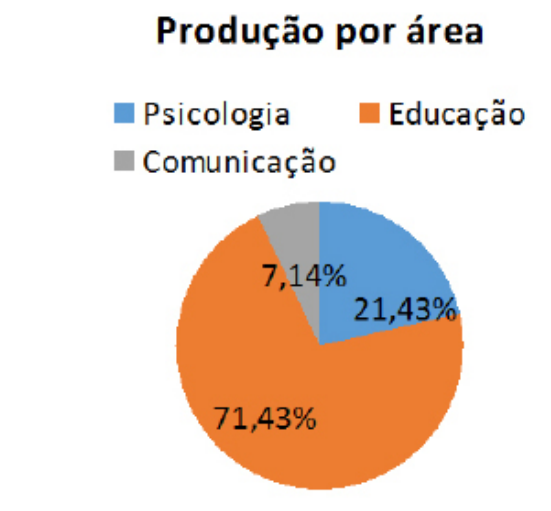

Gráfico 1 - Áreas do conhecimento

Fonte: Portal de Periódicos da Capes e Plataforma Scielo

\section{Produção por região}

aul $\quad$ Sudeste

nordeste $\|$ Centro-Oeste

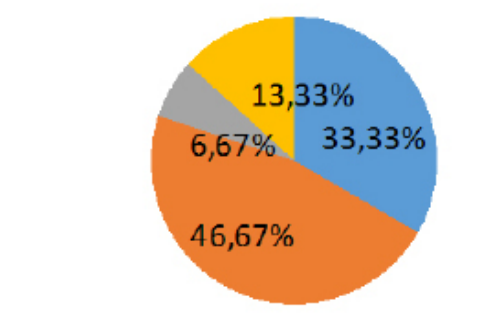

Gráfico 2 - Áreas do conhecimento

Fonte: Portal de Periódicos da Capes e Plataforma Scielo

A maioria das pesquisas privilegia o protagonismo da criança, enfatizando suas produções simbólicas e materiais feitas a partir da mídia (DE LA ROCHE, 2012; SALGADO, 2012; SIQUEIRA et al., 2012). Apenas dois trabalhos se dedicaram à produção da própria mídia (CECHIN, SILVA, 2012; TOMAZ, 2014) e, nesse sentido, às representações dela advindas. Havia, ainda, três trabalhos voltados a compreender o que se pode chamar de infância contemporânea através da relação das crianças especialmente com a mídia (CARRIJO, 2012; MOMO, COSTA, 2010; SALGADO et al., 2005). Essa amostra de estudos sobre mídia e infância realizados no Brasil revela um esforço crescente em questionar o consumo midiático passivo da criança. Através de estudos de recepção e de inspiração etnográfica, sobretudo, os pesquisadores procuram evidenciar as leituras criativas das crianças e os modos pelos quais elas fazem uso das mídias, especialmente as eletrônicas.

De maneira geral, essas pesquisas reconhecem, em primeiro lugar, que as crianças, na condição de consumidoras, também se tornam interlocutoras. As investigações ajudam a compreender que, ao 
interpelar as crianças por meio de produções culturais, os dispositivos midiáticos permitem que elas se percebam no cenário social e, assim, construam visões de mundo. As práticas de consumo das crianças revelam realidades construídas por elas a partir de negociações simbólicas travadas cotidianamente.

Em segundo lugar, esse recorte nos mostra que uma cultura cada vez mais da imagem e cada vez menos letrada amplia paulatinamente a presença e a participação da criança. Ao abordar a infância em sua relação direta com a mídia, esses estudos se concentram nos desenhos animados, nos games, nos filmes infantis e na publicidade, entre outros produtos. Seu consumo, pelas crianças, é basicamente através da imagem e dispensa o domínio de códigos mais complexos de leitura. Essa possibilidade dá às crianças acesso à arena pública da mídia, tornando-as centrais em tomadas estratégicas de decisão.

Por fim, essas pesquisas admitem que o acesso a novas mídias e tecnologias não determina, mas amplia as possibilidades de as crianças produzirem histórias, novas brincadeiras, vídeos, apresentações etc. Trata-se de uma produção simbólica e também material, por meio da qual as crianças interpelam aqueles à sua volta. Dessa forma, pode-se dizer que as narrativas brasileiras de saberes sobre infância e mídia estão produzindo uma infância mais visibilizada, ativa e participante.

O fato de esses trabalhos analisados demonstrarem a agência das crianças, entretanto, não nos permite partir para conclusões entusiastas como aquelas que as tomam como consumidores empoderados, autônomos, capazes de fazer leituras completamente independentes daquelas que o mercado propõe ao ofertar seus diversos produtos. A agência e a vulnerabilidade da criança, é preciso lembrar, são duas faces de um mesmo fenômeno que precisam ser pensadas sempre em sua complexidade e relação (MIZEN, OFOSU-KUSI, 2014). Em termos de enquadramento teórico, esses trabalhos mostram que a produção brasileira de estudos sobre mídia e infância não está vinculada ao paradigma desenvolvimentista da infância, mas a uma concepção mais recente, segundo a qual a criança é um sujeito. Nessa perspectiva, 
estão mais interessados nas negociações feitas pelas crianças por meio dos usos que elas fazem das mídias, sobretudo eletrônicas, do que nos efeitos advindos desse consumo.

\section{Considerações finais}

Com base no pressuposto de que a infância é uma narrativa da experiência da criança em um determinado contexto histórico e cultural, esse breve levantamento buscou entender, quais foram os principais discursos produzidos, na última década, sobre os primeiros anos de vida em sua relação direta com a mídia. A mídia se tornou um problema teórico para a psicologia, para a educação e para a saúde na medida em que sua relação com as crianças, a partir de uma determinada configuração histórica e cultural, gerava novos modos de ser e estar no mundo e produzia, portanto, subjetividade.

As narrativas advindas dos diferentes campos disciplinares, no entanto, não revelavam verdades dadas do que é a infância, mas carregavam em seus enunciados lutas e disputas teóricas, acadêmicas, sociais e políticas, sinalizando a produção - e não o desvelamento de suas verdades. Ao longo de quase todo o século $X X$, a psicologia se mostrou a maior autoridade em ofertar saberes sobre a infância, opondo-a constantemente à mídia, a partir da perspectiva de uma relação desigual de forças, em que a criança era retratada como passiva e inocente diante de um aparato midiático poderoso e implacável, do qual a infância precisava ser protegida, sob pena de perder-se.

As últimas décadas do século passado, todavia, foram o cenário para sucessivas rachaduras na hegemonia da psicologia, questionada pelas ciências cognitivas e pelas ciências sociais, em especial, as quais paulatinamente esmaeciam as diferenças entre adultos e crianças, do ponto de vista da falta. Os childhood studies, sem negar que a relação entre crianças e adultos é de alteridade, defendem que suas diferenças não estão naquilo que a criança ainda não é, mas nas experiências atravessadas por inúmeros elementos como classe, raça, gênero, 
formação escolar, localização geográfica etc. - diferenças socialmente produzidas e não naturais. A mudança na forma de perceber a criança incide diretamente na formulação de teorias e conceitos que permitem que ela seja pensada não só como consumidora, mas especialmente como produtora.

Tal concepção impulsionou estudos que buscaram superar a ideia do consumo midiático apenas como algo que interfere negativamente nos marcos de desenvolvimento comumente atribuídos às crianças. Em vez disso, concentraram-se em compreender como elas produziam visões de mundo específicas, sociabilidades e conteúdo que figurassem no espaço público, ampliando sua participação nas sociedades. Isso não significou dizer que o interesse pelos modos com os quais a mídia interpela a criança tenha desaparecido. Pelo contrário, os estudos de representação nos últimos anos ajudaram a questionar estereótipos e denunciar a invisibilidade de determinados grupos de crianças.

No Brasil, a ideia de dar às crianças ferramentas, no campo midiático, a fim de que, por elas mesmas, possam negociar sentidos e, assim, construírem realidade, prevalece nos estudos que fizeram parte do corpus. Entretanto, ainda há uma carência de pesquisas que levem em conta essa agência sem desconsiderar as particularidades das crianças, sobretudo de estudos que formulem, a partir da empiria, teorias que deem conta da construção social da infância no contexto brasileiro. Há também uma carência quantitativa de estudos, especialmente no campo da comunicação. O fato de ter encontrado, na amostra dos quatorze trabalhos, apenas um da área revela algo, no mínimo, sintomático.

O entendimento de que a criança não só é produto da cultura, mas produtora dela, traz a infância para o campo da comunicação não como uma temática, mas como um problema teórico. Com base nessa compreensão, surgem questões a partir das quais os investigadores da comunicação podem avançar no vasto campo interdisciplinar dos estudos da infância, tais como: de que forma a visibilização das crianças está afetando a produção da mídia? Como tratar no âmbito da infância 
a problemática produtor versus profissional de mídia? São exemplos de desafios teóricos e metodológicos que oportunizam o crescimento dos estudos de infância e mídia em sua direta e inquestionável relação.

\section{Referências}

ALCÂNTARA, Alessandra; GUEDES Brenda (Orgs.). Culturas infantis do consumo: práticas e experiências contemporâneas. São Paulo: Pimenta Cultural, 2014.

BAIOCCO, Roberto; D'ALESSIO, Maria; LAGHI, Fiorenzo. Discrepancies between Parents' and Children's Attitudes toward TV Advertising. Journal of Genetic Psychology, v. 170, n. 2, p.176-191, 2009.

BARBOSA, Antonio Carlos do Amaral. A criança e o brinquedo-TV: análise sobre o discurso publicitário direcionado para a infância na Rede Globo de Televisão. Dissertação (Mestrado) - Universidade Federal do Rio Grande do Norte, Programa de Pós-Graduação, Natal (RN), 2012.

BRAGG, Sara; BUCKINGHAM, David; RUSSELL, Rachel; WILLETT, Rebekah. Too Much, Too Soon? Children, "Sexualization" and Consumer Culture. In: Sex Education: Sexuality, Society and Learning, v. 11, n. 3, p. 279-292, 2011.

BRENT, Mawson. Technological Funds of Knowledge in Children's Play: Implications for Early Childhood Educators. Australasian Journal of Early Childhood, v. 36, n. 1, p. 30-35, 2011.

BUCKINGHAM, David. Crescer na era das mídias digitais. São Paulo: Edições Loyola, 2007.

CARRIJO, Adriana Carrijo. Significações imaginárias da infância contemporânea: mídia, pais e especialistas. Psicologia \& Sociedade, v. 24, n. 2, p. 421-429, 2012.

CASTRO, Lucia Rabello de (Org.). Infância e adolescência na cultura do consumo. Rio de Janeiro: Nau Editora, 1998 (versão pdf). Disponível em: http://nipiac.psicologia.ufrj.br/images/stories/livros/infancia e adolescencia na cultura do consumo.pdf. Acesso em: 01 de agosto de 2015.

(ed.). O futuro da infância e outros escritos. Rio de Janeiro: Faperj, Sete Letras, 2013.

CECHIN, Michelle Brugnera Cruz; SILVA, Thaise da. Assim falava Barbie: uma boneca para todos e para ninguém. Fractal, Rev. Psicologia, v. 24, n. 3, p. 623-638, 2012.

CHACÓN GORDILLO, Pedro; MORALES CARUNCHO, Xana. Infancia y medios de comunicación: El uso del método semiótico cultural como acercamiento a la cultura visual infantil. Ensayos: Revista de la Facultad de Educación de Albacete, v. 29, n. 2, p.1-17, 2014. 
CORSARO, William. The sociology of childhood. SAGE, 2011.

DEFAUW, Danielle L. 10 Writing Opportunities to "Teach to the Test". The Reading Teacher, v. 66, n. 7, p. 569-573, 2013.

DE LA ROCHE, Maritza Adelaida Lopez De La Roche. Audiências infantis, capital escolar, mídia e representações sociais. Tese de Doutorado em Educação, Instituto de Filosofia e Ciências Humanas. Unicamp, Campinas-SP, 2012.

DENOV, Myriam. Child Soldiers and Iconography: Portrayals and (Mis) Representations. Children \& Society, v. 26, n. 4, p. 280-292, 2012.

DORETTO, Juliana. Pequeno leitor de papel. São Paulo: Alameda, 2013.

ERWIN, Elizabeth J.; MORTON, Naomi. Exposure to media violence and young children with and without disabilities: Powerful opportunities for familyprofessional partnerships. Early Childhood Education Journal, v. 36, n. 2, p.105-112, 2008.

FANTIN, Monica. Crianças e games na escola: entre paisagens e práticas. Rev.latinoamericana ciencias sociales niñez juventud, $v, 13, n$. 1, p. 195-208, 2015.

FERNÁNDEZ, Almudena Ocaña Fernández; LÓPEZ, María Luisa Reyes. El imaginario sonoro de la población infantil andaluza: análisis musical de «La Banda». Comunicar, v. XVIII, n. 35, p. 193-200, 2010.

FISCHER, Rosa Maria Bueno. Pequena Miss Sunshine: para além de uma subjetividade exterior. Pro-Posições, v. 19, n. 2, p. 47-57, 2008.

FOUCAULT, Michel. Microfísica do poder. Rio de Janeiro: Graal, 1979.

FURTADO, Thaís Helena. O jornalismo infantil e o desejo de consumo: o discurso da revista Recreio. Tese (Doutorado). Universidade Federal do Rio Grande do Sul, Programa de Pós-Graduação em Comunicação e Informação. Porto Alegre-RS, 2013.

HALL, Stuart. Encoding / Decoding. In: HALL, S. HOBSON, D., LOWE, A. WILLIS, P. (eds). Culture, Media, Language: Working Papers in Cultural Studies, p. 128-138. London: Hutchinson, 1980.

DP\&A, 2005.

A identidade cultural na pós-modernidade. Rio de Janeiro:

HARVEY, Andrew. A proposal for congressionally mandated federal regulation of child-directed food and beverage television advertisements to combat childhood obesity. Health Matrix, v. 23, n. 2, p. 607-631, 2013.

HILL, Jennifer. Endangered childhoods: how consumerism is impacting child and youth identity. Media, Culture \& Society, v. 33, n. 3, p. 347-362, 2011.

HOFFMAN, Diane. Saving children, saving Haiti? Child vulnerability and narratives of the nation. Childhood, v. 19, n. 2, p.155-168, 2012 
GÓMEZ-MENDOZA, Miguel Ángel, ALZATE-PIEDRAHÍTA, María Victoria. La infancia contemporánea. Revista Latinoamericana de Ciencias Sociales, Niñez y Juventud, v. 12, n. 1, p. 77-89, 2014.

LEMISH, Dafna. Children and media: a global perspective. Malden-MA, USA: Willey Blackwell, 2015.

LENTERS, Kimberly; WINTERS, Kari-Lynn. Fracturing Writing Spaces. The Reading Teacher, v. 67, n. 3, p.227-237, 2013.

MAHER, Janemaree; FRASER, Suzanne ; WRIGHT, Jan. Framing the mother: Childhood obesity, maternal responsibility and care. Journal of Gender Studies, v. 19, n. 3, p.233-247, 2010.

MARTÍNZES, Álvaro Salas; SENDRA, Juan Menor; COROMINA, Álvaro PérezUgena. Violencia en televisión: análisis de la programación en horario infantil Violence in TV: Analysis of Children's Programming. Comunicar, v. XVIII, n. 35, p. 105-112, 2010.

MIZEN, Phil; OFOSU-KUSI,Yaw. Agência como vulnerabilidade: explicando a ida das crianças para as ruas de Acra. Linhas Críticas, v. 20, n. 41, p. 81$101,2014$.

MOLLO-BOUVIER, Suzanne. Transformação dos modos de socialização das crianças: uma abordagem sociológica. Educ. Soc., Campinas, v. 26, n. 91, p. 391-403, 2005.

MOMO, Mariangela; COSTA, Marisa Vorraber. Crianças escolares do século XXI: para se pensar uma infância pós-moderna. Cadernos de Pesquisa, v. 40, n. 141, p. 965-991, 2010.

MONTGOMERY, Kathryn C. ; CHESTER, Jeff; GRIER, Sonya A.; DORFMAN, Lori. The New Threat of Digital Marketing. Pediatric Clinics of North America, $v$. 59, n. 3, p.659-675, 2012.

O'MARA, Joanne; LAIDLAW, Linda. Living in the iWorld: Two Literacy Researchers Reflect on the Changing Texts and Literacy Practices of Childhood. English Teaching: Practice and Critique, v. 10, n. 4, p.149-159, 2011.

ORLANDI, Rosângela Orlandi. A representação social da criança em anúncios de moda na revista Vogue Kids Brasil. Dissertação (Mestrado) - Universidade de São Caetano do Sul, São Caetano do Sul (SP), 2012.

PEREIRA, Milena Gomes Coutinho Pereira. A nova face da moeda: a criança na publicidade do setor financeiro da revista Veja. Dissertação (Mestrado) UFF, Niterói-RJ, 2016.

PEREIRA, Rita Marisa Ribes. Veja estas canções: Infância e cultura de massas. Childhood \& Philosophy, n. 3, p.55-73, 2006.

POYNTZ, Stuart; HOECHSMANN, Michael. Children's Media Culture in a Digital Age. Sociology Compass, v. 5(7), p.488-498, 2011.

ROCHA, Maria Silvia Pinto de Moura Librandi da. Cenas (im)próprias para 
crianças?. Cadernos Cedes, v. 32(86), p. 97-115, 2012.

ROUSSEAU, Jean-Jacques. Emílio ou Da educação. São Paulo: Martins Fontes, [1762] 2014.

SÁNCHEZ-CARRERO, Jacqueline; SANDOVAL-ROMERO, Yamile. Keys to recognizing the levels of critical audiovisual reading in children. Comunicar, v. 19(38), p.113-120, 2012.

SALGADO, Raquel Gonçalves. From the sweet girl to the powerful hero: childhood, gender and power in the fiction and life scenes. Cadernos Cedes, v. 32(86), p.117-136, 2012.

SALGADO, Raquel Gonçalves; PEREIRA, Rita Marisa Ribes; JOBIM E SOUZA, Solange. Pela tela, pela janela: questões teóricas e práticas sobre infância e televisão. Cadernos Cedes, v. 25(65), p. 9-24, 2005.

SAMPAIO, Inês Sílvia Vitorino; CAVALCANTE, Andréa Pinheiro Paiva; ALCÂNTARA, Alessandra. Mídia de chocolate: estudos sobre a relação infância, adolescência e comunicação. Rio de Janeiro: E-papers, 2006.

SARMENTO, Manuel Jacinto. "Sociologia da Infância: Correntes e Confluências", in SARMENTO, M. J.; GOUVÊA, M. C. S. (orgS.). Estudos da Infância: educação e práticas sociais, p. 17-39. Petrópolis: Vozes, 2008.

Estudos da infância e sociedade contemporânea: desafios conceptuais.

Revista O Social em Questão, XX, n. 21, p. 15-30, 2009.

SCHNEIDER, Jenifer Jasinski; KOZDRAS, Deborah; WOLKENHAUER, Nathan; ARIAS, Lisa. Environmental E-Books and Green Goals. Journal of Adolescent \& Adult Literacy, v. 57, n. 7, p. 549-564, 2014.

SIMPSON, Brian. Challenging childhood, challenging children: Children's rights and sexting. Sexualities, v. 16, n. 5-6, p. 690-709, 2013.

SIQUEIRA, Isabelle Borges; WIGGERS, Ingrid Dittrich; SOUZA, Valéria Pereira De. O brincar na escola: a relação entre o lúdico e a mídia no universo infantil. Revista Brasileira de Ciências do Esporte, v. 34, n. 2, p. 313-326, 2012.

SIROTA, Régine. Emergência de uma sociologia da infância: evolução do objeto e do olhar. Cadernos de Pesquisa, v. 112, n. 2, p. 7-31, 2001.

SOBRAL, Jacqueline. Você gosta de alguém? Representações de amor, erotismo e sexo construídas por crianças em contextos populares a partir da cultura midiática. Dissertação (Mestrado), Escola Superior de Propaganda e Marketing, São Paulo-SP, 2014.

SODRÉ, Muniz. Antropológica do espelho: uma teoria da comunicação linear e em rede. Petrópolis: Editora Vozes, 2012.

STEARNS, Peter. A infância. São Paulo: Contexto (Coleção história mundial), 2006.

THOMPSON, Kirrilly. Because looks can be deceiving: Media alarm and the 
sexualisation of childhood - do we know what we mean? Journal of Gender Studies, December 2010, Vol. 19(4), p. 395-400.

TOMAZ, Renata. A invenção dos tweens: juventude, cultura e mídia. Intercom, Rev. Brasileira de Ciências da Comunicação, v. 37, n. 2, p. 177-202, 2014.

TOMAZ, Renata de Oliveira. Da negação da infância à invenção dos tweens: imperativos de autonomia na sociedade contemporânea. Dissertação (Mestrado em Comunicação e Cultura), Escola de Comunicação, Universidade Federal do Rio de Janeiro, Rio de Janeiro, RJ, 2011.

TRICE, Ashton D. Sensation-seeking and video choice in second grade children. Personality and Individual Differences, v. 49, n. 8, p.1007-1010, 2010.

VERGARA, Enrique; VERGARA, Ana. Representation of childhood in advertising discourse in Chile. Comunicar, v. 19, n. 38, p.167-173, 2012.

VIVARTA, Veet (Coord.). Infância e Consumo: estudos no campo da comunicação. Brasília: ANDI; Instituto Alana, 2009.

WARDE, Mirian Jorge. G. Stanley Hall e o child study: Estados Unidos de fins do século XIX e começo do século XX. Rev. Bras. Hist. Educ., v. 14, n. 2 (35), p. 243-270, 2014.

WELLS, Karen. Narratives of liberation and narratives of innocent suffering: the rhetorical uses of images of Iraqi children in the British press. Visual Communication, v. 6, n. 1, p. 55-71, 2007.

WOHLWEND, Karen E. The Boys Who Would Be Princesses: Playing with Gender Identity Intertexts in Disney Princess Transmedia. Gender and Education, v. 24, n. 6, p.593-610, 2012.

YOUNG, Chase; RASINSKI, Timothy V. Student-Produced Movies as a Medium for Literacy Development. The Reading Teacher, v. 66, n. 8, p.670-675, 2013.

YU, Jay Hyunjae. Mothers' perceptions of the negative impact on TV food ads on children's food choices. Appetite, v. 59, n. 2, p.372-37, 2012.

ZIVKOVIC, Tanya; WARIN, Megan; DAVIES, Michael; MOORE, Vivienne. In the name of the child: The gendered politics of childhood obesity. Journal of Sociology, v. 46, n. 4, p.375-392, 2010. 